\title{
Przedsiębiorczość w teorii i badaniach Perspektywa młodych badaczy
}





\section{Przedsiębiorczość w teorii i badaniach \\ Perspektywa młodych badaczy}

redakcja naukowa

Agnieszka Postuła, Marcin Darecki 
Recenzenci:

dr hab. Tomasz Bernat, prof. US

dr Agnieszka Brzozowska

dr Rafał Cieślik

Denis Frydrych, Ph.D.

dr Renata Gabryelczyk

dr Marek Gnusowski

dr Waldemar Grzywacz

prof. Juan J. Jiménez-Moreno

dr Magdalena Klimczuk-Kochańska

dr Magdalena Marczewska

dr Oskar Szumski

dr hab. Jacek Pasieczny

dr Anna Pawłowska

dr hab. Igor Postuła

dr hab. Marta Postuła

dr Tomasz Rosiak

dr hab. Robert Wolański

Redakcja

Anita Sosnowska

Projekt okładki

Paulina Popławska

(C) Copyright by Wydawnictwo Naukowe Wydziału Zarządzania Uniwersytetu Warszawskiego, Warszawa 2017

ISBN 978-83-65402-57-8

e-ISBN 978-83-65402-58-5

http://dx.doi.org/10.7172/978-83-65402-58-5.2017.wwz.3

Druk i oprawa: ZGUW. Zam. 1494/16 


\section{Spis treści}

Wprowadzenie (Agnieszka Postuła, Marcin Darecki) . . . . . . . . . . 7

\section{Część I. O ludziach}

Anita Richert-Kaźmierska, Alicja Polańska - Entrepreneurship after the Age of Sixty-Five? Reflections of Third Age University students . . . . . . . . 13

Anna Dolot - The Observed and Expected Behavior of Immediate

Superiors: The Employees' Perspective. . . . . . . . . . . . . . . . . . 27

Marta Kabut, Mateusz Kabut - Different Faces of Motivation in a Research Institute - A Case Study . . . . . . . . . . . . . . . . . . . 42

Andżelika Dzięgiel, Patrycja Gulak-Lipka - Development of Entrepreneurial Qualities of Athletes in Selected Sport Disciplines . . . . . . . . . . . . . . 59

\section{Część II. O systemach}

Luigi Lai - EU Insolvency Regulations: New Tendencies Fostering

Entrepreneurship in Europe . . . . . . . . . . . . . . . . . . . 79

Sirojiddin Orifov - SME Development, Economic Growth and State Itervention in a Developing Economy: The Uzbek Story . . . . . . . . . . . 96

Sabina Grižančič - Launch Strategy in Crowdfunded NVTs: Exploring Storytelling . . . . . . . . . . . . . . . . . . . . . 120

Małgorzata Oleś - Economic Benefits Stemming from the Implementation of Business Process Management and Business Process Model and Notation .

\section{Część III. Polski kontekst}

Olga Irodenko - Czynniki efektywności audytu wewnętrznego jako istotnego elementu zarzadzania przedsiębiorstwem - badanie teoretyczne. . . 147 Adam Czarnota - Analiza przedsiębiorstw zaawansowanych technologii w województwie zachodniopomorskim . . . . . . . . . . . 163 Joanna Chlebiej - Wizerunek branży farmaceutycznej w polskim Internecie . 183 



\section{Wprowadzenie}

Monografia, którą przekazujemy w Państwa ręce jest publikacją złożoną, ukazującą wielowątkowość zagadnienia, jakim jest przedsiębiorczość. Przedstawione zostały $\mathrm{w}$ niej zarówno kwestie związane z ludźmi, ich zachowaniami, postawami, jak i uwarunkowania finansowe ekonomiczne, systemowe i strategiczne, nierozerwalnie łączone z przedsiębiorczością. Przede wszystkim prezentuje ona podejście młodych badaczy - perspektywę doktorantów, których spojrzenie na przedsiębiorczość jest świeże i aktualne. Teksty dotyczą tematów starszych, ale wciąż ważkich dla nauk o przedsiębiorczości, ale też zjawisk nowych, nie do końca jeszcze wyeksplorowanych i opisanych. Poszczególne rozdziały odzwierciedlają popularne tematy $\mathrm{w}$ nauce, jak również polski lokalny kontekst przedsiębiorczości. Wszystko to wynika $\mathrm{z}$ różnorodności, jaką niesie w sobie ta dziedzina biznesu, a zarazem nauki, i moc sprawcza, którą rozpoznają wszystkie silne gospodarki światowe (Isenberg, 2010). Zdefiniowane zostały już czynniki sukcesu wchodzące w skład przedsiębiorczych kompetencji, jednak na podstawie tych kategorii nie udało się osiągnąć znaczących sukcesów. Wynika to $\mathrm{z}$ faktu, że oblicza przedsiębiorczości zmieniają się na całym świecie w niezwykłym tempie i ciężko jest formułować skuteczne reguły w tradycyjnym wymiarze (Postuła i in., 2014). Dobre praktyki, warte naśladowania, ujawniają się w różnych krajach i kontekstach jednocześnie. Cenne lekcje można pobierać z szybko rozwijającej się praktyki, gdyż budowanie i wymyślanie jej od podstaw nie przynosi zadowalających rezultatów. Zaczynamy powoli zdawać sobie sprawę, że najskuteczniejszym podejściem tworzenia ekonomii przedsiębiorczej jest śledzenie - nawet tej niedoskonałej - praktyki. Dla zbudowania sprawnego przedsiębiorczego ekosystemu liderzy biznesu powinni postępować według określonych zasad (Feld, 2012). Wśród nich można wymienić dbałość o wszystkie istotne elementy tego ekosystemu, np. przywództwo, kulturę, rynki kapitałowe czy klientów o otwartych umysłach, które wzajemnie na siebie oddziałują w różnych konfiguracjach, a bez 
siebie wzajemnie nie istnieją. Tym różnym składowym przedsiębiorczego ekosystemu poświęcamy niniejszą monografię.

W pierwszym z jedenastu rozdziałów Anita Richert-Kaźmierska i Alicja Polańska opisały objawy zachowań przedsiębiorczych w przypadku osób, które przekroczyły 65 rok życia. Wskazane zostały istotne elementy skoncentrowane na aktywizacji osób starszych. W tekście, szczególny nacisk położono na aktywność społeczną i edukacyjną. Autorki podkreśliły, że obszary te stanowią zaledwie wycinek całej szerokiej grupy zachowań przedsiębiorczych w kontekście osób starszych.

Drugi rozdział poświęcono znaczeniu i roli bezpośrednich przełożonych, w tym ich zachowaniu, w kontekście zarządzania zasobami ludzkimi. Szeroka analiza przeprowadzona przez Annę Dolot umożliwiła zdefiniowanie zadan, które powinny być realizowane przez przełożonych podczas zarządzania zespołem pracowników. Kluczową część tekstu stanowi prezentacja wyników badań wykazujących, z jednej strony, zaobserwowane, z drugiej zaś oczekiwane przez pracowników zachowania osób zarządzających. Wnioski z przedstawionych badań mogą stanowić cenne wskazówki dla praktyków odpowiedzialnych za zarządzanie zasobami ludzkimi.

Kolejny, trzeci rozdział autorstwa Marty Kabut i Mateusza Kabuta dotyczy zarządzania i motywowania pracowników naukowych. Poza analizą literatury, autorzy przeprowadzili badania potwierdzające dotychczasowe opracowania dotyczące motywacji tejże grupy. Jednym z ważniejszych, podkreślanych w tekście czynników mających wpływ na pracę naukową są ciekawość badawcza oraz wewnętrzna motywacja poszczególnych osób. Jak zostało przedstawione przez autorów, zaskakująca była niezwykle wysoka pozycja atmosfery w pracy, oddziałująca na poziom motywacji jednostek. Szczególną uwagę w tekście poświęcono także potrzebom i oczekiwaniom doktorantów.

Następna część niniejszej publikacji dotyczy postaw przedsiębiorczych w grupie sportowców, które zgłębiała Partycja Gulak-Lipka. W badaniu, prowadzonym przede wszystkim z perspektywy pracodawcy, skoncentrowano się na osobach uprawiających sporty indywidualne - lekkoatletykę oraz sporty zespołowe - koszykówkę. Wyniki analiz wskazują na inny rozkład cech przedsiębiorczych prezentowany przez obie z grup. Przykładem omawianych różnic są predyspozycje do zakładania własnych działalności. W tym przypadku osoby uprawiające sporty indywidualne znacznie częściej decydują się na ten krok w swojej karierze zawodowej. Dodatkowo autorzy wskazują, iż sukcesy w sporcie niejednokrotnie przekładają się na sukcesy w działalności jako przedsiębiorca.

Kolejne artykuły przybliżają czytelnikom aspekty o charakterze prawnym, ekonomicznym i finansowym w przedsiębiorczości. W rozdziale 
piątym Luigi Lai odniósł się do zagadnień niewypłacalności przedsiębiorstw pod kątem ekonomicznym oraz prawnym, w szczególności z zakresu prawa upadłościowego. Wskazana została możliwość powstania nowego pokolenia „świadomych przedsiębiorców”, którzy będą korzystać z możliwości wynikających $\mathrm{z}$ „teorii drugich szans”. W następnym z tekstów Sirojiddin Orifov skoncentrował się na związku pomiędzy wzrostem gospodarczym, rozwojem MŚP a wsparciem rządowym. Do analizy wybrany został jeden z postkomunistycznych krajów - Uzbekistan, którego cechą charakterystyczną było podjęcie decyzji o stopniowym przechodzeniu z gospodarki centralnie planowanej do wolnorynkowej. Ostatni z tej grupy rozdział - autorstwa Sabiny Grižančič - poświęcono inicjatywom crowdfundingowym jako strategicznym metodom przyciągania kapitału w celu rozwoju produktów firm. W tekście przedstawione zostały teoretyczne podstawy przyszłych badań dotyczących fenomenu tzw. storytellingu i narracji wiążącej się bezpośrednio $\mathrm{z}$ crowdfunginiem.

Rozdział ósmy, Małgorzaty Oleś, dotyczy zagadnień systemowych. Traktuje on o konieczności tworzenia coraz to bardziej dopasowanych systemów i procesów mających na celu minimalizację klasycznej biurokracji. Celem tworzonych narzędzi jest ułatwienie pracy i działania wszystkim ich użytkownikom. W opracowaniu przedstawiono korzyści wynikające ze stosowania scharakteryzowanych systemów informatycznych.

W następnym z tekstów opisano czynniki mające wpływ na efektywność funkcjonowania audytu wewnętrznego w przedsiębiorstwach. Rozdział Olgi Irodenko, składający się z trzech części, opisuje odpowiednio genezę i rozwój audytu wewnętrznego jako nowoczesnego instrumentu zarządzania przedsiębiorstwem. Następnie zostaje on przedstawiony na tle dorobku nauk o zarządzaniu. Ostatnia z części opracowania dotyczy natomiast efektywności funkcjonowania komórki audytu wewnętrznego w przedsiębiorstwach.

Rozdział dziesiąty - Adama Czarnoty - poświęcono analizie przedsiębiorstw zajmujących się zaawansowanymi technologiami. Firmy te, cieszą się obecnie dużym zainteresowaniem zarówno naukowców, publicystów, jak i polityków gospodarczych. W artykule przeanalizowano sektor high-tech województwa zachodniopomorskiego. Zidentyfikowano oraz scharakteryzowano najsilniejsze cechy wyróżniające przedsiębiorstwa wysokiej techniki.

Ostatni z tekstów, autorstwa Joanny Chlebiej, dotyczy wizerunku branży farmaceutycznej w Internecie. Wybór przez autorkę wskazanej branży nie był przypadkowy. Jak zostało wskazane, wynika to przede wszystkim z jej specyfiki, gdzie każda pojawiająca się publicznie informacja bezpośrednio przekłada się na wizerunek całej branży, nie zaś konkretnych przedsiębiorstw. Jak wskazała autorka, związane jest to z brakiem rozpoznawalności koncernów produkujących leki i traktowaniem wszystkich na równi. Konsumenci kierują 
się stereotypami dotyczącymi całej branży, a zarówno zasługi, jak i przewinienia poszczególnych reprezentantów branży farmaceutycznej mogą przysłaniać wszelkie inne, kluczowe informacje oraz kontekst danej sytuacji.

Wieloaspektowość niniejszej monografii sprawia, iż jest ona uniwersalna i może być źródłem inspiracji i wiedzy zarówno dla pracowników naukowych, studentów, jak i dla praktyków biznesowych. Mamy nadzieję, że dla wszystkich Czytelników niniejsze opracowanie stanowić będzie ważne uzupełnienie własnych zasobów książkowych.

Agnieszka Postuła Marcin Darecki

\section{Literatura}

Feld, B. (2012). Startup communities: Building an entrepreneurial ecosystem in your city. John Wiley \& Sons.

Isenberg, D. (2010). How to Start an Entrepreneurial Revolution. Harvard Business Review, June, 1-12.

Postuła, A., Glinka, B. i Pasieczny, J. (red.). (2014). Oblicza przedsiębiorczości. Warszawa: Wydawnictwo Naukowe WZ UW. 
Część I

O ludziach 



\title{
Anita Richert-Kaźmierska* Alicja Polańska**
}

\section{Entrepreneurship after the Age of Sixty-Five? Reflections of Third Age University students}

\begin{abstract}
I am glad that I am creative. It is worthwhile to learn all of one's life, as long as, as they say, the legs still want to carry you, the eyes see, and the ears hear. Let's meet others, talk with each other, learn from one another, and be creative. For sure, this will mean a better old age. (Barbara, aged 69)
\end{abstract}

The common synonyms for entrepreneurship usually include such concepts as creativity, innovation, and activity. These, in turn, are more often associated with youth rather than people of older age (Górniak, 2013).

On the basis of literature research and interviews conducted with students from the Sopot School of Social Psychology of the University of the Third Age, the authors determined that among individuals aged over 65 entrepreneurship usually manifests itself differently than in its classical understanding, i.e. running and managing an enterprise. It tends to mean broadly understood social and educational activity.

Keywords: entrepreneurship, entrepreneurial behavior, activity in the older age, University of the Third Age.

\section{Jak wygląda przedsiębiorczość po 65. roku życia? Refleksje słuchaczy uniwersytetu trzeciego wieku}

Za synonimy przedsiębiorczości uważa się pojęcia, takie jak: twórczość, innowacyjność oraz aktywność i są one na ogół łączone bardziej z młodością niż z osobami starszymi (Górniak, 2013).

Na podstawie badań literaturowych oraz wywiadów przeprowadzonych ze studentami Psychologicznego Uniwersytetu Trzeciego Wieku działającego przy Wydziale Zamiejscowym

* Anita Richert-Kaźmierska, Ph.D., Eng. - Faculty of Management and Economics, Gdańsk University of Technology; ul. G. Narutowicza 11/12, 80-233 Gdańsk; e-mail: Anita. Richert@zie.pg.gda.pl.

* Alicja Polańska, M.A. candidate in Management - Faculty of Management and Economics, Gdańsk University of Technology; ul. G. Narutowicza 11/12, 80-233 Gdańsk; e-mail: alipolan@interia.pl. 
w Sopocie Uniwersytetu SWPS autorki ustaliły, że wśród osób w wieku powyżej 65 lat przedsiębiorczość manifestuje się inaczej, niż jej klasyczne rozumienie związane z zarządzaniem przedsiębiorstwem. Oznacza raczej szeroko rozumianą działalność społeczną i edukacyjną.

Słowa kluczowe: przedsiębiorczość, zachowania przedsiębiorcze, aktywność osób starszych, uniwersytet trzeciego wieku.

JEL: L26, J11, J14, 129

\section{Introduction}

Although the term entrepreneurship is very common in the subject matter covered by the relevant literature, it has not been defined in an unequivocal way (Kraśnicka, 2002, p. 74; Matusiak, 2006, pp. 97-100). Depending on whether the term is used by a specialist in economics, management, law, psychology, or other fields and disciplines, entrepreneurship is attributed different meanings.

Colloquially, entrepreneurship is associated with running one's own small business (Piasecki, 1998; Janczewski, 2006). In the literature, it is usually defined as a set of attributes and skills making it possible for an individual or organization to achieve objectives efficiently and effectively-a personality-oriented approach (Sudoł, 2008, p. 11). It is also considered as being specific, proactive behavior-a behavioral approach (Shapero and Sokol, 1982; Dyer, 1994). According to a thesaurus (Kurzowa, Kubisz-Mędrala, Skarżyński, and Winiarska, 2016), entrepreneurship is the same as creativity, activity, and innovation.

Due to the specific nature of entrepreneurship and its link with dynamic and creative (innovative) action, it tends to be associated with youth rather than with older people, where the oldest individuals are a particularly excluded group. Although, as Leon Knabit, an eighty-six-year-old father, argues, "youth is a state of mind" (2016), the elderly are viewed by society through the prism of their chronological (calendar) age as being less efficient and less productive, slower in performing tasks, needing more time to make decisions, less willing to take risks, and having difficulties in accepting novelties (Richert-Kaźmierska, 2013). It is difficult to find references to entrepreneurship with such a stereotype of an older person functioning in Polish society (Szukalski, 2004; Miszczak, 2006).

Meanwhile, the activity and entrepreneurship of senior citizens, in the face of an ageing population, are becoming important and current topics. In the literature on the subject, more and more attention is paid to the role of senior entrepreneurs in the economy (Kautonen, Tornikoski, and Kibler, 
2011), inclusive entrepreneurship ensuring the social inclusion of senior citizens (Wach, 2015), the social productivity of senior citizens (Szukalski and Szatur-Jaworska, 2014), and the social and educational activity of the elderly as a way to maintain a high quality of life in old age (Halicka, 2004).

This article refers to only a narrow slice of issues related to the activity and entrepreneurship of the elderly. The authors focused on the social and educational activities of seniors as forms of entrepreneurial behavior in old age. In order to describe entrepreneurship by senior citizens in this sense, the results of the literature analysis and interviews conducted among students of the Sopot School of Social Psychology of the University of the Third Age were used.

\section{Entrepreneurship after the Age of Sixty-Five}

Young people are stereotypically seen as being more entrepreneurial then the elderly (Wasilczuk, 2014). The results of studies that investigated the relationship between a subjects' age and their entrepreneurship (creativity and innovativeness) were not unequivocal, however (Levesque and Minniti, 2001; Gielnik, Zacher and Frese, 2012). Reasoning in this area is hindered by the ambiguity of the idea of entrepreneurship and the capacity of the concept of "older people" as used in the literature.

Researchers point to age-related deterioration of people's physical and mental condition, including creative efficiency (Trypka, 2008; Erikson, 2004).

At the same time, the literature describes cases of activity and entrepreneurship by people of advanced age-the creators, ${ }^{1}$ individuals undertaking extraordinary challenges, ${ }^{2}$ and the leaders of the world's largest companies $^{3}$ (Sherman, 2015). The activities and entrepreneurship of the elderly are fostered by positive emotions, free of elements of disapproval, anxiety, and tension (Małyska, 2015). Creation is motivated by a sense of satisfaction caused by the performed activity and its direct cognitive consequences (Kocowski and Turner, 1991, p. 81). It is also fuelled by the need to repair and improve reality (Partyka, 1999, p. 41).

1 Hendrik Groen, the author of the bestseller Small Experiments with Happiness: Secret Diary of Hendrik Groen, Aged 83 and $1 / 4$.

2 Seventy-year-old Aleksander Doba, National Geographic Traveller of the Year 2015.

3 The five oldest CEOs on the Fortune 500 list in 2015 were Warren Buffett (aged 85, Berkshire Hathaway), Sheldon Adelson (aged 81, Las Vegas Sands), Roger Penske (aged 78, Penske Automotive Group), Leslie Wexner (aged 78, L Brands), and Alan Miller (aged 77, Universal Health Services). 
In literature on the subject, the discourse on the entrepreneurship of seniors usually relates it to the starting and running businesses by the elderly (Kautonen, Tornikoski, and Kibler, 2011; Wach, 2015). The term elderly in this case most frequently covers individuals of "immobile" productive age ${ }^{4}$ or persons of near-retirement age. ${ }^{5}$

It has to be noted, however, that when considering individuals aged 65 years and over the concept of "entrepreneurship" cannot be associated with only business or professional activity. It may take on the form of activity and creativity related to organizing leisure time or performing socially useful tasks (Szukalski and Szatur-Jaworska, 2014). In relation to this group it seems appropriate to accept an understanding of entrepreneurship as proposed by Gruszewska (2014). This author defines entrepreneurship as a human trait that is manifested in people's relationship to the environment or as an attitude towards the outside world expressed in taking up various forms of activity.

The justification for such an understanding of entrepreneurship in the case of seniors (aged 65 and over) is also provided by the results of research on engaging already professionally inactive seniors in social and educational projects (Halicka, 2004). They indicate that in this group the motives for participation in such projects are similar to those of individuals deciding to start their own business (Stephan, Hart, and Drews, 2015). These include the need for achievement and self-fulfillment, independence, maintaining or improving social status, lack of satisfaction with the current status quo, or the stimulating influence of the environment.

The shaping of entrepreneurial behaviors and attitudes requires appropriate reinforcement throughout a person's life. This process is by far the most difficult to carry out in the advanced stages of the human life cycle, especially if the individual has already resigned from professional activity (Strojny, 2007).

Polish Universities of the Third Age are institutions that strive to strengthen the entrepreneurial attitude and behavior of senior citizens. ${ }^{6}$ They also play an important role in the promotion and implementation of the concept of active ageing and contribute to the development of local entrepreneurship (Hasińska and Tracz 2016). According to Klimczuk (2013),

4 In Poland, according to the GUS Central Statistical Office of Poland, immobile age is the age from 45 to 59 years for women and from 45 to 64 years for men.

5 The near-retirement age is defined for women as the period from 50 to 65 years of age, while for men as the period from 55 to 70 years of age, Dezaktywacja osób w wieku okołoemerytalnym [The deactivation of people of near-retirement age], 2008.

6 As of November 2015, there were 464 Universities of the Third Age active in Poland. (Uniwersytety trzeciego wieku [Universities of the third age], 2016, p. 2). 
the role of Universities of the Third Age in the area of entrepreneurship development will increase over time. They will not only affect the development of individual entrepreneurship among their students, but also impact entrepreneurship and innovation in the economy as a whole.

\section{Research Method}

The survey was conducted among the students of the University of the Third Age of the Sopot School of Social Psychology (UTWSSPS) in the period from March to April of 2016. ${ }^{7}$ The study used two research methods: participant observation and the anthropological interview.

Use of the participant observation method was aimed at enabling the achievement of two goals. Firstly, the verification of the claim that participation in classes offered by UTWSSPS leads to the activation, social inclusion, and entrepreneurial mobilization of its students. Secondly, building trust between the researchers and the students of the UTWSSPS, so that carrying out an anthropological interview with their participation would be possible in the second stage of the study.

In March and April of 2016 one of the authors, with the knowledge and consent of UTWSSPS students, participated with them in Gymnastics of the Mind, Creative Photography, and Dance Therapy classes. Within the framework of these courses, the author performed all tasks as assigned by the professors, like the remaining students. Many tasks were implemented in pairs or groups, which also affected building the relationship between the author and the rest of the course participants.

The interview was conducted with seven UTWSSPS students, including six women and one man. All of them were retirees aged 62 to 76 . The study participants were chosen so that their demographic characteristics reflected the specifics of the population of students of Universities of the Third Age (UTA) in Poland. ${ }^{8}$ The participants of the study were reached through involvement in UTWSSPS classes and what is known as the "snowball" effect-recommendations of subsequent interviewees.

As to the specificity of the anthropological interview, it was open, i.e.

7 The research was conducted as a part of semester project entitled "Entrepreneurship of the Elderly" at the Faculty of Management and Economics of the Gdansk University of Technology.

8 According to the GUS Central Statistical Office of Poland, the largest groups of UTA students in Poland are women (86\%), retirees (96\%), and sexagenarians (59.7\%) (Uniwersytety trzeciego wieku [Universities of the third age], 2016). 
unstructured and non-standardized (Konecki, 2000; Kostera 2003; Silverman 2009; Sztumski, 1995; Frankfort-Nachmias and Nachmias, 2001). Although each of the talks focused on the main issues meeting the objectives of the study, each of the interviews was different. New threads cropped up every now and again during the conversation. This was a result of expanding on statements made by some of the interviewees. The conversations were held in an environment known to the participants of the study (in four cases in the university cafeteria and in the other two in the homes of the respondents). The duration of each of the talks never exceeded one hour.

Only partial results of the interview are presented below due to the limited scope of this article. The results relate to methods of defining entrepreneurship, the determinants of active ageing, and opportunities to acquire and develop qualities and entrepreneurial skills by the elderly. With the consent of the study participants, this article uses their own words as given during the talks with the authors.

\section{Survey Results}

UTWSSPS Students about the Importance of the Concept of Entrepreneurship The meaning of the concept of entrepreneurship was systematized into three categories on the basis of views expressed during the interviews by UTWSSPS students:

- Entrepreneurship as a synonym for the concept of creativity,

- Entrepreneurship as a set of attributes and skills that enable people to develop themselves, and

- Entrepreneurship as a personal way of life.

Some of study participants used the concept of creativity and entrepreneurship interchangeably while talking about entrepreneurship. Both entrepreneurship and creativity were understood as having ideas, the ability to plan activities as well as the readiness and determination to implement plans. It also encompassed flexible adaptation to new circumstances. The participants of the study stressed the importance of such entrepreneurship in the daily lives of the elderly as helping to get out of routine and stereotypes. They pointed to the importance of determination in implementing their ideas and activities, and following their plans.

Entrepreneurship is the ability to schedule time. I try to live more slowly now, but you need to know what time your bus leaves or when to make an appointment with a doctor in order to avoid a wait, for example. Creativity and entrepre- 
neurship might not be exactly the same, but personally I would say that they are very similar. (Małgorzata B., aged 62)

Entrepreneurship is the ability to obtain the resources one needs to satisfy one's needs. (...) Planning all actions ahead and adjusting to the situation when something pops up as well as a willingness to change. (Zuzanna, aged 68)

In some of the statements made, entrepreneurship was associated with a set of attributes and skills that enable people to develop themselves. Among the traits belonging to widely-understood entrepreneurship, interview participants most frequently cited confidence and belief in oneself (intrinsic motivation), while among skills they forwarded openness to others and readiness to cooperate with them. In almost every interview, entrepreneurship and skills or aptitudes were identified with this concept and indicated as a prerequisite for success, personal and/or professional.

Knowledge, self-confidence, good interpersonal and communication skills (...). An enterprising person should not be overbearing, such a person should be feisty. They should be able to push to achieve what they want. (Małgorzata W., aged 68) Desire. They must be willing and bold. If you don't want to learn, there is no person in the world who can teach you effectively. Courage, wide field of view, sincerity and boldness are the most important traits. (Małgorzata B., aged 62) In short, where there is a will, there is a way. If I want to, I can do anything. If you are closed, stifled, and curled up, not much can be done with you. You need somebody to approach and open you. This requires a lot of work. As for traits, I would pay attention to pugnacity and joy - the ability to feel it no matter what you do, a sense of satisfaction, openness. (Zuzanna, aged 68)

Finally, while answering the questions, "What is entrepreneurship for you?" and "How would you define this concept?" the interviewees observed that entrepreneurship is the "original" way of life, based on the consistent following "one's own path." They added that usually, entrepreneurship understood this way requires overcoming many obstacles, determination, and consistency in action, but allows a person to be free and dependent only on his or her own decisions, a form of "remuneration."

"Anyone can be the owner of a business: Let's take matters into our own hands," was a popular slogan at one time. I took matters into my own hands during the systemic transformation and started an advertising studio. (...) Despite the objections of the surroundings, I decided to take the step. Self-employment in a studio was faster and I could use creative designs and handmade signs there, which was shocking in those years. (Czesław, aged 63)

I liked and appreciated fashionable things, once. I followed people to a point where I realized that now it is my time. (...) By choosing physical activities at the UTA, I have set an example for my friends and family and I have showed that 
a person of my age and health status can do something. (Barbara K., aged 63) Entrepreneurship makes possible the getting out of a difficult situation or even transforming failure into success. An enterprising person thinks out-of-the-box and provides custom solutions. (Barbara P., aged 69)

\section{What Affects the Activity and Entrepreneurial Behaviors of the Study Participants?}

During discussions with UTWSSPS students, issues concerning factors influencing the activity and entrepreneurship of the elderly were among those signaled. According to an interviewee, individual traits and curiosity about the world as well as about the environment in which one operates can be considered significant. Numerous respondents claimed that age does not matter. The UTWSSPS students pointed out that their activity is highly influenced by participation in creative activities offered at the University of the Third Age.

Table No. 1. Factors Affecting the Retention of Activity and Entrepreneurship: Featured Reviews of Interview Participants

\begin{tabular}{|c|c|}
\hline Individual traits & $\begin{array}{l}\text { You are born entrepreneurial, either you have the skills or you } \\
\text { don't. (...) It may happen that a talented footballer is a poor head } \\
\text { of a sports club. If we have that creativity deep inside, it may be } \\
\text { recovered. (Czesław, aged 63) } \\
\text { Curiosity towards the world, curiosity towards people, and faith } \\
\text { in one's ideas drive all this power and energy (...) When you think } \\
\text { about something, you do it in due course even though it requires } \\
\text { a lot of work. (Czesław, aged 63) } \\
\text { Openness and courage. Appreciating what you have through a sense } \\
\text { of satisfaction from your achievements. (Elwira, aged 76) }\end{array}$ \\
\hline $\begin{array}{l}\text { The environment in } \\
\text { which one operates }\end{array}$ & $\begin{array}{l}\text { Entrepreneurship is affected by everything. Maybe even by the } \\
\text { climate. (Małgorzata W., aged 68) } \\
\text { Choosing the right company or guru (...), encouraging other peo- } \\
\text { ple to take action and be creative, and reading-maybe not profes- } \\
\text { sional things, but something from popular science. (Małgorzata } \\
\text { W., aged 68) }\end{array}$ \\
\hline $\begin{array}{l}\text { Participation in } \\
\text { UTWSSPS classes }\end{array}$ & $\begin{array}{l}\text { At the University of the Third Age, we have classes with Przemek, } \\
\text { who is a psychologist and has been teaching us creativity for some- } \\
\text { thing like two years, now. Many people were able to transform } \\
\text { their thinking under the influence of our conversations and exer- } \\
\text { cises. (Barbara P., aged 69) }\end{array}$ \\
\hline
\end{tabular}

Source: Own work. 


\section{Participation in University of the Third Age Classes and the Activation of Older People / Promotion of Entrepreneurial Behavior}

The study also collected opinions on the role played by Universities of the Third Age in activating the elderly.

The interviewees referred to their experience and cited examples of the positive impact of participation in classes at Universities of the Third Age on the lives of their friends. They pointed out that being a UTA student acts as a stimulus to networking and taking steps related to personal development as well as triggering creativity (by becoming free of fear of criticism).

You can and you must learn to be creative if you want to be fully active in your environment. A great example of this is classes at the University of the Third Age, where we learn such creativity from the beginning, and, as if that weren't enough, we're watching each other doing different things. It all starts to develop your mind. You see new things and as a result a wave of new ideas emerges. (Zuzanna, aged 68)

Remember, what is not prohibited, is allowed. You are limiting yourself to some concept in situations when you have to get out of that framework, if not through the door then through the window. Creativity is also useful to me in photography classes. There, we get assignments such as photographing hands, an eye, or a phone, for example. The ways to accomplish this are completely different and often not at all obvious. (Barbara P., aged 69)

My interest in photography was dictated by necessity. My son played soccer and I wanted to immortalize his achievements. I very much liked the idea of photography workshops at the University of the Third Age as it is often difficult to show things in a picture in the desired way. I wanted to learn how to do this because of the sports photography, but I learned a lot more. (Czesław, aged 63)

Often during conversations at the beginning of the interview the participants argued that entrepreneurship cannot be learned in old age. However, a few moments later, when they talked about their participation in the activities of the University of the Third Age, they reflected on how much they changed their way of life and their approach to many issues in recent months or years. They concluded that they had become more active and more enterprising. They adjusted their earlier statements and recognized that even in old age "it [the level of activity and entrepreneurship - authors" comment] can change." In the case of all interviewees, participation in the creative classes offered by the UTWSSPS was a door to a "new world"-a new way to spend leisure time actively and with people of a similar age. 


\section{Summary}

This article discusses the problems of activity and entrepreneurship in the case of the elderly. It is based on the results of a survey conducted among students of the University of the Third Age at the Sopot School of Social Psychology.

The authors found that the respondents-the elderly-define entrepreneurship in three categories: as a synonym for the concept of creativity, as the equivalent of a set of qualities and skills allowing people to develop, and as one's "own" way of life. On the one hand, the proposed definitions of entrepreneurship presented by the interviewees fit into the canon of definitions present in the literature covering the subject-matter, while on the other hand, they go beyond the stereotypical perception of entrepreneurial activity as the activity of and entrepreneur associated with running a business. For older people, entrepreneurship is first and foremost an activity and the ability to implement plans in daily life in relation to leisure time and social activity.

While talking about the factors determining the activity and entrepreneurship of the elderly, the respondents most frequently referred to individual characteristics and favorable environmental conditions. In this regard, the responses obtained correspond fully with the existing scientific output contained in the literature on this subject-matter.

An interesting result of the study related to the participation of the respondents in the activities of the University of the Third Age and its impact on the development of their personal activity and entrepreneurship (compare with Table No. 2).

Table No. 2. Participation in UTWSSPS Classes and the Activity and Entrepreneurship of Respondents

\begin{tabular}{|l|l|}
\hline \multicolumn{1}{|c|}{ Respondent } & \multicolumn{1}{c|}{ What do you get out of participation in UTWSSPS classes? } \\
\hline Barbara, aged 63 & $\begin{array}{l}\text { It allows me to contact other people and learn from them without } \\
\text { being criticized and without any attempts at changing me forcibly. } \\
\text { It is also a place that facilitates the exchanging of opinions on } \\
\text { topics not related to the course itself. }\end{array}$ \\
\hline Małgorzata, aged 68 & $\begin{array}{l}\text { It helps in choosing company, provides contact with mentors, and } \\
\text { suggests literature that enriches my worldview. }\end{array}$ \\
\hline Elwira, aged 76 & $\begin{array}{l}\text { It sets a good example. It also supports all kinds of activity } \\
\text { without being critical of one's views. }\end{array}$ \\
\hline
\end{tabular}




\begin{tabular}{|l|l|}
\hline Zuzanna, aged 68 & $\begin{array}{l}\text { It acts as a trigger for new ideas. It also supports different kinds of } \\
\text { physical and mental activity as well the development of skills. }\end{array}$ \\
\hline Barbara, aged 69 & $\begin{array}{l}\text { It lets you meet other people. It is a platform for the exchange of } \\
\text { ideas and gives an opportunity to learn. }\end{array}$ \\
\hline Małgorzata, aged 62 & $\begin{array}{l}\text { It supports one's audacity. It gives a sense that where there is will, } \\
\text { there is a way. It enables out-of-the-box thinking. }\end{array}$ \\
\hline Czesław, aged 63 & $\begin{array}{l}\text { It responds to one's need to learn. It makes you learn more than } \\
\text { you expected and provides the opportunity to observe the activity } \\
\text { of other people. }\end{array}$ \\
\hline
\end{tabular}

Source: Own work.

The interviewees confirmed that participation in such activities has increased their entrepreneurship, freed their ingenuity, and liberated them from the fear of criticism. The results obtained in this part of the study confirmed the suggestions of Małyska (2015) that entrepreneurship and creativity on the part of older people are supported by positive emotions. Such emotions are indeed initiated by the environment of the University of the Third Age at the Sopot School of Social Psychology.

\section{References}

Dyer, W.G., Jr. (1994). Toward a Theory of Entrepreneurship Careers. Entrepreneurship Theory and Practice, 19, 7-21.

Erikson, E. (2004). Tożsamość a cykl życia [Identity and the life cycle]. Poznań: Zysk i S-ka Publishers.

Frankfort-Nachmias, C. and Nachmias, D. (2001). Metody badawcze w naukach społecznych [Research methods in the social sciences]. Poznań: Zysk i S-ka Publishers.

Gdańsk Statistical Office. (2016). Uniwersytety trzeciego wieku - wstępne wyniki badania za rok 2014/2015 [Universities of the third age: Preliminary study results for the year 2014/2015]. Gdańsk: Department of Research into Society and Living Conditions GUS Gdańsk Statistical Office.

Gielnik, M., Zacher, H., and Frese, M. (2012). Focus on Opportunities as a Mediator of the Relationship between Business Owners' Age and Venture Growth. Journal of Business Venturing, 27(1), 127-142.

Górniak, J. (Ed.). (2013). Młodość czy doświadczenie? Kapitał ludzki w Polsce [Youth of experience? Hyman capital in Poland]. Report summarizing the 2nd edition of BKL Studies, 2012. Warsaw: PARP Polish Agency for Enterprise Development.

Gruszewska, E. (2014). Transformacja wartości a postawy przedsiębiorcze Polaków. Annales [The transformation in values and the entrepreneurial attitudes of Poles]. Etyka $w \dot{z} y c i u$ gospodarczym [Ethics in economic life], 17(3), 91-101.

Halicka, M. (2004). Satysfakcja życiowa ludzi starych. Studium teoretyczno-empiryczne [Life satisfaction in the elderly: A theoretical and empirical study]. Białystok: Medica Academy. 
Hasińska, Z. and Tracz, E. (2013). Rola uniwersytetów trzeciego wieku w aktywnym starzeniu się [The role of Universities of the Third Age and aging]. Nauki Społeczne [Social Sciences], $1(7), 91-102$.

Janczewski, J. (2005). Kryteria i miary przedsiębiorczości w małej firmie [Entrepreneurship criteria and measurements in a small company]. Przedsiębiorczość - Edukacja [Entrepreneurship-Education], 1, 115-120.

Kautonen, T., Tornikoski, E., and Kibler, E. (2011). Entrepreneurial Intentions in the Third Age: The Impact of Perceived Age Norms. Small Business Economics, 37(2), 219-234, http://dx.doi.org/10.1007/s11187-009-9238-y.

Klimczuk, A. (2013). Kierunki rozwoju uniwersytetów trzeciego wieku w Polsce [Directions of development of Universities of the Third Age]. E-mentor, 4(51), http://www.e-mentor. edu.pl/artykul/index/numer/51/id/1048 (04.03.2016).

Knabit, L., OSB (2016). Młodość to nie tylko wiek. młodość to stan ducha. Motywatory Ojca Leona [Youth is not just an age, it is a state of mind: Father Leon's motivators]. Cracow: Benedictine Press Tyniec.

Kocowski, T. and Tokarz, A. (1991). Prokreatywne i antykreatywne mechanizmy motywacji aktywności twórczej [Proactive and anti-active mechanisms motivating creative activity]. In: A. Tokarz (red.), Stymulatory i inhibitory aktywności twórczej [Creative activity stimulators and inhibitors] (pp. 241-274). Cracow: SAWW.

Konecki, K. (2000). Studia z metodologii badań jakościowych: Teoria ugruntowana [Studies on the methodology of qualitative research: A well-founded theory]. Warsaw: PWN Scientific Publishers.

Kostera, M. (1998/2003). Antropologia organizacji: Metodologia badań terenowych [Organizational anthropology: Methodology of field research]. Warsaw: PWN Scientific Publishers.

Kraśnicka, T. (2002). Koncepcja rozwoju przedsiębiorczości ekonomicznej i pozaekonomicznej [The concept of economic and non-economic entrepreneurship development]. Katowice: Katowice University of Economics Press.

Kraśnicka, T. (2009). Przedsiębiorczość sektora publicznego i jej uwarunkowania [Entrepreneurship in the public sector and its conditions]. In: A. Frąckiewicz-Wronka (Ed.), Zarządzanie publiczne - elementy teorii i praktyki [Public management: Elements of theory and practice]. Katowice: Karol Adamiecki Katowice University of Economics Press.

Kurzowa, Z., Kubisz-Mędrala, Z., Skarżyński, M. and Winiarska, J. (2016). Słowik Synonimów [Thesaurus]. Warsaw: PWN Scientific Publishers.

Levesque, M. and Minniti, M. (2011). Age Matters: How Demographics Influence Aggregate Entrepreneurship. Strategic Entrepreneurship Journal, 5(3), 269-284, http://dx.doi. org/10.1002/sej.117.

Liwiński, J., Giza-Poleszczuk, A., Góra, M. and Sztanderska, U. (2008). Dezaktyacja osób $w$ wieku okołoemerytalnym. Raport $z$ badań [The deactivation of near-retirement-age people: Research report]. Warsaw: Departament Analiz Ekonomicznych i Prognoz Ministerstwo Pracy i Polityki Społecznej [Department of Economic Analyses and Forecasts or the Ministry for Labor and Social Policy].

Małyska, A. (2015). Czy seniorzy sa (moga być) kreatywni? [Are (can) seniors be creative?]/ Portal Crealdi.pl. Retrieved from: http://crealdi.pl/czy-seniorzy-sa-moga-byc-kreatywniare-senior-citizens-creative-or-can-they-be-creative/ (034.01.2015).

Matusiak, K. (2006). Rozwój systemów wsparcia przedsiębiorczości - przesłanki, polityka, instytucje [The development of entrepreneurial support systems: Circumstances, policies, 
institutions]. Radom-Łódź: Institute for Sustainable Technologies - National Research Institute Press.

Miszczak, E. (2006). Stereotypowy obraz człowieka starego [A stereotypical view of an old person]. In: J.T. Kowaleski and P. Szukalski (Eds.), Starość i starzenie się jako doświadczenie jednostek $i$ zbiorowości ludzkich [Old age and aging as an experience of individuals and groups of people] (pp. 305-311). Łódź: Department of Demographics of the University of Łódź.

Partyka, M. (1999). Zdolni, utalentowani, twórczy [Skilled, talented, creative]. Warsaw: Center for Methodical Psychological and educational Assistance of the Minister of National Education.

Piasecki, B. (1998). Przedsiębiorczość i mała firma. Teoria i praktyka [Entrepreneurship and the small company]. Łódź: University of Łódź Press.

Richert-Kaźmierska, A. (2013). Przedsiębiorcy pokolenia baby boomers wobec innowacyjności [Entrepreneurs of the baby boomer generation and innovation]. Zeszyty Naukowe Uniwersytetu Szczecinskiego [Scientific Journals of the University of Szczecin], No. 795, Ekonomiczne Problemy Ustug [Economic issues in services], No. 109, 101-118.

Shapero, A. and Sokol, L. (1982). Social Dimensions of Entrepreneurship. In: C. Kent, D. Sexton, and K. Vespers, The Encyclopedia of Entrepreneurship (pp. 72-91). New York: PrenticeHall, Englewood Cliffs.

Sherman, E. (2015). Six Oldest CEOs in America in 2015. Fortune. Retrieved from: http:// fortune.com/2015/12/13/oldest-ceos-fortune-500/ (13.12.2015).

Silverman, D. (2009). Prowadzenie badań jakościowych [Conducting qualitative research]. Warsaw: PWN Scientific Publishers.

Stephan, U., Hart, M., and Drews C. (2015). Understanding Motivations for Entrepreneurship: A Review of Recent Research Evidence. Birmingham: Enterprise Research Centre and Aston Business School.

Strojny, J. (2007). Kształtowanie postawy przedsiębiorczej - procesy socjalizacji i autokreacji [Shaping entrepreneurial attitudes: Processes of socialization and auto-creation]. In: P. Wachowiak, M. Dąbrowski, and B. Majewski (Eds.), Kształtowanie postaw przedsiębiorczych a edukacja ekonomiczna [Shaping entrepreneurial attitudes and an economic education] (pp. 205-211). Warsaw: FPiAKE Foundation for the Promotion and Accreditation of Economic Education.

Sudoł, S. (2008). Przedsiębiorczość - jej pojmowanie, typy i czynniki ją kształtujące [Entrepreneurship: Its understanding, types, and molding factors]. Problemy Zarządzania [Management Issues], 2(20), 9-26.

Sztumski, J. (1995). Wstęp do metod $i$ technik badań społecznych [Introduction to social research methods and techniques]. Katowice: Śląsk Ltd.

Szukalski, P. (2004). Uprzedzenia i dyskryminacja ze względu na wiek (ageism) - przyczyny, przejawy, konsekwencje [Age-based prejudice and discrimination: Causes, manifestations, and consequences]. Polityka społeczna [Social Policy], 2, 11-15.

Szukalski, P. and Szatur-Jaworska, B. (2014). Aktywne starzenie się. Przeciwdziałanie barierom [Active aging: Working against barriers]. Łódź: University of Łódź Press.

Trypka, E. (2008). Ponad - czasowa pamięć. Jak zatrzymać młodość umysłu i radzić sobie $z$ zaburzeniami pamięci u osób starszych [Timeless memory: How to keep the mind young and cope with memory loss in the elderly]. Wrocław: Biblioteka Nestora [The Nestor Library]. 
Wach, K. (2015). Przedsiębiorczość seniorów jako komponent przedsiębiorczości inkluzywnej: wstępna synteza [Entrepreneurship in senior citizens as a component of inclusive entrepreneurship: Preliminary synthesis]. Horyzonty wychowania [Horizons of Education], 14(32), 99-112.

Wasilczuk, J. (2014). Starzejący się przedsiębiorca w Polsce i na świecie [The aging entrepreneur in Poland and around the world]. Research on Enterprise in Modern Economy: Theory and Practice, 8, 51-59. 


\section{Anna Dolot*}

\section{The Observed and Expected Behavior of Immediate Superiors: The Employees' Perspective ${ }^{1}$}

The article presents the significance and role of immediate superiors and their behaviors in human resource management. A study of various publications made it possible to define tasks that immediate superiors should accomplish while managing their team of employees. Both various publications and supplementary studies were taken into consideration in the discussion concerning the expected behaviors and attitude of immediate superiors. The key element of the paper is the presentation of the author's research results that show the behaviors of immediate superiors, both observed and expected, by employees of Polish companies. The article ends with conclusions that might prove useful in business practice to optimize and improve human resource management processes as well as superior-employee relations.

Keywords: superior, skills, competencies, behavior, manager.

\section{Zaobserwowane i oczekiwane zachowania zwierzchników z punktu widzenia pracowników}

Artykuł ukazuje znaczenie i rolę bezpośrednich zwierzchników oraz ich zachowania jako elementów zarządzania zasobami ludzkimi. Przegląd różnych publikacji umożliwił zdefiniowanie zadań, jakie bezpośredni zwierzchnik powinien realizować w trakcie kierowania zespołem pracowników. Zarówno publikacje, jak i badania pomocnicze zostały uwzględnione przy dyskusjach na temat oczekiwanego zachowania, a także podejścia bezpośrednich zwierzchników. Kluczowym elementem niniejszego artykułu jest przedstawienie rezultatów badań autora, które pokazują zachowania bezpośrednich zwierzchników - te obserwowane i te oczekiwane przez pracowników polskich firm. Artykuł zamykają wnioski, które mogą zostać wykorzystane w praktyce biznesowej by zoptymalizować oraz ulepszyć procesy związane z zarządzaniem zasobami ludzkimi oraz stosunki zwierzchnik - pracownik.

Słowa kluczowe: zwierzchnik, umiejętności, kompetencje, zachowanie, kierownik.

JEL: M500

* Anna Dolot, Ph.D. - Cracow University of Economics; ul. Rakowicka 27, 31-510 Cracow; e-mail: anna.dolot@uek.krakow.pl.

1 This article was financed thanks to subsidies for maintaining research capacity granted to the Cracow University of Economics. 


\section{Introduction}

Modern human resources in a company are regarded as one of the key indicators of competitiveness (Jamka, 2002). This is particularly observable as well as crucial in companies operating in the service sector, where the role of an employee-their competencies, demonstrated behaviors, commitment, and relations built with company business partners in the broadest sense-may contribute to organizational performance (Grobelna, 2014; Haynes and Fryer, 2000; Little and Dean, 2006). However, it seems that regardless of the character of a given company, it is its employees that create its image both inside and outside the organization. It is the inner image, atmosphere, and organizational culture that have an impact on employees, their motivation, effectiveness, attitude towards tasks, and performance of defined objectives (Kim, Lee, and Yu, 2004; Laforet, 2016). It is precisely at this point that the figure of the manager, leader, director, superior-the person who manages a defined group of employees-comes in. The role of this immediate superior is being stressed more and more often. Both theory and practice notice that person's influence on employees (Nelson, 1999; Tietjen and Myers; Wiley, 1997). Therefore, worth studying are guidelines addressed to immediate superiors by specialists as well as research results that show how a Polish immediate superior is perceived and just what their employees expect them to be like.

The aim of this article is to answer the following questions: What kind of behavior is expected on the part of the superior by that superior's employees and what kind of behavior by the superior is actually observed by employees. This article consists of a review of scientific literature (Polish and foreign) in the field of the discussed issues, an analysis of supplementary research results, and empirical research results.

\section{Immediate Superior: Role and Tasks in the Context of People Management}

There are many terms describing employees who manage people. They include director, manager, leader, and more colloquially, the boss. There are differences relating to approach to these terms in both literature and commercial practice. In literature, director, manager, and leader are subject to terminological discussion (Ackerman, 1985; Leicester, 1990). On the other hand, the terms director and manager are used interchangeably very often 
(e.g., Bolesta-Kukuła, 1993; Mroziewski, 2005; Penc, 2008). In the business practice of many organizations, a leader is an employee managing a given group of people who is subordinate to a manager. On the other hand, the term director is more frequently used in structures of public administration than in global corporations. However, for the purposes of this article, these differences shall not be discussed as all the people described by the above terms share one common feature, they are immediate superiors for the employees in the team they manage. The behaviors of this immediate superior as seen from the point of view of the employee are a key research area for this article. ${ }^{2}$

Analyzing the issue of a range of responsibilities, specialists point out that a manager performs the following tasks or plays the following roles (Drucker, 1994):

- Defines aims,

- Organizes work and structures,

- Motivates and informs, and

- Contributes to the development of people.

Another author writes that managers perform four basic managerial activities (Griffin, 2004):

- Planning and decision making,

- Organizing,

— Leading, i.e. managing people, motivating, and

- Controlling.

Quoted sources show the superior's role from the perspective of widelyunderstood management. This context of people management is emphasized by other specialists and shows that fulfilling managerial functions has a significant impact on attitudes, working conditions, and employee remuneration, and hence, on the degree of satisfaction of their needs, and their satisfaction and loyalty to the organization (Jasińska, 2010). It is even emphasized that the greatest responsibility for current employee management rests on immediate superiors (Rostkowski, 2014). They are required to manage their resources efficiently on an everyday basis, and to be actively involved in all human resource management processes, including employment planning, selecting and preparing employees for their tasks, evaluating, planning and implementing personal development processes, and motivating.

2 The words director, manager, and leader as well as adjectives derived from them shall be used, followed by quoted sources (concerning their role as an immediate superior). 


\section{Skills, Competencies, and Behaviors: Terminological Considerations}

There are many terms describing requirements and expectations towards superiors in both theory and business practice. Scientific research exists and tests are being conducted concerning the skills or competencies that a superior must have to be efficient in the role. The term behaviors is used in the presented research.

Looking at the term skills, it is defined as "practical knowledge of something, fluency in something, ability to do something" (Dubisz, 2006, p. 238). However, from a practical point of view, having skills does not equal using them, acting and, as a consequence, manifesting particular behaviors. For many specialists, this element of "human agency" seems to be a distinctive feature of competencies that are commonly used and defined in many ways. At the same time, skills in the definitions of many authors constitute elements of competencies, a necessary but not sufficient condition (Boyatzis, 1982; Levy-Leboyer, 1997; Mikuła, 2001; Pawlak, 2003; Yuvaraj, 2011). It should be emphasized that there are several specialists who include this aspect of behavior in their definitions of competencies. Lévy-Leboyer stresses that competencies are expressed in behaviors that contribute to professional success at a given position (1997). She states that they are sets of knowledge elements and skills, typical behaviors, standard procedures, ways of reasoning, which can be used without learning anything new. Other specialists define competencies as "behaviors of individuals undertaking effective actions within their workplace in the organizational context" (Whiddett and Hollyforde, 2003, p. 11). From the terminological point of view, skills, competencies, and behaviors are definitely not the same thing, but rather overlap and interpenetrate each other. Specialists also emphasize that a discussion on terms such as skills and competencies can lead to as many definitions and typologies of skills and competencies as there are researchers working on them (Markowitsch and Plaimauer, 2009). There is one more term occurring in literature-managerial behavior-which is sometimes used to refer to the behavior itself, often described as what managers do or managerial jobs. Managerial behavior, therefore, is what managers do in practice and which, to a large extent, lends itself to observation or selfassessment (Frempong, Ahenkora, and Asamoah, 2013).

In commercial practice, names of competencies often include the term skill (e.g., "group relation building skills"). Moreover, during the development of competency systems (used for recruitment and selection, or employee assessment, for example), competencies are defined by way of 
what is known as model behaviors (in literature these are also defined as indicators-desired behaviors) (Cooper, 2000; Emiliani, 2003). One competency can be defined by several or sometimes even a dozen model behaviors. This is so because even the example of competency given above-i.e. "group relation building skills"-can be interpreted differently in different organizations. In order to explain to an employee what is expected from his or her work, that employee is presented with expected (model) behaviors. What is more, different people can interpret the name for a given competency differently. Defining competencies by way of model behaviors aims at eliminating communication misunderstandings. It shows employees the direction of expected actions and gives general answers to their questions: "How shall I behave to make my behavior as expected? What shall I do?" Thus, also in practice, the terms skills, competencies, and behavior coexist and exist side by side. Introducing the term behaviors into this research is deliberate and practical in character. It shows specific observed and expected behaviors by superiors from the perspective of their subordinates.

In summing up scientific and practical areas of commonly used terminology, worth emphasizing is that it is not only about superiors possessing particular skills or competencies, but also about their impact on manifested behaviors.

\section{Expectations towards Superiors: A Review of Supplementary Research}

Literature describes a great deal of research devoted to the issue of immediate superiors and the influence of their skills, competencies, and behaviors on employee motivation and development (Milne, 2007; Nelson, 1999), their employees' work results and effectiveness (Dumdum, Lowe, and Avolio, 2002), and themselves (Tonidandel, Braddy, and Fleenor, 2012).

There are also numerous publications that point to particular skills and competencies that are expected from people who supervise other employees. Table No. 1 presents the results of selected research. It gives examples of skills, competencies, and sample model behaviors (defining those competencies). 
Table No. 1 Skills, Competencies, and other Expectations towards Superiors: A Review of Supplemental Research

\begin{tabular}{|c|c|}
\hline Author & Expectations towards Superiors \\
\hline $\begin{array}{l}\text { H. Mintzberg - Described } \\
\text { managerial skills, making } \\
\text { them more precise using the } \\
\text { concept of expected behav- } \\
\text { iors (in parentheses). }\end{array}$ & $\begin{array}{l}\text { Peer skills (deal with the manager's ability to enter into and } \\
\text { effectively maintain peer relationships). } \\
\text { Leadership skills (focus on the manager's ability to deal } \\
\text { with subordinates, to motivate and train them, provide help, } \\
\text { deal with problems of authority and dependence, etc.). } \\
\text { Conflict-resolution skills (include interpersonal skill for } \\
\text { mediating between individuals in conflict and decisional } \\
\text { skill for handling disturbances). } \\
\text { Information-processing (managers should know how to } \\
\text { build informal information networks, find sources of infor- } \\
\text { mation and extract what they need, validate information, } \\
\text { assimilate it, and build effective mental models). } \\
\text { Skills in decision making under conditions of ambiguity } \\
\text { (these are important because the unstructured situation is } \\
\text { the one that is the most characteristic of top management } \\
\text { decision making. The manager must first decide when a deci- } \\
\text { sion must be made, diagnose the situation and plan and } \\
\text { approach to it, search for solutions and evaluate their con- } \\
\text { sequences, and, finally, select an alternative). } \\
\text { Resource-allocation skills (used when managers are required } \\
\text { to choose among competing resource demands. They must } \\
\text { decide how to allocate their own time, determine what work } \\
\text { their subordinates must do and in what formal structure } \\
\text { they must work, and pass judgments, sometimes very } \\
\text { quickly, on projects that require organizational resources). } \\
\text { Entrepreneurial skills (involve the search for problems and } \\
\text { opportunities and the skills needed to implement change } \\
\text { in organizations). } \\
\text { Introspection skills (relate to the manager's understanding } \\
\text { of his or her job, where a manager's introspection should } \\
\text { be sensitive to his or her own impact on the organization, } \\
\text { and he or she should be able to learn by introspection). }\end{array}$ \\
\hline $\begin{array}{l}\text { S. E. Scullen, M. K. Mount } \\
\text { and T. A. Judge - Developed } \\
\text { a four-factor typology of } \\
\text { managerial skills. }\end{array}$ & $\begin{array}{l}\text { Technical skill. } \\
\text { Administrative skill. } \\
\text { Human skill. } \\
\text { Citizenship behavior. }\end{array}$ \\
\hline $\begin{array}{l}\text { S. R. Covey - Defined the } \\
\text { features of leaders (in the } \\
\text { form of behaviors), where in } \\
\text { relation to each he pointed to } \\
\text { several behaviors / activities }\end{array}$ & $\begin{array}{l}\text { Leaders constantly acquire new knowledge (e.g., they con- } \\
\text { stantly develop by collecting new experiences as well as by } \\
\text { developing new skills and interests). } \\
\text { Leaders are ready to serve others (e.g., they treat their life } \\
\text { as a mission not a career). }\end{array}$ \\
\hline
\end{tabular}




\begin{tabular}{|c|c|}
\hline $\begin{array}{l}\text { (examples are given in } \\
\text { parentheses). }\end{array}$ & $\begin{array}{l}\text { Leaders send positive energy (e.g., their attitude is opti- } \\
\text { mistic). } \\
\text { Leaders believe in other people (e.g., they believe that there } \\
\text { is potential in people). } \\
\text { Leaders maintain harmony in life (e.g., they have many } \\
\text { interests and are intellectually active). } \\
\text { Leaders consider life an adventure (e.g., they are interested } \\
\text { in people, ask them questions, listen to them, and learn } \\
\text { from them). } \\
\text { Leaders are synergic (e.g., they act as a catalyst for change). } \\
\text { Leaders regularly develop four areas of their personality- } \\
\text { physical, mental, emotional, and spiritual. }\end{array}$ \\
\hline $\begin{array}{l}\text { M. Sasin - Defined manage- } \\
\text { rial competencies, pointing } \\
\text { to more detailed tasks and } \\
\text { actions to be performed } \\
\text { within a given competency. }\end{array}$ & $\begin{array}{l}\text { Focus on a goal to be reached. } \\
\text { Focus on transparent relations in a team. } \\
\text { Effective communication with employees. } \\
\text { Improving work processes. } \\
\text { Focus on the achievement of long-term goals. } \\
\text { Consistent behavior. } \\
\text { Building employee commitment. }\end{array}$ \\
\hline $\begin{array}{l}\text { J. X. Qiao and W. Wang - } \\
\text { Defined managerial compe- } \\
\text { tencies for middle managers. }\end{array}$ & $\begin{array}{l}\text { Team building. } \\
\text { Communication. } \\
\text { Coordination. } \\
\text { Execution. } \\
\text { Continual learning. }\end{array}$ \\
\hline $\begin{array}{l}\text { E. O. Frempong et al. - } \\
\text { Described managerial com- } \\
\text { petence creating a positive } \\
\text { workplace experience for } \\
\text { employees. }\end{array}$ & $\begin{array}{l}\text { Giving others credit for their ideas and suggestions. } \\
\text { Setting priorities based on business needs. } \\
\text { Fair and equitable treatment. } \\
\text { Respecting the rights of others. } \\
\text { Considering employee views. } \\
\text { Asking for comments and suggestions from staff members. } \\
\text { Promoting good working relationships among staff mem- } \\
\text { bers. } \\
\text { Involving employees in decision-making. } \\
\text { Improving staff commitment to organizational performance. } \\
\text { Settling employee disputes quickly. } \\
\text { Bringing others "on board" regarding new plans. }\end{array}$ \\
\hline $\begin{array}{l}\text { B. A. Hogg - Created the } \\
\text { "Typically "Needed and } \\
\text { Most Vital Competences," } \\
\text { research results in the area } \\
\text { of managerial competences. }\end{array}$ & $\begin{array}{l}\text { Problem solving (analysis). } \\
\text { Oral communication. } \\
\text { Decision-making. } \\
\text { Sense of purpose / goal orientation. } \\
\text { Planning and organizing. } \\
\text { Integrity. } \\
\text { Written communication. } \\
\text { Teamwork. }\end{array}$ \\
\hline
\end{tabular}




\begin{tabular}{|l|l|}
\hline & Technical / professional knowledge. \\
Interpersonal communication. \\
Organizational awareness. \\
Self-awareness and self-control (maturity). \\
Creativity. \\
Learning. \\
Leadership. \\
Self-development. \\
Development of subordinates. \\
Balanced approach. \\
Stress management. \\
Innovation and strategic vision. \\
Financial awareness. \\
Adaptation to foreign cultures. \\
\hline
\end{tabular}

Source: Own study on the basis of Covey, 2011; Frempong et al. (2013), Hogg (1993), Mintzberg (1973), cited in Yau and Sculli (1990), Sasin (2015), Scullen, Mount, and Judge (2003), and Qiao and Wang, 2009.

This analysis of supplemental research results shows a broad range of expectations with respect to superiors. They encompass both elements of broadly-understood communication, building relations, development and improvement, planning, and consistency in action as well as expectations perceived in more technical categories. It should be emphasized that none of above expectations towards superiors were indicated by employees (which is the aim of this paper).

However, evidence shows that to be effective, different hierarchical positions require different skills (Yau and Sculli, 1990), managerial behaviors (Kraut, Pedigo, McKenna, and Dunnette, 2005), and competencies (Qiao and Wang, 2009). Thus, there are even a greater variety of expectations towards superiors.

Worth emphasizing is the fact that the issue of the skills and competencies of superiors that have a positive impact on the team as well as the effects of its work is widely discussed and also constitutes a frequent topic of popular-scientific publications. "How to manage efficiently?" "How to be a good, professional superior?" These are questions that constitute an area of interest not only for superiors, but also for candidates for such positions, trainers, coaches, consultants, and counselors.

A last element worth noting is the fact that literature includes research pointing to a disproportion in the perception of areas concerning leadership between superiors and their employees (Werbel and Henriques, 2009). However, this phenomenon seems to be natural and psychologically justified. Different expectations towards superiors can be 
expressed by their subordinates, owners, and organization managers (that is their superiors).

\section{Observed and Expected Behaviors: Empirical Research}

\subsection{Research Methodology and Research Sample}

Empirical research concerning observed and expected behaviors on the part of immediate superiors was conducted in cooperation with ATERIMA, a Polish employment agency, which creates flexible solutions in the area of outsourcing process management and conducts specialist recruitment. A total of 315 respondents took part in the research. It was conducted using questionnaires that consisted of list of thirteen immediate superior behaviors. Those behaviors were chosen on the basis of typologies quoted in Part 4. Although none of the quoted typologies was directly used in the questionnaire, the thirteen behaviors were chosen and adopted from them (mainly Frempong et al.) as were additional behaviors observed in business practice (both expected and existing). Respondents were asked to choose six expected behaviors on the part of their immediate superiors (behaviors they appreciate). They were also asked to choose a minimum of one and a maximum of six observed behaviors by immediate superiors in day-to-day business situations.

The research was conducted among candidates that took part in the ATERIMA recruitment process as well as among ATERIMA's business partners. Additionally, the questionnaire was available on ATERIMA's web page and was promoted on HR portals (e.g., www.hrpolska.pl and www.hrnewes. $\mathrm{pl}$ ). The sample varied in many aspects. The majority of respondents (as many as $73 \%$ ) were women. A dominant group of respondents consisted of people aged 26-30 (43\%), followed by the 31-35 and up to the age of 25 (19\% each), 36-40 (10\%), 41-45 (5\%), and over 46 (4\%). Most frequently, respondents' professional experience amounted to two to five years (38\%), six to ten years $(25 \%)$, fewer than two years $(16 \%)$, eleven to fifteen years (11\%) and over fifteen years (10\%). A total of $26 \%$ of respondents occupied managerial positions (supervised a subordinate team). The majority of the respondents worked in organizations employing more than 250 employees (34\%). Somewhat fewer (33\%) were employed in organizations employing from 50 to 249 employees. Small enterprises (10-49 employees) employed $19 \%$ of respondents. Employees of micro-enterprises (up to nine employees) made up the smallest group (13\%). The research was conducted between January and September of 2015. 


\subsection{Results of Conducted Research}

The conducted research shows a large disproportion between observed and expected behaviors on the part of immediate superiors in the eyes of their employees. (Results are presented in Figure No. 1.)

Figure No. 1 Expected and Observed Behaviors of Immediate Superiors from the Perspective of Their Subordonates (Own research results)

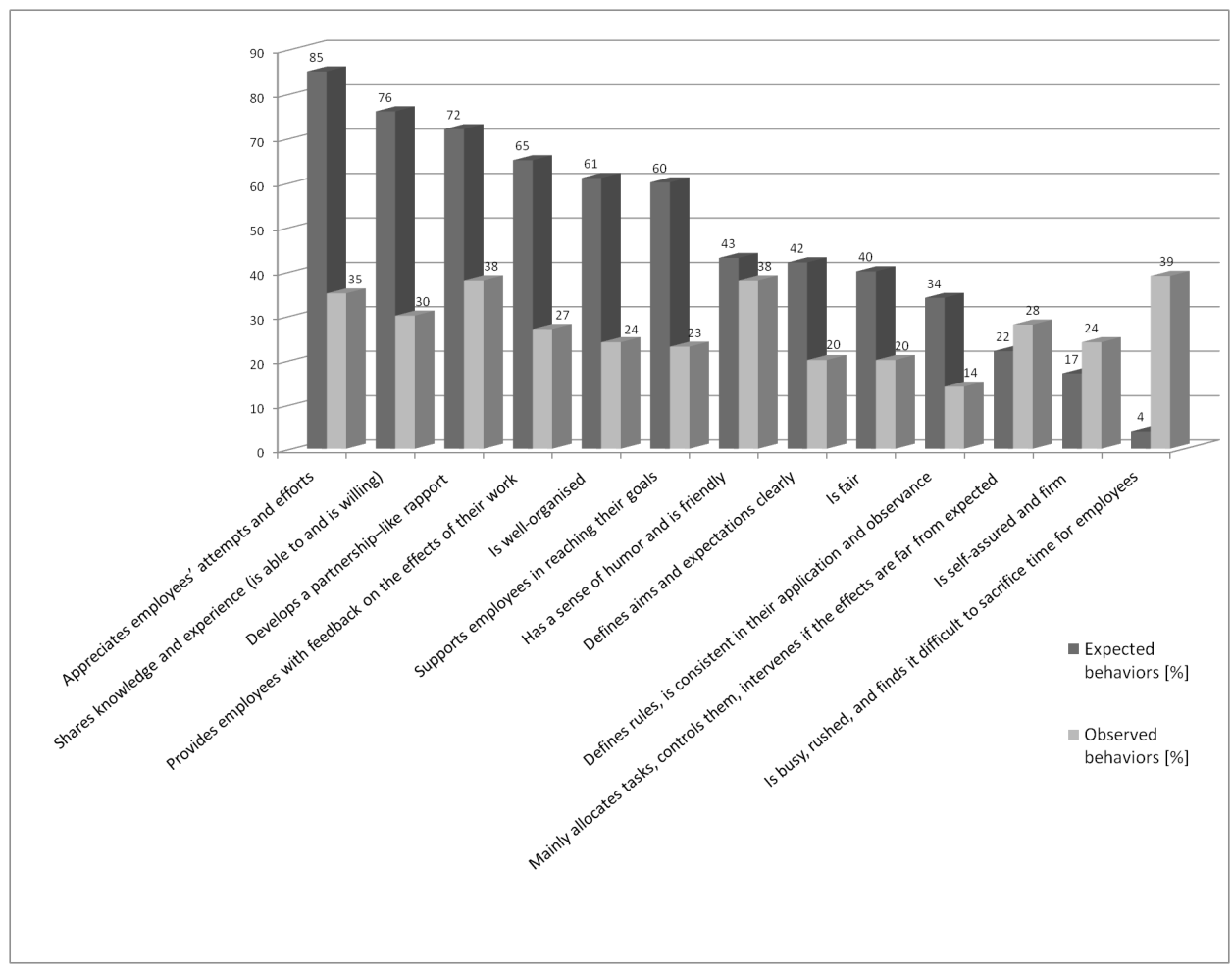

Source: Own study.

Starting with an analysis of behaviors expected on the part of respondents, what is visible is that appreciation of attempts and efforts undertaken by employees is considered a key factor (85\%). The second most important behavior on the part of the superior from the point of view the respondents is sharing knowledge and experience (76\%). Third place (72\%) is occupied by expectations towards building a partnership-like rapport with employees (knowing subordinates, treating them with respect, and showing interest in their opinions). Employees also expect feedback on the effects of their work $(65 \%)$. 
As was expected, employee expectations do not envisage a busy superior, a person who is rushed, but someone who is self-assured and resolute, allocating tasks, monitoring them, and intervening if work results deviate significantly from expectations.

On the other hand, research results show that immediate superiors are perceived by their employees as busy people, living in a hurry, and not having any time for their employees (39\%), but creating a partnershiplike rapport and having a sense of humor (38\% each). It is worth noting that the biggest disproportion between expected and observed behaviors occurs in the following areas: appreciation of employee attempts and efforts (a 50 point difference) and sharing knowledge and experience with employees (a 46 point difference). These two types of behavior are the ones that are most expected, but are observed to the slightest degree among the immediate superiors of the respondents.

Comparing the above research to a different study in the area of employee expectations (Lester, Claire, and Kickul, 2001), areas such as development, respect, open and honest communication, and fairness are important to employees and appreciated by them worldwide.

\section{Conclusions and Practical Implications}

Appreciating employee attempts and effort can take different forms, both material and non-material. In case of material forms, the organization might use its lack of sufficient means as an excuse. It should be admitted, though, that thanking an employee for performed tasks or appreciating their engagement in the organization's development does not cost anything with the exception of some time. It shows that their superior notices an employee as well as his or her work and commitment.

Sharing knowledge and experience by the superior is an example of a competency that is more and more frequently desired and highly valued in managers in the eyes of company owners and HR departments conducting recruitment for managerial positions. It is thanks to such a sharing process that organizations have the opportunity to develop, secure new markets, increase employment, avoid mistakes, and learn from any mistakes made. Sharing knowledge might be one of the most important work motivation factors as it builds a relationship and loyalty between a superior and employee, creates the superior's image as someone who is courageous (not afraid of sharing knowledge) or even as someone who is charismatic. A superior can be a mentor. A superior can initiate and support the use of 
other training methods (e.g., job rotation, project work, workshops, quality circle meetings, and action learning). Unfortunately, Poland is still a country where stereotypes like the following exist: "If I praise my employee, they will expect a pay raise." "If I share knowledge, somebody will replace me soon." Managers applying such reasoning, and therefore their teams shall never achieve their true potential as well. It is also worth bearing in mind that the development process is usually bi-directional. Although it is the learner who develops first and foremost, the teacher also has an opportunity to expand knowledge, experience, and to broaden horizons. This happens through dialogue, where one can become familiar with a different way of reasoning, acting, and with different motives for actions.

A superior's individual approach towards an employee is also worth emphasizing. This is because what will work well for one manager in one situation may be disastrous in another (Miller, 1991).

Talking about employees as being the most crucial organizational resource is not sufficient. Words must be followed by actions and behaviors on the part of people who manage employees-managers, leaders, directors, and bosses. Appreciating one's employees, sharing knowledge with them, and treating them with respect are behaviors expected of employers.

Disproportion between behaviors that are most expected, but not sufficiently observed can lead to decreased employee motivation, lower job satisfaction, and even (especially under other unfavorable conditions) the intension to look for a different employer. There is a common phrase in business practice: "You join a company, you leave your supervisor."

On the basis of the above research results it would be interesting to present the results to immediate superiors and investigate the real reasons for a lack of appreciation for employees or for sharing knowledge-a direction for further research. Maybe immediate superiors do not even have an awareness of this situation? The assumption that they are afraid of their employees' reaction (e.g., higher salary, replacing the manager) is only a guess. Additionally, it would be interesting to investigate the opposite side of this business cooperation-employee behaviors that are both observed and expected on the part of their immediate superiors. An aim of further research could be into which employee behaviors are the real motivators as well as a kind of catalyst for managers, their team effectiveness, and goal accomplishment. 


\section{References}

Ackerman, L. (1985). Leadership vs. Managership. Leadership \& Organization Development Journal, 6(2), 17-19, http://dx.doi.org/10.1108/eb053573.

Boyatzis, R. (1982). The Competent Manager. Toronto: John Wiley \& Sons.

Cooper, K.C. (2000). Effective Competency/ Modelling and Reporting. New York: AMA Publications.

Covey, S.R. (2011). Zasady skutecznego przywództwa [Principles of effective leadership]. Poznań: Rebis Publishing House.

Drucker, P. (1994). Praktyka zarzadzania [Management practice]. Cracow: Cracow University of Economics.

Dubisz, S. (2006). Słownik Języka Polskiego [Dictionary of the Polish language]. Warsaw: PWN Scientific Publishers.

Dumdum, U.R., Lowe, K.B., and Avolio, B.J. (2002). A Meta-Analysis of Transformational and Transactional Leadership Correlates of Effectiveness and Satisfaction: An Update and Extension. In: B.J. Avolio and F.J. Yammarino (Eds.), Transformational and Charismatic Leadership: The Road Ahead (pp. 35-66). Oxford, UK: Elsevier Science, http:// dx.doi.org/10.13140/RG.2.1.3549.1681.

Emiliani, M.L. (2003). Linking Leaders' Beliefs to Their Behaviors and Competencies. Management Decision, 41(9), 893-910, http://dx.doi.org/10.1108/00251740310497430.

Frempong, E.O., Ahenkora, K., and Asamoah, A. (2013). Perceptions on Managerial Behaviour and Positive Workplace Experience. International Journal of Business Management \& Economic Research, 4(1), 688-691.

Griffin, R.W. (2004). Podstawy zarządzania organizacjami [Basics of organizational management]. Warsaw: PWN Scientific Publishers.

Grobelna, A. (2014). Zarządzanie zaangażowaniem pracowników w kontekście wzrostu konkurencyjności przedsiębiorstw hotelowych na współczesnym rynku [Managing employee engagement in the context of growing hotel competitiveness on today's market]. Logistyka [Logistics], 3, 2202-2211.

Haynes, P. and Fryer, G. (2000). Human Resources, Service Quality and Performance: A Case Study. International Journal of Contemporary Hospitality Management, 12(4), 240-248, http://dx.doi.org/10.1108/09596110010330813.

Hogg, B.A. (1993). European Managerial Competence. European Business Review, 93(2), 21-26, http://dx.doi.org/10.1108/EUM0000000001914.

Jamka, B. (2002). Adaptacja społeczno-zawodowa pracowników jako instrument strategii personalnej firmy [The social and professional adaptation of workers as an instrument of company personnel strategy]. In: K. Makowski (Ed.), Zarządzanie pracownikami. Instrumenty polityki personalnej [Employee management: Personnel policy instruments]. Warsaw: Poltext.

Jasińska, J. (2010). Stosunki i warunki pracy [Work relations and conditions]. In: T. Listwan (Ed.), Zarzadzanie kadrami [Staff management] (pp. 235-259). Warsaw: C.H. Beck Publishers.

Kim, S., Lee, J., and Yu, K. (2004). Corporate Culture and Organizational Performance. Journal of Managerial Psychology, 19(4), 340-359, http://dx.doi.org/10.1108/02683940410537927.

Kraut, A.I., Pedigo, P.R., McKenna, D.D., and Dunnette, M.D. (2005). The Role of the Manager: What's Really Important in Different Management Jobs. Academy of Management Executive, 19(4), 122-129, http://10.5465/AME.2005.19417914. 
Laforet, S. (2016). Effects of Organisational Culture on Organisational Innovation Performance In Family Firms. Journal of Small Business and Enterprise Development, 23(2), 379-407, http://dx.doi.org/10.1108/JSBED-02-2015-0020.

Leicester, C. (1990). The Strategic Manager as Leader. International Journal of Manpower, 11(4), 3-10, http://dx.doi.org/10.1108/01437729010000998.

Lester, S.W., Claire, E., and Kickul, J. (2001). Psychological Contracts in the 21st Century: What Employees Value Most and How Well Organizations Are Responding to These Expectations. Human Resource Planning, 24(1), 10-21.

Lévy-Leboyer, C. (1997). Kierowanie kompetencjami. Bilanse doświadczeń zawodowych [Managing competencies: The balance of professional experience]. Warsaw: Poltext.

Little, M.M. and Dean, A.M. (2006). Links between Service Climate, Employee Commitment and Employees' Service Quality Capability. Managing Service Quality: An International Journal, 16(5), 460-476, http://dx.doi.org/10.1108/09604520610686133.

Markowitsch, J. and Plaimauer, C. (2009). Descriptors for Competence: Towards an International Standard Classification for Skills and Competences. Journal of European Industrial Training, 33(8/9), 817-837, http://dx.doi.org/10.1108/03090590910993652.

Mikuła, B. (2001). Elementy nowoczesnego zarzadzania. W kierunku organizacji inteligentnych [Elements of modern management: Towards intelligent organizations]. Cracow: Antykwa Publishing House.

Miller, L. (1991). Managerial Competences. Industrial and Commercial Training, 23(6), 11-15, http://dx.doi.org/10.1108/EUM0000000001578.

Milne, P. (2007). Motivation, Incentives and Organisational Culture. Journal of Knowledge Management, 11(6), 28-38, http://dx.doi.org/10.1108/13673270710832145.

Mroziewski, M. (2005). Style kierowania i zarządzania. Wybrane koncepcje [Styles for directing and managing: Selected concepts]. Warsaw: Difin.

Nelson, B. (1999). The Ironies of Motivation. Strategy \& Leadership, 27(1), 26-31, http:// dx.doi.org/10.1108/eb054627.

Pawlak, Z. (2003). Personalna funkcja firmy - procesy i procedury kadrowe [The company personnel function: Staff processes and procedures]. Warszawa: Poltext.

Qiao, J.X. and Wang, W. (2009). Managerial Competencies for Middle Managers: Some Empirical Findings from China. Journal of European Industrial Training, 33(1), 69-81, http://dx.doi.org/10.1108/03090590910924388.

Rostkowski, T. (2014). Podmioty zarządzania kapitałem ludzkim [Entities in the management of human capital]. In: M. Juchnowicz (Ed.), Zarządzanie kapitałem ludzkim. Procesynarzędzia-aplikacje [Managing human capital: Processes - tools - applications] (pp. 169-183). Warsaw: PWN Scientific Publishers.

Sasin, M. (2015). Budowanie zaangażowania [Building engagements]. Gliwice: Helion Publishers.

Scullen, S.E., Mount, M.K. and Judge, T.A. (2003). Evidence of the Construct Validity of Developmental Ratings of Managerial Performance. Journal of Applied Psychology, 88(1), 50-66, http://dx.doi.org.10.1037/0021-9010.88.1.50.

Tietjen, M. A. and Myers, R. M., (1998). Motivation and Job Satisfaction. Management Decision, 36(4), 226-231, http://dx.doi.org/10.1108/00251749810211027.

Tonidandel, S., Braddy, P.W., and Fleenor, J.W. (2012). Relative Importance of Managerial Skills for Predicting Effectiveness. Journal of Managerial Psychology, 27(6), 636-655, http:// dx.doi.org/10.1108/02683941211252464. 
Werbel, J.D. and Henriques, P.L. (2009). Different Views of Trust and Relational Leadership: Supervisor and Subordinate Perspectives. Journal of Managerial Psychology, 24(8), 780-796, http://dx.doi.org/10.1108/02683940910996798.

Whiddett, S. and Hollyforde, S. (2003). A Practical Guide to Competencies: How to Enhance Individual and Organisational Performance. London: CIPD House.

Wiley, C. (1997). What Motivates Employees According to over 40 Years of Motivation Surveys. International Journal of Manpower, 18(3), 263-280, http://dx.doi.org/10.1108/014377297 10169373.

Yau, W.S.L. and Sculli, D. (1990). Managerial Traits and Skills. Journal of Management Development, 9(6), 32-40, http://dx.doi.org/10.1108/02621719010139486.

Yuvaraj, R. (2011). Competency Mapping: A Drive for Indian Industries. International Journal of Scientific \& Engineering Research, 2(8), 1-7. 


\section{Different Faces of Motivation in a Research Institute: A Case Study}

The work of scientists plays a crucial role in today's innovation-driven economy. New products, theories, and inventions create the competitive advantage of nations and companies. That is why it so important to properly manage and motivate scientists. Surprisingly, there are very few studies addressing this issue. The presented research provides the results of a survey conducted among eighteen employees of the Center for Theoretical Physics of the Polish Academy of Sciences. The sample encompasses seven doctoral advisors (professors), six Ph.D. students (research assistants), and five doctors who recently defended their Ph.D. theses. The study uses word counting as well as thorough answer analysis. Surprisingly, what was discovered was that positive work atmosphere is the most important motivator in the sample. Other factors important in motivation are curiosity and intrinsic motivation, which is consistent with current literature on the subject. The other important conclusion of this research is that it is extremely important for the working style of the doctoral advisor ("active" or "passive") to match the Ph.D. student needs and expectations. The presented study has certain limitations. First of all, since qualitative methods are used it is not possible to extrapolate conclusions to other scientific institutions. Moreover, it was not possible to include Ph.D. students who failed in their studies in the sample. Nevertheless, the conclusions indicate the direction for further research.

Keywords: motivation, motivation in science, motivation of doctoral students, motivation of researchers, relation between doctoral advisor and doctoral candidate.

\section{Różne twarze motywacji w instytucie naukowym - studium przypadku}

W gospodarce opartej na innowacjach kluczową rolę odgrywają obecnie naukowcy. Nowe produkty, teorie czy wynalazki są podstawą przewagi konkurencyjnej krajów lub przedsiębiorstw. Dlatego też niezwykle istotne jest prawidłowe zarządzanie pracą i motywowanie ludzi nauki. Jednak tylko nieliczne badania poruszają tę problematykę.

* Marta Kabut - Faculty of Management, University of Warsaw, e-mail: marta.kabut@ gmail.com, orcid ID: orcid.org/0000-0002-2870-0258.

** Mateusz Kabut, Ph.D. Candidate - Chair of Administration and Management Issues, Faculty of Management, University of Warsaw; Szturmowa Street 1/3, 02-678 Warsaw, Poland; e-mail: mkabut@wz.uw.edu.pl, orcid ID: orcid.org/0000-0003-0569-6142. 
W niniejszym badaniu przeprowadzono ankietę wśród 18 pracowników Centrum Fizyki Teoretycznej Polskiej Akademii Nauk. W próbie znalazło się siedmiu promotorów (profesorów), sześciu doktorantów (asystentów badawczych) oraz pięciu doktorów, którzy niedawno obronili swoje doktoraty. W badaniu zastosowaliśmy metodę liczenia słów oraz szczegółową analizę odpowiedzi. Okazało się, że badanych w największym stopniu motywuje pozytywna atmosfera pracy. Wśród innych motywatorów duże znaczenie miała ciekawość badanych oraz motywacja wewnętrzna, co jest zgodne z wnioskami z istniejącej literatury przedmiotu. Kolejnym interesującym wnioskiem z badań jest, że bardzo duże znaczenia dla motywacji i pracy doktorantów ma dopasowanie stylu pracy promotora (aktywny lub bierny) do potrzeb i oczekiwań doktoranta. Zaprezentowane badanie posiada jednak pewne ograniczenia. Ponieważ jest to badanie jakościowe, nie jest możliwe ekstrapolowanie otrzymanych wyników na ogół instytucji nauki. Ponadto w próbie nie udało się uwzględnić doktorantów, którzy nie ukończyli studiów. Niemniej uzyskane wyniki stanowią ważną podstawę dla dalszych badań.

Słowa kluczowe: motywacja, motywacja w nauce, motywacja doktorantów, motywowanie pracowników naukowych, relacje pomiędzy promotorem i doktorantem.

JEL: M12, M52, J24

\section{Research Problem and Aims}

People sometimes wonder how to motivate themselves to do something they have to do, but they simply do not want to do it at that time. If they are working with others, this becomes more than just a problem of how to motivate themselves to do things and becomes a question of how to motivate others to undertake certain actions. There are many books on this topic and even more articles. Many of them offer various tricks for overcoming lack of motivation, but we are still seeking ways to motivate people to do what we want them to do. These ways have to be different for different places and different people-different for companies with a goal of making profits as high as possible (though this is not always the case, for the purposes of this study it may be assumed that most companies take this to be their most important goal), different in the case of regular people who, for example, want to lose weight, and different for scientists whose main work is thinking and inventing new ways of explaining how the world works and how such rules can be used for the improvement of lives. As development and research become more and more important for today's companies, where even research institutes have to compete subject to more business-like circumstances, it is crucial to know how to work with young scientists and what brings the best out of them, even if they do not believe in themselves and become demotivated because of difficulties occurring on their road to 
success in science. What is necessary is to find crucial aspects of what is important to those scientists as well as finding future study directions and leads for both sides of the relation, if possible.

There is extensive literature and studies on this topic, but Poland is a specific country that has to deal with very specific circumstances. In the five-factor model, Polish people describe themselves as high in neuroticism, low in agreeableness, and average in extraversion, openness, and conscientiousness (Hrebickova and Graf, 2014). It is especially this combination of neuroticism and agreeableness that means that Polish people can be difficult to manage and difficult to motivate because they are more open to express their emotions, but also more prone to arguments. As scientists are a very specific group in society, seeing how they work and studies, and seeing how they find the interest in doing what they do in a country that is well known for its creativity as well as more negative national features is as attractive topic.

This study examines motivation in the academic environment of a small institute - the Center for Theoretical Physics of the Polish Academy of Sciences (small institution, Category A, thirty-five employees, twelve research assistants/Ph.D. students, and a strong internal culture of quality of research) - in order to determine what factors play an important role in motivating doctoral candidates and what is the role of relations between doctoral advisors and candidates in their work. Scientists are a specific group of workers and we wanted to find out what factors they consider important with the hope of improving ways of working with young scientists. This is especially important when taking into account the fact that only about $41 \%$ of Ph.D. candidates in Poland successfully defend their doctoral theses (NIK, 2016).

This study is merely an introduction into more in-depth research on the topic. In it we present our main findings as well as compare the outcomes of the three groups in the sample in order to show the problem from different perspectives and find common points and differences. This description is only valid for scientists in this field of study. They are specific people and the description cannot apply to other scientific faculties and institutions. Further research must be conducted in other institutions for more general conclusions.

\section{Literature Review}

According to Porter (1990) the final stage of country development is an innovation-driven economy, where companies and nations compete through new products, services, and solutions. Managing and motivating 
scientists plays a key role at this stage of the economy. It is their studies and research that form the basis for further innovations (Sapienza, 2004, p. 13). Surprisingly, there are very few publications looking for answers to the question of how to efficiently motivate scientists (e.g., Sapienza, 2004; Jindal-Snape and Snape, 2006). None of them focus on the motivation of young scientists (Ph.D. candidates). This paper aims to fill that gap in the literature of the subject.

One of the most influential theories of human motivation in general was developed by Maslow (1943). Its main assumption is that human needs can be organized into a hierarchy where the more complex, higher needs (e.g., self-actualization) can only be met after lower needs (e.g., physiological needs and safety) are satisfied. Today, Maslow's theory is criticized with respect to (among others) its unidimensional linearity (Rowan, 1999; Yang, 2003). However, it continues to be a useful theoretical framework to work on. It is on the basis of this theory that one might expect doctoral advisors to be located higher in the hierarchy of needs than doctoral students, who are just starting their academic careers. Therefore, one would expect doctoral advisors to be motivated by more transcendent factors (e.g., self-fulfillment). On the other hand, Ph.D. candidates might be more concerned with financial and psychological needs.

Worth mentioning is the fact that some authors have tried to further develop Maslow's theory in order to overcome its weaknesses. One such example is the ERG theory proposed by Alderfer (1969). He suggests a different model that is also based on the assumption of the universality of needs. According to this theory, human needs can be categorized into three groups-existence (encompassing physical and safety needs), relatedness (encompassing belongingness, love, and esteem needs), and growth (encompassing self-fulfillment needs). What is important to bear in mind is that these categories do not have a rigid, hierarchical structure. Thus, it is possible (and natural) for individuals to pursue needs from different categories at the same time. Another important issue that differentiates the two theories is the outcome of need satisfaction. Maslow suggested that the strength of the needs decreases when they are fulfilled. However, Alderfer's research provides empirical arguments that the exact opposite is true-satisfied needs become even more important (Gupta, 2008, p. 49). This conclusion is also very important in the case of scientists, who usually have satisfied needs from all three categories (at least to a certain extent). On the basis of Alderfer's findings one might expect that "lower" needs such as social needs might still be important.

Maslow's theory was also an inspiration for McClelland (1961). He proposed what is known as the Three-Dimensional Theory of Attribution. He 
claimed that there are three main human motivators: a need for achievement, a need for affiliation, and a need for power. One of these three is dominant in the case of each individual and it is because of this that people have different characteristics. For example, employees with a high need for affiliation favor collaboration over competition and do not like uncertainty. One might expect that in a scientific institute the majority of people will have a high need for achievement. For this reason it is important for them to work on ambitious projects.

Another influential motivational theory was developed by Herzberg (1966). He divided factors important to human motivation into two groups: hygiene factors (which minimize dissatisfaction, but have no impact on the motivation of employee) and motivational factors (whose presence motivates people, but their absence does not cause dissatisfaction). This theory can also be applied to the work of scientists. For example, lack of proper equipment would probably be a hygiene factors. Herzberg's theory has been tested in many studies, but one seems especially interesting for this study because it targeted secondary school teacher job satisfaction in Botswana (Sithole and Solomon, 2014). Interestingly, participants in that study indicated that from among hygiene factors the most important are good relationships with administrative staff, other teachers, and pupils, easy access to teaching resources and consumables, and-last but not least-salaries. As to motivation factors, the authors concluded that overall, the sampled teachers are satisfied with their jobs. They are mainly concerned with the passing rates of their pupils and the possibility of participation in the school decision-making process. It would be interesting if similar patterns were observed in the research institute sample.

A successive important theoretical issue is the intrinsic-extrinsic division of motivation. Intrinsic motivation is "the inherent tendency to seek out novelty and challenges, to extend and exercise one's capacities, to explore, and to learn" (Ryan and Deci, 2000, p. 70). Extrinsic motivation, on the other hand, comes from external factors that originate outside of the person, such as cash rewards. We believe that in case of scientists, intrinsic motivation plays a greater role. This assumption is, to some extent, supported in the literature (Jindal-Snape and Snape, 2006, p. 1338).

Another influential theory was proposed by Adams (1963; 1965). In his Equity Theory of Motivation he pointed out that human motivation is influenced by how other employees are rewarded in comparison to their efforts. If the perceived rewards/efforts ratio of other employees is higher than the rewards/efforts ratio of the individual then such a person can be demotivated. Therefore, it is important for employers to keep a fair balance between efforts and rewards in the workplace. We believe 
that this aspect can also be important with respect to scientist and Ph.D. student motivation.

A very intriguing model of human motivation was proposed by Lawler and Suttle (1973). They further developed the work of Vroom (1964). According to their Expectancy Theory, people decide how much effort they put into their jobs. If they find that the expected reward has the right value for them and at the same time the perceived probability of getting the reward is sufficiently high, they will decide to put effort into their jobs. On the other hand, if a possible reward has no meaning for them or the perceived reward probability is low then they are reluctant to invest their energy in the work. Nevertheless, Lawler and Suttle (1973) found that effort alone does not explain employee performance. They suggested that job behavior is also influenced by worker abilities and his or her role perception. Justification for the adding of these two new variables is quite obvious. If employees do not possess the skills needed for the job, work performance will be poor regardless of the amount of effort put into the job. Also, one cannot expect good results if the worker believes that he or she plays other roles in organization than those defined by the organization itself. All these three elements combined have an impact on the employee's performance-crucial with respect to actual rewards (both intrinsic and extrinsic). According to this model, after acquiring the rewards the employee compares actual rewards received to those expected. If received rewards are more than expected then the employee is satisfied and motivated, which will affect effort in a positive way. On the other hand, if the actual rewards are less attractive than expected then motivation will drop. The model just presented has great significance for this research. It suggests that scientist performance is affected by their skills and the consistency of their actual and perceived role in the organization. One might expect that in some cases (especially in the case of Ph.D. candidates) skills might be not be sufficient and perceived role in the organization might be different than the role as defined by the organization. This may lead to dissatisfaction and a drop in the scientist's motivation. This in turn may lead to resignation from studies or leaving a job.

In literature directly addressing the problem of motivation among scientists it is quite common to highlight the role of self-efficacy-i.e. "an individual's judgment of his or her capabilities to perform given actions" (Schunk, 1991, p. 207). This is not surprising if one takes into consideration the fact that scientists (including those who were examined in this research) usually work on ambitious projects. For this reason, without trust in their own capabilities they will become frustrated and demotivated.

Worth mentioning is that there is some interesting research that focuses on scientist motivation to participate in commercialized projects. Some of 
this research draws interesting conclusions that are important for this paper. For example, Lam (2011) found that cash rewards play quite a small role in motivating researchers to engage in commercial projects. Moreover, she found that there are two groups of scientists: traditionalists and entrepreneurial scientists. The first group believes that business and science should be separated and therefore they need clear, external benefits to engage in commercial studies. The second group, on the other hand, believes in the importance of business-science cooperation. Those researchers are mostly driven by intrinsic motivation to participate in such business-oriented projects.

\section{Methodology}

As designed, the survey contained about thirty questions. Three different versions, with only minor differences, for three different groups-doctoral advisors (thirty questions), their students who completed their doctoral studies (twenty-eight questions), and those who, at the time of the survey, were still doctoral candidates (twenty-five questions) - were developed. The largest differences in the surveys were between the surveys for doctoral advisors and both Ph.D. candidates and those who completed their doctoral degrees. The reason for this was that the goal was to ask questions about the same aspects of work, motivation, and relations, but from different perspectives. Thus, questions were adjusted for the groups asked to answer them. The difference in number of questions between the two groups of $\mathrm{Ph}$.D. students was due to the fact that those who completed their studies at that time of the survey were asked three additional questions regarding their overall experiences (e.g., "What made you work as a researcher after completing your studies? and "How do you assess this decision today?"), questions that could not be asked of people who were still studying since they were not applicable. The most important questions asked are presented in Table No. 1.

As this study was conducted in a small institution, there were limited possibilities for finding appropriate respondents. Ultimately, a total eighteen respondents were amassed: seven doctoral advisors and eleven of their students, where out of that eleven, five had completed their studies and six were still studying. This gives a total of 500 answered questions. An attempt was made to reach those who did not complete their studies, for whatever reasons. However, they did not agree to complete the survey. Because of this there are no data from people who were not able to make it through the whole process of being awarded a doctoral degree. This has to be acknowledged when analyzing the results and it is for this reason that 
no comparisons were made between those who completed their studies and those who did not. No analysis was conducted of resultant potential problems. This is a serious limitation of the study that could not be overcome at this stage of the study. The reason behind this problem is that people who fail in something are less likely to share their experience with others.

Table No. 1. Examples of questions asked in the survey, divided into three groups of participants (Translation from the Polish)

\begin{tabular}{|c|c|c|c|}
\hline No. & Doctoral advisors & $\begin{array}{l}\text { Completed Ph.D. } \\
\text { students (doctors) }\end{array}$ & Current Ph.D. students \\
\hline 1. & $\begin{array}{l}\text { Why did you choose a ca- } \\
\text { reer in research? }\end{array}$ & $\begin{array}{l}\text { Why did you choose a ca- } \\
\text { reer in research? }\end{array}$ & $\begin{array}{l}\text { Why did you choose a ca- } \\
\text { reer in research? }\end{array}$ \\
\hline 2. & $\begin{array}{l}\text { Please describe how you } \\
\text { usually choose your doc- } \\
\text { toral students. }\end{array}$ & $\begin{array}{l}\text { Please describe why and } \\
\text { under what circumstances } \\
\text { you chose this particular } \\
\text { person to be your Ph.D. su- } \\
\text { pervisor. }\end{array}$ & $\begin{array}{l}\text { Please describe why and } \\
\text { under what circumstances } \\
\text { you chose this particular } \\
\text { person to be your Ph.D. su- } \\
\text { pervisor. }\end{array}$ \\
\hline 3. & $\begin{array}{l}\text { Please describe the typical } \\
\text { course work for preparing } \\
\text { a doctoral thesis under } \\
\text { your direction. }\end{array}$ & $\begin{array}{l}\text { Please describe the future } \\
\text { course of your Ph.D. re- } \\
\text { search. }\end{array}$ & $\begin{array}{l}\text { Please describe the future } \\
\text { course of your Ph.D. re- } \\
\text { search. }\end{array}$ \\
\hline 4. & $\begin{array}{l}\text { In your opinion, what traits } \\
\text { should doctoral students } \\
\text { have? }\end{array}$ & $\begin{array}{l}\text { What was a problem in } \\
\text { your research and what was } \\
\text { a pleasant surprise? }\end{array}$ & $\begin{array}{l}\text { What has turned out to be } \\
\text { a problem in your research } \\
\text { and what has turned out } \\
\text { to be a pleasant surprise? }\end{array}$ \\
\hline 5. & $\begin{array}{l}\text { What requirements do you } \\
\text { have for Ph.D. students- } \\
\text { high or low? }\end{array}$ & $\begin{array}{l}\text { What requirements, in } \\
\text { your opinion, do you hold } \\
\text { yourself to-high or low? }\end{array}$ & $\begin{array}{l}\text { What requirements, in } \\
\text { your opinion, do you hold } \\
\text { yourself to-high or low? }\end{array}$ \\
\hline 6. & $\begin{array}{l}\text { What was, in your opin- } \\
\text { ion, the student's belief } \\
\text { about their influence on } \\
\text { the course of work: did he/ } \\
\text { she independently decide } \\
\text { what steps are to be taken } \\
\text { next or passively rely on } \\
\text { your suggestions? }\end{array}$ & $\begin{array}{l}\text { How has your belief re- } \\
\text { garding your own impact } \\
\text { on the effectiveness of } \\
\text { your doctoral dissertation } \\
\text { changed? }\end{array}$ & $\begin{array}{l}\text { If work on your doctor- } \\
\text { ate made you feel negative } \\
\text { emotions (or have negative } \\
\text { associations), what were } \\
\text { they and what stages/ele- } \\
\text { ments did they involve? }\end{array}$ \\
\hline 7. & $\begin{array}{l}\text { To what degree did you } \\
\text { feel responsible for the } \\
\text { course (and success) of } \\
\text { the Ph.D. student's work? }\end{array}$ & $\begin{array}{l}\text { If work on your doctor- } \\
\text { ate made you feel negative } \\
\text { emotions (or have negative } \\
\text { associations), what were } \\
\text { they and what stages/ele- } \\
\text { ments did they involve? }\end{array}$ & $\begin{array}{l}\text { If work on your doctor- } \\
\text { ate made you feel negative } \\
\text { emotions (or have negative } \\
\text { associations), what were } \\
\text { they and what stages/ele- } \\
\text { ments did they involve? }\end{array}$ \\
\hline
\end{tabular}




\begin{tabular}{|c|c|c|c|}
\hline 8. & $\begin{array}{l}\text { What do you think would } \\
\text { have to have happened for } \\
\text { you to suggest that your } \\
\text { doctoral student should re- } \\
\text { sign from his or her doc- } \\
\text { toral dissertation and look } \\
\text { for another job? Has such } \\
\text { a situation ever occurred? }\end{array}$ & $\begin{array}{l}\text { What factors could have } \\
\text { caused you to resign from } \\
\text { work on your doctorate } \\
\text { in the given field and find } \\
\text { another job? }\end{array}$ & $\begin{array}{l}\text { What factors could cause } \\
\text { you to resign from work on } \\
\text { your doctorate in the given } \\
\text { field and find another job? }\end{array}$ \\
\hline 9. & $\begin{array}{l}\text { If you had the impression } \\
\text { that the doctoral student } \\
\text { was having difficulties and } \\
\text { did not have a chance of } \\
\text { completing the work, what } \\
\text { type of information would } \\
\text { you provide? }\end{array}$ & $\begin{array}{l}\text { If you discovered or some- } \\
\text { one suggested that comple- } \\
\text { tion of a doctoral degree } \\
\text { faces a barrier that is dif- } \\
\text { ficult or almost impossible } \\
\text { to overcome, how would } \\
\text { you react? }\end{array}$ & $\begin{array}{l}\text { If you discovered or some- } \\
\text { one suggested that comple- } \\
\text { tion of a doctoral degree } \\
\text { faces a barrier that is dif- } \\
\text { ficult or almost impossible } \\
\text { to overcome, how would } \\
\text { you react? }\end{array}$ \\
\hline 10. & $\begin{array}{l}\text { To what extent do your ex- } \\
\text { pectations regarding your } \\
\text { doctoral student's work } \\
\text { and its effects reflect real- } \\
\text { ity? What are the biggest } \\
\text { disparities? }\end{array}$ & $\begin{array}{l}\text { To what extent did the } \\
\text { images at the beginning } \\
\text { of doctoral work overlap } \\
\text { with the actual course of } \\
\text { the work, and if they did } \\
\text { not, how did they differ? }\end{array}$ & $\begin{array}{l}\text { To what extent did the } \\
\text { images at the beginning } \\
\text { of doctoral work overlap } \\
\text { with the actual course of } \\
\text { the work, and if they did } \\
\text { not, how did they differ? }\end{array}$ \\
\hline 11. & $\begin{array}{l}\text { What is the degree of diffi- } \\
\text { culty of the issues proposed } \\
\text { for the thesis? Why were } \\
\text { such issues selected? }\end{array}$ & $\begin{array}{l}\text { What is the degree of dif- } \\
\text { ficulty of issues undertaken } \\
\text { in your thesis? }\end{array}$ & $\begin{array}{l}\text { What is the degree of dif- } \\
\text { ficulty of issues undertaken } \\
\text { in your thesis? }\end{array}$ \\
\hline 12. & $\begin{array}{l}\text { What style of collaboration } \\
\text { with the doctoral student } \\
\text { do you consider best? } \\
\text { Please describe. }\end{array}$ & $\begin{array}{l}\text { What style of collabora- } \\
\text { tion with the doctoral ad- } \\
\text { visor do you consider best? } \\
\text { Please describe. }\end{array}$ & $\begin{array}{l}\text { What style of collabora- } \\
\text { tion with the doctoral ad- } \\
\text { visor do you consider best? } \\
\text { Please describe. }\end{array}$ \\
\hline 13. & $\begin{array}{l}\text { How did you encourage } \\
\text { your student to solve prob- } \\
\text { lems independently if they } \\
\text { occurred? }\end{array}$ & $\begin{array}{l}\text { With whom, besides your } \\
\text { doctoral advisor, did you } \\
\text { discuss your ideas? To what } \\
\text { extent were these conversa- } \\
\text { tions helpful? }\end{array}$ & $\begin{array}{l}\text { With whom, besides your } \\
\text { doctoral advisor, do you } \\
\text { discuss your ideas? To what } \\
\text { extent are such conversa- } \\
\text { tions helpful? }\end{array}$ \\
\hline 14. & $\begin{array}{l}\text { What contacts do you } \\
\text { maintain with your doc- } \\
\text { toral students after their } \\
\text { defense and awarding of } \\
\text { their doctorate? }\end{array}$ & $\begin{array}{l}\text { What prompted you to } \\
\text { work in science after } \\
\text { completing your doctor- } \\
\text { ate? How do you judge this } \\
\text { decision today? }\end{array}$ & \\
\hline 15. & $\begin{array}{l}\text { How do you assess the } \\
\text { time spent together with } \\
\text { a doctoral student in the } \\
\text { preparation of his or her } \\
\text { doctoral thesis? }\end{array}$ & $\begin{array}{l}\text { In retrospect, how do you } \\
\text { assess the time spent in } \\
\text { preparing your doctoral } \\
\text { thesis? Please provide } \\
\text { a broader statement. }\end{array}$ & \\
\hline
\end{tabular}

Source: Own study. 
All people surveyed were working at the institute at the time (or worked there during theirs studies and left later). The investigated institute hires its doctoral candidates as assistant researchers so "they do not have to worry about not having money for a living" (as stated by the institute director). As this is a small institute, its employees have close relations with each other. However, there are some exceptions that will be discussed later. There are also some employees who do not work as researchers. Nevertheless, as only scientists were targeted in this study, non-scientists were not included (although relations between them and scientists can also have an impact on the scientists' work, as the proper work of administrative staff is important in creating good atmosphere in the workplace and efficient workflows).

The survey was sent to all respondents who had previously agreed to participate in the study. Each participant was asked to fill out an on-line form ("Google Forms" was used due to its convenience and easy access to collected data) that had been created separately for each person. This made it possible to identify who sent the specific answer and match professors with their students, comparing their answers. All people who were asked to complete the form did so within a week. This should be considered a reasonably prompt response indicating the high engagement of participants in this study. Subsequently, all answers were put in a single file facilitating the comparing of the answers of doctoral advisors and their students. In order to analyze the data, the method used involved the counting of keywords in parallel with reading and interpreting what was said by participants in the survey. A decision was taken to use these two methods simultaneously as it was hoped this could lead to more robust outcomes.

Occurrences of words were counted, but considering their context so that they would not be counted in the wrong category. The words were assigned to six main categories. This emerged somewhat naturally and was related to motivation. Each of these six categories was divided into two more-words with positive and words with negative context/meaning. The main categories included scientific motivation (motivation stemming from scientific interests), intrinsic motivation, motivation for personal development, atmosphere (in work and in general), evaluating words (just positive or negative, but not related to previous categories), and personal motives.

Sums of words were counted for each separate category and compared with previous assumptions made to the groups. This was followed by a comparison of the outcomes of the two groups-doctors/doctoral candidates and their doctoral advisors. The doctoral candidates and doctors were analyzed together as one group. It turned out during the first reading of the answers that they share a lot of experiences and joining them into a single group actually facilitates comparison. Therefore, despite the doctoral candidates and 
doctors having a different number of questions, they were not compared as two different groups, but were considered as one in the keyword counting.

At the same time, each survey was analyzed thoroughly and general observations were noted for all of them. This was followed by an analysis of data obtained applying different psychological perspectives and theoretical frameworks of motivation. It was important not to rely on word counting alone, as this is not an ideal method and not all questions had been totally neutral, forcing the interpretation of information concerning the question asked as well as the ways it was formulated.

\section{Research and Results}

We deliberately decided against formulating formal hypotheses, as we did not want to bias interpretations made during work with the answers. Nevertheless, results were quite surprising. Below, in Tables No. 2 and No. 3 , is a presentation of the summary of the word counting (only main categories are shown).

Table No. 2. Word count subdivided by main category—-the doctoral advisor group

\begin{tabular}{|c|c|c|c|c|c|}
\hline \multicolumn{7}{|c|}{ Doctoral advisors } \\
\hline $\begin{array}{c}\text { Scientific } \\
\text { motivation }\end{array}$ & $\begin{array}{c}\text { Intrinsic } \\
\text { motivation }\end{array}$ & $\begin{array}{c}\text { Motivation } \\
\text { for personal } \\
\text { development }\end{array}$ & Atmosphere & $\begin{array}{c}\text { Evaluating } \\
\text { words }\end{array}$ & $\begin{array}{c}\text { Personal } \\
\text { motives }\end{array}$ \\
\hline \multicolumn{7}{|c|}{ Positive } \\
\hline 67 & 28 & 64 & 124 & 69 & 62 \\
\hline \multicolumn{7}{|c|}{ Negative } \\
\hline 2 & 19 & 17 & 28 & 24 & 14 \\
\hline
\end{tabular}

Source: Own study.

On the basis of analyzed literature (e.g., Mitchell and Mickel 1999, p. 568570; Lea and Webley, 2006), it may be assumed that financial factors should be an important motivator (especially for Ph.D. candidates). Surprisingly, participants rarely mentioned money or other financial aspects. For this reason this category does not appear in Table No. 2 or Table No. 3. Only one person suggested that he should be paid more, and that person also mentioned that his work was not as satisfying as he thought it would be. 
Table No. 3. Word count subdivided by main category - the doctoral candidate group

\begin{tabular}{|c|c|c|c|c|c|}
\hline \multicolumn{6}{|c|}{ Doctoral candidates } \\
\hline $\begin{array}{l}\text { Scientific } \\
\text { motivation }\end{array}$ & $\begin{array}{l}\text { Intrinsic } \\
\text { motivation }\end{array}$ & $\begin{array}{l}\text { Motivation } \\
\text { for personal } \\
\text { development }\end{array}$ & Atmosphere & $\begin{array}{c}\text { Evaluating } \\
\text { words }\end{array}$ & $\begin{array}{c}\text { Personal } \\
\text { motives }\end{array}$ \\
\hline \multicolumn{6}{|c|}{ Positive } \\
\hline 80 & 11 & 49 & 140 & 59 & 31 \\
\hline \multicolumn{6}{|c|}{ Negative } \\
\hline 27 & 33 & 10 & 28 & 15 & 24 \\
\hline
\end{tabular}

Source: Own study.

It also turned out that in both groups (doctoral advisors and doctoral candidates and doctors combined) the category with the highest number of words was a category called "atmosphere" (which contains, among other things, relations between doctoral advisors and Ph.D. candidates as well as relations with other coworkers). When words considered as positive were counted, this same category had the most words in the doctoral advisor group in words considered negative, where in the doctor/doctoral candidate group most of the words fell into the "intrinsic motivation" category, but the "atmosphere" category was second with the most words. It has to be stressed that these categories do not have the same breadth, and some words could be counted twice as they matched more than one category. However, this could make outcomes difficult to interpret, so it was decided to assign one word to only one category on the basis of the context in which it was used. All in all, there were only a few such words. Therefore, they have a negligible impact on final outcomes. Furthermore, it was decided that words that had ambiguous meanings and could not be assigned to a category on the basis of the context in which they occurred should be excluded from the analysis, even if they had an emotional subtext. Yet, in this case as well, the number of such words was small.

Summing up, surprisingly, positive work atmosphere was the most common topic in all the answers. Curiosity and intrinsic motivation were also important, yet those factors appeared less frequently.

A thorough analysis of all answers also leads to interesting conclusion. First and foremost, it seems that it confirms the conclusions drawn from word-counting. Working atmosphere was indicated as an important factor for most respondents. For example, one professor claimed, "Administrative staff plays an important role in creating proper atmosphere. On the one 
hand, Ph.D. students should not feel additional stress when they need to take care of formalities. On the other, they have to learn how we do various things and they need to be communicative-not only with respect to scientific matters, but also in everyday issues." Moreover, one of the doctoral candidates pointed out, "It was a pleasant surprise that most, if not all, employees of the institute were so friendly." Yet, not all the statements were positive-e.g., other respondent complained, "Compared to other workgroups in the institute, there is a lack of atmosphere for loose talks related to various topics. I think that such conversations help find new ideas for our scientific work."

A thorough analysis also provides some supporting arguments regarding the importance of curiosity, scientific interests, and intrinsic motivation in the academic environment. One of the respondents said, "I have always wanted to 'know everything' and it seemed to me that a scientific career would allow me to get as close as possible to this ideal." Other respondents pointed out that they chose a scientific career because (among others):

a) Physics had always been their passion;

b) Science is interesting and provides freedom, moreover, it provides opportunities to meet interesting people;

c) In the previous political system, the scientific worker could be spiritually relatively independent.

At the same time, a thorough analysis of answers made it possible to distinguish two groups of doctoral advisors and two groups of their students. It turned out that, in most cases, doctoral advisors belong to the group that can be described as "active" or to another one described as "passive." "Active" doctoral advisors encouraged their students, giving them various tasks and problems to solve. In general, they claim that it is important to have close relations with their students in order to guide them along the entire path of becoming a scientist. In contrast, "passive" doctoral advisors indicated that students are adults and should know what to do and where to go on their own, addressing their doctoral advisor only when they come up against major problems. There was similar division among students - one group wanted to be guided by an engaged doctoral advisor, while the other wanted to do their research and work mostly on their own. What was especially interesting was to find pairs of participants whose working styles did not match (e.g., an "active" doctoral advisor and a "passive" student). In such cases it was found that respondents (especially Ph.D. candidates) expressed doubts and negative thoughts more frequently. On the other hand, when the working styles of the doctoral advisor and student were the same, students were clearly more positive about their work and research. 
It seems that in a delicate job such as creative thinking, good relations play an important role. Thus, when they are negative because of discrepancies between what the student needs and what his or her professor can provide, this usually leads to a decrease in motivation and dissatisfaction. Yet, if the expectations of the Ph.D. candidate and the attitude of his or her doctoral advisor match, one observes increased motivation for further scientific work.

A thorough analysis of answers also confirmed the conclusions drawn from word counting-positive work atmosphere, intrinsic motivation, and curiosity seem to play an important role in motivating scientists, especially young ones (Ph.D. candidates).

\section{Discussion of the Results}

There are several interesting conclusions that can be derived from this study. Most of them are quite surprising. It should be expected that curiosity and intrinsic motivation are the most important factors for scientists and, for this reason, they should be referred to the most frequently by them, as scientist are often seen as people driven mostly by their own need of knowing more about the world. Surprisingly, instead of curiosity, this study shows that work atmosphere is the most common topic. Respondents often talked about how important relations with their coworkers are. On the basis of these outcomes it is possible to draw a recommendation: managers of scientific institutes and universities should not ignore the necessity of building positive atmosphere in the workplace.

Nevertheless, survey outcomes confirm that the scientists from the sample are, to a large extent, motivated by their own curiosity, scientific interests, and intrinsic motivation. This is consistent with existing literature on the subject and the conclusions of other studies. Obviously, this should be implemented in human resource management in scientific institutions.

There was also another quite surprising and interesting result: participants in the study said almost nothing about money. Taking into consideration the fact that wages in Polish science institutions are generally not high, it is surprising that only one out of eighteen participants complained about this fact. However, that person did so it in such gentle words that it seems it was not a vital issue. This observation may lead to an interesting conclusion. Financial factors do not play an important role in motivating scientists (at least in the case of the sample). This might be the reason why the wages in Polish science institutes and universities are relatively low compared to the private sector or even to other public institutions such as schools. Since 
it is not a major motivational factor, then the pressure on the government is naturally lower. Of course, one should take into consideration the fact that the examined institute has wages that are above average (due to grants received) and the financial situation of Ph.D. candidates is stable because they are employed as employees of the institute. Average Ph.D. students in the best-case scenario receive scholarships that are awarded each year and so, are relatively uncertain sources of income. This problem might be interesting to explore in further research.

Another interesting conclusion can be drawn from this study upon application of the Pyramid of Needs as created by Abraham Maslow (in spite of the flaws of this concept it is still useful) to the analysis. It seems logical that doctoral advisors in the sample should be placed on the highest possible level of the Pyramid-they most clearly expressed needs for self-actualization. On the other hand, doctors/doctoral candidates should be placed between the need for love and belonging and the need for esteem. These observations are not surprising. Doctoral advisors mostly consists of very experienced people who have probably already met their lower needs and can focus on thinking about new ways of expressing themselves. In contrast, the group of doctors/doctoral candidates consists mostly of inexperienced, young people who are still seeking their place in the world. Therefore, they still need to find out where they belong, with whom they want to spend the rest of their lives, and still have to earn respect. They are trying to fulfill these needs first before they can get to the level of their professors.

Application of the Herzberg approach was also tried on the data. However, this proved difficult as the main analyzed factor-work atmosphere (especially in case of relationships between doctoral advisors and Ph.D. candidates) — can be classified both as a hygienic factor and as a motivational factor, depending on the situation. For example, doctoral candidates who claim that their collaboration with their doctoral advisors is proper are usually highly motivated. In contrast, students who found that their collaboration with their professors is not proper seem to be dissatisfied. It is possible that there exist some minimum requirements relating to work atmosphere that, if not met, result in dissatisfaction. Yet, if the work atmosphere is extraordinarily positive, then this may increase the motivation of employees.

This also leads to another important conclusion from this research: In the case of Ph.D. students' motivation for scientific work, it is crucial that their needs and expectations match theirs doctoral advisors' working style. This study has easily distinguished between the two working styles of doctoral advisors- "active" and "passive." In an ideal situation, the student should be given exactly what he or she needs from the doctoral advisor. In practice, such personality traits are rarely taken into consideration (the 
most important criterion is fitness of the scientific interests of the candidate and doctoral advisor). This might be one of the main reasons why so many $\mathrm{Ph} . \mathrm{D}$. candidates do not finish their studies. Moreover, in practice, it is quite unusual to change one's doctoral advisor during studies (in spite of there being such a formal possibility). Of course, a student can somehow adjust to the doctoral advisor's requirements and working style, but sometimes this is simply ineffective and leads to the leaving of the Ph.D. program by such a student. One of the doctoral advisors clearly said that he rids himself of students he does not like. This can be an issue because it does not necessarily mean that such students are not good scientist.

\section{Limitations and Further Research}

The presented research has certain limitations. Being a qualitative study conducted in a specific institute, the conclusions should not be extrapolated to other institutions of science (especially those working in disciplines other than physics). This is why further research should investigate if similar patterns might be observed in other institutes and universities.

Another limitation of this study is the fact that the sample does not encompass doctoral students who left their Ph.D. program before finishing it. Future studies should also add such people to the sample, although it must be borne in mind that this might not be an easy task.

\section{References}

Adams, J.S. (1963). Toward an Understanding of Inequity. Journal of Abnormal and Social Psychology, 67, 422-436.

Adams, J.S. (1965). Inequity in Social Exchange. In: L. Berkowitz (Ed.), Advances in Experimental Social Psychology (Vol. 2, pp. 267-299). New York: Academic Press.

Alderfer, C.P. (1968). An Empirical Test of a New Theory of Human Needs. Organizational Behavior and Human Performance, 4(2), 142-175.

Gupta, S.S. (2008). Managerial Skills: Explorations in Practical Knowledge. New Delhi: Global India Publications.

Herzberg, F. (1966). Work and the Nature of Man. Cleveland: World Publishing Co.

Hrebickova, M. and Graf, S. (2014). Accuracy of National Stereotypes in Central Europe: Outgroups Are Not Better than Ingroups in Considering Personality Traits of Real People. European Journal of Personality, 28(1), 60-72.

Jindal-Snape, D. and Snape, J.B. (2006). Motivation of Scientists in a Government Research Institute: Scientists' Perceptions and the Role of Management. Management Decision, 44(10), 1325-1343. 
Lam, A. (2011). What Motivates Academic Scientists to Engage in Research Commercialization: "Gold," "Ribbon" or "Puzzle"? Research Policy, 40(10), 1354-1368.

Lawler, E.E. and Suttle, J.L. (1973). Expectancy Theory and Job Behavior. Organization Behavior and Human Performance, 9, 482-503.

Lea, S.E.G. and Webley, P. (2006). Money as Tool, Money as Drug: The Biological Psychology of a Strong Incentive. Behavioral and Brain Sciences, 29(2), 161-176.

Maslow, A. (1943). A Theory of Human Motivation. Psychological Review, 50(4), 370-96.

McClelland, D.C. (1961). The Achieving Society. Princeton, New Jersey: Van Nostrand.

Mitchell, T.R. and Mickel, A.E. (1999). The Meaning of Money: An Individual-Difference Perspective. Academy of Management Review, 24(3), 568-578.

NIK. (2015). Kształcenie na studiach doktoranckich [Education in doctoral studies]. Warsaw: Department of Science, Education, and National heritage of the NIK Supreme Audit Office.

Porter, M.E. (1990). The Competitive Advantage of Nations. New York: Macmillan.

Rowan, J. (1999). Ascent and Descent in Maslow's Theory. Journal of Humanistic Psychology, 39(3), 125-133.

Ryan, R.M. and Deci, E.L. (2000). Self-Determination Theory and the Facilitation of Intrinsic Motivation, Social Development, and Well-Being. American Psychologist, 55(1), 68-78.

Sapienza, A.M. (2004). Managing Scientists: Leadership Strategies in Scientific Research. New York: Wiley-Liss.

Schunk, D.H. (1991). Self-Efficacy and Academic Motivation. Educational Psychologist, 26(3/4), 207-231.

Sithole, B. and Solomon, G. (2014). Business Studies Teachers' Satisfaction with Their Work: An Application of Herzberg's Two Factor Theory. International Journal of Science Education, 6(3), 435-444.

Vroom, W.H. (1964). Work and Motivation. New York: Wiley.

Yang, K.S. (2003). Beyond Maslow's Culture-Bound Linear Theory: A Preliminary Statement of the Double-Y Model of Basic Human Needs. Nebraska Symposium on Motivation, 49, 175-255. 


\author{
Andżelika Dzięgiel* \\ Patrycja Gulak-Lipka**
}

\title{
Development of the Entrepreneurial Qualities of Athletes in Selected Sport Disciplines
}

This article aims at identifying the entrepreneurial qualities of athletes in selected sport disciplines. Countless articles and studies point to the fact that athletes make up a valuable asset on the roster of many companies. Athletes have a great set of traits that many employees seek, including dedication to work. Most studies focus on this subject from the point of view of the employer.

An individual sport and a team sport-athletics and basketball-were selected for the research and analysis. The results of this research show which entrepreneurial qualities are best developed in athletes with an indication to the sport discipline that they practice. Results make it possible to distinguish among significant differences in the set of entrepreneurial qualities acquired during a sporting career. Moreover, the study demonstrates that individual sport athletes are more predisposed to start their own businesses, while the vast majority of team sport athletes have a greater ability to cooperate with others than those originating from individual sports. This information should prove important for companies that are focused on team projects. What is more, the study confirms the assumption that the success of an athlete translates into success as an entrepreneur.

Keywords: entrepreneurial qualities, athlete, basketball player.

\section{Rozwój właściwości przedsiębiorczych sportowców $z$ wybranych dyscyplin sportowych}

Celem artykułu jest identyfikacja przedsiębiorczości sportowców wybranych dyscyplin sportowych. Liczne artykuły oraz badania wskazują, iż sportowiec to wartościowy nabytek dla wielu firm. Sportowcy posiadają szeroką gamę cech poszukiwanych przez pracodawców, w tym poświęcenie do pracy. Większość badań koncentruje się na tym temacie, biorąc za odniesienie punkt widzenia pracodawcy.

Badaniom i analizie poddano sport indywidualny - lekkoatletykę oraz sport zespołowy - koszykówkę. Wyniki badań wykazują, które właściwości przedsiębiorczości są najlepiej

\footnotetext{
* Andżelika Dzięgiel, Ph.D. Candidate - Faculty of Economic Sciences and Management, Nicolaus Copernicus University, Toruń, Poland; e-mail: dziegiel@doktorant.umk.pl.

** Patrycja Gulak-Lipka, Ph.D. Candidate - Faculty of Economic Sciences and Management, Nicolaus Copernicus University, Toruń, Poland; e-mail: pgl@doktorant.umk.pl.
} 
rozwijane przez sportowców z uwzględnieniem ich dyscypliny sportowej. Rezultaty pozwalają pokazać znaczące różnice w postawach przedsiębiorczych nabytych w trakcie kariery sportowej. Ponadto, badania pokazują, że sportowcy uprawiający sport indywidualny są bardziej skłonni do założenia własnych firm. Za to zdecydowana większość sportowców z dyscyplin zespołowych posiada zdolność współpracy w grupie. Jednocześnie, badanie wykazało słuszność założenia, iż sukces sportowca przekłada się na sukces przedsiębiorcy.

Słowa kluczowe: właściwości przedsiębiorcze, sportowiec, koszykarz.

JEL: Industrial Organization

\section{Introduction}

Effective functioning in today's world, where a market economy rules, requires citizens to be versatile and display certain characteristics that may be crucial for the success of an individual in both personal and professional life. The reality of today requires people to adopt an active and very often creative attitude, not wait for ready-made solutions and opportunities. Hence, it may come to be that individuals will have to rely on themselves as well as on qualities developed thanks to previous experience.

The ability to seize opportunities as well as creativity, innovation, initiative, and openness-universal qualities most frequently mentioned by many authors-constitutes what may be called an entrepreneurial human being. In addition to creativity and entrepreneurship there is also the ability to learn how to stimulate the development of companies over the centuries (Wójcik, 2014). Due to the fact that the concept of entrepreneurship has many possible meanings, it is hard to provide a finite and universal list of the characteristics of people who can be described as being "entrepreneurial." As the world changes, this list of features evolves and differentiates depending on civilizational, cultural, social, economic, and legal conditions (Bednarczyk and Nessel, 2016). This indicates that the environment in which people function, together with the many areas of their lives, has a significant impact on the best entrepreneurial features.

The purpose of this article is to identify the characteristics of entrepreneurs that are developed by athletes during their sporting careers-features that upon concluding that career facilitate functioning on the labor market and in the business world. Moreover, this article strives to evaluate and identify the differences that characterize individual and team athletes. The two main sports that were analyzed are athletics and basketball, but the study was supplemented by information gathered from other team (volleyball) and individual sports (the triathlon). 
It is possible to identify certain universal components that characterize the entrepreneurial behavior of people and organizations. There are four such components:

- Sensitivity to change - proactive behavior,

- Innovation - creativity and the introduction of new products,

- A willingness to take risks, and

- A readiness to learn.

Sensitivity to change is a conscious response to transformation in the near (but not only) environment. This requires an active anticipating and predicting of events that give direction to changes that influence the future. In addition, it involves the ability to seize opportunities for implementing new ideas. Innovation demonstrates the degree to which people and organizations are engaged in the creation of new ventures and actions producing new or improved products and services, processes and organizational systems. The willingness to take risks is expressed in commitment to a project whose effects are not known. The effects of risk in the event of failure of a new idea can be negative-e.g., the loss of a position or even work. Readiness to learn requires constant improvement in a dynamically changing environment. Improvement of skills and development of knowledge should involve lower-level employees, managers, and all legal entities (Bednarczyk and Nessel, 2016).

Entrepreneurship relies heavily on discovering new horizons, addressing challenges, and seizing opportunities in the changing economic environment (Koster and Plum, 2012). To put it simply, entrepreneurship is associated with constant risk, which can give tangible results in the form of filling a market gap and enjoying the resultant profit.

As to the willingness to take risks, clearly not all entrepreneurs are willing to accept a higher level of risk. After all, uncertain and risky situations are associated with decision-making and actions undertaken in cases of uncertainty as to final consequences. E. Weber has demonstrated certain changing attitudes towards risk. In her research she presented them with respect to area of life and gender. It appears that men are more willing to take risks in almost all areas (areas considered included financial, ethical, health, social, and recreational activities), but not in the social sphere (Weber, Blais, and Betz, 2002).

It is possible to list a few universal competencies defining entrepreneurial attitudes on the basis of research into the requirements of Polish employers in the recruitment process. One of the researchers mentioned six competences-creativity, cooperation with others, communication, work organization, analytical skills, and use of workplace equipment (Danielewicz, 2014). At the same time, openness to innovation, different views, and people from 
different countries is a major factor in the development of enterprises in the Netherlands (Glinka, 2015).

Among the modern definitions of entrepreneurship, it is Kalantaris' definition (2004) that attracts attention. He sees entrepreneurship as an activity that combines a number of important factors with each other, thus creating a network of production and distribution:

- Production factors,

- Contracts with other entrepreneurs, and

- Contracts with other economic actors.

In his opinion, an entrepreneur has a special ability to control all activities connected with his or her business. Moreover, an entrepreneur is able to realize and make complex decisions for the whole company under different conditions (Koster and Plum, 2012).

Among contemporary authors interested in the subject of entrepreneurship, there are those who associate entrepreneurship with a kind of creativity. According Johannisson (2005), the entrepreneur is an innovator who, in a sense, questions adopted methods and the perception of the world, takes the initiative, and acts in an unconventional manner. What follows is that the entrepreneur is not afraid of uncertainty and even consciously wades into it.

Table No. 1. Entrepreneurial Competencies

\begin{tabular}{|l|l|}
\hline \multicolumn{2}{|c|}{ The entrepreneur as a person who has the following competencies: } \\
\hline - Innovation & - Perseverance \\
\hline - Search for information & - Confidence \\
\hline - Awareness of quality & - Ability to persuasion \\
\hline - Commitment to work & - Assertiveness \\
\hline - Proper planning & - Tracking opportunities \\
\hline
\end{tabular}

Source: Own work based on the EDI Report at http://ediindia.org/e-reports/ (accessed on November 10, 2016).

Even though there is no finite number of qualities that the most successful businessman possesses, every now and then researchers and research institutes attempt to specify what constitutes an exemplary entrepreneurial profile for the current market environment and economic situation. For example, one of the results of a recent study published in EDI Reports 2016 is a set of entrepreneurial competencies (Table No. 1.). However, it is necessary to distinguish between qualities or personality features and 
competencies. Personality is a set of psychological traits characteristic of every human being. These features are mostly inherited, but they are also influenced by the environment in which a person lives. On the other hand, competencies in different areas are learned. Entrepreneurial competencies describe the ability to act, predict, solve, improve, reconcile, and decide.

Finally, John Greathouse, a professor at the University of California in Santa Barbara, believes that entrepreneurship is best learned experientially and that business expertise is acquired in a manner similar to learning athletic skills (Greathouse, 2015). It is always possible to gain a great deal of useful knowledge by reading books, watching videos, and talking with experts about how to score a point, kick a soccer ball, or serve a volleyball, but until an individual gets on the actual playing field or court, he or she will never gain the requisite skills and competences to master the game. What he means is that it is possible to acquire the right qualities and learn how to be a great entrepreneur, but studying theory and cases discussing successful business stories is not the way to do it. It is only through a process of learning practical skills in the field of interest or where the opportunities are that this can be achieved.

According to Mruk (2006), the functioning of the spheres of sport and business have a lot of planes that interact and complement each other. What is more, investing in strengths, both in sport and in business, enhances development. For example, development of an athletic talent is possible if it involves the enduring engagement of both coach and player. One can view the company in a similar vein. It should strive to recognize the abilities of employees and develop them in systematic way. Additionally, Mruk (2006) emphasized that emotional intelligence and concentration is a prerequisite for success in business. For its part, good performance in sports is associated with the ability to concentrate and master emotion.

The majority of athletes, regardless of the sport discipline, commit years to work toward achieving their dreams on the field, on the court, or in the gym. Their commitment is derived from short-term goals such as having a good week of practice, staying fit and healthy, and winning the next match as well as long-term goals such as qualifying for the playoffs, winning a championship, or earning an invitation to play for the national team. Such an attitude demonstrates a great deal of determination, discipline, perseverance, and regularity.

Only the outstanding sport personalities will have a great career crowned with trophies and lucrative advertising contracts. The rest are not as talented, lucky, successful, or suffer from injuries that prevent them from continuing their athletic careers. However, being on top and a part of the professional sporting world, even for a short period of time, gives an athlete 
a great insider view on how to efficiently navigate in the business environment. One of the most important things athletes learn during their career is seeing what is possible in life when they fully commit to their vision and pursue their goals with great passion.

Moreover, some psychologists have observed an analogy between the mind of an athlete and that of a businessman. It turns out that they share a strong need to win. Both athletes and business executives rely on improving their skills as the way to achieve their objectives. It is determination, strength of character, and willingness to fight that play a huge role in the fight for the podium in both sport and business. The billionaire Mark Cuban found that the most important ingredients of success are effort and sweat. Hence, it is not only the success that is important, but also the road to achieving it. ${ }^{3}$

"Anything is possible" is often heard, something of a motto among athletes. It means that athletes believe that they are capable of achieving nearly everything they desire. This proves the greatness of most athletes and makes them a desirable investment for many entrepreneurs who could be their potential employer or companies that use the image of an athlete for marketing purposes. The best example comes from the Nike Corporation and their cooperation with Michael Jordan. Nike is a sporting goods company and it is pretty obvious that it reaches out for services of athletes. However, according to Phil Knight, the CEO of the Nike Corporation: not of any athlete. His words perfectly sum this view up: "You can't explain much in sixty words, but when you show Michael Jordan, you don't have to."

There is an opinion throughout the professional and business world that whoever has had a chance to work with a former athlete knows that it is easier to train former athlete employees because they are used to the need for constant adjustment to the situation on the court or field, whether during practice or a game (Howes, 2015). In the United States many employers and entrepreneurs recruit on campus, where this relationship extends onto potential candidates for employment who successfully combine studying and sports. Many CEOs value their dedication, experience, and willingly employ them in their corporations, entrusting them with very responsible positions and duties. Furthermore, their interest in hiring athletes extends well beyond the usual clichés of teamwork and competitive instincts. What is interesting is that the American psychologist S. Reiss described the structure of the basic desires of a professional athlete. Reiss concluded that they are

${ }^{3}$ Uprawianie sportu pomaga $w$ biznesie [Engaging in sport helps in business], Akademia Sportu i Biznesu [Academy of Sport and Business], Inwestycje.pl, http://inwestycje.pl/biznes/ Uprawianie-sportu-pomaga-w-biznesie;206553;0.html, 2013, (accessed on January 11, 2016). 
concentrated in five features of athletes that help in a business career. They are competiveness, curiosity, low need for acceptance, honor, and physical activity. According to Reiss, these features not only increase efficiency in sports, but also do so at work. (Mrozowski).

Obviously, employer decisions are not solely based on how well someone has done on the field or in the gym. This allows the assumption that most negative stereotypes about athletes and their capabilities and predispositions to work in the professional world are not necessarily true. One might even risk saying that most of the negative stereotypes are misleading and harmful.

In accordance with the Pyramid of Success, John Wooden (an all-time great U.S. basketball coach) maintains that the main level of the pyramid includes qualities such as diligence, friendship, loyalty, the ability to cooperate, and enthusiasm. Further features for the proper development of a business are the sense of belonging to the team, determination, confidence, poise, and excellence in competition at the very top. Wooden emphasized that these entrepreneurial qualities can be developed by practicing professional sports (Musztyfaga and Myśliwiec, 2016).

\section{Objectives and Methodology}

This article aims at identifying the entrepreneurial qualities of athletes in selected sport disciplines. Countless articles and studies point out that athletes are a valuable asset on the rosters of many companies. Athletes have a great set of traits, including what many employers seek-dedication to work. Most studies focus on this subject from the point of view of the employer.

In this study the authors have formulated the hypothesis that:

- Professional athletes have strongly developed entrepreneurial qualities. Quantitative research was carried out in order to look into this matter. The authors conducted a survey using the CAWI method during September and October of 2016. The survey was carried out among respondents who were athletics competitors (the selected individual sport) and basketball players (the selected team sport). Because of the small sample size, in the second step, research was expanded to include two additional disciplinesthe triathlon (the second individual sport) and volleyball (the second team sport) - in the second phase. Invitations to participate in the survey were sent via e-mail to athletes and made available on the official website of the Polish Athletic Association (PZLA) and the Polish Basketball League (PLK) as well as on a dedicated Facebook profile. 
The sample choice was targeted for this research. Respondents were athletes representing different nations, mainly Poland, but also eleven other countries (Argentina, Belgium, Canada, France, Germany, Hungary, Iceland, Russia, Slovakia, Ukraine, and the United States). The authors achieved a satisfactory sample size in their research-115 respondents. For their study the authors used an online version of the measuring instrument. The survey consisted of question-statements with which respondents could agree or disagree. A seven-point numerical scale was used-a Likert Scale (Kaczmarczyk, 2011) in which respondents had to indicate answers using numbers from one to seven where one signified, "I definitely disagree" while seven signified, "I definitely agree." There was also one open-ended question in order to obtain more complete opinions and suggestions from all athletes participating in the questionnaire.

The questionnaire consisted of two parts. The survey began by examining the development of the six selected entrepreneurial qualities of respondents-confidence, determination, courage, creativity, organizational abilities, and leadership. In the second part of the questionnaire, there were questions making it possible for the authors to establish the profile of the respondents.

A holistic approach to the subject also required desk research. For this study the authors used several sources of information available in paper or electronic form. The most recent data were obtained from Internet resources. In addition, some of the information included in the study involved the author's own experiences (both authors are former athletes) as well as observations.

\section{Results and Discussion}

The study involved 115 people. In the respondent profile, the authors asked about the socio-demographic characteristics of the athletes in the selected sporting disciplines. Questions included gender, age, nationality, education, and field of study. The gender structure of the analysis showed that a majority of respondents consists of men (59.1\%) with the remaining $40.9 \%$ of the sample is made up of women.

Most of the surveyed athletes were young people who were not yet thirtysix $(76.5 \%)$. This included the largest group that was aged $18-25(31.3 \%)$. Details of the age structure are shown in Figure No. 1. 
Figure No. 1. Age structure of the respondents

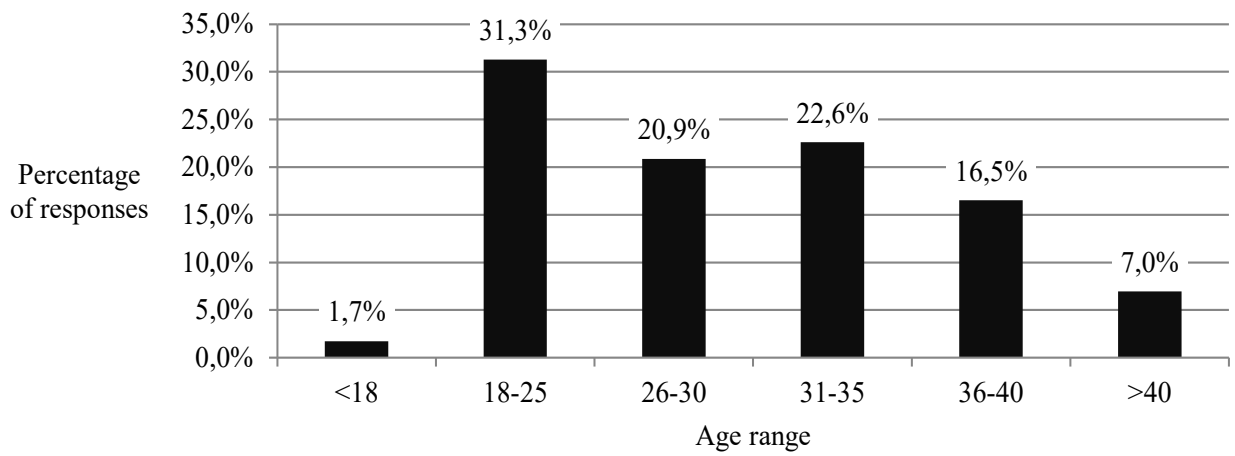

Source: Own study based on the survey.

Respondents from twelve countries and three continents, i.e. Europe, North America and South America, took part in this study. Because the study was prepared by Polish researchers the vast majority of surveyed athletes came from Poland (82.4\%). The next largest group of respondents consisted of representatives of the United States (6.9\%). The remaining nationalities of the respondents are shown in Figure No. 2.

Figure No. 2. The educational structure of the respondents

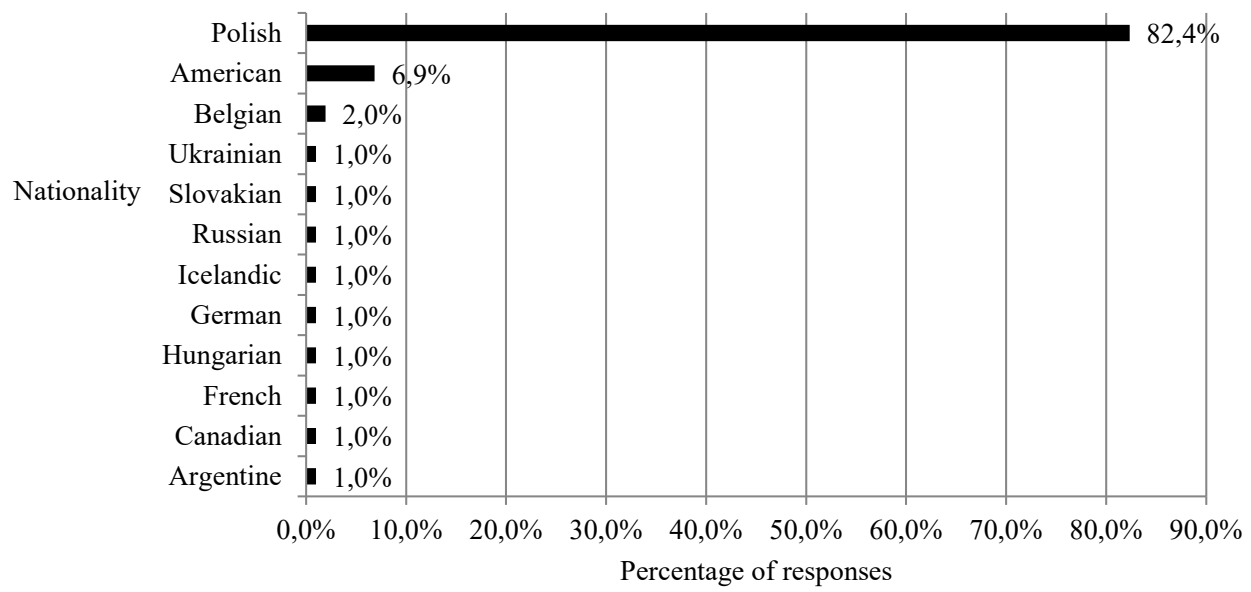

Source: Own study based on the survey.

At the time of the study, most of the respondents (73.0\%) declared a higher education, postgraduate studies, or were currently students. The remainder $(27.0 \%)$ of the respondents had a secondary education and only less than one percent of surveyed athletes had only the lowest level of 
education. The percentage structure of educational level among respondents is shown in Figure No. 3.

Figure No. 3. The education structure of the respondents

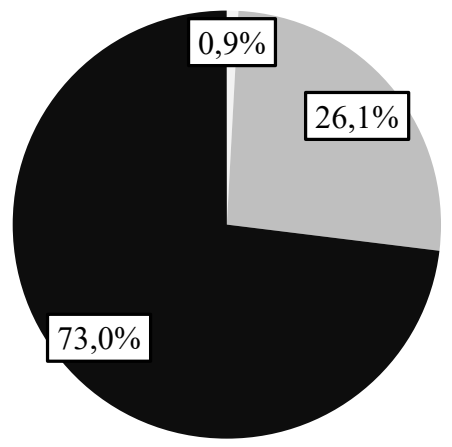

Elementary $\square$ Secondary $\square$ Higher

Source: Own study based on the survey.

Results also show the field of study from which respondents graduated or are actually in at the time of the research. The respondents encompassed more than forty different scientific disciplines. The largest number of respondents indicated that they took a degree in physical education (15.7\%) or physiotherapy (14.7\%). The next largest group (12.7\%) specified fields associated with management and/or marketing. More than 5\% of the respondents indicated a field in social communication, human resources, tourism, and sport management. To sum up, the vast majority of surveyed athletes graduated in scientific disciplines directly associated with sports, where every third respondent studied physical education or physiotherapy.

Figure No. 4. Sports disciplines practiced by the respondents

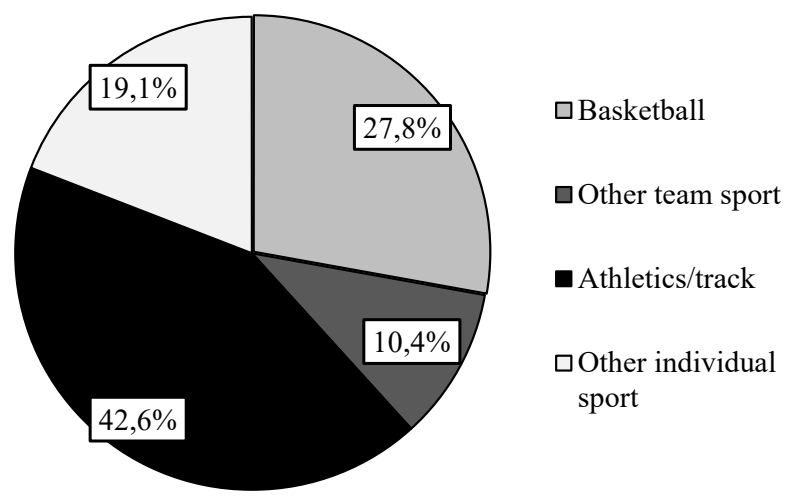

Source: Own study based on the survey. 
The successive part of the questionnaire examined the sport disciplines practiced by the respondents. Results showed that the majority of respondents $(61.7 \%)$ who practiced individual sports $-42.6 \%$ were athletes (runners) while $19.1 \%$ were triathletes. The remaining $38.3 \%$ of the sample practiced team sports-27.8\% were basketball players and $10.4 \%$ were volleyball players. What is more, a total of $81.4 \%$ of all the respondents were still active athletes.

The next part of the questionnaire checked the development among respondents of the six selected entrepreneurial qualities-confidence, determination, courage, creativity, organizational abilities, and leadership. These aspects were examined using question-statements with which the respondents could agree or disagree (using a seven-point numerical scale, where one signified "I definitely disagree" and seven signified "I definitely agree"). Result analysis calculated the average responses for all respondents and separately calculated the average of the surveyed athletes of individual sports and a team sports.

The first set of entrepreneurial qualities examined involved aspects of confidence. In the questionnaire the respondents answered three questions associated with self-assurance (Table No. 2). The average rating of responses on a scale from one to seven was very high-5.8. This means that the surveyed athletes have important entrepreneurial qualities relating to confidence. No significant differences were observed between responses from surveyed athletes of individual and team sports. What was assumed was that people who are aware of their own possibilities and advantages can achieve their goals in business faster as well as overcome any difficulties. What is more, confidence is an important characteristic in negotiations and contacts with business partners, customers, and competitors.

Table No. 2. Average Rating of Statements/Questions Regarding Confidence by Respondent Groups

\begin{tabular}{|c|l|c|c|c|}
\hline \multirow{2}{*}{$\begin{array}{c}\text { SPORTSMAN } \\
\text { QUALITY }\end{array}$} & \multicolumn{1}{c|}{$\begin{array}{c}\text { Research Statements / } \\
\text { Questions }\end{array}$} & \multicolumn{3}{|c|}{$\begin{array}{c}\text { Average Rating by } \\
\text { Respondents (scale from 1 to 7) }\end{array}$} \\
\cline { 3 - 5 } & \multicolumn{1}{|c|}{$\begin{array}{c}\text { All } \\
\text { CONFIDENCE }\end{array}$} & $\begin{array}{c}\text { Individual } \\
\text { sports }\end{array}$ & $\begin{array}{c}\text { Team } \\
\text { sports }\end{array}$ \\
\cline { 2 - 5 } & $\begin{array}{l}\text { Iuring a competition. } \\
\text { I know that I'm an important player } \\
\text { for the team I represent. }\end{array}$ & 5.5 & 5.6 & 5.6 \\
\cline { 2 - 5 } & $\begin{array}{l}\text { I know that thanks to appropriate } \\
\text { commitment I'm able to succeed. }\end{array}$ & 6.3 & 6.4 & 6.3 \\
\hline
\end{tabular}

Source: Own study based on the survey. 
Table No. 3. Average Rating of Statements/Questions about Determination by Respondent Groups

\begin{tabular}{|c|l|c|c|c|}
\hline \multirow{2}{*}{$\begin{array}{c}\text { SPORTSMAN } \\
\text { QUALITY }\end{array}$} & Research Statements / Questions & \multicolumn{3}{|c|}{$\begin{array}{c}\text { Average Rating by } \\
\text { Respondents (from 1 to 7) }\end{array}$} \\
\cline { 3 - 5 } & & All & $\begin{array}{c}\text { Individual } \\
\text { sports }\end{array}$ & $\begin{array}{c}\text { Team } \\
\text { sports }\end{array}$ \\
\hline \multirow{2}{*}{ DETERMINATION } & $\begin{array}{l}\text { I complete each training unit (prac- } \\
\text { tice) according to plan. }\end{array}$ & 5.6 & 5.4 & 5.9 \\
\cline { 2 - 5 } & $\begin{array}{l}\text { I always have a positive attitude } \\
\text { before a competition. }\end{array}$ & 5.7 & 5.6 & 5.7 \\
\cline { 2 - 5 } & $\begin{array}{l}\text { Regardless of the situation I'm in, } \\
\text { I'm ready to work and train. }\end{array}$ & 5.5 & 5.2 & 5.6 \\
\cline { 2 - 5 } & Only victory counts for me. & 4.3 & 3.6 & 5.3 \\
\hline
\end{tabular}

Source: Own study based on the survey.

The next entrepreneurial quality that was checked among respondents was determination. In the questionnaire, the respondents answered four questions involving aspects of determination (Table No. 3). The average rating of responses regarding determination on a scale from one to seven was high-5.28. However, it was lower then in the case of confidence. Additionally, these results make possible an observation of differences between responses from surveyed athletes of individual and team sports. The results show that respondents who practiced team sports had a higher level of determination. As an example, victory in competition is much more important for surveyed basketball and volleyball players as compared with respondents involved in individual sports.

It is worth noting that engagement in training can translate into involvement in daily work and in achieving long-term objectives. These characteristics are important for today's entrepreneurs. Moreover, if on thinks positively about competition, one also thinks positively about one's own business and its future.

Courage was the next entrepreneurial quality that was examined. Respondents were asked to answer three questions (Table No. 4). The average rating of responses regarding courage on a scale from one to seven was high-5.60. Only minor differences between the responses of athletes of individual and team sports were observed in the research. The only difference was that respondents who played team sports (an average rating of 5.1) as compared with the responses of athletes of individual sport (an average rating of 4.8) was that it pointed to them being slightly more curious. 
Table No. 4. Average Rating of Statements/Questions about Courage by Respondent Groups

\begin{tabular}{|c|l|c|c|c|}
\hline \multirow{5}{*}{$\begin{array}{c}\text { SPORTSMAN } \\
\text { QUALITY }\end{array}$} & Research Statements / Questions & \multicolumn{3}{|c|}{$\begin{array}{c}\text { Average Rating by } \\
\text { Respondents (scale from 1 to 7) }\end{array}$} \\
\cline { 3 - 5 } & & All & $\begin{array}{c}\text { Individual } \\
\text { sports }\end{array}$ & $\begin{array}{c}\text { Team } \\
\text { sports }\end{array}$ \\
\hline \multirow{5}{*}{ COURAGE } & $\begin{array}{l}\text { I often take chances during a com- } \\
\text { petition because I'm curious as to if } \\
\text { I can maintain my high pace. }\end{array}$ & 4.8 & 4.6 & 5.1 \\
\cline { 2 - 5 } & $\begin{array}{l}\text { I can admit defeat / I know how to } \\
\text { lose. }\end{array}$ & 5.8 & 5.8 & 5.8 \\
\cline { 2 - 5 } & $\begin{array}{l}\text { I can take responsibility for my final } \\
\text { result (individual sports) or the result } \\
\text { of my team. }\end{array}$ & 6.2 & 6.2 & 6.3 \\
\hline
\end{tabular}

Source: Own study based on the survey.

What is important is that courage is directly related to risk-taking as well as to discovering new solutions. Without courage the entrepreneur cannot take risks and cannot make difficult decisions or cannot make tough choices. On the other hand, curiosity is associated with courage. It is the basic desire for cognitive activity. Curiosity stimulates potential of discovery and engages in a search for new opportunities. It is a desire that helps in getting to know oneself-one's own strengths and weaknesses as well as one's own physical and mental boundaries. Knowledge about oneself helps in doing business. What is more, in the first stage of a sport career, young teams often lose rather than win. Only brave people can overcome defeat. Moreover, every failure should be an incentive for the next workout. The same situation can be transferred into the business environment. Thus, motivation for action in spite of obstacles is essential for good business.

The successive entrepreneurial quality that was checked among respondents was creativity/innovation. Respondents answered two questions involving creative aspects (Table No. 5). The average rating of responses was the highest-5.90. The results show some differences between the responses of athletes of individual and team sports. All surveyed athletes did not like monotony in training. For this reason they probably also would not like boredom in professional life. Differences cropped up in looking for new solutions. Respondents who played team sports (an average rating of 5.8) compared to athletes of individual sports (an average rating of 5.1) had a higher level of seeking. What is important is that in the business 
environment creative thinking allows for quick and flexible analysis of situations within and outside the company.

Table No. 5. Average Rating of Statements/Questions about Creativity/Innovation by Respondent Groups

\begin{tabular}{|c|l|c|c|c|}
\hline \multirow{2}{*}{$\begin{array}{c}\text { SPORTSMAN } \\
\text { QUALITY }\end{array}$} & Research Statements / Questions & \multicolumn{3}{|c|}{$\begin{array}{c}\text { Average Rating by } \\
\text { Respondents } \\
\text { (scale from 1 to 7) }\end{array}$} \\
\cline { 2 - 5 } & All & $\begin{array}{c}\text { Individual } \\
\text { sports }\end{array}$ & $\begin{array}{c}\text { Team } \\
\text { sports }\end{array}$ \\
\hline \multirow{2}{*}{$\begin{array}{l}\text { CREATIVITY/ } \\
\text { INNOVATION }\end{array}$} & $\begin{array}{l}\text { I always look for new solutions during } \\
\text { a competition in order to win against } \\
\text { an opponent/rival. }\end{array}$ & 5.4 & 5.1 & 5.8 \\
\cline { 2 - 5 } & $\begin{array}{l}\text { I like it when practice is diverse and } \\
\text { challenging. }\end{array}$ & 6.4 & 6.3 & 6.5 \\
\hline
\end{tabular}

Source: Own study based on the survey.

Table No. 6. Average Rating of Statements/Questions Regarding Organizational Abilities and Leadership by Respondent Groups

\begin{tabular}{|l|l|c|c|c|}
\hline \multirow{2}{*}{$\begin{array}{c}\text { SPORTSMAN } \\
\text { QUALITY }\end{array}$} & Research Statements / Questions & \multicolumn{3}{|c|}{$\begin{array}{c}\text { Average Rating by } \\
\text { Respondents } \\
\text { (scale from 1 to 7) }\end{array}$} \\
\cline { 2 - 5 } & All & $\begin{array}{c}\text { Individual } \\
\text { sports }\end{array}$ & $\begin{array}{c}\text { Team } \\
\text { sports }\end{array}$ \\
\hline \multirow{2}{*}{$\begin{array}{l}\text { ORGANIZA- } \\
\text { TIONAL ABILI- } \\
\text { TIES AND } \\
\text { LEADERSHIP }\end{array}$} & $\begin{array}{l}\text { I have the predisposition to inspire } \\
\text { others to practice and I can motivate } \\
\text { and persuade them to act. }\end{array}$ & 5.4 & 5.3 & 5.7 \\
\cline { 2 - 5 } & $\begin{array}{l}\text { I know that my team can do much } \\
\text { vidually. }\end{array}$ & 6.0 & 5.8 & 6.3 \\
\cline { 2 - 6 } & $\begin{array}{l}\text { I respect the opinion and comments } \\
\text { of my coach as well as of other mem- } \\
\text { bers of the team. }\end{array}$ & 6.3 & 6.3 & 6.4 \\
\hline
\end{tabular}

Source: Own study based on the survey.

The last, but certainly not least important entrepreneurial qualities that were checked among respondents were organizational abilities and leadership. Respondents were asked to answer for three questions (Table No. 6). The average rating of their responses was the highest -5.90 . These results 
allow the observation of some differences between the responses from the athletes of individual and team sports. The results show that respondents who play team sports are more confident that their team can do much more together than any of them individually. Additionally, respondents who play in team sports are more convinced that they have predispositions for motivating others to practice sports. It is worth noting that organizational ability and leadership make possible working in a team. The study shows that a greater predisposition to work in a group is a quality of athletes involved in team sports.

Figure No. 5. List of the entrepreneurial qualities developed during a sporting career in the case of the respondents by percentage of indications

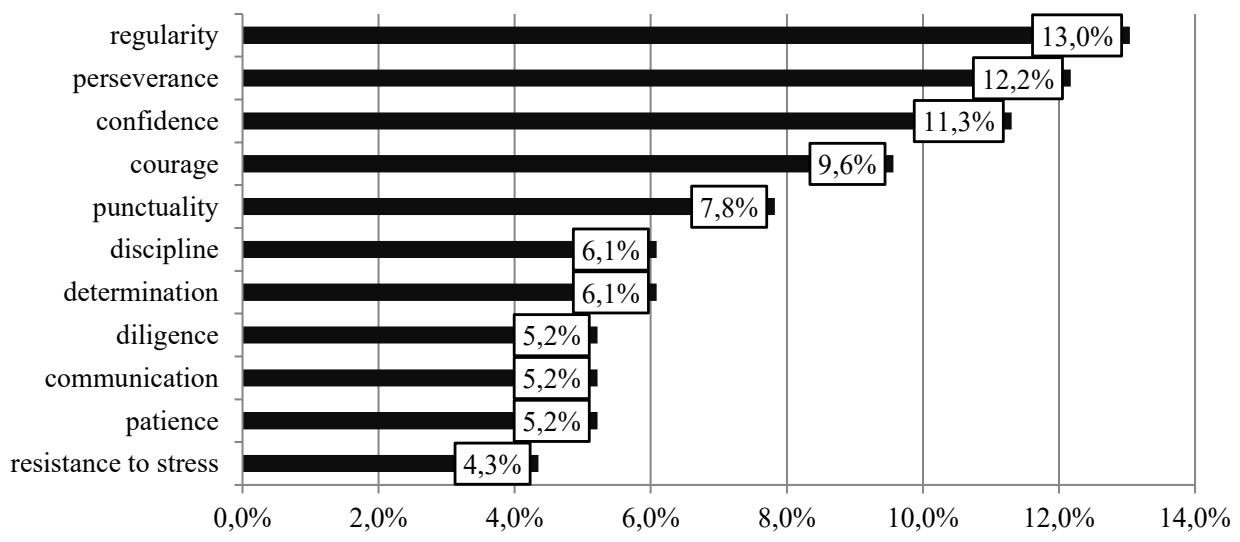

Source: Own study based on the survey.

At the end of the questionnaire respondents were asked to indicate three additional entrepreneurial qualities not mentioned earlier that they developed during their sporting careers. This was an open question and the most frequent indications are presented in Figure No. 5. Some respondents duplicated the qualities listed in the previous questions. Nevertheless, surveyed athletes indicated more than forty additional entrepreneurial qualities. The most respondents (more than every tenth person) cited regularity (13.0\%), perseverance $(12.2 \%)$, and confidence (11.3\%). Subsequently, the respondents pointed to courage, punctuality, and discipline. Furthermore, respondents also indicated diligence, communication, and patience. All of these qualities of sportsmen can be transferred to their professional life. There is no denying that professional sports develop many entrepreneurial qualities. 


\section{Conclusion}

All entrepreneurial qualities in athletes mentioned in this study were highly rated. The average for all characteristics was 5.70 (on a scale from one to seven where "one" signified "I definitely disagree" while "seven" signified "I definitely agree" with statement about a particular entrepreneurial quality). This means that the stated hypothesis of this study has been confirmed: Professional athletes have strongly developed entrepreneurial qualities.

Individual sport athletes have a higher level of confidence as well as a greater awareness of their own value as compared to team sport athletes. Hence, they are more predisposed to start their own businesses. Team sport athletes have the greater ability to cooperate with others (higher level of determination, creativity, and organizational abilities) than individual sport athletes.

This information should be important for companies that are focused on team projects. This study confirmed the assumption that the success of an athlete translates into success for the entrepreneur.

\section{References}

Bednarczyk, M. and Nessel, K. (2016). Przedsiębiorczość w sporcie. Zasady i praktyka [Entrepreneurship in sport: Principles and practice]. Warsaw: CeDeWu.pl Publishers.

Danielewicz, D. (2014). Wewnętrzne i zewnętrzne determinanty kształtujące postawę przedsiębiorczą [The internal and external determinants shaping entrepreneurial attitudes]. In: A. Postuła, B. Glinka, and J. Pasieczny (Eds), Oblicza przedsiębiorczości [The faces of entrepreneurship]. Warsaw: Faculty of Management University of Warsaw Scientific Publishers.

Drucker, P.F. (1992). Innowacja i przedsiębiorczość. Praktyka i zasady [Innovation and entrepreneurship: Practice]. Warsaw: PWE Polish Economic Publishers.

Glinka, B. (2015). Paweł Falicki - Trzy dekady przedsiębiorczości. Determinanty rozwoju przedsiębiorczości [Paweł Falicki - Three decades of entrepreneurship: The determinants of development of entrepreneurship]. In A. Brzozowska, I. Postuła, and P. Kłobukowski (Eds.), Przedsiębiorczość - studia przypadków [Entrepreneurship: Case studies]. Warsaw: Faculty of Management University of Warsaw Scientific Publishers.

Greathouse, J. (2015). Entrepreneurs Are Born, Not Created. Forbes, February. Retrieved from: http://www.forbes.com/sites/johngreathouse/2015/02/12/entrepreneurs-are-born-notcreated/\#ba22ef43003d.

Howes, L. (2015). The School of Greatness: A Real-World Guide to Living Bigger, Loving Deeper, and Leaving a Legacy. Audible Studios on Brilliance Audio.

Kaczmarczyk, S. (2011). Badania marketingowe. Podstawy metodyczne [Marketing research: A methodological basis]. Warsaw: PWE Polish Economic Publishers.

Kostera, M. and Śliwa, M. (2012). Zarządzanie w XXI wieku. Jakość, twórczość, kultura [Management in the 21st century: Quality, creativity, culture]. Warsaw: Wolters Kluwer Business Publishing House. 
Mrozowski, M. (2015). 5 cech sportowców, które pomagają w karierze [Five qualities of sportsmen that help in a career]. Forbes.pl. Retrieved from: http://psychologiasprzedazy. biz/5-cech-sportowcow-ktore-pomagaja-w-karierze/ (11. 01.2016).

Mruk, H. (2006). Sukces sportowca a sukces przedsiębiorcy [The success of a sportman and the success of an entrepreneur]. In: H. Mruk, K. Kropielnicki (eds.), Marketing dla sportu [Marketing for sport] (pp. 35-42). A publication summing up the IV Days of Sporting Marketing. Poznań: Sport \& Business Foundation.

Musztyfaga, A. and Myśliwiec, K. (2016). Kompetencje przedsiębiorcze [Entrepreneurial competencies]. In: M. Bendarczyk and K. Nessel (Eds.), Przedsiębiorczość w sporcie [Entrepreneurship in sport] (pp. 31-46). Warsaw: CeDeWu.pl Publishers.

Piecuch, T. (2013). Przedsiębiorczość. Podstawy teoretyczne [Entrepreneurship: Theoretical basis]. Warsaw: C.H. Beck Publishers.

Sudoł, S. (2006). Przedsiębiorstwo. Podstawy nauki o przedsiębiorstwie. Zarzadzanie przedsiębiorstwem [Entrepreneurship: Scientific basis of companies and company management]. Warsaw: PWE Polish Economic Publishers.

Vozza, S. (2014). Why Your Next Employee Should Be a Former Student Athlete, October 4. Retrieved from: https://www.fastcompany.com/3028829/why-your-next-employee-shouldbe-a-former-student-athlete.

Weber, E.U., Blais A.R. and Betz, N.E. (2002). A Domain-Specific Risk-Attitude Scale: Measuring Risk Perceptions and Risk Behaviors. Journal of Behavioral Decision Making, 15, 263-290.

Wójcik, G.P. (2014). Przedsiębiorczość, kreatywność, zdolność do uczenia się źródłem wzrostu konkurencyjności przedsiębiorstw [Entrepreneurship, creativity, and the ability to learn as a source of improvement in company competitiveness]. In: A. Postuła, B Glinka, and J. Pasieczny (Eds.), Oblicza przedsiębiorczości [The faces of entrepreneurship]. Warsaw: Faculty of Management University of Warsaw Scientific Publishers. 



\section{Część II}

\section{O systemach}





\section{Luigi Lai*}

\section{EU Insolvency Regulations: New Tendencies Fostering Entrepreneurship in Europe}

Insolvency and entrepreneurship are different sides of the same coin. Any entrepreneurial activity has to face the prospect of insolvency. Insolvency is a possibility and this is why any entrepreneur needs to have some notions of insolvency law in order to safely direct the firm when unexpected market turbulence may lead it close to bankruptcy.

In the United States many successful companies had their origin in a previous failure. Today, insolvency does not merely consist of aggressive procedures aimed at debtor divestment. On the contrary, the field of insolvency is now much more than that. The European Union is striving to create a friendly business environment and for this reason has implemented a new set of laws allowing for what may be called a "second chance." This article conducts a legal analysis of aspects of EU insolvency regulations that may lead to the formation of a new generation of entrepreneurs who are conscious of the new possibilities given by the concrete effects of the "second chance theory." After a brief description of the concepts of universality and territoriality, the article primarily describes the main characteristics of EU regulations as contained in insolvency law, commonly known as "EIR." Secondly, the article shows the main changes made to the EIR and its new Recast.

The paper methodology is based on analysis of the EIR's main characteristics as well as some interesting decisions adjudicated by the European Court of Justice in the field of insolvency. The EIR and its Recast are an important step forward in achieving a more effective solution for cross border insolvency proceedings. Nonetheless, EU member states are reluctant to devolve their competences on insolvency law to the European Union. It is for this reason that the EU legislator has been so timid in harmonization efforts. In the absence of true harmonization, stronger cooperation in the insolvency field should be fostered among courts in the European Union.

Often entrepreneurs, due to a lack of knowledge in the insolvency field, are not aware that insolvency is not just bankruptcy. For this reason they confine themselves to a narrow perimeter of action. Thus, they may lose the possibility of making complete and thoughtful decisions. The article hopes to contribute to disseminating among entrepreneurs a set of legal notions that may lead to better management and better prevision of cross-border insolvency situations before they happen (ex ante), not after (ex post).

* Luigi Lai, Ph.D. Candidate - National Information Processing Institute, www.opi.org.pl; e-mail: luigilai111@gmail.com. 
The successive article on this topic will analyze several interesting aspects of the national regulations of certain EU states.

Keywords: second chance theory, European Union, International Law.

\section{Nowe tendencje w regulacjach UE dotyczących niewypłacalności wspierających przedsiębiorczość w Europie}

Przy dowolnej działalności przedsiębiorczej należy uwzględnić możliwość niewypłacalności. Skoro niewypłacalność zawsze jest możliwa, każdy przedsiębiorca - aby bezpiecznie kierować firmą w sytuacji nieoczekiwanych zaburzeń na rynku, które mogą doprowadzić firmę do bankructwa - musi mieć świadomość prawa dotyczącego niewypłacalności. W Stanach Zjednoczonych wiele odnoszących sukcesy firm narodziło się w wyniku wcześniejszej klęski. Dzisiaj niewypłacalność nie składa się jedynie z agresywnych procedur dezinwestycyjnych dłużnika, lecz jest domeną dużo szerszą. Unia Europejska stara się stworzyć przyjazne środowisko biznesowe i właśnie dlatego wprowadziła przepisy pozwalające na coś, co można nazwać "drugą szansą".

Artykuł analizuje aspekty regulacji UE dot. niewypłacalności z punktu widzenia tworzenia nowego pokolenia przedsiębiorców, mających świadomość możliwości, jakie dają konkretne skutki „teorii drugiej szansy”. Po krótkim opisie idei uniwersalności oraz terytorialności, artykuł opisuje podstawowe elementy regulacji UE dot. niewypłacalności (EIR), a następnie pokazuje główne zmiany spowodowane przez EIR w ich najnowszej wersji. Metodologia artykułu opiera się na analizie głównych elementów charakterystycznych dla EIR, a także kilku interesujących orzeczeń Trybunału Sprawiedliwości Unii Europejskiej w dziedzinie niewypłacalności. EIR w najnowszej wersji to ważny krok na drodze do bardziej skutecznego rozwiązania procedur transgranicznych w sprawach o niewypłacalność. Niemniej, państwa członkowskie Unii Europejskiej niechętnie oddają swoje kompetencje w dziedzinie prawa dot. niewypłacalności. Właśnie z tego powodu prawodawca UE jest zbyt ostrożny w próbach harmonizacji i dlatego należy dążyć do lepszej współpracy pomiędzy sądami w Unii Europejskiej w dziedzinie niewypłacalności.

Brak wiedzy jest często przyczyną nieświadomości przedsiębiorców, że niewypłacalność to nie tylko bankructwo. Dlatego też ograniczają się oni do wąskiego zakresu działań i tym samym mogą stracić możliwość dokonania w pełni świadomych decyzji. Artykuł ma na celu rozpowszechnienie koncepcji prawnych, które mogą prowadzić do lepszego zarządzania oraz lepszego przewidywania sytuacji niewypłacalności transgranicznych ex ante niż ex post. Kolejny artykuł dotyczący tej sprawy przeprowadzi analizę kilku interesujących aspektów regulacji niektórych państw członkowskich UE.

Słowa kluczowe: teoria drugiej szansy, Unia Europejska, prawo międzynarodowe. Jel: K2, K33

In a global economic situation characterized by general budgetary contraction, national work forces tenuously aspire to get public work positions. For this reason entrepreneurship is the backbone of modern societies and for this same reason it has to be protected (Armour, 2008). A country has to foster entrepreneurship and can do so by constructing a pro-business environment that will provide fertile soil where entrepreneurship can germinate. 
Entrepreneurs are pivotal for the positive transformation of local communities. They recognize opportunity, mobilize resources, and create value. In other words, they are a key element for progress. Entrepreneurs benefit from different factors. One of the most important elements for the creation of fertile entrepreneurial soil is to have a legal system where insolvency encompasses a vast range of possibilities that allow company restructuring. Bankruptcy is just one of the many possibilities provided by a legal system. If an insolvent entrepreneur is excessively punished, disaffected, he or she may leave aside potentially high-return opportunities (Seung, 2007).

Economic turmoil started in 2008 and increased the pace at which the European Union looked for a new definition for entrepreneurship. In 2012 the European Commission published an important communication entitled, "Reigniting the Entrepreneurial Spirit in Europe." This publication guarantees the centrality of entrepreneurship in the EU environment and affirms the need for providing honest bankrupts with a second chance. The communication states: "Business failure, like business creation, is part of a dynamic, healthy market. Evidence shows that by far the majority (96\%) of bankruptcies are due to a string of late payments or other objective problems-they are, in other words 'honest failures,' without any fraud by the entrepreneur. Entrepreneurs are nevertheless treated by many bankruptcy laws as if they were fraudulent, having to go through complex procedures before they can be discharged." Often, the companies rising out of the ashes of a previous insolvency are stronger and healthier than other companies. Moreover, it has been analyzed that countries with a less repressive insolvency system are much more likely to have an entrepreneurial blossoming. Insolvency has to become an opportunity to learn from mistakes, an opportunity to encourage the new generations to be brave as well as for the poorest to take a chance and change. In the words of the commission: "If the first idea does not fly, the new entrepreneurs will not be forever barred from trying to 'take off' again. Thus insolvency laws must provide for swift, efficient ways of lodging and recovering claims for creditor enterprises, while faster and more affordable procedures for winding up businesses and for discharge from bankruptcy should be put in place."

Analysis shows that entrepreneur-friendly bankruptcy laws are significantly correlated with the level of entrepreneurship development as measured by the rate of new firm entry (Lee, Seung-Hyun, and Yamakawa. 2011). EU legislation in the insolvency field is far from perfect (Liddy-Murphy, 2015). The European Union has a long way to go to reach a truly second chance approach, but the firsts steps have been carried out in the right direction.

Insolvency and entrepreneurship are different sides of the same coin. Any entrepreneurial activity has to face the possibility of insolvency. Insolvency 
is a possibility and for this reason every entrepreneur needs to have some notions of insolvency law in order to safely lead the company when unexpected market turbulences may push it to the verge of bankruptcy. In the United States many successful companies had their origin out of a previous failure (Gunderson, 2005). Currently, insolvency does not merely consist in aggressive procedures aimed at debtor divestment. On the contrary, the field of insolvency now encompasses much more than that.

Every entrepreneur needs to master and understand the principles and new tendencies of insolvency law so as to be prepared to face unexpected crises. This concept may be condensed in the famous Latin phrase: "Si vis pacem, para bellum," which can be understood as meaning that entrepreneurs need to prepare themselves so as to be ready when the crisis arrives.

This article focuses on showing the reader that the new tendencies in EU insolvency law are heading to transform it into a tool capable of fostering entrepreneurial activities across the European Union. We are now witnessing vast changes in the insolvency contest (Lai, 2012). It is impossible not to notice that an insolvency proceeding may not just focus on creditors satisfaction. In other words, an insolvency proceeding should not be considered as just a proceeding aimed at company asset liquidation. This kind of proceeding, when circumstances make it possible, must also aim at the company's restructuring in order to protect its intrinsic value. Periodic economic downturns may often result in creditors chasing after the assets of their distressed debtors. This aggressive function of insolvency shall not be sublimated. However, it may occur that under certain conditions a company's survival is also crucial. In 2000 the European Union issued the first regulation on insolvency law aimed at coordinating cross-border insolvency cases. Regulation No. 1360/2000, informally known as the European Insolvency Regulation (EIR), is the result of a compromise among the different visions of the individual states. For this reason, the EIR's main scope is coordinating different proceedings, not harmonizing different state laws. It is, however, unarguable that the EIR has helped to promote a new concept of insolvency law among the member states-less aggressive and more devoted, when possible, to restructuring companies in distress. More specifically, the EIR Recast issued in 2016 corrects some of the defects that arose from the application of the first version of the EIR. At the same time it shows a stronger intent for limiting insolvency's aggressive function. This article emphasizes this characteristic of the EIR and describes the novelties introduced by the Recast. The two versions of the Regulation were the object of analysis and this article underlines the main features of the first version and the main changes of the Recast. This paper is mainly based on this legislative work and takes into consideration 
several important decisions of the European Court of Justice (CJEU) in insolvency matters. Analysis of the new ancillary proceedings have been left out purposefully (ancillary proceedings in the new Recast will be the object of the next article). The new approach to insolvency law, as previously mentioned, is clearly caused by the common law approach of giving a second chance. Such an approach was previously developed in the United States and has finally arrived in "Continental Europe" via the United Kingdom. Just a couple of months have passed since what is known as the "Brexit Referendum." Due to the important role that has been played by UK jurisprudence in the insolvency law in Europe (Jakson, 1986), a next step will be to analyze the effects caused by such an event on the question of insolvency in the European Union.

\section{Universality and Territoriality}

Periodic economic downturns often result in creditors chasing after the assets of their financially distressed debtors, often located all over the world. Over the past two decades this quest for satisfaction has led to creditors seeking the assistance of foreign courts in order to recover debts owed them. However, the disparate nature of domestic insolvency systems in Europe and the lack of efficient and effective international conventions lead to unsatisfactory results.

Sometimes an insolvency proceeding may cross a state's border. Sometimes an insolvency proceeding's relevance may reach such an international extent so as to suddenly become a modern-day Hydra. In Greek mythology the Hydra was a monster resembling a serpent that possessed many heads and was so powerful that it could only be defeated by Hercules. When an insolvency proceeding has an international extent, it usually produces a plurality of insolvency proceedings. Trying to coordinate all of them may sometimes resemble the famous second labor of Hercules. Such a problematic approach may stem from the confrontation of the two main insolvency theories - the universalistic theory and the territorial theory (Daniele, 2004).

The universalistic theory affirms that there is only one proceeding and only one massa activa and massa passiva (McCormack, 2014). This theory tries to concentrate all the known disputes under one single authority independently if the bankrupt assets are spread across Europe. In a sense, all creditors will have to make a legal claim before the same authority. The universalistic theory believes in a form of equality among all creditors. 
A relevant question mark is whether the universalistic approach truly guarantees equal treatment for all the creditors or if, a contrario, it promotes the creditors from the state where the claim has been filled.

In its stead, the territorial theory starts with the belief that only a national proceeding may truly guarantee equal treatment among creditors. For this reason, under this theory, a plurality of insolvency proceedings is possibleeach independent of the other. A negative effect of such a theory is the different treatment of creditors living in states where the bankrupt company has a smaller subsidiary. Often, such subsidiaries are undercapitalized and for this reason they represent an obstacle to the true equal treatment of creditors.

\section{Regulation No. 1346/2000: First Version}

The entry into force of Regulation No. 1346/2000 on May 31, 2002 brought an end to the prolonged vacuum marked by the absence of any coordinated international regulation of insolvency proceedings. Rather than attempting to harmonize substantive laws or purporting to be a first step to an all-encompassing pan-European insolvency regime, the Regulation aimed instead at improving the efficiency and effectiveness of insolvency proceedings characterized by cross-border dimensions. It removed the formalities that had previously been associated with recognition and enforcement of other EU court decisions (Wessels, 2009).

Its goal was to establish common rules on cross-border insolvency proceedings based on principles of mutual recognition and coordination. It sought to achieve this goal by harmonizing the rules regarding jurisdiction, striving for creditor equality, introducing uniform rules of conflict between laws, and disincentivising companies from seeking forum shopping. States have been unwilling to accept any competency handover to the European Union. It has to be remembered that there was a time when competencies were considered an aspect of direct states sovereignty by state governments that could not be delegated. For this reason the issuing of Regulation No. 1346/2000 took almost forty years (Lai, 2011).

The EIR established two different types of proceedings. The main proceeding and a secondary one, also termed ancillary. The main proceeding was the proceeding opened in the state where the insolvent company had its "center of main interests" (COMI). The definition of what the COMI really was and whether it coincided with the company's registered offices has been a sore point in the application of the EIR. Due to the fact that no 
definition of the COMI was to be found in Regulation wording, courts in the different states were gravely divided on an interpretation of the COMI during the first ten years of Regulation application. A definition of the COMI was presented in Regulation Recital No. 13, which said, "The 'centre of main interests' should correspond to the place where the debtor conducts the administration of his interests on a regular basis and is therefore ascertainable by third parties." This description of the COMI was in the recital section, which preceded the Regulation, but it was not in the text of the EIR. It seems that state experts could not find a common definition regarding the COMI, so they arrived at a compromise agreement to apply the COMI description found in the recital section. The general description for "center of main interest" was not sufficient to encompass all types of debtors-e.g., natural persons as private individuals, natural persons as professionals, small companies, and large groups of companies with "management and control" locations other than the actuals sites of operations (Paulus, 2006).

Those few lines produced over one thousands pages of various interpretations that forced the European Court of Justice into a role very similar, to some extent, to that of the Supreme Court in the United States. With its interpretative action, the CJEU went beyond its usual limits and created an iure cogente, as in the case of the United States Supreme Court. Moreover, the CJEU changed its opinion on the definition of the COMI over time. In the Eurofood case (C341-04, also known as the Parmalat case), which was the first major case relating to the application of the EIR, the COMI was indicated by the CJEU to be in Ireland. This was in spite of the fact that Eurofood was a very small company that was a part of the Parmalat Group, an Italian company based in Parma. Eurofood was an instrumental company created by Parmalat for the exclusive purpose of signing several financing contracts. The management and control of the company was in Parma, not in Dublin. Nevertheless, the European Court of Justice said that the EIR was not applicable to groups of companies and for this reason Eurofood had to be considered as an independent company, not as part of a holding company. The Eurofood decision seemed to represent a secure bastion-a decision of such importance that it could deeply influence law courts all over the European Union. The situation seemed to be very clear after the Eurofood case ruling. The COMI had to be where the registered offices were, without any consideration of any possible links between the insolvent company and other companies (i.e. groups of companies). The CJEU was trying to narrow the scope of the EIR article on the COMI (Article 3, Paragraph 1 of the Regulation) by focusing on the more objective factors discernible by the parties, especially the company's creditors. 
The CJEU could rely on Recital 4 of the EIR, which explicitly expressed the avoidance of forum shopping as a goal. In addition to this, Recital 13 of the EIR established that the COMI should be in the place where the debtor conducts the administration of its interests on a regular basis and is therefore ascertainable by third parties. The CJEU was trying to protect the legitimate expectations of third parties. The COMI identification, in the opinion of the European Court of Justice, had to depend on external elements that were easily verifiable, so as not to oblige third parties to carry out an analysis regarding the geographical location from where the company was directed. The CJEU truly and deeply tried to settle this long-lasting question.

In opposition to what might have been expected, in the attempt to maintain their jurisdiction on cases, local courts in Europe (Ringe, 2008) continued to interpret the COMI in a very flexible way. This was famously known as the Anglo-Saxon approach. As mentioned above, the first version of the EIR did not take into consideration the insolvency of groups of companies. UK courts, due to their common law traditions, interpreted the Eurofood decision (C-341-04) in a way so as to concentrate all the different proceedings in the court of the state where the group's parent company was located. ${ }^{2}$ UK judges interpreted the part of the Eurofood decision where it was expressed that in order to set the COMI location, easily verifiable external elements have to be used so as not to oblige third parties to carry out an analysis on the geographical place from which the company was directed, in a completely different way. The English judges affirmed that in the case of groups of companies it was clear that third parties referred to the head office of the parent company of the group and that controlled companies could not considered as being independent. ${ }^{3}$

Similar court behavior can be found in France with respect to the Eurotunnel case. Eurotunnel is the company that owns the Euro Tunnel, which is built under the English Channel and connects France and the England. The company had its registered offices in England, but its main office was in France. Eurotunnel had a plurality of companies scattered throughout several EU states. The commercial court in Paris declared its jurisdiction in opening a main proceeding in France under the EIR. The court based its decision, as in the English case, on the fact that the controlled company was basically managed from Paris and that third parties knew this. The CJEU itself in its Interedil (C396/06) and Rastelli (C191/10) rulings moved, stepby-step, to a more flexible interpretation. In the opinion of this author, the

2 The parent company was very often based in the UK.

3 Here, the common law approach of the UK courts is visible, always striving to find the most practical answer to a concrete question. 
CJEU, recognized the evidence that insolvency of groups of companies was becoming an everyday reality and it was not possible to maintain an overly strict interpretation. ${ }^{4}$ In spite of these judicial attempts at reducing forum shopping, forum shopping remained a frequent phenomenon in European restructuring practice (McCormack, 2014). Academia started an interesting debate on the question of whether every change of location of the head office should be condemned and under what conditions. The EU legislator had to create a set of norms that could act as a disincentive for attempts to move the COMI for forum shopping purposes.

The second part of this paper will show that the new version of the EIR significantly reduces legal uncertainty arising from the application of the COMI concept. The EU legislator implemented a set of rules so that a company's registered office was the single decisive criterion and so to ensure that the main insolvency proceedings are always tied to a determined jurisdiction. The EU legislator cannot deny that forum shopping exists, but it has tried to limit it as much as possible (Omar, 2013).

Another interesting aspect of the EIR was the ancillary, or secondary, proceeding. The ancillary proceeding is a kind of proceeding that can be opened in order to create better conditions for creditors, when the main procedure presents some characteristics that do not facilitate full creditor protection. A secondary proceeding can be opened in a state other than the state of the main proceeding only in presence of a dependence (a dependence is not just a belonging as this would not be enough for opening a secondary proceeding). A dependence is an organization of men and goods allowing production. Such a secondary proceeding had to be limited to the state in which the dependence is located. This limitation carries significant importance. In fact, in some states an insolvency proceeding is a universal attempt. Because of this the secondary proceeding puts some limits on the universalistic principle. The authority of the main proceeding had no jurisdiction over the ancillary proceeding and this fact is an insurmountable bastion of the universalistic theory. Another indispensable element for a secondary proceeding to start was to have a previously opened main proceeding. However, a more interesting characteristic was that the basis on which the secondary proceeding could be opened relied on the legal system of the main proceeding. This was a quite peculiar characteristic because when a secondary proceeding was opened on the basis of foreign rules, if under the law of the state of the main proceeding it was possible to open an insolvency proceeding it would be possible to open a secondary proceeding even if the legal system of the state where it should be opened

4 The CJEU was thus filling a normative vacuum. 
did not consider such a possibility. So, for example, if in state alfa (state of the main proceeding) an agricultural entrepreneur (i.e. a farmer) could file for bankruptcy, a secondary proceeding could also be opened if the legal system of state beta did not contemplate such a possibility. A limit to this was represented by the public order clause. In this theoretical case, if a bankruptcy sentence was against the public order clause it could not be implemented in the "receiving" state (Ringe, 2008).

The function of the secondary proceeding was to create a balance to the universalistic power of the main proceeding. The European legislator tried to limit the power of the main proceeding and protect the local creditors. ${ }^{5}$ An excess of complexity of the bankrupt assets may lead the insolvency office holder ${ }^{6}$ to ask for the opening ancillary proceedings. Also, significant legislative differences may lead to new ancillary proceedings. The EU legislator was very pragmatic during the drafting of Regulation No. 1346/2000 and a secondary proceeding could only be opened in presence of a relevant organization of men, goods, or services. In this sense, having an office, a simple real asset, or a mobile asset (e.g., an airplane), in a third-party state is not enough to open an ancillary proceeding. The hierarchy between the main and the ancillary proceeding was not always clear.

Article 29 of the Regulation affirms that every legitimate subject can ask for the opening ${ }^{7}$ of an ancillary proceeding. This opening de facto limited the main proceeding. The law of the state where the secondary proceeding was opened, not the law of the state of the main proceeding, is applied to the secondary proceeding. This is an impressive tool intended to stop the power of the main proceeding, where this tool does not work the other way around. The insolvency office holder (IOH) of the main proceeding cannot avoid or block the opening of a secondary proceeding. For these reasons, it is appropriate to say that the hierarchy has some exceptions. The main proceeding is balanced by the possibility of opening ancillary proceedings. Sometimes, having to cope with different legal systems may create problems and inefficiencies for the IHO, so it may happen that opening several ancillary proceeding may lead to better management (Omar, 2013).

An interesting ancillary proceeding can be seen the Daysitek case. Daysitek was a French holding company with its parent company located in London. However, the parent company was just an "empty box." The financial and administrative core of the company was located in France. The main

\footnotetext{
${ }^{5}$ In this case, the intending creditors.

${ }^{6}$ We are talking about the Insolvency Office Holder of the main proceeding.

7 Only when objective and subjective requirements are met.
} 
proceeding had already been opened in London making it impossible to open a true main proceeding in France. Nevertheless, it was possible to open an ancillary proceeding. ${ }^{8}$ Similar cases include the Rover case between France and England and the Illochroma case in Italy, where the main proceeding was opened in France, but it was actually an Italian proceeding. ${ }^{9}$ What should be noticed in the Illochroma case ${ }^{10}$ is that the French $\mathrm{IOH}$ opposed the opening of an ancillary proceeding. ${ }^{11}$ These examples make it possible to understand how the secondary proceeding might be considered a tool allowing the correction of possible mistakes or a way to avoid forum shopping. ${ }^{12}$ It can happen that, taking into account economic assets, the relevant proceeding is the ancillary one and this could modify the practical hierarchy between the proceedings (Ringe, 2008).

Setting a priori hierarchical rules may lead to difficult practical situations whose resolution is not simple. For this reason the EU legislator, in the Article 31, established the obligation of reciprocal cooperation among the Insolvency Office Holders. This cooperation is not subject to the hierarchical order, it simply means that under certain conditions the two proceedings are equal. However, what should be noticed is that:

- The insolvency office holder of the main proceeding has the right to ask for a three-month suspension of the proceeding.

- The secondary proceeding can consist of only the liquidation of assets. No recovery is possible under the secondary proceeding.

- In the hypothetical case where a secondary proceeding produced an active residual, that active residual has to be passed over to the main proceeding.

As an example on how the Regulation was not completely clear in explaining if there is a hierarchy and how this hierarchy should be interpreted, it is important to analyze Article 32 of the first version of the Regulation (Wessels, 2009). Article 32 stated that a creditor had the right to lodge a claim in any of the proceedings in so far as that lodging is actually

${ }^{8}$ Even if it was an ancillary proceeding formally, de facto, the French proceeding was treated as the main proceeding in spite of the fact that it was limited to French territory.

9 Even if it was the proceeding with the most relevant assets, it was a secondary proceeding.

10 The reader may find the Illochroma decision by looking into the general database of the Italian Ministry of Justice: App. Torino, 10 marzo 2009.

11 Often, Insolvency Office Holders are reluctant to permit the opening of ancillary proceedings. Although Regulation No. 1346/2000 provides tools for better coordination, there is still some resistance.

12 Forum shopping is the informal name given to a practice adopted by some litigants where they have their legal case heard in the court thought most likely to provide a favorable judgment 
useful and is not used as a dilatory tool. An interesting aspect of the integration between proceedings is the credit insinuation. In some states there is a classification of credits that makes some privileged. This classification may look like a pyramid, where position on the pyramid means that some credit will be satisfied before others. A real estate mortgage owned by a bank is without any doubt a privileged credit. On the other hand, an unclassified credit will find itself at the bottom of the pyramid.

Such classification differs from state to state. A credit privileged in one state could be more or less privileged in another state. Regulation No. $1346 / 2000$ does not mention any tool for avoiding superposition or other problematic situations that might create a procedural impasse.

\section{Main Characteristics of the Recast}

As shown above, many points of Regulation No. 1346/2000 were, and still are, a source of problematic issues. The EU legislator has tried to reduce interpretative doubts by issuing the Recast of the EIR.

The Recast has been extended to go beyond liquidation proceedings already covered by the previous EC Regulation No. 1346/2000. The new rules also cover proceedings that provide for the restructuring of a debtor at a stage where there is only a pre-insolvency state- "hybrid proceedings. ${ }^{13 \text { " }}$ The Recast does not modify the fundamental framework of cross-border insolvency as adopted by the EIR. However, new discipline introduced a number of significant changes (Eidenmuller, 2006).

The most important modifications to the EIR Recast relating to the COMI and groups of companies are as follows: The concept of the COMI has been defined more precisely in the body of the EIR (not left in the recital as had been the case). The COMI has been defined as the "place where the debtor conducts the administration of its interests on a regular basis and which is ascertainable by third parties." Hence, the Recast confirms the principle elaborated over time by the CJEU establishing a presumption that the COMI is at the company's registered offices. Nevertheless, the European legislator included an exception to the general rule. It is not possible to rely completely upon the COMI presumption regarding registered offices if an overall assessment of all relevant factors shows that "the company's actual centre of management and supervision" is located in another state in a manner that is ascertainable by third parties. In such a case, the COMI

13 Hybrid proceedings will be examined in a future article. 
will be not at the location of the registered offices. The Recast has found a balance between the need to prevent abusive forum shopping and to preserve freedom of movement (McCormack, 2012).

When a company COMI is shifted in the preceding three months, the presumption that the COMI is at the registered offices does not apply. This modification is very relevant. The EU legislator, after fourteen year of application of the EIR, recognized that the COMI presumption needed a limitation. The EU legislator has been sensible to what the practical experience arising from state courts of justice around the EU has shown. This is a reference to cases such as Susanne Staubitz-Schreiber (Case C-1/04), Eurofood (C-341/04), Deko Marty Belgium (C-339/07), MG Probud (Case C-444/07) Interedil (C-396/09), Rastelli Davide (C-191/10), Bank Handlowy (C-116/11), and Illochroma (C-327/13). Practice has shown that the reality of companies may be far more complicated than what appears in formal documents and that legislation has to fit better to the concrete reality emerging during court trials so as to avoid fraudulent or abusive forum shopping practices (Tett, 2015).

The determination of the COMI of individuals is a problematic issue. Individuals can relocate their activities and residence very easily and rapidly and, in fact, the fast and easy transportation system of the European Union has made it quite normal for EU citizens to have their habitual residence in a different state that the state in which they undertake economic activities. Hence, the Recast has presumed the COMI to be the place of the individual's principal place of business or professional activity, while for a private individual who has ceased the exercise of a business or professional activity, the COMI is presumed to coincide with the habitual residence (Wessels, 2009). As to the complicated matter of groups of companies, the first version of the EIR was drafted only considering single companies. This fact created some significant problems in the interpretations of norms, which has been previously explained.

The EU legislator did not set the COMI for groups of companies properly. It kept a low profile. It did not determine rules that could establish which court has jurisdiction in the event of the insolvency of groups. More humbly, in the new Section V of the EIR, the EU legislator opted for coordination of proceedings involving different companies from the same group. It is now possible to establish cooperation among proceedings when faced with a plurality of insolvency proceedings of companies that are members the same group. Such cooperation is strictly voluntary. It can be requested by $75 \%$ of the insolvency office holders of the proceedings. It is at the time of the request that the court with responsibility for cooperation must be declared (Eidenmuller, 2013). 
In absence of a joint request, the rules state that the first court to be taken will be responsible for adjudicating the presence of requirements for opening such coordination. Coordination must be based on communication among the different insolvency office holders. In order to facilitate cooperation, the selected court has to nominate a new insolvency coordinator who cannot be selected from among the already existing insolvency office holders. Moreover, coordination can only start when coordination will most probably help in the positive conclusion of proceedings and when coordination does not create any prejudice with respect to any creditor (Tett, 2015). In the opinion of this author, coordination created by the Recast is still not enough. Furthermore, the conditions on which it is based are weak and its execution can be difficult because the rules as established are not as clear as they should be.

\section{Conclusions}

A solid and prosperous economy cannot ignore entrepreneurship. Entrepreneurship is a pivot for progress. Hence, it is important to prepare entrepreneurs for new challenges and provide them with a set of ideas regarding the status quo of insolvency regulations (Mathur, 2004). The common market is one of the pillars on which the European Union in built. As a consequence, entrepreneurs often carry on cross-border activates within the framework of the European Union and even beyond. This article is aimed at delineating the characteristics of EU insolvency regulation with the thought that entrepreneurs need to be familiar with the basics of EU cross-border insolvency law.

The common market has changed the economic business environment in Europe. Many companies have expanded exchange between states of the common market and they have, with increasing frequency, assets and establishments in different EU states. This directly impacts on the insolvency field as a relevant fraction of insolvency proceedings in Europe is related to companies involved in cross-border activities.

EU states jealously preserve their power on insolvency matters due to their political importance. States do not want to delegate their power on insolvency to the EU. This is the reason why the EIR Recast, as was the case of the previous version of the EIR, is not intended to create a set of substantive laws that could be applied across the EU. It includes significant innovations and it is important to notice that this reform does not modify the logic of the original Regulation. This Recast establishes a coherent set of 
rules that allow for an effective solution to collisions among jurisdictions ${ }^{14}$ in international insolvency matters.

The European Insolvency Regulation (EIR) is responsible for a giant leap forward in the effective administration of insolvency proceedings in the European Union (Wessels, 2013). Nevertheless, the Regulation cannot be the final step in this regard. One of its weaknesses is that it contains almost no rules harmonizing the national insolvency laws of the states. ${ }^{15}$

While waiting for the substantial harmonization of insolvency law, it is the opinion of this author that true and strong communication and cooperation are the most efficient way to avoid conflicts of jurisdiction, which affect the insolvency proceedings. Often, when an international insolvency proceeding is opened, the related information is not disseminated among the court authorities of the interested states. It is a very welcome novelization of the Recast that states that the court where an insolvency case was brought has to check whether it has jurisdiction.

Similarly, the creation of a EU insolvency database is a very positive tool that may help creditors throughout the European Union. Too many times judges were not informed about pending claims in other states and other judges did not know how to provide information about the starting of a proceeding. Simple questions such as what authorities should be contacted and how have now been answered, but the road to efficient European insolvency regulations is still long. The analysis of the effects of the Recast on secondary ancillary proceedings will be examined in the next article, which will be completely dedicated to ancillary proceedings after the Recast.

The future of entrepreneurship and insolvency are strongly related. Insolvency is slowly changing so as to become a tool fostering entrepreneurship as well as an entrepreneurial maintenance tool, not the preamble to bankruptcy. The second chance theory is finding its place in the European legal system. It must now be promoted among entrepreneurs. Every entrepreneur should master the main issues related to insolvency law just like an explorer needs to know the basics of survival before engaging in any exploration.

\footnotetext{
14 The EU legislator modified the EIR following the decisions of the ECJEU. The Annual Growth Survey 2015 of the EU.

15 In a number of areas, such harmonization would have been preferable, but attempts to achieve this turned out to be a bridge too far.
} 


\section{References}

Armour, J. and Cumming, D.J. (2007). Bankruptcy Law and Entrepreneurship. SSRN Scholarly Paper, No. ID 762144. Rochester, New York.

Ayotte, K. (2004). Bankruptcy and Entrepreneurship: The Value of a Fresh Start. SSRN Scholarly Paper, No. ID 463000. Rochester, New York.

Cumming, D.J. (2010a). Commentary: "Bankruptcy Laws and Entrepreneur Friendliness" and "How Do Bankruptcy Laws Affect Entrepreneurship Development Around the World?”. SSRN Scholarly Paper, No. ID 1639266. Rochester, New York.

Cumming, D.J. (2010b). Commentary: "Bankruptcy Laws and Entrepreneur Friendliness" and "How Do Bankruptcy Laws Affect Entrepreneurship Development Around the World?”. SSRN Scholarly Paper, No. ID 1639266. Rochester, New York.

Daniele, L. (2004). Il Regolamento N. 1346/2000 relativo alle procedure di insolvenza: spunti critici, in Dir. fall., I, 593.

Devece, C., Peris-Ortiz, M., and Rueda-Armengot, C. (2016). Entrepreneurship during Economic Crisis: Success Factors and Paths to Failure. Journal of Business Research, 69, 5366-5370.

Eidenmüller, H. (2006). Trading in Times of Crisis. European Business Organization Law Review.

Eidenmüller, H. (2013). A New Framework for Business Restructuring in Europe: The EU Commission's Proposals for a Reform of the European Insolvency Regulation and Beyond. Maastricht Journal of European and Comparative Law.

EUR-Lex - 52012DC0795 - EN - EUR-Lex [WWW Document] (n.d.). URL http://eur-lex. europa.eu/legal-content/EN/ALL/?uri=celex:52012DC0795 (accessed on October 28, 2016).

Feldam, M. (2014). The Character of Innovative Places: Entrepreneurial Strategy, Economic Development, and Prosperity. Small Business Economics.

Gladstone, B. and Lee, J. L. (n.d.). The Operation of the Insolvency System in the U.K.: Some Implications for Entrepreneurialism. Small Business Economics, 7, 55-66, http://dx.doi. org/10.1007/BF01074316.

Gunderson, G. (2007). The Founding Entrepreneurs: America's Prosperity. Social Education, $71,66$.

Jackson, T. (1986). The Logic and Limits of Bankruptcy Law. Harvard University Press.

Lai, L. (2011). Domestic Rules for Cross-Border Insolvencies Outside the EIR Framework in Italy and Poland. Substantive Harmonisation and Convergence of Laws in Europe. Papers from the INSOL Europe Academic Forum Annual Insolvency Conference, September 21-22, 2011, Venice, Italy.

Lai, L. (2012). A New Prospective for Saving Companies Intrinsic Values. In: S. Morawska (Ed.), Ekonomia i prawo upadłości przedsiębiorstw [Economics and company bankruptcy law] (pp. 281-289). Warszawa: Warsaw School of Economics Press.

Lee, S.-H., Peng, M.W., and Barney, J.B. (2007a). Bankruptcy Law and Entrepreneurship Development: A Real Options Perspective. ACAD MANAGE REV 32, 257-272, http://dx.doi. org/10.5465/AMR.2007.23464070.

Liddy-Murphy, R. (2015). Reformation of the European Insolvency Regulation to Act as a Legislative Tool to Assist in Europe's Growth Agenda. European Business Law Review, 26, 283-304. 
Mathur, A. (2009). A Spatial Model of the Impact of Bankruptcy Law on Entrepreneurship. SSRN Scholarly Paper, No. ID 2212988. Rochester, New York.

McCormack, G. (2012). Universalism in Insolvency Proceedings and the Common Law. Oxford Journal of Legal Studies, 32.

McCormack, G. (2014). Reforming the European Insolvency Regulation: A Legal and Policy Perspective. Journal of Private International Law, 10.

Omar, P. (2013). International Insolvency Law: Reforms and Challenges. London: Routledge. Regulation (EU) No. 2015/848 of the European Parliament and of the Council of May 20, 2015 on insolvency proceedings (recast). Official Journal of the European Union, L141, 19-72.

Paulus, P. (2006). The European Insolvency Regulation: The Case for Urgent Reform. Insolvency Intelligence.

Ringe, W. (2008). Forum Shopping Under the EU Insolvency Regulation. European Business Organization Law Review.

Røed, K. and Skogstrøm, J. F. (2014). Job Loss and Entrepreneurship. Oxford Bulletin of Economics and Statistics, 76, 727-744, http://dx.doi.org/10.1111/obes.12042

Sumner, G. (2009). Spatial Layout, Entrepreneurship and Economic Prosperity. Local Economy, 24, 502-522, http://dx.doi.org/10.1080/02690940903314894.

Tett, R. (2012). The recast EC Regulation on Insolvency Proceedings: A Welcome Revision. Corporate Rescue and Insolvency.

Wessels, B. (2012). International Insolvency Law, 3rd Edition, Deventer.

Wessels, B. (2009). Endin Coe Lecture. Insol-Europe Conference.

Wessels, B. (2010). Complementing the European Insolvency Regulation with Soft Law. Baden Baden: Nomos Verlag.

Council Regulation (EC) No. 1346/2000 of May 29, 2000 on insolvency proceedings. Official Journal L 160, 1-18.

Regulation (EU) 2015/848 of the European Parliament and of the Council of May 20, 2015 on insolvency proceedings of 20 May 2015.

The Annual Growth Survey 2015 of the European Union, http://ec.europa.eu/europe2020/ pdf/2015/ags2015_en.pdf.

(Case C-1/04) Staubitz-Schreiber, http://curia.europa.eu/juris/liste.jsf?language=en\&num= C- $1 / 04$.

(Case C-341/04) Eurofood, http://curia.europa.eu/juris/liste.jsf?language=en\&num=C-341/04.

(Case C-339/07) Deko Marty Belgium, http://curia.europa.eu/juris/liste.jsf?language=en\&num $=\mathrm{C}-339 / 07$.

(Case C-444/07) MG Probud, http://curia.europa.eu/juris/liste.jsf?language=en\&num=C-444/07.

(Case C-396/09) Interedil, http://curia.europa.eu/juris/liste.jsf?language=en\&num=C-396/09.

(Case C-191/10) Rastelli Davide, http://curia.europa.eu/juris/liste.jsf?language=en\&num $=C-191 / 10$.

(Case C-116/11) Bank Handlowy, http://curia.europa.eu/juris/liste.jsf?language=en\&num $=\mathrm{C}-116 / 11$.

(Case C-327/13) Illochroma, http://curia.europa.eu/juris/liste.jsf?language=en\&num=C-327/13. 


\title{
Sirojiddin Orifov*
}

\section{SME Development, Economic Growth, and State Intervention in a Developing Economy: The Uzbek Story}

\begin{abstract}
Uzbekistan, one of the post-Soviet states, has been in transition from a planned economy to a market one since its independence in 1991. Unlike many other post-Soviet states that chose a rapid transition approach, Uzbekistan pursues a gradual transition. The smalland medium-enterprise (SME) sector holds a majority share in the economy as well as economic sectors by contributing to the on-going high GDP growth rate of Uzbekistan over last few years. Facets of entrepreneurship and SME development in Uzbekistan have been researched previously in an entrepreneurship-related transitional economy context. However, this does not reflect the dynamics of SME sector development over recent years in Uzbekistan's transitional economy. A dearth of information on the dynamics of SME sector development hinders analysis of the formation and growth of SMEs in Uzbekistan since 1991. The paper explores the emergence of the SME sector and economic development in Uzbekistan as of its independence by using the existing statistical information and panel data obtained by the author from the State Statistics Committee of Uzbekistan for the recent years. The aim of the paper is to examine the relationship between economic growth, SME development, and government support in Uzbekistan.
\end{abstract}

Keywords: SMEs, GDP per capita, developing economy, government support expenditure, entrepreneurship, Uzbekistan.

Rozwój małych i średnich przedsiębiorstw, wzrost gospodarczy i interwencja państwowa w rozwijającej się gospodarce - przypadek Uzbekistanu

Uzbekistan, jako jedno z poradzieckich państw, od momentu osiągnięcia niepodległości w 1991 roku znajduje się w stanie transformacji z gospodarki planowej do rynkowej. W odróżnieniu od wielu innych tego typu państw, które wybrały szybką transformację, Uzbekistan dąży do łagodnego przejścia. Sektor małych i średnich przedsiębiorstw ma największy udział w gospodarce i sektorach gospodarki mający udział w ciągłym wysokim wzroście PKB Uzbekistanu. Dotychczasowe badania przedsiębiorczości oraz rozwoju małych i średnich przedsiębiorstw w Uzbekistanie w kontekście przejściowych gospodarek nie odzwierciedlają dynamiki sektora małych i średnich przedsiębiorstw ostatnich lat

* Sirojiddin Orifov, Ph.D. Candidate - Kozminski University; ul. Jagiellońska 57/59, 03-301 Warsaw; e-mail: 999-PhDM@kozminski.edu.pl. 
w przejściowej gospodarce Uzbekistanu. Brak informacji dotyczącej dynamiki rozwoju sektora małych i średnich przedsiębiorstw hamuje analizę powstawania i rozwoju takich przedsiębiorstw w Uzbekistanie od roku 1991. W artykule poddano badaniu, za pomocą istniejącej informacji statystycznej, pojawienie się sektora małych i średnich przedsiębiorstw oraz rozwój gospodarczy w Uzbekistanie od niepodległości oraz dane panelowe uzyskane od Uzbeckiego Komitetu Państwowego ds. Statystyk dotyczące ostatnich lat. Celem artykułu jest odkrycie powiązań pomiędzy rozwojem gospodarczym, rozwojem małych i średnich przedsiębiorstw oraz wsparciem państwa w Uzbekistanie.

Słowa kluczowe: małe i średnie przedsiębiorstwa, PKB per capita, rozwijająca się gospodarka, wsparcie państwowe, przedsiębiorczość, Uzbekistan.

JEL: L26, O47

\section{Introduction}

Uzbekistan is considered as one of the Central Asian countries boasting high economic growth potential. The country is located in the heart of Eurasia and is strategically positioned in Central Asia. It is a "double landlocked" state, which creates logistics issues in the international trade. Uzbekistan has developed the best road and rail network infrastructure in Central Asia out of what it inherited from its Soviet past. (ADB, 2005) It has the largest population in Central Asia with over thirty million people, making it a country with high human potential (State Statistics Committee, 2015). The government of Uzbekistan took a gradual transition path from early independence years, in comparison with the "shock therapy" transition chosen by some other former Soviet states-e.g., Russia and Kazakhstan (Kan, 2015). At the same time it was included along with Turkmenistan and Belarus as a "transition laggard" by Lane (2007). Uzbekistan managed to be the first state in Commonwealth of Independent States (CIS) to return a positive real growth rate in 1996. (ADB, 2005) The development of SMEs was placed as a core of Uzbekistan's economic transformation model as a solution to shortages of consumer goods and the inefficient distribution of resources in the economy (Smallbone and Welter, 2010).

An overall increase in entrepreneurial activity can be observed in many developing countries-e.g., Uzbekistan (Bradley and Klein, 2016; Bruton, Ahlstrom, and Obloj, 2008). In contrast to this, a decrease in entrepreneurial dynamism is seen in the United States as of the 1970s. There is also an on-going effort by some of the European states to build an entrepreneurial culture (Bradley and Klein, 2016) Theoretical developments in entrepreneurship have moved forward while empirical research is behind 
with its slow pace as it lacks sufficient data. The Global Entrepreneurship Monitor, which includes data for eighty-five countries, and the Panel Study of Entrepreneurial Dynamics in the United States have partially contributed to offset this insufficiency of data. However, these empirical research projects do not encompass all transitional regions (Reynolds 2007; Vivarelli, 2013). Entrepreneurship is an attractive topic for researchers in various fields as it is a multi-dimensional phenomenon. Most of the literature on entrepreneurship is highly focused on business creation and on research into the processes of making a first entry into business by entrepreneurs (Nikolova and Simroth, 2013). Researchers into entrepreneurship are encouraged to systematically examine the impact of state policy on entrepreneurship at various levels (Zahra, Wright, and Abdelgawad, 2014). In general, policymakers and researchers equally support the importance of entrepreneurship on the social-economic and political scene of life (Bradley and Klein, 2016). However, there is a variance in the definition of entrepreneurship's composition and emergence.

Currently, private entrepreneurship is divided into three sectors in Uzbekistan: individual entrepreneurship, the small- and medium-enterprise (SME), and the large enterprise sectors. Certain general aspects of the SME sector as well as private entrepreneurship have been researched in Uzbekistan and presented in a few sources (Kalmurzaev, 2000; Pomfret, 2000; Eshee et al., 2002; Majidov, 2007, Salayev, 2008; Kan, 2010; Elo, 2016). At the same time, Uzbekistan is generally included in research papers on entrepreneurship in transition economies (Smallbone, 1996; Hubner, 2000; Smallbone and Welter, 2001; Estrin et al., 2005; Aidis, 2006; Smallbone and Welter, 2010; Nikolov and Simorth, 2013; Kan, 2015). Available literature does not cover private entrepreneurship and SME sector development from the early independence years to present times in a sequential manner. Moreover, there are no academic papers or reports in literature on the emergence of entrepreneurship or the composition of the SME sector in Uzbekistan. Khalmurzaev (2000) mentioned the scarcity of SME data and complications that any analysis entails. Up to recent years there was a lack of statistical data on the share of SMEs in total employment as well as other macro-environmental data. These factors are responsible for limiting research on the formation and development of SMEs in the transition period of Uzbekistan in any extended form.

The purpose of this paper is to make a contribution to the identification of the interrelationship among SME sector growth, GDP growth, and state support by identifying the correlations for: (i) The affect of GDP per capita growth on SME population trends, and (ii) the effect of state support on SME sector growth. The first chapter of this article analyzes SME sector development 
in Uzbekistan, followed by theories on economic growth, government support, and SME development. This will be followed by the methodology and results sections. Discussion and conclusions may be found at the end.

\section{Overview of SME Sector Development}

\subsection{Legal Framework and Definition of SMEs in Uzbekistan}

The first regulation of enterprises was introduced by the Law of the Republic of Uzbekistan and the Decree of Cabinet of Ministers "On Measures for the Continuous Development of Enterprise Activity" of February 15, 1991. These laws established the regulative norms covering all enterprises at that time, including the commercial operations of private businesses in Uzbekistan. The initial law on enterprises lacked any classification of business activities by SMEs, leaving it for government authorities to determination the business activity of an enterprise on an individual basis (Kan, 2015). The inclusion of Article 53 in the Constitution of Republic of Uzbekistan in 1992 marked the recognition of entrepreneurship on a national-scale: "The economy of Uzbekistan, evolving toward market relations, is based on various forms of ownership. The state shall guarantee freedom of economic activity, entrepreneurship, and labor with the regard for the priority of consumer rights as well equal and legal protection of all forms of ownership" (Eshee et al., 2002, p. 3). This article of the Constitution guarantees the right of Uzbek citizens to conduct entrepreneurial activities. A basic initial law is an important foundation in the guaranteeing of business freedom in the economy. The first few years of independence saw a series of new laws and decrees concerning the development and acceleration of entrepreneurship in Uzbekistan adopted and implemented. Nine decrees were issued by the President of Uzbekistan in the first decade of independence, as were sixteen resolutions by the Cabinet of Ministers of Uzbekistan (Eshee et al., 2002).

There are several ways to classify small businesses. They can be based on total assets, annual sales, annual profits, or the number of employees, and in some cases a combination of these characteristics. The Decree of Cabinet of Ministers "On Measures for the Development of Entrepreneurship" of 1992 chose the number of employees as the criterion for classification of small businesses in Uzbekistan (Khalmurzaev, 2000). Subsequently, a 1994 Decree by President Karimov focused on "private property protection and development." As a consequence, a national business fund and insurance agency were established the following year for the improvement of access to financing 
and protection for SMEs. The National Chamber of Entrepreneurs and Manufacturers of Uzbekistan was formed in 1996. Its purpose is to provide informational and consultancy services for private businesses. Three decrees were issued between 1997 and 2000 in support of private entrepreneurship, a reduction of government interference with business activities, and economic liberalization programs. The Decree of the President of Uzbekistan of April 11, 1998 impacted on the characteristics of SME support activities. It specified a legal definition for SME organizations as well as customs duty and tax privileges for SMEs. For example, technological equipment for inhouse production imported by SMEs is exempted from customs duties. At the same time, SMEs in small towns and villages in the construction and production sectors received tax privileges (Hubner, 2000).

Small businesses in Uzbekistan are classified in accordance with their number of employees and sector of activity. This classification of small business enterprises and organizations was modified by the Decree of President of Uzbekistan of May 2, 2012 on "Guarantees for Freedom of Entrepreneurial Activity." According to this Decree, small business received the following legal definition: individual entrepreneurs, micro and small enterprises (see Table No. 1). There is no legal definition for medium-sized enterprises. All business entities larger than small enterprises are considered large enterprises. No regulation of the capital investment ratio was imposed by the latest decree (Lex Uz., 2014). According to ADB (2012), changes in the definition of the private business subsectors from micro, small- and medium-enterprises

Table No. 1. Classification of enterprises and organization related to small business entities in Uzbekistan

\begin{tabular}{|l|c|c|}
\hline 1. Forms of activity & \multicolumn{2}{|c|}{$\begin{array}{r}\text { Individual entrepreneur, micro } \\
\text { and small enterprise }\end{array}$} \\
\hline 2. Number or employees (people) & Micro enterprise & Small enterprise \\
\hline Manufacturing and mining & $1-20$ & $21-50$ \\
\hline Services and non-manufacturing sectors & $1-10$ & $11-25$ \\
\hline Retail, wholesale and catering & $1-5$ & $6-25$ \\
\hline Textile, food and construction materials industry & $1-20$ & $21-200$ \\
\hline Metal and wood processing, furniture industry & $1-20$ & $21-100$ \\
\hline $\begin{array}{l}\text { Agriculture, machinery, heavy and chemical } \\
\text { industry }\end{array}$ & $1-20$ & $21-50$ \\
\hline $\begin{array}{l}\text { Transport, communication, retail and science/ } \\
\text { academic sphere }\end{array}$ & $1-5$ & $6-25$ \\
\hline
\end{tabular}

Source: Created by the author, based on Lex Uz (2003) 
to micro and small-enterprises is intended to improve monitoring and the compiling of statistics.

\subsection{Stages of Reform in the Private Entrepreneurship Sector}

Uzbekistan declared its independence in 1991, following the collapse of the Soviet Union. Each of the former Soviet republics started to adopt political changes aimed at the establishment of the democratic rule of law. Reforms focused on an emergence of a market economy out of a planned one. This required allocation of resources to create economic balance: from local to global manufacturing, from semi-finished products to final goods, and from the manufacturing to the service sector. A planned economy model was the core of former socialist economies, which were highly "industrialized" with around a $45-50 \%$ share of industry in GDP. Furthermore, socialist economies were concentrated on trade within the communist bloc, rather than trade with capitalist economies. The initial reforms started to open opportunities for international trade and business activity in the service sector. At the same time, the privatization of former industrial enterprises-a transitional reform-improved governance and an efficient allocation of resources (Estrin, Meyer, and Bytchkova, 2005).

Uzbekistan has chosen a gradual economic transition model, while Russia and Kazakhstan adopted a "shock therapy" transition stage. Unlike the transition model of Russia and Kazakhstan aimed at rapid transformation and massive privatization, Uzbekistan has maintained a major share of the economy as a state-owned sector (Kan, 2015). Uzbekistan's economic transformation model chose the development of SMEs as the solution to its shortage of consumer goods and inefficient distribution of resources in the economy (Smallbone and Welter, 2010). Salayev (2008) developed a table with five stages of SME sector development in Uzbekistan from 1989 to 2010 (see Figure No. 1). A review of macroeconomic policies, legislation, and institutional changes shows that SME development has gone through three main stages during the first decade. The following part of this paper will apply these SME sector development steps in the Uzbekistan structure to present SME sector development trends in a sequence.

Figure No. 1. SME sector development steps in Uzbekistan

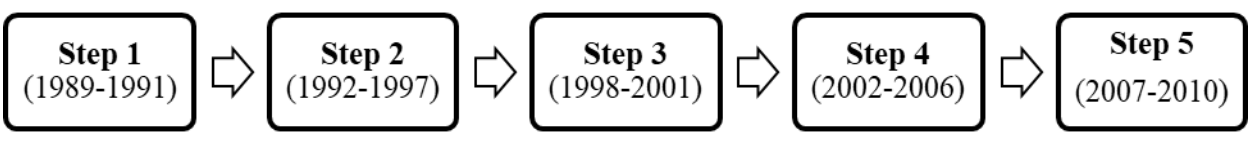

Source: Created by the author, based on the figure provided by Salayev (2008, p.15) 


\subsubsection{SME Development Trends between Stage I and Stage III (1991-2001)}

After the collapse of the Soviet Union, the once monopolistic state enterprises were forced to face many serious problems, including a rapid decrease in production capacity, dependence on state subsidies, a lack of sufficient capital investment, and X-inefficiency as a holdover from state intervention. State enterprises that were once the "locomotives of the economy," started slowing down in the transition period (Kan, 2010). The many market gaps left open by state-owned enterprises and access to bank loans at favorable rates made this a particularly favorable period for new enterprise creation. At the same time, low salaries and wages for the qualified workforce at large state enterprises served as an opportunity to attract employees to private enterprises through monetary reward. Economists and policymakers stress the significant role played by the newly established enterprises in the rapid recovery of the economy in this first attempt at transitioning to a market one. This was thanks to the dynamism and flexibility of the new enterprises (Smallbone, 1996; McIntyre, 2001; Baumol, 2004). Newly established businesses in the transitional economy contributed with new technological innovations and employment creation. They stimulated the promotion of competition in the economy, which lowers X-inefficiency and balances the distribution of economic resources (Gibb, 1995; UN, 1999). Furthermore, de novo new enterprises help not only in the reduction of consumer goods deficiency and an improvement of imbalance in the pricing systems, but also facilitate the privatization of Former State Enterprises (FSEs) (Smallbone and Welter, 2001; Svejnar, 1991).

During the first stage (1989-1991), the main focus of SMEs was mostly on communal services and housing construction, catering, and the manufacture of consumer goods. According to Salayev (2008), new laws and decrees relating to the formation of private businesses were adopted after the declaration of independence. However, there was a lack of infrastructural facilities and institutional support for small businesses. The second stage (1991-1995) started with initial legislative reforms on the liberalization of non-state sector business legal status-from individual entrepreneurship to stock companies (Khalmurzaev, 2000). At the same time, an initial liberalization of the economy and privatization was launched through the application of market economy reforms. The following organizations for support of small businesses were established: the Business Fund, the Madad Insurance Agency, the Tadbirkorbank Bank, and business schools and business incubators. However, there were still many gaps in some economic sectors, even with the involvement of private businesses, where a majority of active companies were operating in the trade sector during this period (Salayev, 2008). 
By the third stage (1995-99), the economy of Uzbekistan had achieved macroeconomic stability and economic growth. New economic reforms introduced tax reductions for small businesses, an adoption of new private business classification legislation, and growth in the share of the SME sector in the GDP (Salayev, 2008). SME support organizations started to actively support SMEs. Some large-scale private entrepreneurship support programs were launched by foreign organizations-e.g., TACIS, EBRD, and others (Khalmurzaev, 2000). However, there was an increase in the number of bankruptcies and liquidation of business entities (Salayev, 2008). The numbers of SMEs increased gradually up to 1999 (see Figure No. 2) when farming entities (fermerskie khozyastvo) were established as legal entities and were allowed to employ workers (Kan, 2010). After 1999, agriculture sector reforms served as a foundation for the growth of SMEs overall and resulted in an increase in the employment in SME sector.

Figure No. 2. Number of SMEs and number of persons employed in the SMEs sector in stage I-III

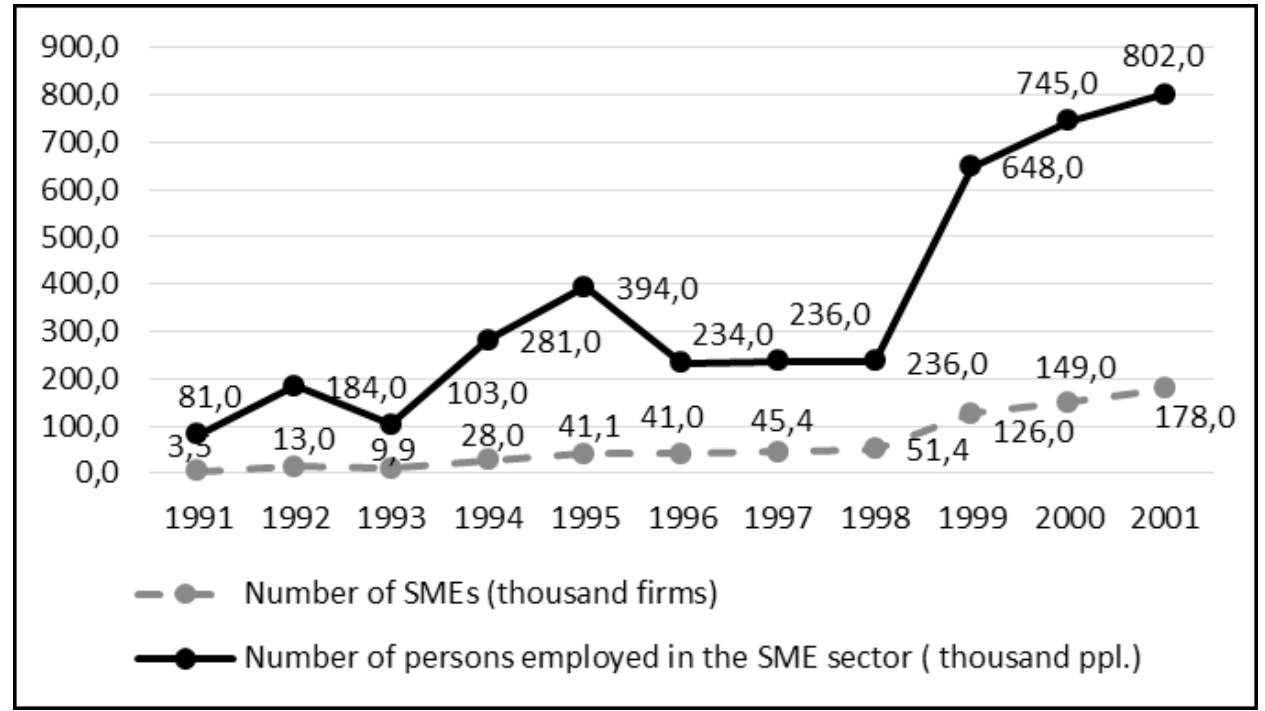

Source: Created by the author, based on statistical information by Kan $(2015$, p.34)

The post-Soviet states had to launch transitional reforms oriented towards economic liberalization, democratization, and privatization. Uzbekistan chose the gradual transition approach. This was unlike many other postSoviet states that pursued a "shock therapy" approach. It was for this reason that the privatization of large-scale FSEs of strategic importance to the industrial complex did not go forward until 2000. These large FSEs-the 
backbone of economy-were primarily in the mining, communication, and manufacturing sectors. However, there was what was known as the "small privatization" of state-owned SMEs in the construction and the food and beverage sectors between 1992 and 1998 (Kan, 2010). This privatization process started with rapid growth in 1995, when over 7,500 entities were privatized and over 1,000 enterprises were transformed into joint venture (JV) companies (see Table No. 2). Starting with 1996, the total number of privatizations decreased sharply to 1,915 enterprises and the composition also changed (658 entities were privatized and 1,257 enterprises were transformed into JVs). As a consequence, Uzbekistan was behind in privatization, liberalization, and market reforms as compared to other transition countries. It was also lagging in the establishment of proper market infrastructure (Pomfret, 2000).

Table No. 2. Privatization trend in early stages of SME sector development

\begin{tabular}{|c|c|c|c|}
\hline \multirow{2}{*}{ Years } & \multirow{2}{*}{ Total } & Including \\
\cline { 3 - 4 } & & Privatized & $\begin{array}{c}\text { Converted into } \\
\text { Joint Stock } \\
\text { Companies }\end{array}$ \\
\hline 1995 & -- & 7511 & 1026 \\
\hline 1996 & 1915 & 658 & 1257 \\
\hline 1997 & 1231 & 443 & 788 \\
\hline 1998 & 451 & 103 & 110 \\
\hline 1999 & 448 & 156 & 141 \\
\hline
\end{tabular}

Source: Kan (2010, p.28)

\subsubsection{SME Sector Development Trends in Stages IV and V (2000-2010)}

Lex Uz. (2003) includes the Decree with new changes in the qualification of SMEs. In it, the medium-sized enterprise was removed from legislation and a micro firm category was added to the classification of private enterprises. This was in 2004. From that year on, private enterprises were registered at a single business registry using the new classification system. At the same time, licensing, patents, and standardization systems were introduced by the state. During the fourth stage, the share of SMEs in the GDP increased and the distribution of SMEs spread, balancing service, trade, and other sectors (Salayev, 2008). 
Figure No. 3. Share of private entrepreneurship in GDP and total employment (excluding farming entities; on $1^{\text {st }}$ January; in percentage)

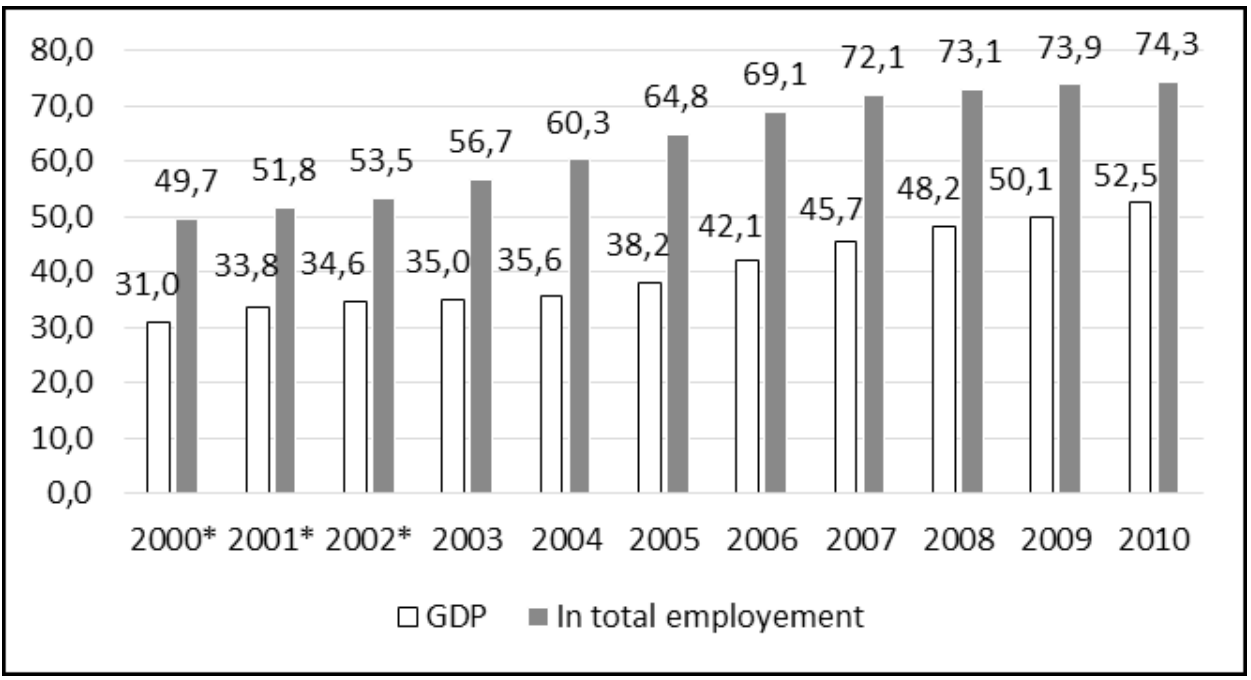

*2000-2003 SME classification based on the active classification legislation of that period. Source: Created by the author, based on statistical information given in CER (2013, p. 155)

Figure No. 4 Share of SMEs and individual entrepreneurs in GDP (excluding farming entities; on $1^{\text {st }}$ January; in percentage)

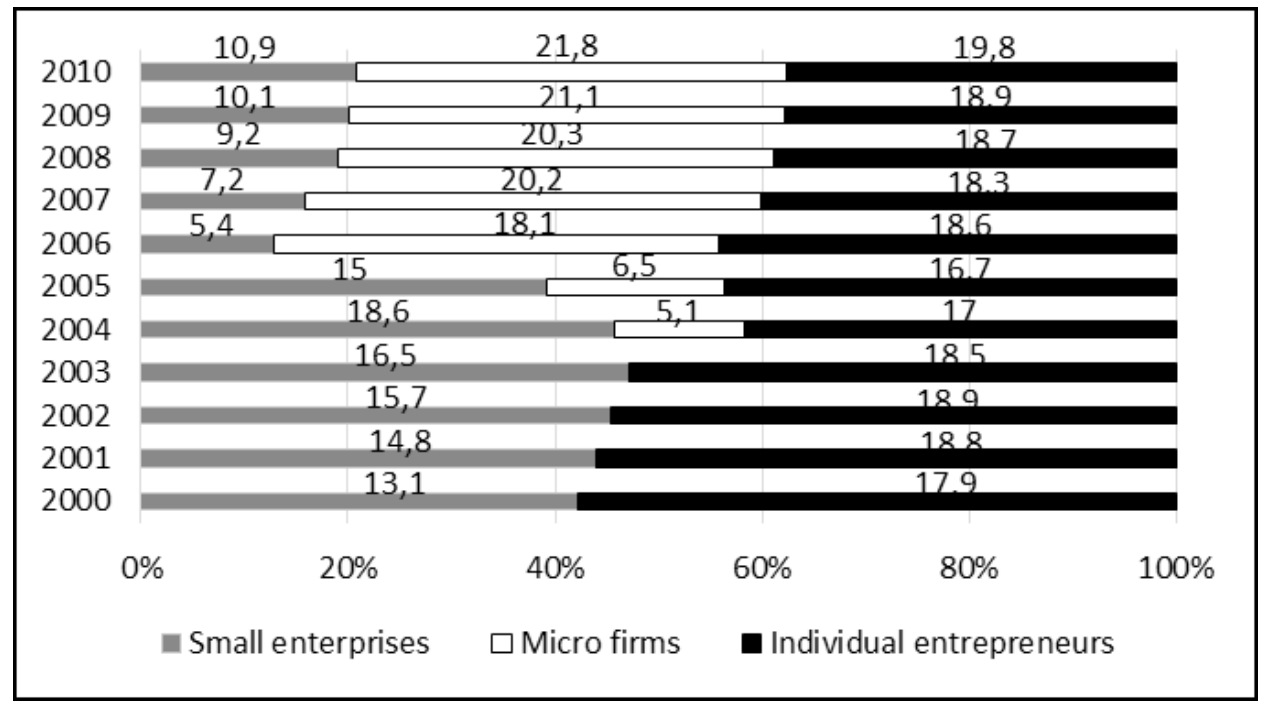

Source: CER (2011, p. 59) 


\begin{tabular}{|c|c|c|c|c|c|}
\hline 응 & $\begin{array}{l}\text { ma } \\
\text { mे }\end{array}$ & $\begin{array}{l}n \\
\infty\end{array}$ & $\underset{\forall}{\stackrel{\sim}{*}}$ & $\begin{array}{l}\sigma \\
\dot{0} \\
o \\
+ \\
+\end{array}$ & $\begin{array}{l}\vec{b} \\
\infty \\
\infty\end{array}$ \\
\hline ஓे & $\begin{array}{l}\text { No } \\
\text { ஸे } \\
\text { ñ }\end{array}$ & $\vec{\infty}$ & $\stackrel{\text { }}{\text { nे }}$ & $\begin{array}{l}\infty \\
\infty \\
0 \\
0 \\
గ ్ \\
0\end{array}$ & $\hat{\sigma}$ \\
\hline $\begin{array}{l}\infty \\
\stackrel{\bigcirc}{\bigodot}\end{array}$ & $\begin{array}{c}\text { ă } \\
\hat{\sigma}\end{array}$ & $\ddot{\sigma}$ & $\begin{array}{l}\vec{\infty} . \\
\dot{n}\end{array}$ & $\begin{array}{l}\infty \\
\infty \\
+ \\
\stackrel{D}{\lambda} \\
\text { }\end{array}$ & 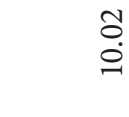 \\
\hline હે̊ & $\begin{array}{l}\overline{\widetilde{N}} \\
\stackrel{\mathrm{N}}{ }\end{array}$ & นn & $\underset{+}{\stackrel{+}{+1}}$ & 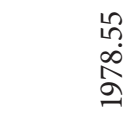 & $\stackrel{\widehat{N}}{=}$ \\
\hline 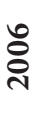 & $\begin{array}{l}m \\
\stackrel{0}{0}\end{array}$ & $\stackrel{n}{\sim}$ & $\begin{array}{l}\text { ๙ু } \\
\text { ஸे }\end{array}$ & $\begin{array}{l}\infty \\
\dot{0} \\
\stackrel{\leftrightarrow}{+}\end{array}$ & $\stackrel{f}{\stackrel{f}{二}}$ \\
\hline ¿̊ & $\vec{m}$ & $\stackrel{\circ}{1}$ & $\begin{array}{l}\hat{b} \\
\stackrel{i}{ }\end{array}$ & 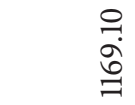 & 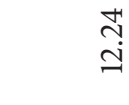 \\
\hline ঠ্ণী & $\begin{array}{l}\text { O̊ } \\
\text { İ }\end{array}$ & 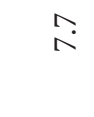 & $\begin{array}{l}\text { O) } \\
\stackrel{4}{i}\end{array}$ & $\begin{array}{l}\infty \\
\text { ஸ் } \\
\hat{\sigma}\end{array}$ & $\stackrel{n}{\tilde{n}}$ \\
\hline ְ̊요 & $\stackrel{m}{0}$ & $\stackrel{\sim}{\sim}$ & $\stackrel{\overbrace{}}{\sim}$ & $\begin{array}{l}8 \\
8 \\
\infty \\
\infty \\
\infty\end{array}$ & $\stackrel{\widetilde{N}}{\Perp}$ \\
\hline ్ㅗㅇ & $\begin{array}{l}\hat{b} \\
\text { aे }\end{array}$ & $\stackrel{\circ}{+}$ & $\underset{\sim}{\stackrel{\sim}{\sim}}$ & $\begin{array}{l}\vec{b} \\
\dot{0} \\
\hat{0}\end{array}$ & 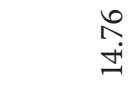 \\
\hline ठ্ণ & $\stackrel{\stackrel{9}{+}}{=}$ & $\stackrel{\sim}{+}$ & $\begin{array}{l}\stackrel{\sim}{O} \\
\text { i }\end{array}$ & $\begin{array}{l}\text { f } \\
\stackrel{5}{*} \\
\stackrel{f}{4}\end{array}$ & $\begin{array}{l}\stackrel{m}{\sim} \\
\stackrel{\sim}{0}\end{array}$ \\
\hline ঠి & 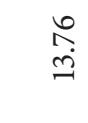 & $\stackrel{\infty}{\dot{m}}$ & $\stackrel{\Omega}{\sigma}$ & 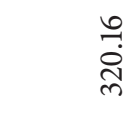 & $\stackrel{\infty}{\stackrel{\sim}{\sim}}$ \\
\hline & 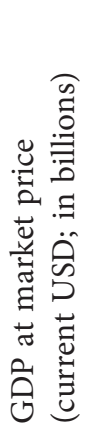 & 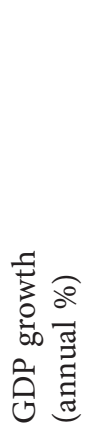 & 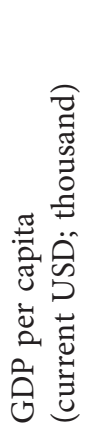 & 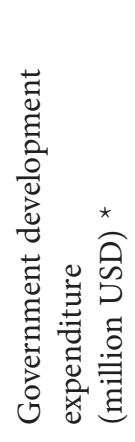 & 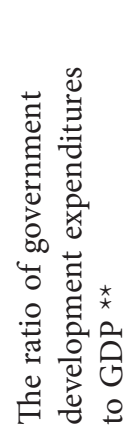 \\
\hline
\end{tabular}


The share of private entrepreneurship amounted to 31\% of the GDP in $2000-13.1 \%$ as small-enterprises and $17.9 \%$ as individual entrepreneurship. Meanwhile, 182,900 SMEs were registered, where 149,300 were active (see Figure No. 3 and Figure No. 4). The upward trend was seen in the growth of the share of private entrepreneurship up to 2003. The proportion of small enterprises and micro firms was steady with a slightly greater share of individual entrepreneurship. Starting with 2004, the qualification of employer enterprises changed and the micro firm category was added, while at the same time the medium-sized enterprise category was removed from the qualification (Lex Uz., 2004). In that year the total share of private entrepreneurship accounted for $35.6 \%$ of which $18.6 \%$ were small-enterprises, $5.1 \%$ were micro firms, and $17 \%$ were individual entrepreneurship (see Figure No. 4). Over the following years the total proportion of input by private entrepreneurship remained steady with some marginal growth. Composition by category of private entrepreneurship changed through the rapid increase of micro firms in their share in the GDP and a decrease in small enterprises. Voluntary liquidation of entities and resource procurement procedures were simplified in the fifth stage. Furthermore, export sales tax was reduced and technological modernization started in the private sector. Moreover, the "Increasing Employment of the Population, Support for Small Entrepreneurship, and Development in 2007-2010" program was launched in regions of Uzbekistan (Salayev, 2008). In 2010, micro enterprises accounted for $21.8 \%$ of the GDP as compared with $10.9 \%$ for small enterprises and $19.8 \%$ for individual entrepreneurship (depicted in Figure No. 3). The economic growth indicators are provided in Table No. 3 and show that the economy of Uzbekistan has marginally increased its GDP growth rate, reaching over $8 \%$ by 2010 . At the same time, the GDP per capita also grew marginally. Government development expenditure also followed the GDP growth trend.

\subsection{Recent SME Development in Uzbekistan}

\subsubsection{The Demography of SMEs}

The number of registered SMEs increased gradually from 205,200 in 2011 to 243,800 in 2015 (see Figure No. 5). At the same time, the number of active SMEs also increased gradually, however at a slower pace (approximately 21,000 entities) than the number of registered SMEs. In 2015, around $80 \%$ of registered SMEs were operating on the market. A majority of the active SMEs were in the trade and catering sectors. This number included over 57,000 micro firms and almost 9,000 small enterprises. Another 
major group of SMEs is active in the industrial sector, with almost 40,000 micro firms and 2,600 small enterprises. Industrial policy has been the core of Uzbekistan's development strategy. Its target is the establishment of a modern and diversified economy. Industrial policy is concentrated on an import-substitution strategy in order to provide for the self-sufficiency of the domestic market and as well as exports to foreign ones (ADB, 2005). At the same time, small enterprises are active in non-production forms of services, where there were over 7,000 of them. In general, micro firms are growing in number and forming the majority in SMEs' demography. Applying numbers of employees and sector entity operation based identification to ascertain the types of SMEs in Uzbekistan, it can be concluded that the development of micro firms into small enterprise is slow.

Figure No. 5. The number of registered and the number of active small enterprises and micro firms (excluding farming entities; on 1th January; thousand enterprises)

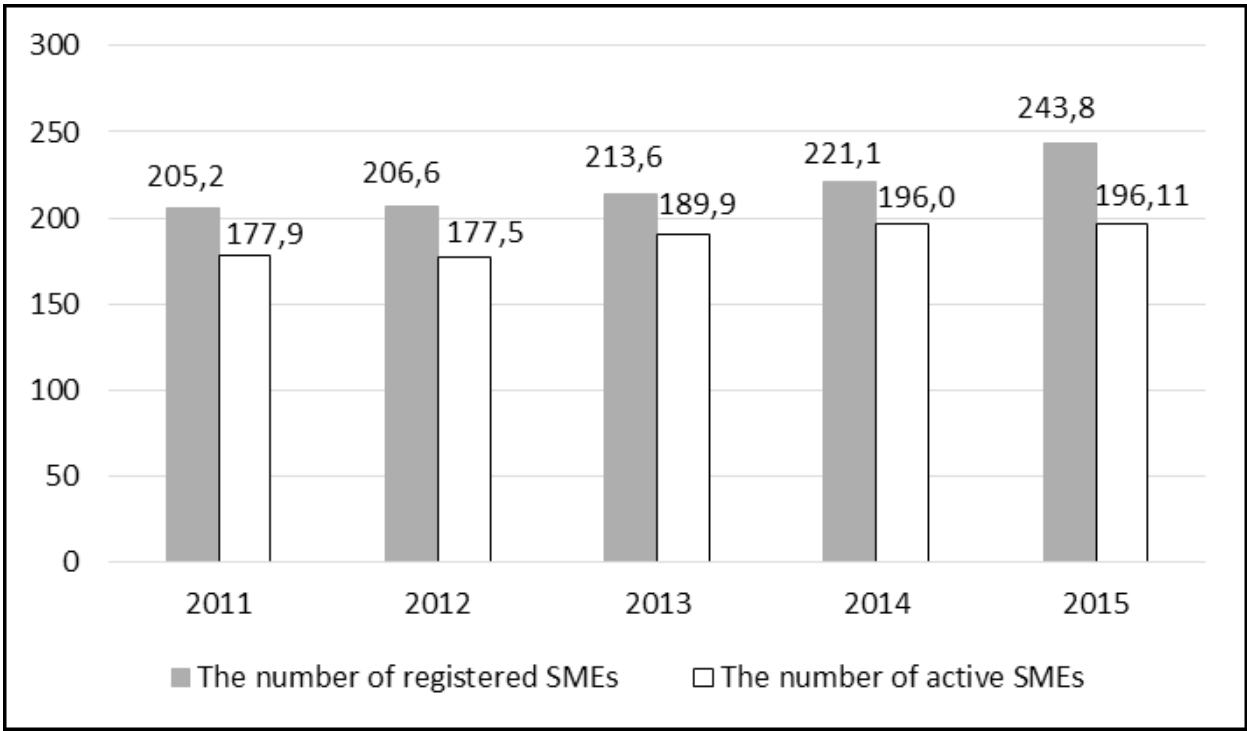

Source: Created by the author, based on statistical information give in State Statistics Committee of Uzbekistan (2015a, p.71)

\subsubsection{Contribution of SMEs to the Main Economic Sectors}

The share of SMEs in the GDP of Uzbekistan has continued its upward trend over recent years with an increase from 54\% in 2011 to $56.1 \%$ in 2014 (see Table No. 4). At the same time, the share of SMEs in industry has increased by $10 \%$ over four years (from $21.9 \%$ to $31.7 \%$ ). In key sectors of the economy, SMEs hold a major share and that share has been increasing 
gradually. In agriculture $(98.3 \%)$, trade $(86.3 \%)$, and passenger transportation $(85.7 \%)$ in 2014 , SMEs gained a majority share in these sectors. The share of SMEs in total employment has gone up gradually from $75 \%$ to $77.6 \%$ over the recent four years. SMEs' role in foreign economic activities has been considerable, especially in imports, where SMEs' share increased from $34.3 \%$ to $45.4 \%$ over four years. At the same time, the share of SMEs in exports has also grown, albeit marginally, and accounted for a total of $25 \%$ in 2014. Economic growth figures continue to point to a high growth rate in GDP, but GDP per capita grew at a slower pace.

Table No. 4. Contribution of SMEs in main economic indicators (in percentage)

\begin{tabular}{|l|c|c|c|c|}
\hline & $\mathbf{2 0 1 1}$ & $\mathbf{2 0 1 2}$ & $\mathbf{2 0 1 3}$ & $\mathbf{2 0 1 4}$ \\
\hline Gross domestic product (GDP) & 54.0 & 54.6 & 55.8 & 56.1 \\
\hline Industry & 21.9 & 23.1 & 28.1 & 31.7 \\
\hline Agriculture & 97.9 & 97.8 & 98.0 & 98.3 \\
\hline Investments & 31.9 & 35.3 & 32.7 & 35.4 \\
\hline Construction & 68.6 & 71.1 & 71.5 & 69.5 \\
\hline Trade & 86.7 & 87.3 & 86.6 & 86.3 \\
\hline Paid services & 46.3 & 44.9 & 46.2 & 48.6 \\
\hline Logistics & 43.2 & 44.2 & 47.3 & 49.8 \\
\hline Passenger transportation & 81.8 & 83.1 & 84.5 & 85.7 \\
\hline Employment & 75.1 & 75.6 & 76.7 & 77.6 \\
\hline Exports & 18.8 & 14.0 & 26.2 & 25.9 \\
\hline Imports & 34.3 & 38.6 & 42.4 & 45.4 \\
\hline
\end{tabular}

Source: Created by the author, based on State Statistics Committee of Uzbekistan (2015a, p. 18)

Table No. 5. Economic growth indicators (2011-2014)

\begin{tabular}{|l|r|r|r|r|}
\hline & \multicolumn{1}{|c|}{$\mathbf{2 0 1 1}$} & \multicolumn{1}{c|}{$\mathbf{2 0 1 2}$} & \multicolumn{1}{c|}{$\mathbf{2 0 1 3}$} & \multicolumn{1}{c|}{$\mathbf{2 0 1 4}$} \\
\hline GDP at market price (current USD; in billions) & 45.32 & 51.18 & 56.79 & 62.64 \\
\hline GDP annual (\%) & 8.3 & 8.2 & 8.0 & 8.1 \\
\hline GDP per capita (current USD; thousand) & 4.59 & 5.00 & 5.46 & 5.83 \\
\hline $\begin{array}{l}\text { Government development spending (million } \\
\text { USD) }\end{array}$ & 5682.4 & 7094.37 & 8773.99 & 10127.10 \\
\hline $\begin{array}{l}\text { The ratio of government development } \\
\text { expenditures to GDP ** }\end{array}$ & 7.97 & 7.21 & 6.47 & 6.14 \\
\hline
\end{tabular}

Source: World Bank (2016); ${ }^{\star}$ ADB (2016); ${ }^{\star \star}$ Based on the author's calculations 


\section{SME Development, Economic Growth, and Government Support of the SME Sector}

SME sector growth is reflected in GDP growth, industrial output, and sectorial composition. At the same time, it is related to state support and economic development in general. Considering these aspects, two questions are addressed in this paper:

1. Does GDP per capita growth affect SME population trends?

2. Is government support essential for growth of the SME sector?

\section{1. "Traditional" Paradigm}

In the literature that is available, it is the works of Hoselitz (1959), Finnie et al. (1965), and Anderson (1982) that grab attention because they highlight the "traditional" theories of SME development. There was a dominance of craftsmen over industry in the early stages of economic development during the industrialization of Germany. Later, most of that industry developed into today's larger industrial establishments while the traditional branches of industry came to their end (Hoselitz, 1959). General growth stage typologies were introduced by Burke (1979) and Anderson (1982) and are applicable in the case of industrialized economies on a course of industrial development. According to this typology, industrial activity composition goes through three stages of development. In the first stage-the "early" stage of development-there is a dominance of agriculture as well as household and craftwork activities (MIEs) in the industrial sector and this accounts for a high share of employment. In this stage, there are limited numbers of large-sized companies (usually foreign and state companies), where the bulk consists of MIEs.

The next stage is specific to countries with more development and a higher GDP per capita. SMEs are born and grow at a high rate replacing the MIEs in the manufacturing process. The reason behind this is explained as the essence of increasing the cash pool available on the market fostering the expansion of SMEs. The growth of urbanization gives a boost to the replacement of MIEs by specialized employer-entrepreneurs in a forming small-scale production base (Steel, 1979).

This is followed by the third stage, which is labeled as the "later" stage in development. It is then that large-sized manufacturing companies take dominance by replacing SMEs in some fields.

Over time, this "traditional" approach to SME development leads to the exhaustion of privileges for SMEs and large-sized enterprises achieve 
dominance (Hoselitz, 1959; Anderson, 1982). These authors have said that economic development affects the growth of GDP per capita and SMEs' share in the GDP negatively. This engenders the first of the research questions mentioned above that looks to see if SME growth reflects the level of GDP per capita.

\section{2. "Contemporary" Paradigm}

The term "flexible specialization" found its way into research in the 1980s. It is defined as the emergence of new problems that are the consequence of new rules governing production, which changed through globalization and industrial decomposition. Meanwhile, some authors are of the opinion that global manufacturing has undergone a transition from mass production (Fordist) to non-mass production (non-Fordist). By the introduction of the "flexible specialization" concept, Piore and Sabel (1984) mean the redevelopment of craft-based areas in some parts of Western Europe. SMEs in these areas have become the dominant industrial units through highly- and multi-skilled employees with "flexible" equipment embedded in the latest technology. This paradigm assumes that SMEs can grow faster than large enterprises in product or industry development. For instance, many SMEs involved in electronics and machinery are found to be more innovative and efficient than large enterprises in developed economies (Brixiova, 2013).

\subsection{Government SME Support Policy}

One of the features of SMEs is that they improve private entrepreneurship and competition in the market and this is behind the "pro-SME" ideology of government policy. Support for SMEs should enhance competition and entrepreneurship in specific countries. This support proposes positive state expenditures that will have a positive impact on SME development. The effect can be direct-state-subsidized credit lines and skill training for SMEs, for example. It can also be indirect support in the form of infrastructure and public services. The second question of this paper considers if government support is essential for SME growth (Bradley and Klein, 2016; Vivarelli, 2013). 


\section{Methodology}

\subsection{Sample and Source of Data}

The author of this article has undertaken extensive data collection on the SME sector in Uzbekistan from a number of academic publications including Uzbekistan in their scope. These materials cover mostly general data on the topic and it is not arranged in an annual sequence. In addition, the study used data available in yearbooks of the Statistics Committee of Uzbekistan and panel data provided by Statistical Committee of Uzbekistan to the author for the analysis of SME growth. The author also incorporated publications of the Center for Economic Research (a department of the Ministry of Economics of Uzbekistan). The author has also provided general figures related to the development the SME sector. The economic statistics were acquired from open source databases of the World Bank and the Asian Development Bank. As the SME sector and entrepreneurship in Uzbekistan are highlighted in only in a few articles, the author of this paper decided to devote the first two chapters to the emergence of the SME sector from the early years of independence of Uzbekistan up to recent years. These two chapters make a certain contribution for further research as they consolidate general and specific census data related to the SME sector and entrepreneurship in Uzbekistan from various sources.

\subsection{Variables}

In order to analyze the relationship between growth of the SME sector, GDP per capita, and government development expenditure, the SME sector's share in GDP, GDP per capita, and the ratio of state development expenditures was used. The dependent variable considered was SME share in GDP and the independent variables were GDP per capita and the ratio of state expenditure into development.

\subsection{Data Analysis}

The share of the SME sector in GDP is given in Figure No. 3 for the 20002010 period. The related figures for the next four years can be found in Table No. 4. Statistical data on GDP per capita, along with GDP and state development expenditure data are provided in Table No. 3 and Table No. 5. The ratio of government development expenses to GDP is the outcome of 
their division. The author used multiple linear regression with one dependent variable and two independent variables. Furthermore, R-squared was calculated for the coefficient of determination and Durbin-Watson statistics were run to find autocorrelation in the residuals.

\subsection{Limitations}

The current study covers the period from 2000 to 2014. The reason is the lack of census data on state development expenditures in statistical yearbooks up to 2000 and a rejection by the Statistics Committee of Uzbekistan of a request to provide such data for this research. Moreover, some control variables mentioned in the "contemporary" paradigm that can affect SME performance, such as the proportion of research and development expenditure in total sales or highly-qualified employees are not included in this model. The author's request for these datasets was not met by Statistical Committee of Uzbekistan, as they did not collect such panel data. Availability of census data would have to be provided for any extensive study of this topic with respect to early transition and economic stages of Uzbekistan and their comparison with the late stages. In addition, other aspects mentioned in the "contemporary" paradigm (e.g., highly-qualified employees and the R\&D expense ratio in total sales) would contribute to the model's completeness.

\subsection{Results}

The descriptive statistics and correlation matrix for variables can be found in Table No. 6. From the correlation matrix it can be seen that the correlation of SME shares in GDP (SME-GDP) and GDP per capita (GDP p.c.) is almost a perfect uphill (positive) linear relation. Subsequently, SME-GDP and the ratio of government support for development to GDP (G/GDP) have a strong downhill (negative) linear relation. The same relation between GDP p.c. and G/GDP is strongly negative. The perfect positive correlation between SME-GDP and GDP p.c. shows the perfect uphill relation. This is a response to the first research question of this paper: There is a relationship. However, the strongly negative correlation of G/GDP and SME-GDP can serve as an answer to the second research question as to the presence of any relation between Uzbek government spending for development and SME share growth in GDP. 
Table No. 6. Descriptive statistics and correlation

\begin{tabular}{|c|c|c|c|c|c|}
\hline \multirow{2}{*}{ No } & & \multirow{2}{*}{ Mean } & \multirow{2}{*}{ Std. Deviation } & \multicolumn{2}{|c|}{ Correlation } \\
\hline & & & & 2 & 3 \\
\hline 1 & SME-GDP & 44.4867 & 9.15992 & 0.972 & $(0.713)$ \\
\hline 2 & GDP p.c. & 3508.6667 & 1303.32469 & & $(0.659)$ \\
\hline 3 & G/GDP & 13.2933 & 9.59486 & & \\
\hline
\end{tabular}

Source: Based on calculations by the author using SPSS software

\subsection{Discussion}

The above results provide the answers to the questions put in this paper. Considering the survival of SMEs over the given period, the outcomes reject the "traditional" paradigm that assumes SMEs will disappear over the period of economic development as long as the GDP per capita increases. This finds justification in the figure given for recent SME sector inputs into the economy, where it is seen that Uzbek SMEs are present at a low level in total export (25.9\% in 2014) and imports (45\% in 2014) and that they mostly focus on the local market. They compete with large enterprises with their flexibility in production and innovation, and concentrate on niche markets and customization. Although the GDP per capita is increasing marginally in Uzbekistan, it is still much lower than in developed and emerging economies. Therefore, the market for budget and cheap products is dominant. This makes it beneficial for local SMEs to compete with imported goods on price. Table No. 7 shows that GDP p.c. regression coefficient for SMEGDP is a positive, while SME-GDP and G/GDP provide a negative figure. This is another proof of the result discussed from descriptive statistics. Two independent variables are significant at 9.5\% (for the one-tail test).

The outcome of the regression test as depicted in Table No. 7 shows that growth in GDP per capita and the SME sector's share in GDP in Uzbekistan are interrelated. This can be a response to the first research question of this article. A correlation between growth in GDP per capita and SME sector share in GDP can be related to the statement by Bradley and Klein (2016) that developing countries demonstrate an increase in entrepreneurial activity. They consider it as an important step in decreasing poverty in the economy. At the same time, state development expenses and growth in the share of the SME sector are not correlated. As Bradley and Klein, (2016) mentioned, entrepreneurship, along with the other forms of economic activity, operates inside an institutional context and is affected by the "rules of the gam 
Table No. 7. Generalized least square regression of SME growth (2000-2014)

\begin{tabular}{|l|rrr|}
\hline \multicolumn{1}{|c|}{ Independent variables } & \multicolumn{3}{c|}{ SME-GDP } \\
\hline Intercept & 24.229 & $2.2862^{\mathrm{a}}$ & $8.466^{\mathrm{b}}$ \\
\hline GDP p.c. & 0.006 & $0.001^{\mathrm{a}}$ & $10.859^{\mathrm{b}}$ \\
\hline G/GDP & $(0.123)$ & $0.078^{\mathrm{a}}$ & $(1.572)^{\mathrm{b}}$ \\
\hline Observation & & & \\
\hline R-squared: 0.955 & & & \\
\hline Durbin-Watson statistic: 0.443 & & & \\
\hline F-statistic: 126.197 & & & \\
\hline
\end{tabular}

a Std. error

${ }^{b}$ t statistic

Source: Based on calculations by the author using SPSS software

the SME sector are not correlated. As Bradley and Klein, (2016) mentioned, entrepreneurship, along with the other forms of economic activity, operates inside an institutional context and is affected by the "rules of the gamMoreover, legal, political, social, and economic factors in society shape the economic performance of companies. State intervention, based on publicinterest theories of regulations, can occur for the purpose of correction or regulation of market conditions (i.e. monopoly), pricing of first necessity goods, and safety and health issues as well as in general for the benefit of public welfare. On the other hand, state intervention can be backed by the private-interest theories in which state intervention takes place for the protection of domestic producers by increasing import tax on certain goods or services (Bradley and Klein, 2016). In case of Uzbekistan, one can observe the role of the state as regulator, imposing regulation and coordination to a transitional market. Although, there is no exact data on state expenditure on the SME sector support program in Uzbekistan, a negative regression coefficient for SME-GDP and G/GDP can clearly indicate that the SME sector does not have the financial support or intervention by the part of the state.

\section{Conclusion}

This research paper has managed to make a contribution to academic literature in the English language with its consolidated census data on entrepreneurship and the SME sector in Uzbekistan since independence. Moreover, 
a step-by-step analysis of reforms related to the private business sector can be used for further research into Uzbekistan in the same context or to make a comparison with other developing economies. Although most of previous research papers have researched entrepreneurship in Uzbekistan from the transitional aspect, this paper provides coverage of the transitional period. However, its primary focus was on the economic development aspect of Uzbekistan. At the same time, this paper has to be considered as a contribution to management science in the field of entrepreneurship in a developing and transitional economical context. In addition, it makes an input on the impact of public policy on entrepreneurship.

In spite of the fact that limitations exist regarding this study, the empirical findings do come up with outcomes for the research questions of the article. The summary of empirical findings shows that SME development is proceeding along the lines of the "contemporary" paradigm in which SMEs are competing with large enterprises on the market and exceeding them in some sectors. Furthermore, the term "flexible specialization" can be referred to Uzbek SMEs that are operating in a transitional and developing economic environment, where they have to adapt to changes and shift to new markets quickly in order to survive. This term can be related to the outcome of the first research question, that growth in the SME sector's share in the GDP and GDP per capita has a positive correlation. People may also have "flexible specialization" by shifting from the state sector to the private one to establish their own business. Moreover, an improvement in the welfare and growth in the net income of the population might be one of the factors behind the increase in the private business sector. Finally, the real income of SMEs is increasing and their stakeholders' real income reflects this.

The outcome regarding the second research question is that state development spending does not have any relation to the growth of SME sector share in the GDP. This shows that entrepreneurship is in the interest of the public and a part of its culture as well as that the state's role is limited mainly to being mostly a regulator and policymaker. As Bradley and Klein (2016) stated, some developed European countries with solid policies on private business are still making an effort to foster entrepreneurship for economic growth through pushing an entrepreneurial culture.

\section{References}

ADB. (2005). Private Sector Assessment for Uzbekistan. Retrieved from: http://www.adb.org/ sites/default/files/institutional-document/32223/uzb-psa.pdf (15.11.2015).

ADB. (2016). Statistical Database System: Uzbekistan. Retrieved from: https://sdbs.adb.org/ $\underline{\text { sdbs/ }}$ (25.06.2016). 
ADB. (2012). Sector Assessment (Summary): Micro, Small and Medium-Sized Enterprise Development. Small Business and Entrepreneurship Development Project. Retrieved from: http:// www.adb.org/sites/default/files/linked-documents/42007-014-ssa.pdf (15.11.2015).

Aidis, R. (2006). Laws and Customs: Entrepreneurship, Institutions and Gender During Transition. SSEES Occasional Series. London: University College London.

Anderson, D. (1982). Small Industry in Developing Countries: A Discussion of Issues. World Development, 10(11), 913-948.

Baumol, J. (2004). Entrepreneurial Enterprises, Large Established Firms and Other Components of the Free-Market Growth Machine. Small Business Economics, 23(1), 9-21, http:// dx.doi.org/10.1023/B: SBEJ.0000026057.47641.a6.

Bradley, S.W. and Klein, P. (2016). Institutions, Economic Freedom, and Entrepreneurship: The Contribution of Management Scholarship. The Academy of Management Perspectives, 30(3), 211-221.

Brixiova, Z. (2013). Modeling Productive Entrepreneurship in Developing Countries. Small Business Economics, 41(1), 183-194.

Bruton, G.D., Ahlstrom, D., and Obloj, K. (2008). Entrepreneurship in Emerging Economies: Where Are We Today and Where Should the Research Go in the Future. Entrepreneurship Theory and Practice, 32(1), 1-14.

Burke, P. (Ed.). (1979). The New Cambridge Modern History: Volume 13, Companion Volume (Vol. 13). Cambridge University Press.

CER. (2011). Альманах Узбекистан 2011. Tashkent. Centre for Economic Research.

CER. (2013). Альманах Узбекистан 2013. Tashkent. Centre for Economic Research, 155.

Elo, M. (2016). Typology of Diaspora Entrepreneurship: Case Studies in Uzbekistan. Journal of International Entrepreneurship, 14(1). Springer US, http://dx.doi.org/10.1007/s10843016-0177-9.

Eshee, W., Mardonov, I., Liddell, P., and Lidell, J. G. (2002). Entrepreneurship in The Republic of Uzbekistan: A Model for Other Emerging Nations. International Business \& Economic Research Journal, 2(11), 71-80, http://dx.doi.org/10.19030/iber.v2i11.3861.

Estrin, S., Meyer, K., and Bytchkova, M. (2005). Entrepreneurship in transition economies. In: Casson, M.C. et al. (Eds.), The Oxford Handbook of Entrepreneurship, 24, (pp. 1-47). Oxford: Oxford University Press, http://doi.org/10.1093/oxfordhb/9780199546992.003. 0027.

Finnie, J., Staley, E., and Morse, R. (1966). Modern Small Industry for Developing Countries. McGraw-Hill Series in International Development.

Gibb, A. (1995). Entrepreneurship in Transition Economies: Back to the Future. Economic Reform Today, (3).

Hoselitz, B.F. (1959). Small Industry in Underdeveloped Countries. The Journal of Economic History, 19(04), 600-618.

Hubner, W. (2000). SME Development in Countries of Central Asia (Kazakhstan, Kyrgyzstan, and Uzbekistan): Constraints, Cultural Aspects and Role of International Assistance. United Nations Industrial Development Organization. Retrieved from: https://www.unido. org/fileadmin/import/userfiles/puffk/huebner.pdf (10.10.2015).

Kan, V. (2010). Regional Determinants of New Firm Formation in a Transition Economy: The Case of Uzbekistan. Hitotsubashi University. Retrieved from: http://cis.ier.hit-u.ac.jp/ Common/pdf/dp/2010/dp490.pdf (12.10.2015).

Kan, V. (2015). Do Initial Conditions Matter? A Comparative Analysis of SME Development in Russia, Kazakhstan and Russia. CIS Discussion paper series (639), Hitotsubashi 
University. Retrieved from: http://hermes-ir.lib.hit-u.ac.jp/rs/bitstream/10086/27061/1/ DP639.pdf (10.11.2015).

Khalmurzaev, N.A. (2000). Small and Medium-Sized Enterprises in the Transition Economy of Uzbekistan: Conditions and Perspectives. Central Asian Survey, 19(2), 281-296. http:// doi.org/10.1080/02634930050079363.

Lex Uz. (2003). Об Утверждении Классификации Предприятий И Организаций, Относящихся К Субъектам Малого Предпринимательства (Бизнеса). Retrieved from: http://www.lex.uz/pages/getpage.aspx?lact_id=246536 (15.06.2015).

Lex Uz. (2014). O Внесении Изменений В Классификацию Предприятий И Организаций, Относящихся К Субъектам Малого Предпринимательства (Бизнеса). Retrieved from: http://lex.uz/pages/getpage.aspx?lact_id=2420423 (15.06.2015).

Majidov, T. (2007). Entrepreneurship and Business in Uzbekistan: Historical Perspective and Current Obstacles. Doctoral dissertation. Stirling: University of Stirling.

McIntyre, R. (2001). The Role of Small and Medium Enterprises in Transition: Growth and Entrepreneurship. Research for Action (49). UNU/WIDER. pp. 1-63 Retrieved from: https://www.wider.unu.edu/sites/default/files/rfa49.pdf (15.06.2016).

Nikolova, E. and Simroth, D. (2013). Does Cultural Diversity Help or Hinder Entrepreneurs? Evidence from Eastern Europe and Central Asia. EBRD, (158), 1-42. Retrieved from: http://www.ebrd.com/downloads/research/economics/workingpapers/wp0158.pdf (15.11.2015)

Piore, M.J. and Sabel, C.F. (1981). Italian Small Business Development Lessons for US Industrial Policy. Working papers from Massachusetts Institute of Technology (MIT), No. 288, Department of Economics.

Pomfret, R. (2000). Agrarian Reform in Uzbekistan: Why Has the Chinese Model Failed to Deliver? Economic Development and Cultural Change, 48(2), 269-284, http://dx.doi. org/10.1086/452458.

Reynolds, P.D. (2007). New Firm Creation in the United States: A PSED I Overview. Hanover, Massachusetts: Now Publishers, Inc.

Salayev, S.K. (2008). Кичик Бизнес Ривожланиш Тенденцияларини Моделлаштириш Ва Башоратлаш. Tashkent. Tashkent State University of Economics. Retrieved from: www. ziyonet.uz/uploads/books/49959/53ccbd2d7aaf2.doc (18.12.2015).

Smallbone, D. (1996). Supporting SMEs Development in Economies in Transition: A View from the West. In: M. Dimitrov, K. Todorov, (Eds.), Industrial Organization and Entrepreneurship in Transition (pp. 316). Sofia: Informa Intellect.

Smallbone, D. and Welter, F. (2001). The Distinctiveness of Entrepreneurship in Transition Economies. Small Business Economics, 16(4), 249-262, http://doi.dx.org/10.1023/ A:1011159216578.

Smallbone, D. and Welter, F. (2010). Entrepreneurship and the Role of Government in PostSocialist Economies: Some Institutional Challenges. Historical Social Research, 35(2), 320-333. http://doi.dx.org/10.2307/20762462.

State Statistics Committee. (2015). Узбекистан в Цифрах 2015. Statistical Collection. Tashkent.

State Statistics Committee of Uzbekistan. (2015a). Малое Предпринимательство Узбекистана. Tashkent.

State Statistics Committee of Uzbekistan. (2015b). Статистический Ежегодник. Tashkent. Steel, W.F. (1979). Development of the Urban Artisanal Sector in Ghana and Cameroun. The Journal of Modern African Studies, 17(02), 271-284. 
Svejnar, J. (1991). Microeconomic Issues in the Transition to a Market Economy. Journal of Economic Perspectives, 5(4), 123-138. Retrieved from: http://pubs.aeaweb.org/doi/ pdfplus/10.1257/jep.5.4.123 (10.06.2016).

UN. (1999). The Development of Entrepreneurship and Small Business in Transitional Economies. New York, New York. Retrieved from: https://publicadministration.un.org/ publications/content/PDFs/E-Library\%20Archives/1999\%20Development $\% 20$ of\%20 Entrepreneurship\%20and\%20Small\%20Business\%20in\%20Transitional\%20Economies. pdf (15.06.2016).

World Bank. (2016). World Development Indicators: Uzbekistan. Retrieved from: http://databank.worldbank.org/data/reports.aspx? source=2\&country=UZB (25.06.2016).

Vivarelli, M. (2013). Is Entrepreneurship Necessarily Good? Microeconomic Evidence from Developed and Developing Countries. Industrial and Corporate Change, 22(6), 1453-1495.

Zahra, S.A., Wright, M., and Abdelgawad, S.G. (2014). Contextualization and the Advancement of Entrepreneurship Research. International Small Business Journal, 32(5), 479-500. 


\section{Sabina Grižančič̌}

\section{Launch Strategy in Crowdfunded NVTs: Exploring Storytelling}

According to certain authors, new venture success or failure depends mostly on the strategic initiatives taken by the team (Gilbert, McDougall, and Audretsch, 2006). Due to a lack of resources, environmental uncertainty, and different perceptions on the part of team members, strategic choices and initiatives are complex issues for new venture teams (Ensley, Pearce, and Hmieleski, 2006; DeTienne, McKelvie, and Chandler, 2015). Therefore, there is a compelling need to research and explore how new venture teams make strategic choices through which they pursue and attain success (Gilbert et al., 2006; Kor, Mahoney, and Michael, 2007).

In recent years, an increasing number of strategy researchers began to consider storytelling as a relevant strategic practice and an essential component of an entrepreneur's toolkit for external resource acquisitions (Martens et al., 2007; De la Ville and Mounoud, 2010; Sonenshein, 2010). New venture teams on crowdfunding platforms, more than any other fundraisers, use stories to attract backers. Storytelling has simultaneously become their weapon to attract capital as well as their portfolio and product launch strategy. This paper provides a theoretical background for future research into the phenomena of storytelling and narratives in reward-based crowdfunded new venture teams.

Keywords: entrepreneurship, crowdfunding, new venture team, launch strategy, storytelling.

\section{Strategie startu w przypadku zespołów ds. nowych przedsięwzięć finansowanych społecznościowo - storytelling jako temat badań}

Według niektórych autorów, sukces lub klęska nowych przedsięwzięć zależą głównie od strategicznych inicjatyw podjętych przez zespół (Gilbert, McDougall i Audretsch, 2006). Ze względu na brak zasobów, niepewności środowiska oraz różne poglądy członków zespołu, strategiczne decyzje i inicjatywy to sprawy skomplikowane, szczególnie w przypadku zespołów ds. nowych przedsięwzięć (Ensley, Pearce i Hmieleski, 2006; DeTienne, McKelvie i Chandler, 2015). Dlatego też wydaje się, że istnieje nieodparta potrzeba badania i eksploracji w jaki sposób zespoły ds. nowych przedsięwzięć podejmują decyzje strategiczne, a następnie je realizują i osiągają sukces (Gilbert et al., 2006; Kor, Mahoney i Michael, 2007). Rosnąca ostatnio liczba badaczy strategii zaczęła przyglądać się storytelling jako istotnej

* Sabina Grižančič, Ph.D. Candidate - e-mail: sabinagrizancic@gmail.com. 
praktyce strategicznej, a jednocześnie niezbędnemu składnikowi zestawu narzędzi przedsiębiorcy by przyciągnąć zewnętrzne zasoby (Martens et al., 2007; De la Ville i Mounoud, 2010; Sonenshein, 2010). Zespoły ds. nowych przedsięwzięć na platformach finansowania społecznościowego wykorzystują storytelling i bardziej niż inni starają się o wsparcie. Jednocześnie stało się ono ich bronią w przyciągania kapitału, jak również portfelem i strategią przy wypuszczeniu produktu.

Artykuł zapewnia teoretyczne tło do przyszłych badań fenomenu storytelling oraz narracji w zespołach ds. nowych przedsięwzięć opartych na nagrodach.

Słowa kluczowe: przedsiębiorczość, finansowanie społecznościowe, zespoły ds. nowego przedsięwzięcia, strategia startu, storytelling.

JEL: G21, G24, L26, M13

\section{Introduction}

Limited revenue and high start-up costs force new ventures to seek external funding. Obtaining a sufficient amount of capital not only enables entrepreneurs and NVTs to develop their ideas and follow opportunities, but also facilitates their survival, growth, and profit gain. Raising funds is a complex and challenging task for all new ventures. The origin of the challenge is in information asymmetry: Resource providers possess less information than entrepreneurs about certain opportunities and their proposed means of exploiting it (Martens, Jennings, and Jennings, 2007). This is what is known as the "principal-agent problem," which is one of the basic dilemmas in economics and political science.

Principal-agent relationships occur when principals (shareholders) hire agents (managers) to perform a service on the principal's behalf (Arthurs and Busenitz, 2003). The most important agency relationship in finance is the relationship between stockholders and managers. There are two main problems in this relationship. The first problem occurs when the desires or goals of the principal and agent are in conflict and the principal is unable to verify what the agent is actually doing. The agent who is supposed to make decisions that best serve the principal is naturally motivated by self-interest, which may differ from the principal's interests (Truong and Heaney, 2013). The second problem arises when the principal and agent have different attitudes with respect to risk, where each may be inclined to take different action (Arthurs and Busenitz, 2003).

In recent years, an increasing number of NVTs rely on a relatively cheap and easy way of raising capital from a large number of people in small amounts-crowdfunding. This novel, semi-formalized mechanism for financing new ventures (Frydrych and Kinder, 2015), which has a few 
variations, reshaped the classic principal-agent relationship, especially in reward-based crowdfunding. In reward-based crowdfunding the financial motives for supporting fundraisers are weak. The principal is not concerned with maximizing economic wealth, but simply wants goods or a service in return for the investment. The agent, on the other hand, is seeking to maximize economic wealth. This reduction of common ground leads to agency loss and impacts on the relationship between both parties negatively.

In this research, we are going to investigate the principal-agent relationship. We will review storytelling as an aspect of launch strategy used by NVTs to attract supporters and seek funds on reward-based crowdfunding platforms, in addition to attempting to reduce the principal-agent problem. We will focus on reward-based crowdfunding, as we believe this is the platform where storytelling is most prominent.

\section{Launch Strategy in Crowdfunded NVTs}

\subsection{Launch Strategy}

Although previous research has investigated the concept and contents of new product performance and product launch strategy, there is still no consensus as to how a launch strategy is selected and formulated in SMEs. While extensive research has been conducted on other success differentiators, few studies have investigated the anatomy, the formulation, and selection of a new product launch strategy closely.

Product launch is often the most expensive, risky, and least well-managed part of the overall product development process (Montoya-Weiss and Calantone, 1994). Identifying target markets, establishing marketing roles, forecasting financial outcomes, and controlling the project (Hultink and Robben, 1999) are only some of the activities that an effective product launch must include. Therefore, it is not surprising that an effective new product launch greatly improves the overall chances of product success (Calantone and Di Benedetto, 1988).

Literature identifies two broad categories of launch decisions: strategic and tactical. Strategic decisions are those concerning the product and markets, such as how innovative the product should be, which market the product should be launched onto, and what the competitive advantages are. Strategic decisions are often finalized early in the new product development process. Strategic decisions are target market decisions (niche versus mass market), leader versus follower decisions, and decisions on relative inno- 
vativeness (Montoya-Weiss and Calantone, 1994; Guiltinan, 1999). Tactical decisions include marketing mix decisions such as product branding, promotion activities, pricing decisions, sales and distribution support, and timing decisions. These decisions are usually made after the strategy has been chosen, and may be influenced by other strategic decisions (Montoya-Weiss and Calantone, 1994). Tactical decisions are easily modified in later stages of the new product development process.

The primary objective of launch strategy is to stimulate demand; to a certain extent, we logically expect that the selection of launch activities and decisions depend on the type of buying behavior to be influenced. Conventional product launch strategies are often inadequate and not flexible enough for the highly competitive environment of crowdfunding platforms. Furthermore, crowdfunded NVTs do not have the intellectual or financial resources to use traditional strategies.

\subsection{Crowdfunding}

According to the 2015 Crowdfunding Industry Report (Market Wired, 2015), crowdfunding platforms worldwide raised US\$ 1.6 billion in 2014 and the estimated amount of funds collected in 2015 rose to US\$ 34 billion. The dynamic of crowdfunding remains largely unstudied (Mollick, 2014). This is in spite of the fact that entrepreneurship literature provides evidence that crowdfunding matters at the level of individuals, networks, and teams (Bruton, Khavul, Siegel, and Wright, 2015).

The determinants and consequences of crowdfunding are new and so are the influences that crowdfunding has on new ventures and NVTs (Cope, 2011; Ahlers, Cumming, Günther, and Schweizer, 2015). Nevertheless, the concept of mobilizing funds in small pieces from many individuals is older than crowdfunding platforms and can be found in many economies going back as far as the 18th century when the model was used to finance the printing of books (Zademach and Baumeister, 2013; Turan, 2015). With the demands and communication technologies of the 21st century (Antonenko, Lee, and Kleinheksel, 2014), the idea of pooling funds from the crowd (Ordanini, Miceli, Pizzetti, and Parasuraman, 2011) was completely revolutionized and took on an inconceivable dimension. David Drake (Drake, 2016), chairman of LDJ Capital, estimates that the number of crowdfunding platforms increased to over 2,000 in 2016. An impressive number if we compare it with the 700 crowdfunding platforms from 2012.

The concept of crowdfunding originated from crowdsourcing, a broader concept, which refers to using the crowd to obtain ideas, feedback, 
and solutions to develop corporate activities (Belleflamme, Lambert, and Schwienbacher, 2014; Bayus, 2013; Kleemann, Voß, and Rieder, 2008). Crowdfunding diffused from an initial launch in several developed economies immediately after the global financial crisis of 2007-2008, when traditional financing for small ventures dried up. Crowdfunding, or the collective, community-driven financing of projects, has attracted creative individuals from around the world since 2009 when the first crowdfunding platform, Kickstarter, was launched. Crowdfunding immediately became an increasingly popular means of raising money for both personal and creative ventures, particularly in the early stages of business, when capital is most needed but most difficult to get (World Bank, 2013). One reason for its popularity is in the relatively cheap and easy way of raising money from a large number of people in small amounts with web technology and existing online payment systems (Gerber, Hui, and Kuo, 2011; Rossi, 2014). A group of people, the crowd, financially contributes small amounts to projects, products, or ideas. These projects, products, or ideas are owned by fundraisers seeking money via a specific digital platform (intermediary), in order to get their project realized (Bouncken, Komorek, and Kraus, 2015).

Crowdfunding allows initiatives to gather financial resources from a large pool of small-scale investors rather than a very small group of sophisticated ones (Riedl, 2013; Belleflamme, Omrani, and Peitz, 2015). Accordingly, these projects differ in terms of requested investment amount and kind of compensation promised to investors (Cordova, Dolci, and Gianfrate, 2015). Since the establishment of the first crowdfunding platform, different forms of crowdfunding, ranging from an equity-based model, profit-sharing scheme, and lending, to outright donations, has emerged. There are two main types of crowdfunding: reward crowdfunding and equity crowdfunding. Reward-based platforms typically provide something in return for the money provided: the first versions or exclusive limited editions of the product or service being funded (Belleflamme, Lambert, and Schwienbacher, 2014). Equity-based platforms instead provide backers with shares of a company in exchange for the money pledged. An additional type is debt crowdfunding, the funding of debt from individuals and other organizations, which has grown rapidly and has moved into its own category, known as peerto-peer lending (Defining Marketplace Landing, Peer-to-Peer Lending, and Crowdfunding, 2016). 


\subsection{Reward-Based Crowdfunding}

Despite some differences, most reward-based crowdfunding sites provide the same basic functionality. First, the fundraiser sets up a webpage for the campaign and posts a description of the campaign asking for contributions from their community to support the project or a phase of the project. When clicking on a project name, the potential supporter is taken to a page containing a description of that project. Usually, the description consists of a video, supporting text, and images illustrating the concept (Antonenko et al., 2014). The entrepreneur is usually given a certain amount of time to reach the campaign goal and, if this goal is reached, the campaign is successful. The other immediately available information is the real-time amount of capital raised, the percent of target capital raised, the number of people who have pledged, and how many days remain before the closure of the campaign (Colombo, Franzoni, and Rossi-Lamastra, 2015). What is employed is a reward-based model, meaning that backers pledge money in exchange for a reward chosen from various rewards offered by a project's proponents. There may be different types of rewards, ranging from a finished product or a gadget to participation in an event. Rewards cannot be a share of profits, an interest rate, or anything else that might configure the transaction as involving an offer of equity or a loan.

Crowdfunding is almost synonymous for Kickstarter, the world's biggest and most recognized reward-based crowdfunding platform, situated in the United States and operated worldwide. Kickstarter hosts crowdfunding campaigns from fifteen different categories: music, film and video, publishing, art, games, design, theatre, food, technology, comics, fashion, photography, dance, crafts, and journalism (Kickstarter Stats, 2017). The second most common household name in reward-based crowdfunding is Indiegogo, also a United States based platform. Indiegogo hosts campaigns in twenty-four categories: animal, art, comics, community, dance, design, education, environment, fashion, film, food, gaming, health, music, photography, politics, religion, small business, sports, technology, theater, transmedia, video/web, and writing (Indiegogo, 2017). There are a few differences between these two giants. However, we will only mention those that, in our opinion, may influence their effort to tell the right stories: funding scheme, project registration, and backer information.

Kickstarter applies an "all-or-nothing" model where the money pledged to a project is cashed only if by the day a campaign closes, the money pledged to a project is equal to or greater than the target amount. Otherwise, the campaign is unsuccessful and all pledges are voided (Bayus, 2013; Kuppuswamy and Bayus, 2015; Mollick, 2014). While Indiegogo does provide the all or 
nothing option, you can also choose to take the funding, regardless the success of the campaign. Kickstarter has stricter requirements for registration. Their three major rules are no personal fundraising projects, no charity, and no working prototypes. If you do not yet have a working prototype, you will have to hold off on your Kickstarter project. Indiegogo is far less strict. Kickstarter allows campaigns from eighteen different countries, compared to Indiegogo, which hosts campaigns from around the world (224 countries). Indiegogo provides contact information for backers the moment they hit the pay button. In contrast, Kickstarter projects need to wait until they reach their goal, then they need to conduct a survey and ask their backers to provide them with contact information if they want any feedback before the campaign closes.

\section{Storytelling}

The narrative is one of the most elementary aspects of life. Stories are basic human ways of organizing episodes, actions, and accounts of actions (Cunliffe, Luhmann, and Boje, 2004) and since prehistoric times people have been attracted by stories and make sense of them (Fisher, 1985; Monarth, 2014). From the perspective of hermeneutic phenomenology, stories work as a form of narrating, where narrating involves a narrator, an audience, a subject, and an arrangement of elements, including events, situations, experiences, and characters (Cunliffe et al., 2004).

There has not been much empirical research examining the relationship between entrepreneurial storytelling and external resource acquisition, although more and more researchers emphasize the importance of the topic. Below, some relevant studies dealing with storytelling in different environments are presented, but none of them in reward-based crowdfunding. However, those studies make a good starting point for analyzing storytelling and storytelling elements in reward-based crowdfunding.

\subsection{Entrepreneurial Narratives in Resource Acquisition}

One of the first studies integrating narratives and resource acquisition was made in 2007. Martens, Jennings, and Jennings (2007) integrated theory and research on the resource acquisition process. They developed and tested three arguments about how narratives (stories) help entrepreneurs attract capital in initial public offering prospectuses-they help potential resource 
providers comprehend an entrepreneurial firm's identity by packaging factual information about its stock of tangible and intangible capital into a simpler, more coherent and meaningful whole; stories help prospective investors understand the nature and potential value of a firm's proposed means of exploiting entrepreneurial opportunities by elaborating the reasoning behind its intended strategic initiatives; stories help generate interest and commitment among potential resource providers by connecting to broader contextual narratives in such a way so that the proposed endeavor appears original and distinctive. They found out that these arguments, combined in an effective story, not only reduce the perceived uncertainty and risk associated with the exploitation of entrepreneurial opportunities (Pollock and Rindova, 2003; Cohen and Dean, 2005), but also motivate and mobilize potential resource providers into committing capital to an entrepreneurial enterprise.

\subsection{Impression Management and the Role of Language}

Impression management is a conscious and subconscious process in which individuals present themselves and try to influence the perceptions of other people by regulating and controlling information in social interaction (Parhankangas and Ehrlich, 2014; Gleasure, 2015). Impression management tactics seem to be particularly relevant in situations in which entrepreneurs try to convince a powerful audience, as is the case on crowdfunding platforms.

Crowd investors might, unlike traditional financiers, have less knowledge about the specific field of industry. Therefore, they might be more easily convinced through the storytelling of entrepreneurs (Parhankangas and Renko, 2017). Furthermore, crowdfunding allows individuals to fund business projects directly. On the other hand, crowdfunding allows entrepreneurs to control the impression they make on the crowd. Impression management can have a significant effect on the outcome of a crowdfunding campaign by using specific language (Lins, Fietkiewicz, and Lutz, 2016). In their analysis, Lins, Fietkiewicz, and Lutz (2016) demonstrate that the use of positive language patterns has a positive effect on the likelihood of raising the targeted amount. The tactics where the use of well-chosen language is essential are self-promotion, supplication, exemplification, ingratiation, and intimidation.

\subsection{Causing Desire and Freytag's Pyramid}

Paul J. Zak (2014), an American neuroeconomist, discovered that in order to motivate a desire to help others, a story must first sustain attention. If the 
narrative is able to develop tension, our brain releases oxytocin. Oxytocin is a neurochemical that is produced in the brain when we are trusted or shown a kindness. The release of chemical oxytocin promotes connection and empathy. Therefore, we are motivated to cooperate with others and are more willing to support different campaigns (Zak, 2014).

The other important factor, besides generating interest, is Freytag's Pyramid (Monarth, 2014). The result of a two-year analysis of 108 Super Bowl commercials made by Quesenberry and Coolsen (2014) shows that people respond better to ads with the kind of dramatic story plots used by William Shakespeare than without it. It is essential to keep in mind the valuable information that when investors consider reward-based crowdfunding projects, it is similar to the process of customers making purchase decisions (Bi, Liu, and Usman, 2017).

Freytag's pyramid or dramatic structure is the structure of a dramatic work such as a play. Gustav Freytag was a 19th century German novelist who analyzed the dramatic structure of ancient Greek and Shakespearean dramas. He discovered common patterns in the storylines and developed a diagram to analyze them. According to Freytag, a drama is divided into five parts, or acts: exposition, rising action, climax, falling action, and dénouement (Quesenberry and Coolsen, 2014).

\section{Conclusion and Future Implications}

This study is a brief overview of the theoretical background for researching launch strategies in reward-based crowdfunded NVTs, or more exactly, storytelling. It provides partial evidence of storytelling research in other environments, such as IPO and marketing, which can be applied to crowdfunding. At this moment we have to point out that storytelling is just one of the aspects of product launch strategy. Future research can be extended to other aspects. We limited this study to storytelling, as we would like to further explore elements of storytelling in reward-based crowdfunding, by far the most popular type of crowdfunding in Slovenia.

This research represents only a drop in the ocean. Therefore, it is hard to draw any definitive conclusions. We encourage further research in two directions. Our research takes into account only some aspects of storytelling, but there are others that may influence storytelling such as trust management, which can also be translated into crowdfunding. It might be wise to review existing literature in greater depth. Secondly, our study is limited to an analysis of written documents, which restricts our mind. Therefore, 
empirical investigation would be particularly beneficial. Moreover, responding to the following questions would make it much easier: Which elements are they using in their storytelling? Are they consciously even using them? Are they aware of their actions or not? Is there any underlying strategic goal behind the story?

\section{References}

Ahlers, G.K.C., Cumming, D., Günther, C., and Schweizer, D. (2015). Signaling in Equity Crowdfunding. Entrepreneurship: Theory and Practice, 39(4), 955-980.

Antonenko, P.D., Lee, B.R., and Kleinheksel, A.J. (2014). Trends in the Crowdfunding of Educational Technology Startups. TechTrends, 58(6), 36-41.

Arthurs, J.D., and Busenitz, L.W. (2003). The Boundaries and Limitations of Agency Theory and Stewardship Theory in the Venture Capitalist/Entrepreneur Relationship. Entrepreneurship: Theory and Practice, 28(2), 145-162.

Baumeister, C. and Zademach, H.M. (2013). Financing GPNs through Inter-Firm Collaboration? Insights from the Automotive Industry in Germany and Brazil.

Bayus, B.L. (2013). Crowdsourcing New Product Ideas over Time: An Analysis of the Dell Ideastorm Community. Management Science, 59(1), 226-244.

Belleflamme, P., Lambert, T., and Schwienbacher, A. (2014). Crowdfunding: Tapping the Right Crowd. Journal of Business Venturing, 29(5), 585-609.

Belleflamme, P., Omrani, N., and Peitz, M. (2015). The Economics of Crowdfunding Platforms. Information Economics and Policy, 33, 11-28.

Bi, S., Liu, Z., and Usman, K. (2017). The Influence of Online Information on Investing Decisions of Reward-Based Crowdfunding. Journal of Business Research, 71, 10-18.

Bouncken, R.B., Komorek, M., and Kraus, S. (2015). Crowdfunding: The Current State of Research. The International Business \& Economics Research Journal (Online), 14(3), 407.

Bruton, G., Khavul, S., Siegel, D., and Wright, M. (2015). New Financial Alternatives in Seeding Entrepreneurship: Microfinance, Crowdfunding, and Peer-to-Peer Innovations. Entrepreneurship: Theory and Practice, 39(1), 9-26.

Calantone, R.J., Di Benedetto, C.A., and Meloche, M.S. (1988). Strategies of Product and Process Innovation: A Loglinear Analysis. RઐD Management, 18(1), 13-21.

Chen, X.-P., Yao X., and Kotha, S. (2009). Entrepreneur Passion and Preparedness in Business Plan Presentations: A Persuasion Analysis of Venture Capitalists' Funding Decisions. Academy of Management Journal, 52(1), 199-214.

Cohen, B.D., and Dean, T.J. (2005). Information Asymmetry and Investor Valuation of IPOs: Top Management Team Legitimacy as a Capital Market Signal. Strategic Management Journal, 26(7), 683-690.

Colombo, M.G., Franzoni, C., and Rossi-Lamastra, C. (2015). Internal Social Capital and the Attraction of Early Contributions in Crowdfunding. Entrepreneurship Theory and Practice, 39(1), 75-100.

Cope, J. (2011). Entrepreneurial Learning from Failure: An Interpretative Phenomenological Analysis. Journal of Business Venturing, 26(6), 604-623.

Cordova, A., Dolci, J., and Gianfrate, G. (2015). The Determinants of Crowdfunding Success: Evidence from Technology Projects. Procedia-Social and Behavioral Sciences, 181, 115-124. 
Cunliffe, A.L., Luhman, J.T., and Boje, D.M. (2004). Narrative Temporality: Implications for Organizational Research. Organization Studies, 25(2), 261-286.

De La Ville, V.I., and Mounoud, E. (2010). A Narrative Approach to Strategy as Practice: Strategy Making from Texts and Narratives. Cambridge Handbook of Strategy as Practice, 183-198.

Prime Meridian Capital Management. (2015). Defining Marketplace Landing, Peer-to-Peer Lending, and Crowdfunding. Retrieved from: http://www.pmifunds.com/definingmarketplace-lending-peer-peer-lending-crowdfunding/ (30.08.2016).

DeTienne, D.R., McKelvie, A., and Chandler, G.N. (2015). Making Sense of Entrepreneurial Exit Strategies: A Typology and Test. Journal of Business Venturing, 30(2), 255-272.

Drake, D. (2016, October 22). 2,000 Global Crowdfunding Sites to Choose from by 2016: Top 5 Growth Indicators. Retrieved from: http://www.huffingtonpost.com/ david-drake/2000-global-crowdfunding-_b_8365266.html (20.02.2017).

Ensley, M.D., Pearce, C.L., and Hmieleski, K.M. (2006). The Moderating Effect of Environmental Dynamism on the Relationship between Entrepreneur Leadership Behavior and New Venture Performance. Journal of Business Venturing, 21(2), 243-263.

Fisher, W.R. (1985). The narrative paradigm: In the beginning. Journal of Communication, 35(4), 74-89.

Frydrych, D., and Kinder, T. (2015). How New Is Crowdfunding? The Venture Capital Evolution without Revolution-Discourse on Risk Capital Themes and their Relevance to Poland. Problemy Zarzadzania [Management Issues], 13(56), 177-194.

Gerber, E.M., Hui, J.S., and Kuo, Y.P. (2011). Crowdfunding: Why People Are Motivated to Post and Fund Projects on Crowdfunding Platforms. Retrieved from: http://www.juliehui.org/ wp-content/uploads/2013/04/CSCW_Crowdfunding_Final.pdf (30.08.2015).

Gilbert, B.A., McDougall, P.P., and Audretsch, D.B. (2006). New Venture Growth: A Review and Extension. Journal of Management, 32(6), 926-950.

Gleasure, R. (2015). Resistance to Crowdfunding among Entrepreneurs: An Impression Management Perspective. The Journal of Strategic Information Systems, 24(4), 219-233.

Guiltinan, J.P. (1999). Launch Strategy, Launch Tactics, and Demand Outcomes. Journal of Product Innovation Management, 16(6), 509-529.

Hultink, E.J. and Robben, H.S. (1999). Launch Strategy and New Product Performance: An Empirical Examination in the Netherlands. Journal of Product Innovation Management, 16(6), 545-556.

https://go.indiegogo.com (25.02.2017).

https://www.kickstarter.com/help/stats (24.02.2017).

Kleemann, F., Voß, G.G., and Rieder, K. (2008). Un(der) Paid Innovators: The Commercial Utilization of Consumer Work through Crowdsourcing. Science, Technology \& Innovation Studies, 4(1), PP-5.

Kor, Y.Y., Mahoney, J.T., and Michael, S.C. (2007). Resources, Capabilities and Entrepreneurial Perceptions. Journal of Management Studies, 44(7), 1187-1212.

Kuppuswamy, V. and Bayus, B.L. (2015). Crowdfunding Creative Ideas: The Dynamics of Project Backers in Kickstarter. UNC Kenan-Flagler Research Paper, (2013-15).

Lins, E., Fietkiewicz, K.J., and Lutz, E. (2016, January). How to Convince the Crowd: An Impression Management Approach. In 2016 49th Hawaii International Conference on System Sciences (HICSS) (pp. 3505-3514). IEEE.

Market Wired. (2015, March 31). Retrieved from: http://www.marketwired.com/press-release/ crowdfunding-market-grows-167-2014-crowdfunding-platforms-raise-162-billion-findsresearch-2005299.htm (21.10.2015). 
Martens, M.L., Jennings, J.E., and Jennings, P.D. (2007). Do the Stories They Tell Get Them the Money They Need? The Role of Entrepreneurial Narratives in Resource Acquisition. Academy of Management Journal, 50(5), 1107-1132.

Mollick, E. (2014). The Dynamics of Crowdfunding: An Exploratory Study. Journal of Business Venturing, 29(1), 1-16.

Monarth, H. (2014). The Irresistible Power of Storytelling As a Strategic Business Tool. Harvard Business Review.

Montoya-Weiss, M.M. and Calantone, R. (1994). Determinants of New Product Performance: A Review and Meta-Analysis. Journal of Product Innovation Management, 11(5), 397-417.

Ordanini, A., Miceli, L., Pizzetti, M., and Parasuraman, A. (2011). Crowdfunding: Transforming Customers into Investors through Innovative Service Platforms. Journal of Service Management, 22(4), 443-470.

Parhankangas, A., and Ehrlich, M. (2014). How Entrepreneurs Seduce Business Angels: An Impression Management Approach. Journal of Business Venturing, 29(4), 543-564.

Parhankangas, A. and Renko, M. (2017). Linguistic Style and Crowdfunding Success Among Social and Commercial Entrepreneurs. Journal of Business Venturing.

Pollock, T.G. and Rindova, V.P. (2003). Media Legitimation Effects in the Market for Initial Public Offerings. Academy of Management Journal, 46(5), 631-642.

Quesenberry, K.A. and Coolsen, M.K. (2014). What Makes a Super Bowl Ad Super? Five-Act Dramatic Form Affects Consumer Super Bowl Advertising Ratings. Journal of Marketing Theory and Practice, 22(4), 437-454.

Riedl, J. (2013). Crowdfunding Technology Innovation. Computer, 46(3), 0100-103.

Rossi, M. (2014). The New Ways to Raise Capital: An Exploratory Study of Crowdfunding. International Journal of Financial Research, 5(2), 8-18.

Sonenshein, S. (2010). We're Changing-Or Are We? Untangling the Role of Progressive, Regressive, and Stability Narratives during Strategic Change Implementation. Academy of Management Journal, 53(3), 477-512.

Truong, T.T. and Heaney, R. (2013). The Determinants of Equity Agency Conflicts Between Managers and Shareholders: Evidence from Australia. Journal of Multinational Financial Management, 23(4), 314-326.

Turan, S.S. (2015). Financial Innovation-Crowdfunding: Friend or Foe? Procedia - Social and Behavioral Sciences, 195, 353-362.

World Bank. (2013). Crowdfunding's Potential for the Developing World. Washington, DC: World Bank. Retrieved from: http://www.infodev.org/infodev-files/wb_crowdfundingreport-v12.pdf (13.08.2015).

Zak, P. (2014). Why Your Brain Loves Good Storytelling. Harvard Business Review.

Zheng, H., Hung, J.L., Qi, Z., and Xu, B. (2016). The Role of Trust Management in RewardBased Crowdfunding. Online Information Review, 40(1), 97-118. 


\section{Economic Benefits Stemming from the Implementation of Business Process Management and Business Process Model and Notation}

Organizations are characterized by a structure that is both complicated and specific. This structure necessitates the use of bureaucratic procedures, observance of the law, and the professional preparing of employees. Many business process modeling techniques have been proposed over recent decades. Business Process Management (BPM) continues to be a top business priority, while building business process capability is still a major challenge facing senior executives (Gartner, 2009). The article shows the economic benefits resulting from the implementation of both the BPM concept and BPMN class IT systems for organizations. Action research have played a key role in preparation of the article.

Keywords: business process, BPM, workflow.

\section{Ekonomiczne korzyści wynikające z zastosowania Zarządzania Procesami Biznesowymi oraz z Notacji i Modelu Procesu Biznesowego}

Organizacje charakteryzują się strukturą, która jest jednocześnie skomplikowana i specyficzna. Wymusza ona zastosowanie biurokratycznych procedur, przestrzeganie prawa oraz fachowe przygotowanie pracowników. Przez dziesięciolecia zaproponowano już wiele technik modelowania procesów biznesowych. Zarządzanie Procesami Biznesowymi (BPM) pozostaje jednak głównym priorytetem biznesowym, a budowanie zdolności procesów biznesowych nadal jest istotnym wyzwaniem dla najwyższego szczebla kierowniczego (Gratner, 2009). Artykuł przedstawia korzyści ekonomiczne wynikające z zastosowania zarówno idei BPN, jak i systemów informatycznych klasy BPMN w organizacji. Aktywne badania odegrały kluczową rolę w sporządzeniu artykułu.

Słowa kluczowe: proces biznesowy, BPM, cykl pracy.

JEL: C32

* Małgorzata Oleś, Ph.D. Candidate - University of Warsaw, Faculty of Management, Department of Management Information Systems; Szturmowa Street 1/3, 02-678 Warsaw, Poland; e-mail: MOles@wz.uw.edu.pl. 


\section{Introduction}

Process modeling is widely used in organizations as a method for increasing awareness and knowledge of business processes as well as to deconstruct organizational complexity (Bandara, Gable, and Rosemann, 2014, pp. 347-360). It is an approach for describing how businesses conduct their operations and typically includes graphical depictions of at least the activities, events/states, and control flow logic that constitute a business process (Davenport, 2005, pp. 100-108). Additionally, process models may include information regarding the data involved, organizational/IT resources, and potentially other artifacts such as external stakeholders and performance metrics, to name just a few (Scheer, 2000).

The Business Process Model and Notation is a standard notation for capturing business processes, especially at the level of domain analysis and high-level system design (OMG, 2006). The notation inherits and combines elements from a number of previously proposed notations for business process modeling, including the XML Process Definition Language (XPDL) (WFMC, 2002) and the Activity Diagrams component of Unified Modeling Notation (UML) (OMG, 2005). Business Process Model and Notation is based on concepts of the Business Process Modeling Initiative (BPMI). Marek Piotrowski defined the business process as "a system change transforming a defined input state in a defined initial state according to specific rules" (Piotrowski, 2007, p. 136). BPMN is a stable, graphical notation that describes the steps in a business process. It is designed in such a way so as to reflect the process flow and the flow of information among processes. Interest in BPM has triggered substantial academic and commercial work aimed at advanced business process management solutions. One prominent example in this context is the increasingly popular business process modeling (Davies, 2006, pp. 358-380).

On the one hand, the popularity of BPMN is due to the fact that it consists of several elements that allow the creation of a simple model describing a business process. On the other hand, this notation has a very powerful mechanism associated with event description, which makes it possible to also present less important details using a small number of elements.

Modeled business processes describe activities related to the transformation of knowledge about the functioning of a selected area (business) model through a mapping process carried out in the organization.

The main goal of the BPMN language is to provide a notation that is readily understandable by all project participants involved in business processes. For this reason, its developers proposed a method to record business 
processes for use by business analysts and designers (who develop the preliminary process designs), programmers and computer scientists (who are responsible for the implementation of the technological platform that will be used for the processes), and business people (who will manage and monitor the implemented processes). This allows individuals, information, and themes to communicate through a common language-a significant advantage of the notation.

Over time, many organizations have built repositories of business process models that serve as a knowledge base for their ongoing business process management efforts. Such repositories may contain hundreds or even thousands of business process models. For example, a repository of Dutch local government councils contains nearly 500 process models. This is a small number compared to the size of process model repositories maintained by multinational companies. They typically contain several thousand models (2006, pp. 249-254).

Organizations wanting to optimize their operations are increasingly choosing Business Process Management for implementation. The goal of Business Process Management employment is the optimizing of support applications, managing workflow and flow control, and the use of data from existing databases to complete necessary document parts.

The purpose of this article is to identify the economic benefits for organizations that result from the implementation of both the BPM concept and the BPMN class IT system.

Interest in business modeling and review of relevant literature facilitate understanding and observing the many changes occurring in the contemporary approach to the presentation of phenomena through modeling as well as the drawing of appropriate conclusions.

Action research played a key role in the preparing of this article. Thanks to action research, it was possible to conduct a number of in-depth interviews as well as participate in many projects using BPM and BPMN. This study applied deductive reasoning based on analysis of extensive literature. Reflections found in the work are based on the current literature.

\section{BPMN}

Use case descriptions and the documentation of complex procedures are often very difficult to understand as well as being error prone. Since a (more or less) clear picture depicting either a workflow or a business process is, in most cases, self-explanatory, many users strive to enrich the descriptions 
of processes with diagrams in order to better convey the intended meaning associated with the process. Moreover, examining a graphical description of a process allows users to easily discover inconsistencies and/or differences in names or acronyms, infinite loops, non-terminating conditions, etc. Using a formal graphical notation is the de facto standard choice to express a representation of a process that should be syntactically valid (thus assuring consistency with the represented process) and have the same meaning as the (usually, natural language based) textual description of the process (Chinosi and Trombetta, 2012, pp. 124-134).

BPMN process models are composed of:

(i) Activity nodes denoting business events or items of work performed by human beings or by software applications, and

(ii) Control nodes that capture the flow of control among activities.

Activity nodes and control nodes can be connected by means of a flow relation in almost arbitrary ways (Remco Dijkman, Marlon Dumas, and Chun Ouyang, 2008, pp. 1281-1294).

A BPMN process is made up of BPMN elements. These include objects, sequence flows, and message flows. An object can be an event, activity, or gateway. A sequence flow links two objects in a process diagram and denotes a control flow (i.e. ordering) relation. Message flows are used to capture the interaction between processes. The figure does not show BPMN elements that do not have a control-flow semantics, such as lanes, artifacts, groups, and associations (Remco Dijkman, Marlon Dumas, and Chun Ouyang, 2008, pp. 1281-1294).

An event may signal the start of a process (start event), the end of a process (end event), and may also occur during the process (intermediate event). A message event is used to send or receive a message. A timer event indicates that a given time instant has been reached, while an error event signals a fault or exception raised during the process. There are other types of events in BPMN, including link events, rule events, terminate events, and compensation events. Link events are a notational convenience for spreading a model onto several "pages." For this reason they do not affect the semantics of a model. Rule events are similar to message events. They only differ in the way they are triggered. Rule events are triggered by data updates while message events are triggered by the arrival of messages. For the purposes of this work, it was found that they can be treated in very similar ways. Correspondingly, terminate events can be treated as a special type of error event. Finally, compensation events are outside the scope of this paper. An activity can be a task or a subprocess. A task is an atomic activity standing for work to be performed. There are seven task types: service, receive, send, user, script, manual, and reference. A subprocess is 
a compound activity defined as a flow of other activities. It can be invoked via a subprocess invocation activity. Subprocesses can be embedded and independent. An embedded subprocess is part of a process while an independent one can be called by different processes. Moreover, an activity may have attributes specifying additional behavior, such as looping and multiple parallel instances. A gateway is defined as a routing construct. There are parallel fork gateways (AND-split) for creating concurrent (sequence) flows, parallel join gateways (AND-join) for synchronizing concurrent flows, data/event-based XOR decision gateways for selecting one out of a set of mutually exclusive alternative flows, where the choice is based on either the process data (data-based, i.e. XOR-split) or an external event (event-based, i.e. deferred choice), XOR merge gateways (XOR-join) for joining a set of mutually exclusive alternative flows into one flow, and inclusive OR decision gateways (OR-split) for selecting any number of branches among all outgoing flows. In particular, an event-based XOR decision gateway must be followed by either receive tasks or intermediate events to capture race conditions based on timing or external triggers (e.g., the receipt of a message from an external partner). An intermediate message, timer, or error event attached to the boundary of an activity signals an exception, called an "exception event." The occurrence of the activity will be interrupted upon the occurrence of the exception and process execution along the normal sequence flow will switch to the exception flow at the point at which the exception occurs. It should be noted that an error event on a normal sequence flow models "throwing" an error, while one attached to the boundary of the activity models "catching" an error. This is similar to the strictly hierarchical throw-catch mechanism used in most programming languages. A message flow is used to show the transmission of messages between two interacting processes via communication actions such as a send/receive task or message event. The two processes are located, respectively, within two separate pools representing two participants (e.g., business entities or roles). In graphical representation, a message flow is drawn as a dashed line with an open arrowhead connected to the target process and a circle connected to the source process. A pool is drawn as a rectangle labeled with the process name (Remco Dijkman, Marlon Dumas, and Chun Ouyang, 2008, pp. 1281-1294). Finally, a BPMN model is composed of a set of BPMN processes that are related to each other via subprocess invocation activities or message flows.

BPMN 2.0 is used by nearly $40 \%$ of the interviewed users, where almost $30 \%$ use BPMN 1.2 and $15 \%$ use a combination of both. BPMN is used mainly for documentation purposes (52\%) and executing business processes (37\%). Simulation of processes is quite important in and of itself (11\%), even if in 
most cases the simulation of processes is embedded inside the execution environment. Process types usually modeled using BPMN are business processes and administrative procedures (booking resources, documentation flow, etc.). Both in conjunction represent half of the collected answers (where business processes received a score of $32.14 \%$ while administrative procedures received one of $17.86 \%$ ). In examining the results, $12 \%$ of the interviewees used BPMN to model generic workflows while only $7.14 \%$ of them adopted BPMN to model a supply chain. Near the end of the list are data flows-not surprisingly, considering that "while BPMN shows the flow of data (Messages) and the association of data artifacts to Activities, it is not a data flow language"-medical procedures, online store procedures, and environmental processes (less than 2\%) (OMG, 2011).

Business Process Management is aimed at maintaining supported documents and manage their workflow and flow control. Working with the system includes (Zaskórski, 2005, pp. 158-176):

(i) Initiating the process of creating a document by a user who is in the group of operators,

(ii) Completion of an application form or a contract with the use of data contained in dictionaries, original documents, and the database by directly inserting them into the document,

(iii) Use of data contained in traditional documents,

(v) Checking forms with respect to substance and form,

(iv) Automatic validation of numerical values in a document,

(vi) Use of a register of applications for financing to complete contract value,

(vii) Verification and improvement of forms by authorized personnel,

(viii) Exchange of information among users involved in the process of the formation of the target document-consultation, escalation, and delegation of the document,

(ix) Approval of a document and assigning its causative power,

(x) Data storage dedicated to each application/agreement register with the possibility of access at every level of the service document, which is conditional on user rights held by the current user,

(xi) Access to the register for each document, where it is possible to view the status of a document, which allows the current track,

(xii) Automatic updating of registry data after the approval of each task by the user, allowing access to current data,

(xiii) Recording of all actions carried out during the task process by users who have been assigned appropriate permissions-records archived in the history of the graphic and textual process as well as the specific task, and 
(xiv) A recording system for scanning original documents in traditional form and recording the documents in a document repository, which allows direct access to the original documents for duly authorized users.

\section{The Benefits of BPMN Class IT System Implementation}

Implementation of three HR processes (over 7,000 employees)-requests for leave, overtime requests, and requests for business trips and their settlement. There were many benefits for the organization after implementation. Of the fifteen people dealing with the handling of paper applications, five now remain with a target of one or two people (annual estimated return: 360,000 net per year). Shortening the time needed to handle applications by $30-60 \%$ thanks to standardizing procedures, automatic downloading and transfer of current data to the payroll system, and no "lost" documents. Savings on paper and printing equipment is estimated at a minimum of 150,000 sheets per year-a parameter that is dependent on the number of processes per year.

Implementation of seven human and operational processes (over 1,500 employees). There were many benefits for the organization after implementation, including a shortening of processing time by $30-40 \%$, automatic downloading and transfer of current data to the payroll and field systems, and no "lost" documents. Off-loading staff members by providing information on "vacation status" to each logged-in user. Arranging procedures and decision paths, especially for requests from external applicants. Savings on paper and printing equipment estimated at a minimum of 45,000 sheets per year- a parameter that is dependent on the number of processes per year.

Implementation of ten operational processes in an organization operating on the insurance and banking markets (fifteen employees). There were many benefits for the organization after implementation. Reduced processing time by $30-90 \%$ (highest in the case of the contract and transaction registration process). Reporting automation enabling automatic and immediate financial information acquisition (formerly manual data acquisition and excel processing taking one minute). Savings on paper and printing equipment estimated at about 64,000 sheets per year-a parameter that is dependent on the number of processes per year.

Implementation of fourteen processes for handling subsidy mechanisms for both central and branch offices (about 1,000 people). There were many benefits for the organization after implementation. Automation 
of mathematical calculations. A 30\% reduction in handling time for a single application. Integration with the product systems allowing single sign-on and avoiding data redundancy. Arranging procedures and decision paths.

Implementation of ten operational processes. There were many benefits for the organization after implementation. Automation of processes for handling and managing large volumes of data. Shortened processing time by more than $60 \%$. Automation of $80 \%$ of activities previously performed by employees. Standardization of operations and validation for all input data of the same type.

\section{Immediate Reporting of Processing Status: The Benefits of BPM Concept Implementation}

Many benefits were noted after implementation the BPM concept:

- Better protection of the document databases,

- Improved access management to documents,

- Tracing of the history of document workflow and generating reports,

- Efficient archiving of documents,

- Standardized document templates thanks to previously defined formulas,

- Parallel processing of documents for different organizations by the user,

- Automation and optimizing of document creation,

- Consistency and uniformity in the produced documents,

- Validations safeguarding the user's actions,

- Faster use of larger amounts of information, allowing shorter document circulation time,

- Increased safety and reliability of produced documents,

- Minimizing document circulation problems and paths,

- Ability to provide documentation for individual users and the groups to which they belong,

- Reducing application volume while maintaining necessary content, which increases application readability,

- Paper and printing device savings,

- Reduction in the number of process steps and the elimination of errors through automation,

- Reduction in job positions responsible for the management of paper documents, 
- Shortening document servicing as well as related tasks through procedure standardization,

- Validation and standardization of operations for all input data of the same type,

- Clarification of the scope of duties of each employee through the assignment of concrete steps in the business process,

- Facilitated implementation of changes by centrally defining the process model,

- Ordering decision-making paths,

- Increased productivity by reducing process time,

- Automatic downloading and transfer of data to the current system,

- Automated reporting that extracts needed information automatically and immediately,

- Automation of mathematical calculations,

- Automation of tasks previously performed by employees,

- Current reporting of actual processes, their state, and the state of implementation delays,

- Immediate ability to report processing status, and

- Optimizing the use of staff, including the ability to move resources as necessary to implement specific business processes.

\section{Data Monitoring}

Today's world necessitates an abstract interpretation of a realm that tolerates disturbances while still being close enough to give an idea of how data about it are interrelated. The conceptual design that provides such an interpretation is called the "data model." It is a model that provides a reasonable interpretation of the data.

The data model is a way of abstraction that allows the seeing of the information carried by the data, not individual data values. Many fields of human knowledge refer to models and use them to gain greater clarity and arrive at details (Tsichritzis and Lochovsky, 1990, pp. 20-27).

Data models allow for the partial grasping of the significance of data in conjunction with a full understanding of the world, providing partial knowledge of it.

The data mostly consist of facts, figures, names, or marks showing results and observations. Data taken out of context have no intrinsic significance or any importance of their compounds because they are related to neither time nor space. Data can be saved on media using suitable devices (Brooking, 1999, pp. 4-5). 
Selected, summarized, compared, and grouped together as well as factually and logically ordered to be used as decision-making data that are properly assessed on the basis of certain criteria, they are beginning to be useful and gaining new and higher quality as well as becoming information. The word information comes from the Latin informare, which means to give form. Therefore, the decision-makers in any organization observe data and logical relations as well as substantial overlapping between them, where thanks to their proper matching, ordering, and reason-based combining they obtain information. Information, when compared with the data, has purpose, meaning, and significance. Information assigns a precise location in context for the data, the environment, and time, changing the perception of things and objects.

Open, dynamic, and integrated collections of information placed in a social, organizational, and economic context that are submitted for judgment create knowledge. Knowledge goes beyond information for troubleshooting; it can be taken as respectively numbered action. Knowledge is characterized by dynamism, intuitiveness, and subjectivity, allowing predictions of the future. Data and information are, however, an objective and static picture of facts. Knowledge has a direct impact on change or decisions. Information is used in the practice of knowledge, the quality of which is manifested in operations and use. Knowledge arises in the mind of Man. It is identified with a set of rules of conduct in the sphere of abstract thinking applied to information, which orders base facts. Knowledge, therefore, is information together with the meaning thereof.

Data and information can exist outside the human mind, but knowledge is created exclusively by human beings (Strojny, 1999, pp. 4-7). Knowledge is closely linked with the person or institution holder, while information can exist independently (e.g., in the form of a document). Information is often confused with knowledge because both information and knowledge circulate within the organization through structural network management systems and organization (Grudzewski and Hejduk, 2003, p. 8). Information becomes knowledge at the moment of its interpretation by Man. Competences vested in the person interpreting and presenting the information determine whether the information becomes knowledge. Not every person will place the information in the same context. Interpretation of information-the creation of knowledge-is achieved through reflection, associating facts, experience, and intuition.

The use of the BPM system to handle electronic versions of applications and contracts and record them in dedicated registers leads to the analysis of supported documents and the keeping of statistics on the service. 


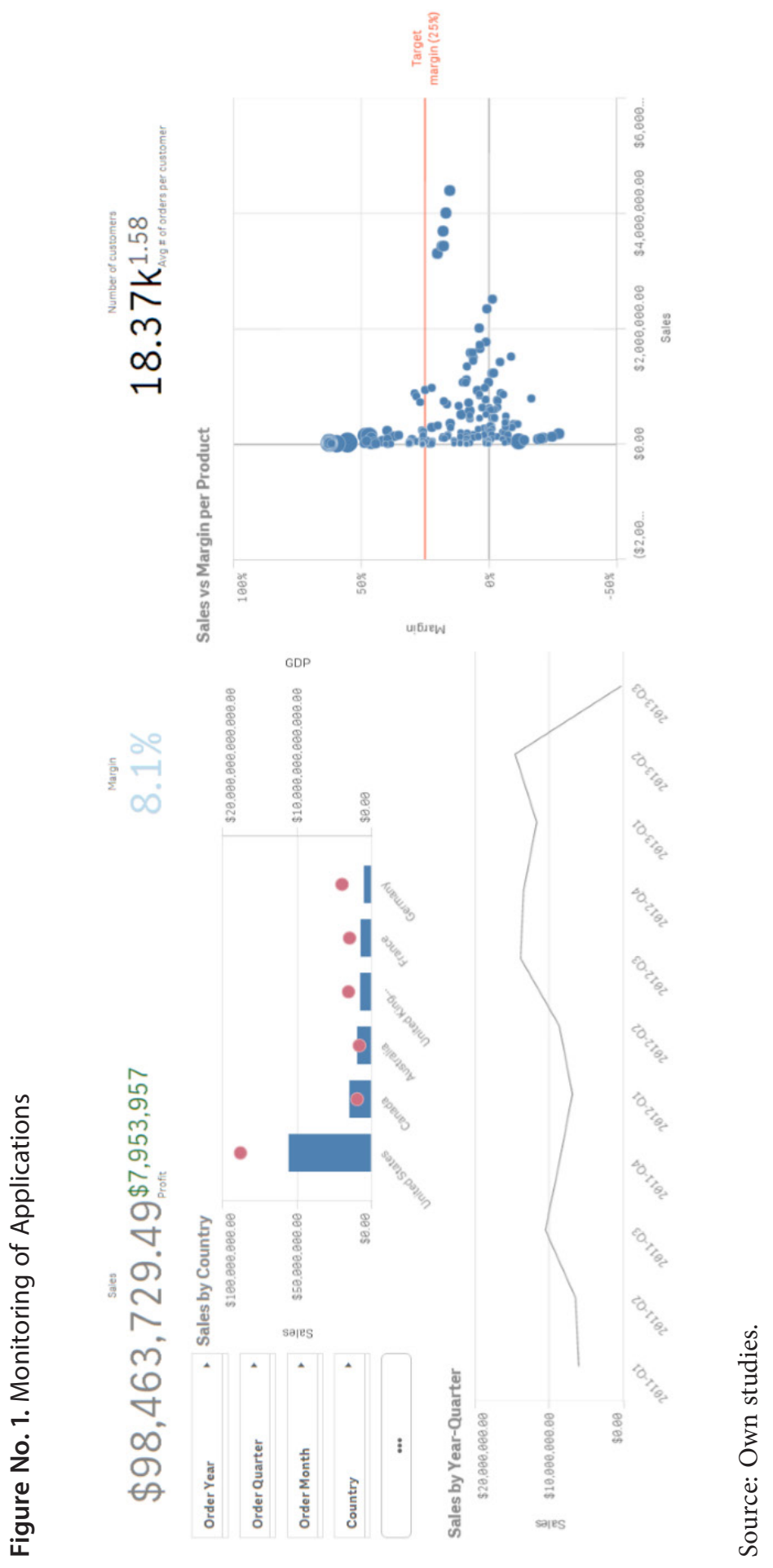


The system can generate various types of charts to illustrate the collected data, taking into account various parameters. The most commonly used graphs show the number of applications by ownership status. With appropriate data it is possible to transform this into knowledge relating to the functioning of the organization.

The following graphs (Figure No. 1) illustrate an example of a summary of the data contained in the Aurea BPM system, which can be presented using different types of charts taking into account various factors.

\section{Summary}

Data processed by business processes make up successive diagrams of processes-the most important aspect of their formal description. The emergence of data initializes data supplemented and modified during the process, where the processes also produce data that are transmitted outside the organization-e.g., in the form of reports or other documents. Additionally, the data are involved in processing algorithms based on conversion, where values are entered by the operator or determined automatically. Ultimately, the process depends on the controlled gateway decision.

The growing popularity of BPMN can lead to the dominance of this notation not only in the specification of IT requirements, but also in other applications that require process modeling for the needs of business process management.

The popularity of BPMN among IT analysts and designers can help to better understand the essence of the process approach in this professional group, which may consequently affect better adapting IT functions to process management.

\section{References}

Bandara, W., Gable, G.G., and Rosemann, M. (2014). Factors and Measures of Business Process Modeling: Model Building Through a Multiple Case Study. European Journal of Information Systems, 4(14).

Brooking, A. (1999). Corporate Memory: Strategies for Knowledge Memory. International Thomson Business Press.

Chinosi, M. and Trombetta, A. (2012). BPMN: An Introduction to the Standard, Computer Standards \& Interfaces, Elsevier, 34.

Davenport, T.H. (2005). The Coming Commoditization of Processes. Harvard Business Review, $6(83)$. 
Davies, I. et al. (2006). How Do Practitioners Use Conceptual Modeling in Practice? Data \& Knowledge Engineering, 3(58).

Gartner Group. (2009). Meeting the Challenge: The 2009 CIO Agenda. EXP Premier Report. January 2009. Gartner, Inc., Stamford, Connecticut.

Grudzewski, W.M. and Hejduk, I. (2003). Zarządzanie wiedzą wyzwaniem dla współczesnych przedsiębiorstw [Managing knowledge: A challenge for contemporary companies]. Ekonomia i Organizacja Przedsiębiorstwa [Economics and Company Organization], 1. http://www.bpmn.org (16.11.2016).

Kolbusz, E., Olejniczak, W., and Szyjewski, Z. (2005). Inżynieria systemów informatycznych $w$ e-gospodarce [The engineering of information systems in an e-economy]. Warsaw: PWE Polish Economic Publisers.

OMG. (2005). Unified Modeling Language: Superstructure, UML Superstructure Specification v2.0, formal/05-07-04, Object Management Group.

OMG. (2006). Business Process Modeling Notation (BPMN) Version 1.0. OMGFinal Adopted Specification, Object Management Group.

OMG. (2011). Business Process Model and Notation (BPMN 2.0), formal/2011-01-03, OMG, http://www.omg.org/spec/BPMN/2.0.

Piotrowski, M. (2007). Notacja definiowania procesów biznesowych [Notation for defining business processes]. BTC.

Remco Dijkman, M., Dumas, M. and Ouyang, Ch. (2008). Semantics and Analysis of Business Process Models in BPMN, Information and Software Technology, 50.

Rosemann, M. (2006). Potential Pitfalls of Process Modeling: Part A. Business Process Management Journal, 12(2).

Scheer, A.-W. (2000). ARIS-Business Process Modeling, 3rd Edition. Springer.

Strojny, ,M. (1999). Zarządzanie wiedzą i kapitałem intelektualnym jako nowe źródło przewagi i konkurencyjnej [Knowledge and intellectual capital management as a new source of advantage and competitiveness]. Problemy Jakości [Questions of Quality], 12.

Tsichritzis, D.C., Lochovsky, F. H. (1990). Modele danych. Wydawnictwo Naukowo Techniczne. WFMC, Workflow Management Coalition Workflow Standard: Workflow Process Definition Interface - XML Process Definition Language (XPDL), Technical Report, Workflow Management Coalition, 2002, Lighthouse Point, Florida, USA, 2002.

Zaskórski, P. (2005) Strategie informacyjne $w$ zarządzaniu organizacjami gospodarczymi [Information strategies in managing economic organizations]. Warsaw: Warsaw University of Technology. 
Część III

\section{Polski kontekst}





\section{Olga Irodenko*}

\section{Czynniki efektywności audytu wewnętrznego jako istotnego elementu zarządzania przedsiębiorstwem - badanie teoretyczne}

Głównym celem artykułu jest przedstawienie, oparte na kompleksowej analizie literatury światowej, czynników mających wpływ na efektywność funkcjonowania audytu wewnętrznego w przedsiębiorstwach. Pierwsza część artykułu ma charakter wprowadzający i obejmuje genezę i rozwój audytu wewnętrznego jako nowoczesnego instrumentu zarządzania przedsiębiorstwem. Następna - przedstawia funkcję audytu wewnętrznego na tle dorobku nauk o zarządzaniu. Ostatnia część poświęcona jest analizie literatury zagranicznej z zakresu badań naukowych nad efektywnością funkcjonowania komórki audytu wewnętrznego w przedsiębiorstwach. W wyniku tej analizy wyodrębnione zostały czynniki efektywności audytu wewnętrznego.

Słowa kluczowe: audyt wewnętrzny, efektywność, zarządzanie przedsiębiorstwem, wartość dodana.

\section{Determinants of internal audit effectiveness as an important element of organization management: a theoretical study}

The purpose of this paper is to present, based on world literature review, the factors of the internal audit effectiveness. The first part of the article introduce the genesis and the development of internal audit in enterprise as a modern management tool. The next chapter presents the role of internal audit represented by management sciences. The last part of the article is devoted to analysis of foreign literature in the field of research on the internal audit effectiveness in enterprises. As a result of this analysis were separated factors of internal audit performance.

Keywords: internal audit, efficiency, management, value adding.

JEL: M420

\footnotetext{
* Olga Irodenko, mgr - olgaiko@yahoo.com.
} 


\section{Wprowadzenie}

Rola audytu wewnętrznego we współczesnym środowisku rozwoju przedsiębiorczości stale ewoluuje i rozszerza zakres swoich czynności wraz ze zmianami w otoczeniu gospodarczym, społecznym, prawnym, informacyjnym i technologicznym.

Zdaniem P.F. Druckera (1999), współczesne uwarunkowania funkcjonowania przedsiębiorstw wymagają umiejętności szybkiego identyfikowania szans i zagrożeń oraz podejmowania trafnych decyzji. Znaczenia nabiera transparentność działań, spójność polityki informacyjnej oraz otwartość na zmiany przez pryzmat efektywnego zarządzania aktywami firmy. Osiągnięcie celów, sformułowanych i przyjętych w strategii organizacji, wymaga stosowania odpowiednich metod, procedur i narzędzi zarządzania.

Obecnie audyt wewnętrzny jest traktowany jako integralna część zarządzania i istotny element silnego ładu korporacyjnego przedsiębiorstwa. Dynamiczne zmiany w gospodarce światowej, złożoność regulacji prawnych, postęp technologiczny w ostatnich latach wyznaczyły nowe narzędzia i kierunki rozwoju audytu wewnętrznego, wspomagające zarządzanie i kreujące wartość dodaną organizacji. Możliwości te zaowocowały również nowym wizerunkiem audytora wewnętrznego $\mathrm{z}$ rozszerzonym, dostosowanym do wymagań otoczenia zestawem umiejętności i dobrych praktyk.

W sytuacji wzrostu zapotrzebowania w usługach audytora pojawiają się naukowe i praktyczne rozważania w kierunku oceny efektywności komórki audytu wewnętrznego $\mathrm{w}$ przedsiębiorstwie. Opracowania w tym zakresie poszukują właściwych mierników oceny czynności audytorskich, od strony zarówno teoretycznej, jak i praktycznej, wykonywanych przez naukowców z różnych krajów oraz członków Stowarzyszenia Instytutu Audytorów Wewnętrznych.

Określenie czynników mających wpływ na efektywność audytu wewnętrznego w organizacji dotyczy obszaru problemowego związanego $\mathrm{z}$ oceną efektywności komórki audytu. Opracowanie zamierza przedstawić funkcję audytu wewnętrznego jako efektywnego instrumentu zarządzania przedsiębiorstwem na tle dorobku nauk o zarządzaniu. Przeprowadzone badania o charakterze teoretycznym, bazując na przeglądzie zagranicznej literatury naukowej, mają na celu opisanie głównych czynników efektywności audytu wewnętrznego. Praca jest próbą głębszego zrozumienia istoty i roli audytu wewnętrznego $\mathrm{w}$ zarządzaniu przedsiębiorstwem oraz określenia i analizy czynników mających wpływ na jego efektywność. 


\section{Geneza i rozwój audytu wewnętrznego we współczesnym zarządzaniu przedsiębiorstwem}

Filozofia audytu wewnętrznego pochodzi ze Stanów Zjednoczonych i powstała głównie na skutek utworzenia Amerykańskiej Komisji Papierów Wartościowych i Giełd (U.S. Securities and Exchange Commission - SEC) oraz w wyniku modyfikacji celów i technik audytu zewnętrznego w tamtym okresie. W zakresie kontrolnych działań legislacyjnych SEC zaczęła wymagać, aby zarejestrowane przez nią spółki dostarczały sprawozdania finansowe potwierdzone przez niezależnych audytorów. Wymagania te skłoniły spółki do utworzenia działów audytu, których podstawowym zadaniem miało być wspieranie audytorów zewnętrznych (Lisiński, 2011, s. 27).

W 1941 r. powstało międzynarodowe stowarzyszenie, Instytut Audytorów Wewnętrznych (The Institute of Internal Auditors - IIA), które już po kilku latach istnienia poczyniło ogromne postępy $\mathrm{w}$ rozpowszechnianiu idei audytu w przedsiębiorstwach.

IIA prowadziło działalność w zakresie organizowania konferencji naukowych, publikacji raportów z przeprowadzonych badań, gromadzenia przedstawicieli nauki i biznesu. Czynności te doprowadziły do sformułowania pierwszej współczesnej definicji audytu wewnętrznego oraz opracowania standardów zawodowych audytu wewnętrznego, stanowiących wzorzec dla audytorów wewnętrznych na całym świecie.

Nasilenie konkurencji, niestabilna polityka władz państwowych, innowacje techniczne, ogólnoświatowe trendy internacjonalizacji oraz rozwój rynków kapitałowych w drugiej połowie XX w. skutkowały rozwojem nowego obszaru badawczego w naukach o zarządzaniu, związanego z problematyką kontroli. Powstawały również nowe techniki i formy kontroli. W tym czasie swoje prace tworzyli amerykańscy naukowcy Ch.I. Barnard, H. Koontz i C. O’Donnell. Przez następne kilkanaście lat definicja, funkcje oraz zakres audytu wewnętrznego stale ewaluowały, a wszelkie nowe zjawiska i procesy zmian w gospodarce wywierały znaczący wpływ na te przeobrażenia (Lisiński, 2011).

Ewolucję roli audytu wewnętrznego w zarządzaniu przedsiębiorstwem można zauważyć na tle zmian jego zakresu pojęciowego. Wszystkie zmiany znajdują odzwierciedlenie $\mathrm{w}$ treści sformułowanych definicji audytu wewnętrznego. Analizując literaturę przedmiotu, stwierdzono, że w ciągu kilkudziesięciu ostatnich lat podjęto wiele prób znalezienia definicji audytu wewnętrznego.

W pierwszej definicji Instytutu Audytorów Wewnętrznych eksponowany były aspekty finansowy i księgowy, następne zmiany dotyczyły rozszerzenia 
zadań w zakresie oceny i przeglądu zarządzania. Dalsze zmiany definicji podkreślały funkcje kontrolną i oceniającą, dotyczące funkcjonowania i rozwoju organizacji. W $2001 \mathrm{r}$. IIA przyjął ostateczną wersję definicji audytu wewnętrznego: „Audyt wewnętrzny jest działalnością niezależną i obiektywną, której celem jest przysporzenie wartości i usprawnienie działalności operacyjnej organizacji. Polega na systematycznej i dokonywanej w uporządkowany sposób ocenie procesów: zarządzania ryzykiem, kontroli i ładu organizacyjnego, i przyczynia się do poprawy ich działania. Pomaga organizacji osiągnąć cele, dostarczając zapewnienia o skuteczności tych procesów, jak również poprzez doradztwo" (IIA, 2011).

Zgodnie z obowiązującą definicją Instytutu Audytorów Wewnętrznych rola audytu wewnętrznego polega na przysporzeniu wartości i usprawnieniu działalności operacyjnej organizacji poprzez pełnienie funkcji zapewniającej i doradczej oraz systematyczną ocenę procesów zarządzania ryzykiem, kontroli i ładu organizacyjnego.

Audytorzy wewnętrzni początkowo odpowiedzialni byli za poprawność danych finansowych organizacji. Nowoczesny audyt natomiast poszerzył swój zakres o ocenę efektywności systemu kontroli wewnętrznej i wydajności działalności operacyjnej. Zasadniczą jest zmiana orientacji audytu wewnętrznego $\mathrm{z}$ funkcji rachunkowo-księgowej na funkcję biznesowo-zarządczą. Twierdzenia te znajdują swoje potwierdzenie w pracach Chapmana i Andersona (2002), którzy podkreślają istotę funkcji zapewniającej i doradczej audytu wewnętrznego.

Nowoczesny audyt wewnętrzny to działalność zorientowana na ryzyko towarzyszące działalności organizacji (Roth, 2002). Rola audytu zaczęła poszerzać zakres swoich czynności na rozwój strategiczny organizacji funkcja audytu wewnętrznego, która wspiera cele strategiczne organizacji.

Analizując rozwój definicji audytu wewnętrznego w jego podstawowym nurcie, wyznaczonym przedsięwzięciami podejmowanymi przez IIA, można zauważyć, że przyczyną zmian był rozwój otoczenia, w którym przyszło funkcjonować przedsiębiorstwom. To on wymuszał zmiany w treści audytu wewnętrznego oraz korygował poglądy na możliwości jego wykorzystania.

Zasadnicza zmiana podejścia do roli audytu wewnętrznego w organizacji jest związana ze światowymi aferami WorldCom i Enron, które manipulowały danymi w księgach, głównie po to, aby finansowy wizerunek organizacji odpowiadał oczekiwaniom inwestorów na Wall Street.

Po wielkich aferach finansowych podstawowym zadaniem audytora wewnętrznego było przywrócenie zaufania i niezależności, zapewnienie inwestorów i akcjonariuszy w przejrzystości danych finansowych oraz kompatybilności stosowanych mechanizmów kontrolnych z rozwojem strategicznym organizacji. 
Podstawowym czynnikiem, który spowodował zmianę pozycji audytorów wewnętrznych, najpierw w Stanach Zjednoczonych, a później na całym świecie, było uchwalenie ustawy Sarbanesa - Oxleya przez Kongres Stanów Zjednoczonych w 2002 roku (Anderson, Christ, Johnstone, i Rittenberg, 2012, s. 167-191). Ustawa ta wprowadziła wymóg dodatkowych ujawnień dokonywanych przez zarząd, dotyczących efektywności systemu kontroli wewnętrznej. Nałożyła także obowiązek kontroli jakości usług audytorskich, dodatkowe finansowe i karne sankcje dla władz spółek w przypadku wykrycia błędów w sprawozdaniach finansowych oraz wprowadziła bezwzględny wymóg niezależności audytora (Hass, Abdolmohammadi i Burnaby, 2006).

Audyt wewnętrzny rozszerza obecnie zakres swoich czynności na wszystkie obszary działalności operacyjnej przedsiębiorstwa i staje się cenionym elementem zarządzania (Moeller, 2015, s. 31).

Dynamiczne otoczenie gospodarcze oraz potrzeby rynkowe generują nowe doskonalone praktyki audytu wewnętrznego. Zadaniem audytora jest zrozumienie obecnych potrzeb organizacji przy zastosowaniu właściwych rozwiązań w procesie zarządzania. Istotnego znaczenia nabiera kreatywne myślenie i umiejętność komunikowania się.

Podsumowując proces ewolucji i rozwoju audytu wewnętrznego, naukowcy wyróżniają pięć jego generacji (zob. tab. 1).

Tabela 1. Generacje audytu wewnętrznego

\begin{tabular}{|c|l|l|}
\hline Generacja & \multicolumn{1}{|c|}{ Okres } & \multicolumn{1}{c|}{ Główne cechy } \\
\hline I & lata 40.-70. XX w. & $\begin{array}{l}\text { koncentracja uwagi na systemie kontroli wewnętrznej } \\
\text { i na weryfikacji zgodności procesów ze stanem udo- } \\
\text { kumentowanym w procedurach (ex post) }\end{array}$ \\
\hline II & lata 80. XX w. & $\begin{array}{l}\text { ewaluacja od charakteru ex post do ex ante; rozsze- } \\
\text { rzanie przedmiotowego zakresu audytu przez objęcie } \\
\text { nim weryfikacji i oceny efektywności stosowanych } \\
\text { procedur kontroli wewnętrznej oraz analizy różnych } \\
\text { rodzajów ryzyka finansowego }\end{array}$ \\
\hline III & lata 90. XX w. & $\begin{array}{l}\text { określone działania audytu wewnętrznego, które wpi- } \\
\text { sują się w koncepcję nadzoru korporacyjnego; dalsze } \\
\text { rozszerzanie treści audytu wewnętrznego, który obej- } \\
\text { muje oprócz ryzyka finansowego analizę ryzyka ope- } \\
\text { racyjnego; a wewnętrzny staje się składnikiem pro- } \\
\text { cesu zarządzania instytucją }\end{array}$ \\
\hline IV & $\begin{array}{l}\text { przełom XX i XXI w. } \\
\text { - nasze czasy }\end{array}$ & $\begin{array}{l}\text { radykalne zmiany w prawodawstwie, głównie ame- } \\
\text { rykańskim, wyznaczające rygorystyczne ramy for- } \\
\text { malno-prawne; audyt wewnętrzny coraz częściej jest } \\
\text { wykorzystywany w procesie zarządzania organizacją }\end{array}$ \\
\hline
\end{tabular}




\begin{tabular}{|l|l|l|}
\hline \multirow{2}{*}{ V } & $\begin{array}{l}\text { sięgnięcie do korzeni misji audytu wewnętrznego, } \\
\text { zaproponowanej przez twórców IIA: istota audytu } \\
\text { - instrument doskonalenia funkcjonowania instytu- } \\
\text { cji; dwie podstawowe funkcje - kontrolna i doradcza; } \\
\text { odwołanie się do dorobku nauk ekonomicznych } \\
\text { i społecznych w celu ich wykorzystania w tworzeniu } \\
\text { nowej koncepcji audytu wewnętrznego }\end{array}$ \\
\hline
\end{tabular}

Źródło: opracowanie własne na podstawie: Lisiński (2011, s. 32-35).

\section{Audyt wewnętrzny na tle dorobku nauk o zarządzaniu}

W naukach o zarządzaniu audyt wewnętrzny, jako funkcja zapewniająca i przynosząca wartość dodaną organizacji, przedstawiony jest między innymi w pracach naukowych Goodwina, Sawyera, Saundersa, Moellera, Rotha, Gramlinga, Arena, Azzone, Bou-Raada i Enyue.

Szerokie podejście do audytu demonstruje książka amerykańskiego naukowca Sawyera pt. Sawyer's Internal Auditing, gdzie określone są cechy audytu i jego zakres przedmiotowy. Autor definiuje współczesny audyt wewnętrzny jako umiejętność prowadzenia rachunkowości, przeobrażonej w zawód ukierunkowany na zarządzanie. Swego czasu audyt koncentrował się na poświadczaniu dokładności danych finansowych. Obecnie świadczy usługi, które obejmują badania i ocenę zarówno kontroli, jak i całej działalności jednostek publicznych i prywatnych. Zwraca też uwagę na osiąganie celów strategicznych. (Lawrence, Sawyer, Dittenhofer i Scheiner, 2003).

James Roth (2002), który jest autorem licznych artykułów z zakresu kontroli wewnętrznej i ładu korporacyjnego, w swoich badaniach opisuje proces zmiany roli audytora wewnętrznego na przestrzeni lat $-\mathrm{z}$ kontrolera analizującego wydarzenia post factum na kontrolera reagującego na zgłaszane nieprawidłowości, a następnie na doradcę w procesie zarządzania ryzykiem.

Robert Moeller (2015) w swoim przewodniku po procesach i narzędziach audytu wewnętrznego pokazuje, w jaki sposób audyt wewnętrzny może lepiej służyć komitetowi audytu przy zarządzie. Jego twierdzenie o kluczowej roli audytu wewnętrznego w tworzeniu wartości dodanej środowiska ładu korporacyjnego przedsiębiorstwa rozwija się dalej w naukach o zarządzaniu.

Audyt wewnętrzny według E.J. Saundersa (1985, s. 35) jest profesjonalną działalnością oceniająca efektywność systemu kontroli wewnętrznej i zarządzania ryzykiem oraz działalność doradczą. Saunders wyodrębnia następujące zadania audytu wewnętrznego: 
1. Czuwanie nad ochroną interesów i dobrym wizerunkiem przedsiębiorstwa oraz nad bezpieczeństwem i prawidłowością operacji przedsiębiorstwa przez:

- ocenę systemu kontroli wewnętrznej, struktur organizacyjnych i administracyjnych przedsiębiorstwa, procesów zarządzania ryzykiem oraz stopnia ich dostosowania do aktualnych warunków;

- ocenę efektywności istniejących podziałów kompetencji wewnątrz instytucji oraz ich ścisłe przestrzeganie przez jednostki organizacyjne i osoby działające $\mathrm{w}$ imieniu przedsiębiorstwa;

- ocenę efektywności oraz prawidłowości wykonania wewnętrznie ustalonej strategii i polityki przedsiębiorstwa, wyrażonej formalnie wydanymi zarządzeniami i instrukcjami przez zarząd oraz systemu ich rozpowszechniania i w miarę możliwości zapewnienie, że są one ściśle przestrzegane przez wszystkie osoby i jednostki przedsiębiorstwa;

- czuwanie nad prawidłowością ujęcia w księgach wszystkich operacji przedsiębiorstwa zgodnie z prawem, przepisami organów nadzorczych przedsiębiorstw, statutem oraz ustalonymi wewnętrznie procedurami i zarządzeniami przedsiębiorstwa;

- zapewnienie poprawnego charakteru wszelkiej sprawozdawczości.

2. Wypełnianie swoich zadań przez proaktywną współpracę nad formułowaniem strategii i polityki przedsiębiorstwa, propozycjami zmian administracyjnych i organizacyjnych, inicjowanie przygotowania nowych zarządzeń i procedur wewnętrznych oraz implementacją nowych systemów komputerowych, telekomunikacyjnych. Zadania te realizowane są przez:

- badanie działalności przedsiębiorstwa oraz sporządzenie raportów pokontrolnych;

- przedstawienie odpowiednich poleceń pokontrolnych w celu usunięcia ujawnionych słabości, ograniczania przewidywanych strat, udoskonalenia jakości pracy oraz zmniejszenia kosztów;

- wydawanie opinii i formułowanie uwag, których celem jest przede wszystkim uwzględnienie czynników kontroli wewnętrznych i ich efektywności kosztowej.

3. Współpraca z organami zewnętrznymi, audytorami zewnętrznymi oraz innymi instytucjami.

Przegląd amerykańskiej literatury przedmiotu nauk o zarządzaniu również pokazuje proces rozwoju audytu wewnętrznego w odpowiedzi na zmiany w systemie gospodarki światowej. Wyniki wspólnych badań trzech amerykańskich badaczy nauk o zarządzaniu i rachunkowości Susan Hass, 
Mohammada J. Abdolmohammadi i Priscilli Burnaby (2006) udowodniły fakt, że zmiany, które kształtują zakres audytu wewnętrznego mają wpływ na wymagania i umiejętności audytorów wewnętrznych.

Al-Twaijry (2003) w swojej publikacji o rozwoju audytu wewnętrznego w Arabii Saudyjskiej próbuje udowodnić, na podstawie teorii instytucjonalnej, tezę, że audyt wewnętrzny może przysparzać wartość dodaną, pomagając organizacjom osiągnąć gospodarność, efektywności i skuteczność. Podobne podejście mają brytyjscy naukowcy L.F. Spira i M. Page (2016), którzy podkreślają rolę audytu wewnętrznego w konsultowaniu menedżerów i pracowników oraz doradztwie w procesie zarządzania ryzykiem organizacji.

W polskiej literaturze naukowej rola audytu wewnętrznego jako narzędzia wspierania organizacji $\mathrm{w}$ osiąganiu celów ujęta jest $\mathrm{w}$ pracach m.in. K. Czerwińskiego, A. Kostur, A. Herdan, T. Kiziukiewicza, A. Piaszczyka i K. Winiarkiej.

Analiza definicji audytu wewnętrznego zgodnie $\mathrm{z}$ międzynarodowymi standardami oraz przegląd literatury naukowej z zakresu audytu wskazuje na istotną rolę audytu wewnętrznego jako instrumentu efektywnego zarządzania przedsiębiorstwem.

\section{Analiza badań naukowych w zakresie istoty efektywności audytu wewnętrznego}

Odpowiedzialność i rola, jaką przypisano audytorom wewnętrznym, zdeterminowały konieczność pomiaru efektywności ich pracy. Wartość i efektywność usług audytorskich były przedmiotem wielu badań na międzynarodowej arenie nauk o zarządzaniu od czasu wybitnej pracy Simunica 1980 r., w której autor określił model kształtowania wartości usług audytorskich, porównując do ilości i jakości przeprowadzonych badań.

O'Keefe (1994) zaprezentował model teoretyczny efektywności audytu, uwzględniając zmienne nakładu pracy audytorów (ilość godzin jako nakłady lub input) i poziom pewności jako efekt zadania audytowego (output). Biorąc pod uwagę ograniczoną liczbę danych do badań empirycznych oraz niemierzalny charakter zmiennej poziomu pewności, zastosowanej w modelu teoretycznym O'Keefa, ciężko było uznać otrzymane wyniki wskaźnika efektywności za interpretowalne.

W.R. Knechel, P. Rouse i C. Schelleman (2009) zaproponowali alternatywny model badania efektywności procesu audytu na podstawie modelu Data Envelopment Analysis. Metoda ta została opracowana przez trzech amerykańskich naukowców A. Charnes, W.W. Cooper oraz E. Rhode 
i zaprezentowana po raz pierwszy w 1978 r. na łamach czasopisma European Journal of Operational Research. Naukowcy wprowadzili wskaźniki kosztów pracy (input - większe nakłady pracy automatycznie zwiększają koszty) i czas poświęcony na czynności zbierania dowodów zapewniających (output - więcej dowodów podnosi poziom zapewnienia) dla oceny efektywności audytu. Charakterystykę odbiorców usług (klientów) badacze przyjęli jako czynnik egzogenny, wpływający na proces przeprowadzenia audytu w całości. Próbę badawczą stanowiły procesy audytowe w międzynarodowych biurach rachunkowych w Stanach Zjednoczonych.

Knechel, Rouse i Schelleman (1994) przedstawili zmodyfikowany model produkcyjny usług audytorskich, oparty na podejściu Hackenbracka i Knechela, którzy poddali klasyfikacji czas i koszty pracy w zależności od poziomu hierarchii i rodzaju wykonywanej czynności audytowej (zob. rys. 1).

Rysunek 1. Rodzaje wykonywanych czynności audytowych

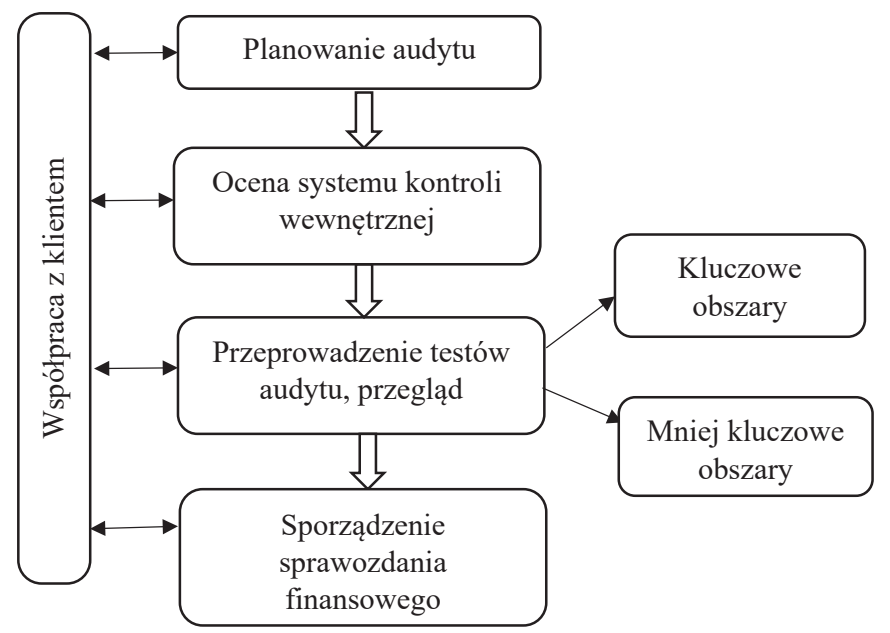

Źródło: opracowanie własne za: Knechel, Rouse i Schelleman (1994, s. 241-261).

Wyniki badań Knechela i in. (1994) przedstawiły wyższą efektywność audytu w większych firmach, w których rok obrotowy równa się kalendarzowemu oraz które mają zautomatyzowane procesy. Wyniki badań także wykazały, że w niektórych firmach mniejsza efektywność przeprowadzonego audytu była spowodowana spadkiem koszów wynagrodzeń audytorów.

Przedstawione wyniki analizy efektywności audytu przez pryzmat wysokości wynagrodzenia audytorów mogą kształtować się pod wpływem polityki cenowej firm oraz czynników konkurencji. Zastosowane mierniki w ograniczony sposób oceniają efektywność audytu, ponieważ nie uwzględniają 
podstawowych celów audytu wewnętrznego. Analiza skupia się raczej na pracy audytorów zewnętrznych w sektorze prywatnym.

W aspekcie praktycznym istotę efektywności sprowadza się do badania relacji ogółu efektów (wyników) działania do poniesionych w związku z tym nakładami przy użyciu formuły ilorazowej lub różnicowej. Wskaźniki efektywności sprawnego zarządzania organizacji zdefiniowali m.in. W. Kieżun (1997) i W. Gasparski (1983), określając ją jako relacje efektów (E) do kosztów $(\boldsymbol{K})$, gdzie relacja ta określana była jako efektywna, gdy wynik był wyższy od jedności, obojętna, gdy wynik równał się jeden i nieefektywna, gdy wynik był niższy od jedności.

$$
\begin{array}{lll}
\boldsymbol{E} / \boldsymbol{K} & >1 & \text { efektywna } \\
\boldsymbol{E} / \boldsymbol{K} & =1 & \text { obojętna } \\
\boldsymbol{E} / \boldsymbol{K} & <1 & \text { nieefektywna }
\end{array}
$$

Według Sawyera efektywność działalności komórki audytowej jest określana poprzez pryzmat jej zdolności do wydawania ustaleń i formułowania zaleceń w ramach prowadzonych prac audytorskich. Natomiast miarą skuteczności audytu jest liczba ich wdrożenia przez audytowane podmioty. Znaczenie audytu wewnętrznego z perspektywy wartości dodanej dla działalności organizacji umożliwia przyjęcie założenia, że audyt wewnętrzny jest efektywny.

Morrill w opracowaniu Internal auditors and the external audit: a transaction cost perspective oraz Krishnamoorthea w swojej pracy pod tytułem A multistage approach to external auditors evaluation of the internal audit function opisują wykorzystanie wyników przeprowadzonych audytów wewnętrznych przez biegłych rewidentów jako narzędzie przysporzenia wartości dodanej w postaci redukcji kosztów na audyt zewnętrzny.

Badania na podstawie teorii instytucjonalnej pokazują, że stopień efektywności audytu wewnętrznego ma tendencję do zmiany w zależności od kraju funkcjonowania oraz poziomu struktury organizacyjnej przedsiębiorstwa. Powyższe stwierdzenie znaleźć można w pracach Al-Twaijry i in. (2003) oraz Mihreta (2010).

Jednym z podejść do oceny efektywności audytu wewnętrznego jest badanie funkcji, która pomaga organizacjom w realizacji jej celów. Dotychczasowe badania empiryczne zależności wydajności organizacji (wydajność jako postęp w osiąganiu zaplanowanych celów) od efektywności funkcji audytu wewnętrznego nie pozwalają na stwierdzenie, że audyt wewnętrzny usprawnia działalność organizacji i przysparza wartość dodaną.

Ponadto, chociaż istniejące badania w zakresie efektywności komórki audytu wewnętrznego przypuszczają, że audyt wewnętrzny może nie zawsze 
być efektywny, badania te nie uzyskały jednoznacznej odpowiedzi na postawione pytania.

Wcześniejsze prace naukowe w zakresie audytu wewnętrznego głównie oparte są na teoriach neoklasycznych - teorii agencji (Adams, 1994) oraz teorii kosztów transakcji (Spraakman, 1997).

Mihret, James i Mula (2010) poddają krytyce stosowanie teorii neoklasycznych $\mathrm{w}$ próbach znalezienia istoty audytu wewnętrznego, przeciwstawiając im teorię instytucjonalną oraz teorię marksistowską. Barley i Tolbert (1997) w swojej publikacji pod tytułem Institutionalization and structuration: studying the link between action and institution na podstawie teorii instytucjonalnej wykazują związek pomiędzy istotnością czynników kulturowych i socjalnych mających wpływ na proces podejmowania decyzji.

Teoria instytucjonalna według Mihreta i in. (2010) umożliwia badanie efektywności audytu wewnętrznego z różnych perspektyw, uwzględniając determinanty efektywności audytu wewnętrznego w gospodarkach rozwiniętych oraz rozwijających się.

Niektórzy badacze określają przyszłe kierunki badań efektywności audytu wewnętrznego poprzez ocenę różnych problematycznych aspektów, wynikających w procesie przeprowadzania audytu wewnętrznego. Na przykład, Ruud (2003) sugeruje zbadać zróżnicowane zapotrzebowania organizacyjne w funkcji audytu wewnętrznego. Goodwin (2004) w swoich pracach określił główne różnice pomiędzy sektorem prywatnym i publicznym oraz rolę audytu wewnętrznego w zależności od przynależności do sektora.

Ponadto, Anderson (2003) wskazał na potrzebę identyfikacji atrybutów organizacyjnych wpływających na zdolność audytu wewnętrznego do przysparzania wartości dodanej.

Podobnie Coram i in. (2008) w swoich pracach naukowych poskreśla konieczność zbadania efektywności audytu wewnętrznego z innej perspektywy niż dotychczas dominujące postrzeganie audytorów zewnętrznych.

Hermanson i Rittenberg (2003) też podejmują pytanie istotności badania elementów mających wpływ na efektywność audytu wewnętrznego.

Rozważania na temat czynników wpływu na efektywność audytu wewnętrznego w izraelskich organizacjach podejmują Aaron Cohen i Gabriel Sayag (2010). Wyniki ich badań empirycznych doprowadziły do wniosku, że efektywność audytu wewnętrznego jest większa w sektorze prywatnym, gdzie głównym celem jest maksymalizacja zysku, co powoduje większe zainteresowanie audytem wewnętrznym przez te podmioty.

Cohen i Sayag (2010) podzielają wnioski Pfeffera i Leblebiciego (1973), w których autorzy podkreślają wpływ środowiska konkurencji na wzmocnienie instrumentów kontroli wewnętrznej w przedsiębiorstwach. Badania przeprowadzone przez Pfeffera i Leblebiciego obejmują lata 70. XX w., 
jednak późniejsze badania ustalają podobne twierdzenia. Przedmiotem dalszych badań Cohena i Sayaga było dynamiczne środowisko funkcjonowania przedsiębiorstw i ryzyka działania organizacji prywatnych, które wnosiły duże zainteresowanie rozwojem i wsparciem audytu wewnętrznego w tych organizacjach. Podobne zdanie miał Thomas, który udowadniał większą rolę audytu wewnętrznego w jednostkach prywatnych.

Cohen i Sayag (2010) określili determinanty, wpływające na efektywność audytu wewnętrznego (zob. tab. 2).

Tabela 2. Determinanty wpływające na efektywność audytu wewnętrznego

\begin{tabular}{|l|l|}
\hline \multicolumn{1}{|c|}{ Determinanty } & \multicolumn{1}{c|}{ Określenie } \\
\hline 1. Przynależność do sektora & $\begin{array}{l}\text { - prywatny } \\
\text { - publiczny }\end{array}$ \\
\hline 2. Jakość usług audytorskich & $\begin{array}{l}\text { przeprowadzenie audytu wewnętrznego zgodnie z mię- } \\
\text { dzynarodowymi standardami przekłada się na jakość } \\
\text { usług audytorskich i tym samym zwiększa efektywność } \\
\text { audytu wewnętrznego }\end{array}$ \\
\hline $\begin{array}{l}\text { 3. Profesjonalizm zespołu audy- } \\
\text { torskiego }\end{array}$ & $\begin{array}{l}\text { doświadczenie, szkolenie, umiejętności, wysokie kwa- } \\
\text { lifikacje zawodowe }\end{array}$ \\
\hline $\begin{array}{l}\text { 4. Niezależność } \\
\text { relacje pomiędzy departamentem audytu wewnętrznego } \\
\text { a Zarządem). Mautz i Sharaf (1964) określili trzy } \\
\text { wymiary niezależnóci: niezależność planowania, bada- } \\
\text { nia oraz raportowania }\end{array}$ \\
\hline $\begin{array}{l}\text { 5. Możliwości rozwoju osobistego } \\
\text { i budowanie kariery audytora } \\
\text { wewnętrznego }\end{array}$ & $\begin{array}{l}\text { dostępność audytora wewnętrznego do stanowiska } \\
\text { w zarządzie po zdobyciu należytej wiedzy i doświad- } \\
\text { czenia }\end{array}$ \\
\hline $\begin{array}{l}\text { 6. Poziom wsparcia działań audy- } \\
\text { torskich ze strony zarządu }\end{array}$ & $\begin{array}{l}\text { współpraca z kierownictwem jednostki, chęć przeka- } \\
\text { zywania informacji }\end{array}$ \\
\hline
\end{tabular}

Źródło: opracowanie własne na postawie: Cohen i Sayag (2010).

Powyższe rozważania można znaleźć w pracy naukowej Alzebana i Gwilliama (2014), którzy podkreślają wpływ jakości przeprowadzanych badań na efektywność audytu wewnętrznego. Według badania naukowego Seola, Sarkisa i Lefleya (2011) efektywność audytu wewnętrznego jest uzależniona od jakości wykonywanej pracy przez audytorów, ich umiejętności profesjonalnych i doświadczenia zawodowego.

Jak widać, w literaturze naukowej nie ma jednoznacznego stwierdzenia odnośnie do efektywności audytu wewnętrznego, jednak standaryzacja funkcjonowania i ujednolicenie głównych celów działań audytu wewnętrznego 
w przedsiębiorstwach pobudzają do rozważań na temat czynników jego efektywności.

Raport Instytutu Audytorów Wewnętrznych opublikowany w 2015 r. pokazuje od strony praktycznej różne modele efektywnego prowadzenia audytu wewnętrznego w jednostkach sektora prywatnego w Wielkiej Brytanii i Irlandii. Badanie różnych systemów organizacyjnych audytu wewnętrznego wykazało wzrost wartości dodanej organizacji, podniesienie umiejętności i kwalifikacji zawodowych audytorów. W opracowaniu zostały określone elementy efektywnego audytu wewnętrznego:

1) doskonała znajomość organizacji i specyfiki sektora, w którym funkcjonuje;

2) doświadczenie i wiedza specjalistyczna daje możliwość zwiększenia zakresu funkcji zapewniającej w dziedzinach finansów, IT, zarządzania projektami, relacji z klientami, (znajomość regulacji prawnych, przepisów krajowych i międzynarodowych, aktualnych standardów i dobrych praktyk);

3) elastyczność i zdolność szybkiego reagowania na nowe ryzyka i zagrożenia;

4) pewność i zaufanie ze strony kierownictwa;

5) niezależność i obiektywizm;

6) planowanie audytu wewnętrznego zorientowanego na ryzyko oraz przejrzysta metodologia audytu;

7) sporządzenie rekomendacji i pełnienie funkcji doradczej zorientowanej na cele organizacji;

8) wysoki poziom jakości świadczonych usług;

9) koordynacja i współpraca $z$ innymi działami, które pełnią funkcje kontrolne i zapewniające;

10) efektywna praca zespołowa;

11) możliwość rozwoju kariery;

12) ciągle podwyższenie kwalifikacji i obowiązek sumiennego wykonania zadań audytorskich.

\section{Wnioski}

Analizując podejścia różnych naukowców do określenia mierników efektywności działalności audytorów wewnętrznych można przyjąć założenie, że wskaźniki te kształtowały się wraz z ewolucją roli audytu wewnętrznego i wzrostem wymagań i oczekiwań użytkowników audytu. Rozszerzenie zakresu audytu wewnętrznego od roli stricte finansowej do funkcji 
zapewniającej i doradczej, zajmującej ważne stanowisko w systemie zarządzania przedsiębiorstwem wykazała też konieczność we wzroście efektywności usług audytorskich. Audyt wewnętrzny XXI w. powinien odpowiadać na pojawiające się problemy $\mathrm{w}$ gospodarce i nowe zagrożenia działalności, odwołując się do dorobku nauk ekonomicznych i społecznych, wykorzystując najnowsze osiągnięcia w zakresie teorii i metodologii zarządzania przy konstruowaniu audytu wewnętrznego jako nowego instrumentu zarządzania.

Problem oceny efektywności audytu wewnętrznego w przedsiębiorstwach podejmowało wielu naukowców na świecie. Powstają opracowania w zakresie poszukiwana właściwych mierników oceny efektywności audytu wewnętrznego od strony zarówno teoretycznej, jak i praktycznej.

Analiza dotychczasowych badań czynników efektywności audytu wewnętrznego w przedsiębiorstwach w różnych krajach nie wykazała wielkiego zróżnicowania w tym zakresie. Jednak brakuje jednoznacznego określenia czynników efektywności audytu wewnętrznego, co skutkuje niemożnością stworzenia podstawowego modelu efektywnego audytu wewnętrznego dla organizacji.

Przegląd literatury zagranicznej z zakresu mierników efektywności usług audytorskich jest dobrym kierunkowskazem dla przyszłej strategii badań czynników wpływających na efektywność audytu wewnętrznego w polskich przedsiębiorstwach.

\section{Bibliografia}

Al-Twaijry, A., Brierley, J. i Gwilliam, D. (2003). The development of internal audit in Saudi Arabia: an institutional theory perspective. Critical Perspectives on Accounting, 14(5), 507-531, http://dx.doi.org/10.1016/S1045-2354(02)00158-2.

Alzeban, A. i Gwilliam, D. (2014). Factors affecting the internal audit effectiveness: A survey of the Saudi public sector. Journal of International Accounting Auditing and Taxation, 23(2), 74-86, http://dx.doi.org/10.1016/j.intaccaudtax.2014.06.001.

Anderson, U. (2003). Assurance and consulting services. W: Bailey, A.D. Jr, Gramling, A.A. i Ramamoorti, S. (red.), Research Opportunities in Internal Auditing (s. 97-129). The Institute of Internal Auditors Research Foundation, Altamonte Springs, FL.

Anderson, U., Christ, M., Johnstone, K. i Rittenberg, L. (2012). A Post-SOX Examination of Factors Associated with the Size of Internal Audit Functions. Accounting Horizons, 26(2), 167-191, http://dx.doi.org/ 10.2308/acch-50115.

Barley, S.R. i Tolbert, P.S. (1997). Institutionalization and structuration: studying the linkbetween action and institution. Organization Studies, 18(1), 93-117, http://digitalcommons. ilr.cornell.edu/articles/130/.

Bou-Raad, G. (2000). Internal auditors and the value added approach: the new business regime. Managerial Auditing Journal, 15(4), 182-187, http://dx.doi.org/10.11 08/02686900010322461. 
Chapman, C., Anderson, U. (2002). Implementing the Professional Practices Framework. The Institute of Internal Auditors Research Foundation, Altamonte Springs, FL.

Charnes, A., Cooper, W. i Rhode E. (1978). Measuring the efficiency of decision making units. European Journal of Operational Research, 2(6), 429-444, http://doi:10.1016/03772217(78)90138-8.

Cohen, A. i Sayag, G. (2010). The Effectiveness of Internal Auditing: An Empirical Examination of its Determinants in Israeli Organisations. Australian Accounting Review, 54(20), 3, http://dx.doi.org/10.1111/j.1835-2561.2010.00092.x.

Coram, P., Ferguson, C. i Moroney, R. (2008). The value of internal audit in fraud detection. Accounting and Finance, 48(4), 543-559.

Drucker, P.F. (1999). Społeczeństwo pokapitalistyczne. Warszawa: PWN, s. 41.

Gasparski, W. (1983). Comments on the Concept of Efficiency. W: W. Gasparski, T. Pszczółkowski (red.), Praxicological Studies, Polish Contributions to the Science of Efficient Action (s. 69). Warszawa-Dorrdrecht-Boston-Londyn: Red. Reidel T. Publishing Company, cop. PWN.

Goodwin, J. (2004). A comparison of internal audit in the private and public sectors. Managerial Auditing Journal, 19(5), 640-650. Pozyskano z: http://search.proquest.com/docview/274693306? accountid=14887.

Hass, S., Abdolmohammadi, M.J. i Burnaby, P. (2006). The Americas literature review on internal auditing. Managerial Auditing Journal, 21(8). 835-884, http://dx.doi. org/10.1108/02686900610703778.

Hermanson, D.R. i Rittenberg, L.E. (2003). Internal audit and organizational governance. W: A.D. Bailey, Jr, A.A. Gramling i S. Ramamoorti (red.), Research Opportunities in Implications of internal audit. Internal Auditing, The Institute of Internal Auditors Research Foundation, Altamonte Springs, FL.

IIA. (2011). Definicja audytu wewnętrznego. Kodeks Etyki. Międzynarodowe Standardy praktyki zawodowej audytu wewnętrznego. Tłumaczenie na język polski. Warszawa: Stowarzyszenie Audytorów Wewnętrznych IIA Polska.

Kieżun, W. (1997). Sprawne zarządzanie organizacją. Warszawa: Szkoła Główna Handlowa.

Knechel, W.R., Rouse, P. i Schelleman, C. (2009). Modified Audit Production Framework: Evaluating the Relative Efficiency of Audit Engagement. The Accounting Review, 84(5), 1607-1638, http://dx.doi.org/ 10.2308/accr.2009.84.5.1607.

Lawrence, B., Sawyer, J.D., Dittenhofer, A. i Scheiner, J.H. (red.). (2003). Sawyer's Internal Auditing. The practice of modern internal auditing. $5^{\text {th }}$ edition, The Institute of Internal Auditors.

Lisiński, M. (red.). (2011). Audyt wewnętrzny w doskonaleniu instytucji. Warszawa: PWN.

Mautz, R., Sharaf H. (1961). The Philosophy of Auditing. American Accounting Association.

Mihret, D.G. i Yismaw, A.W. (2007). Internal audit effectiveness: an Ethiopian public sector case study. Managerial Auditing Journal, 22(5), 470-484, http://dx.doi.org/ 0.1108/02686900710750757.

Mihret, D.G., James, K. i Mula, J.M. (2010). Antecedents and organisational performance implications of internal audit effectiveness. Pacific Accounting Review, 22(3), http://dx.doi. org/ 10.1108/01140581011091684.

Moeller, R. (2015). Nowoczesny audyt wewnętrzny. Warszawa: Oficyna.

O'Keefe, T.B., Simunic, D.A. i Stein, M.T. (1994). The production of audit services: Evidence from a major public accounting firm. Journal of Accounting Research, 32(2), 241-261, http://dx.doi.org/10.2307/2491284. 
Page, M. i Spira, L. (2016). Corporate governance as custodianship of the business model. Journal of Management \& Governance, 20(2), 213-228. Pozyskano z: 10.1007/s10997016-9343-7.

Pfeffer, J. i Leblebici, H. (1973). The Effect of Competition on Some Dimensions of Organizational Structure. Social Forces, 52(2), 268-279, http://10.1093/sf/52.2.268.

Roth, J. (2002). Adding Value: Seven Roads to Success. The Institute of Internal Auditors Research Foundation, Altamonte Springs, FL.

Ruud, T.F. (2003). The internal audit function: an integral part of organizational governance. W: A.D. Bailey, Jr, A.A. Gramling i S. Ramamoorti (red.), Research Opportunities in Internal Auditing. The Institute of Internal Auditors, Altamonte Springs, FL.

Saunders, E.J. (1985). Audyt i kontrola wewnętrzna w przedsiębiorstwie. Częstochowa: PIKW SA.

Seol, I., Sarkis, J. i Lefley, F. (2011). Factor Structure of the Competency Framework for Internal Auditing (CFIA) Skills for Entering Level Internal Auditors. International Journal of Auditing, 15(3), 17-30, http://10.1111/j.1099-1123.2011.00431.x.

Simunic, D.A. (1980). The pricing of audit services: Theory and evidence. Journal of Accounting Research, 18(1), 161-190. Pozyskano z: http://www.jstor.org/stable/2490397. 


\section{Adam Czarnota*}

\section{Analiza przedsiębiorstw zaawansowanych technologii w województwie zachodniopomorskim}

Przedsiębiorstwa zaawansowanych technologii cieszą się nieustannym zainteresowaniem naukowców, publicystów i polityków gospodarczych. Jednak wyodrębnienie branży wysokich technologii jest bardzo złożonym zagadnieniem. Celem artykułu jest analiza sektora high-tech województwa zachodniopomorskiego polegająca na identyfikacji oraz charakterystyce najsilniejszych cech wyróżniających przedsiębiorstwa wysokiej techniki. W analizie zostały wykorzystane dane z bazy GUS (baza REGON), wskaźnik aktywności ZUS, uzupełnione danymi dostępnymi na stronach internetowych badanych firm.

Słowa kluczowe: wysoka technologia, klasyfikacja PKD, sektor high-tech, identyfikacja podmiotów.

\section{Analysis of High-Technology Companies in Western Pomerania}

High-Technology companies are of interest to science, industry and national authorities because of the special economic importance attached to them. However, an attempt to apply a generally accepted sectoral classification has proved to be ineffective. Study was carried out to analyze and identify the high-tech manufacturing sector to verify of the distinguishing features of this sector. Analysis was based on three sources: National Office of Statistics (GUS), Business Activity Indicator (the database run by the ZUS).

Keywords: high technology, PKD classification, high-tech sector, indentification of entities.

JEL: D2, O3

\section{Wprowadzenie}

Przedsiębiorstwom zaawansowanych technologii przypisuje się istotną rolę w kształtowaniu konkurencyjnej gospodarki, a ich znaczenie stale rośnie. W dużej mierze wynika to $\mathrm{z}$ faktu, iż często wdrażają oryginalne, przełomowe

* Adam Czarnota, mgr - Politechnika Koszalińska, Wydział Technologii i Edukacji; ul. Śniadeckich 2, 75-453 Koszalin; e-mail: adamczarnota.ieiz@gmail.com. 
rozwiązania stanowiące dzisiaj główne źródło rozwoju nie tylko dla największych gospodarek światowych i dynamicznych, dużych organizacji, lecz także dla małych i średnich przedsiębiorstw. Mówimy wręcz o nasyceniu gospodarki i społeczeństwa nowymi technologiami, które są wynikiem działań innowacyjnych firm. Działania te w głównej mierze polegają na rozpoznaniu i dopasowaniu wiedzy, którą dysponujemy do potrzeb określonych jednostek, grup i regionów.

Pomimo iż przedsiębiorstwa zaawansowanych technologii stanowią bardzo ważny obiekt badań, wyodrębnienie podmiotów należących do tego sektora jest bardzo złożonym zagadnieniem. Stąd wynika potrzeba badania tego sektora i tworzenia nowych metod i koncepcji zarządzania, dedykowanych jego specyfice. Celem artykułu jest analiza sektora high-tech województwa zachodniopomorskiego polegająca na identyfikacji oraz charakterystyce cech wskazujących na przynależność do tego sektora. W artykule wyodrębniono z ogólnej populacji zachodniopomorskich przedsiębiorstw zaawansowanych technologii wyróżniające się podgrupy oraz opracowano opis klasyfikacyjny każdej z nich. Dodatkowo celem analizy jest pokazanie, jakim potencjałem faktycznie dysponuje ten sektor w województwie, co w efekcie może zostać wykorzystane do wskazania tych firm, które warte są przeprowadzenia analiz pogłębionych.

W analizie zostały wykorzystane dane z bazy GUS (baza REGON), wskaźnik aktywności ZUS, uzupełnione danymi dostępnymi na stronach internetowych badanych firm.

\section{Specyfika przedsiębiorstw wysokich (zaawansowanych) technologii}

Przedsiębiorstwa zaawansowanych technologii cieszą się nieustannym zainteresowaniem naukowców, publicystów i polityków gospodarczych. Temu zainteresowaniu jednak nie towarzyszy dbałość o poprawność metodologiczną i jednolitą terminologię, co negatywnie wpływa na jakość prowadzonych badań oraz debaty publicznej. Trudność w definiowaniu tego sektora wynika $z$ tego, iż większość nowych technologii przekracza granice branż określanych według tradycyjnych klasyfikacji (Zakrzewska-Bielawska, 2011). W efekcie do dzisiaj nie zostały jeszcze powszechnie przyjęte żadne standardy metodologiczne, mogące ułatwić pomiar sektora wysokich technologii.

W zagranicznej literaturze przedmiotu przedsiębiorstwa zaawansowanych technologii określane są najczęściej mianem high-tech lub high-technology. 
W polskich publikacjach naukowych stosuje się dość liczne tłumaczenia tego pojęcia, np. przedsiębiorstwa: zaawansowanych technologii (Gurbała, 2007); wysokich technologii (Kozioł, 2006; Włosiński i Szerenos, 2006); wysokiej techniki (Niedbalska 2006, s. 98); oparte na nowych technologiach (Cichowski, 2005, s. 123); handlujące towarami zaawansowanymi pod względem technologicznym (Wysokińska, 2001, s. 173). Określenie „wysokie technologie”, stosowane przez Główny Urząd Statystyczny, wydaje się być zbyt bezpośrednio tłumaczone $\mathrm{z}$ języka angielskiego i tym samym niepoprawne językowo, dlatego też równie często w polskich publikacjach używa się bezpośrednio angielskiej nazwy high-tech (Ratajczak-Mrozek, 2011).

Pierwsze użycie określenia high technology przypisuje się Robertowi Metzowi - autorowi jednej z najpopularniejszych stałych rubryk w „New York Times”, która nazywała się Market Place i ukazywała się w latach 19661982, gromadząc tysiące wpływowych czytelników (Metz, 1967). Potoczne rozumienie tego terminu oznaczało te produkty oraz sektory gospodarki, które bazowały na najnowszych zdobyczach nauki i techniki. Jednak wraz z upływem lat oraz próbą systematyzacji tego obszaru gospodarki, klasyfikacja pojęciowa stała się główną osią sporu w dyskusji na temat tego, co jest, a co nie jest tzw. wysoką technologią.

Pierwszą znaną propozycję klasyfikacji opublikowała w 1980 r. Organizacja Współpracy Gospodarczej i Rozwoju², bazując na systematyce amerykańskiej i odnosząc się do handlu zagranicznego produktami wysokiej techniki (OECD, 1980). Nowa klasyfikacja opierała się na kryterium intensywności $\mathrm{B}+\mathrm{R}$ (R\&D intensity), czyli poziomu wydatków na badania i rozwój w stosunku do wartości produkcji (podejście dziedzinowe - sectoral approach). W efekcie zaowocowało to wyodrębnieniem trzech klas przemysłu w zależności od zaawansowania poziomu technologicznego (OECD, 1984):

- wysokiego (high technology),

- średniego (medium technology),

- niskiego (low technology).

Dziesięć lat później dokonano rewizji tego podejścia, rozszerzając liczbę klas do czterech:

- intensywność działalności B+R większa niż 7\%; wysoka technika,

- intensywność działalności $\mathrm{B}+\mathrm{R}$ pomiędzy 2,5 i 7\%; średnio-wysoka technika,

- intensywność działalności B+R pomiędzy 1 i 2,5\%; średnio-niska technika,

- intensywność działalności $\mathrm{B}+\mathrm{R}$ poniżej 1\%; niska technika.

2 The Organisation for Economic Co-operation and Development - OECD. 
Analizując statystykę branż względem stosowania zaawansowanych technologii, można zauważyć ciągłą ewolucję. Przykładowo, branża farmaceutyczna jeszcze w 1990 r. była klasyfikowana jako średnio-wysokiej technologii (ze wskaźnikiem 8,03\% udziału nakładów $\mathrm{B}+\mathrm{R}$ w produkcji sprzedanej), natomiast w 1999 r. udział wydatków na badania i rozwój dla tej branży okazał się być najwyższy (10,5\%) (Wojnicka, 2006). Wynika to głównie z rozwoju biotechnologii powiązanej bezpośrednio z przemysłem farmaceutycznym i będącej jednocześnie jedną z najbardziej naukochłonnych branż.

Słabością ujęcia branżowego jest fakt, że wiele wyrobów produkowanych przez firmy zaliczone do wysokiej techniki reprezentuje w rzeczywistości średnią lub niską technikę i odwrotnie. Jest to skutkiem tego, że całość nakładów na działalność $\mathrm{B}+\mathrm{R} \mathrm{w}$ danym sektorze jest przypisywana do podstawowego rodzaju działalności firm składających się na ten sektor. Konsekwencją może być przeszacowanie intensywności technologicznej $\mathrm{w}$ jednych sektorach, kosztem jej niedoszacowania w innych (Matusiak, 2011). Zdając sobie sprawę $\mathrm{z}$ wadliwości metody dziedzinowej, OECD opracowało także podejście produktowe (product approach), kwalifikujące firmy do grupy high-tech na podstawie intensywności technologicznej produkowanych przez nie wyrobów, a nie przynależności do sektora gospodarki (OECD, 1995). Do 2006 r. listy produktowe OECD były konstruowane na podstawie Międzynarodowej Standardowej Klasyfikacji Handlu (SITC Rev.3) ${ }^{3}$, a od roku 2007 dane publikowane są zgodnie z SITC Rev. 4 i obejmują kilkaset wyrobów. Pomimo iż metoda produktowa stanowi alternatywę dla dziedzinowej metody wyodrębniania branży high-tech, nie jest pozbawiona wad. Konstrukcja dokładnych list produktów wysokiej technologii jest niemożliwa bez odwołania się do ekspertyz specjalistów z danej branży, co wprowadza element arbitralności i subiektywności w ustalaniu klasyfikacji. Użycie kryteriów innych od ilościowych utrudnia także uszeregowanie produktów pod względem ich intensywności technologicznej. Stosowanie podejścia produktowego uniemożliwia również porównania $\mathrm{z}$ innymi statystykami przemysłowymi - większość z nich prowadzona jest w ujęciu sektorowym, a nie produktowym (Wojnicka, 2006).

W procesie wyodrębniania przedsiębiorstw high-tech, oprócz dwóch wyżej przedstawionych metod, proponuje się włączenie dodatkowych kryteriów - liczby uzyskanych przez firmę patentów lub podpisanych umów licencyjnych oraz udziału wysokokwalifikowanego pod względem naukowo-technicznym personelu w danym przedsiębiorstwie (Trajtenberg, 2001). Kryteria te używane są jednak raczej lokalnie niż globalnie z powodu braku

${ }^{3}$ Standard International Trade Classification, Revision 3. 
wystarczających danych, aby na ich podstawie można było dokonywać porównań międzynarodowych (Rostek i Skala, 2014).

Odmiennym podejściem jest przyjęcie tzw. definicji horyzontalnej dla sektora high-tech, która postrzega ten sektor z perspektywy nauki. Charakteryzuje się ona bardzo wysokim udziałem nakładów na badania i rozwój przy jednoczesnym zastosowaniu komercyjnym dla zupełnie nowej infrastruktury ekonomicznej. Przykładowo, zakwalifikowana jako wysoko technologiczna biotechnologia charakteryzuje się z jednej strony wysokim udziałem nakładów na $B+R$, a jednocześnie jej komercyjne zastosowania odnajdujemy w całym spektrum sektorów przemysłowych i usługowych od tradycyjnego sektora spożywczego (piekarnictwo, piwowarstwo etc.) po zaawansowaną technologicznie produkcję leków (Wojnicka, 2006). Innymi słowy metoda ta odzwierciedla istnienie wielu firm o wysokiej wiedzochłonności i intensywności badawczo-rozwojowej, które działają na rzecz branż tradycyjnych. W tym podejściu główny nacisk jest kładziony na takie technologie, jak: komunikacja, informatyka, mikroelektronika, inżynieria materiałowa czy kosmiczna (Malecki, 2000).

Retrospektywnego ujęcia sektora zaawansowanych technologii dokonuje M. Martin (2006). Zdaniem autora sektor ten jest określany i klasyfikowany także ze względu na:

- wymagania lokalowe i infrastrukturalne - standardy w tej kategorii firm high-tech w porównaniu $\mathrm{z}$ innymi sektorami są znacznie bardziej zróżnicowane i wyspecjalizowane;

- aktywność technologiczną, która dzieli przedsiębiorstwa w tym sektorze na przedsiębiorstwa zaawansowane technologicznie (high-technology firms) i przedsiębiorstwa działające w obszarze najnowszych, wiodących technologii („leading edge” high-technology firms);

- zaawansowanie technologiczne produktów i procesów, które pozwala wyróżnić produkty zaawansowane technologicznie oraz procesy zaawansowane technologicznie.

Przytoczone nomenklatury określające sektor przedsiębiorstw zaawansowanych technologii niewątpliwie ujmują szerokie spektrum omawianej problematyki, ale praktycznie uniemożliwiają wyraźne wyznaczenie grupy przedsiębiorstw, które powinny stanowić obiekt badań z tego zakresu. Stąd wynika potrzeba analizy tego sektora i tworzenia nowych metod i koncepcji zarządzania, dedykowanych jego specyfice. Szczególnym powodem przemawiającym za tą praktyką jest fakt, iż przedsiębiorstwom zaawansowanych technologii przypisuje się istotną rolę w kształtowaniu gospodarki, stanowią one jeden z podstawowych wyznaczników jej nowoczesności i konkurencyjności. Przedsiębiorstwa kwalifikujące się jako high-technology są bardzo 
cenione przez rządy nowoczesnych państw. Dzieje się tak dlatego, że firmy te wdrażają, a czasem też same produkują techniczne innowacje, wpływając tym samym na rozwój struktury przemysłowej kraju (Skala i Rostek, 2014). Nie chodzi tu tylko o wydajność samej produkcji wyrobów, lecz także o stopień wykorzystania osiągnięć zaawansowanych technologii do produkcji wyrobów tradycyjnych (Zajaczkowska-Jakimiak, 2002). Można tu zatem zaobserwować zjawisko akceleracji postępu technicznego, które polega na (Wiśniewska, 2002):

- radykalnym przyspieszeniu zmian $\mathrm{w}$ dziedzinach uznawanych za nowoczesne,

- intensywnym oddziaływaniu tych dziedzin na tradycyjne dziedziny działalności gospodarczej,

- przyspieszonej dyfuzji nowoczesnych technik w dziedzinach dotychczas przez te techniki nie penetrowanych,

- zróżnicowaniu struktury procesów technicznych, zróżnicowaniu produktów, czynników i procesów gospodarczych.

Do innych efektów dyfuzji postępu technicznego generowanego przez sektor high-tech, które wpływa na modernizację gospodarki, należy zaliczyć (Olszewski i Mozrzymas, 1997; Kudrycka, 2001; Dolińska, 1998):

- obniżkę kosztów, bowiem nowoczesne technologie pozwalają na uzyskanie tych samych efektów przy mniejszych nakładach;

- poszukiwanie nowych rozwiązań oraz wdrażanie kolejnych innowacji i wyrobów;

- wzrost efektywności, zwłaszcza kapitałowej intensywności pracy na skutek automatyzacji i robotyzacji produkcji i wprowadzenia zaawansowanych technologii informacyjnych do prac biurowych;

- zmiany w strukturze zatrudnienia sprzyjające wzrostowi wydajności pracy poprzez zmniejszenie zapotrzebowania na pracę fizyczną niewymagającą wysokich kwalifikacji.

Podsumowując, można stwierdzić, iż firmy high-tech bazujące na nowej wiedzy stanowią bardzo ważny obiekt badań, traktowany z coraz większą dociekliwością. Źródłem takiego zainteresowania jest wartość dodana, którą generują poprzez wdrażanie oryginalnych rozwiązań. Wśród determinant przedsiębiorczości technologicznej, szczególnie istotną rolę odgrywa zasób wiedzy, skuteczne działania badawczo-rozwojowe, a także szeroko pojęty kapitał intelektualny. Niestety wciąż brakuje pełnej spójności charakteryzującej ten obszar nauki. Jest to o tyle istotne, że to właśnie kompleksowe badania i teoretyczne uogólnienia powinny stanowić bazę do tworzenia polityki skutecznie wspierającej rozwój przedsiębiorstw zaawansowanych technologii. 


\section{Ogólna charakterystyka przedsiębiorstw wysokiej technologii w województwie zachodniopomorskim}

W sytuacji, gdy samo pojęcie sektora high-tech nie jest jednoznacznie definiowane $\mathrm{w}$ literaturze, a stosowane dotąd metody kwalifikowania przedsiębiorstw zaawansowanych technologii wydają się niewystarczające, istnieje potrzeba głębszej analizy w celu identyfikacji cech wskazujących na przynależność do tego sektora. W związku $\mathrm{z}$ tym podjęto badania polegające na szczegółowej charakterystyce sektora high-tech województwa zachodniopomorskiego uwzględniającej najsilniejsze cechy wyróżniające przedsiębiorstwa wysokiej techniki. Ponadto analiza zachodniopomorskiego środowiska high-tech pozwoliła określić stan faktycznego potencjału rozwojowego, jakim dysponuje badane województwo. Jest to na tyle istotne, gdyż oficjalna statystyka dotycząca populacji przedsiębiorstw należących do badanego sektora jest prawdopodobnie znacząco zawyżona.

Przeprowadzone badanie zostało podzielone na dwa etapy:

1. Analizę opisową, która została wykonana na podstawie analizy statystycznej następujących zbiorów danych:

- zbiór danych GUS (baza REGON) aktualny na maj 2016,

- wskaźnik ZUS aktualny na maj 2016.

2. Analizę stron internetowych $\mathrm{w}$ celu identyfikacji cech, które zostały zakwalifikowane jako kryteria charakteryzujące przedsiębiorstwa zaawansowanych technologii. Należą do nich:

- aktywność internetowa,

- aktywność sprzedaży,

- aktywność eksportowa,

- aktywność naukowa,

- samoocena aktywności oraz innowacyjności badanego przedsiębiorstwa.

Punktem wyjścia prowadzonych badań było wyłonienie podmiotów reprezentujących branże high-tech w województwie zachodniopomorskim. W tym celu posłużono się dziedzinową metodą wyodrębniania branży high-tech, która wyróżnia aż cztery poziomy. Należą do nich sektory:

- wysokiej techniki,

- średniowysokiej techniki,

- średnio-niskiej technologii,

- niskiej technologii. 
Kolejnym kryterium, który przyjęto był rodzaj działalności gospodarczej. W pracy skupiono się wyłącznie na przedsiębiorstwach produkcyjnych. Do wyłonienia podmiotów spełniających powyższe kryteria wykorzystano zbiór danych GUS (baza REGON) aktualny na maj 2016 r.

$\mathrm{W}$ badanym okresie $\mathrm{w}$ województwie zachodniopomorskim było zarejestrowanych i spełniających powyższe kryteria 31494 przedsiębiorstwa, w tym:

- 235 z sektora wysokiej techniki,

- 1320 z sektora średniowysokiej techniki,

- 9135 z sektora średnio-niskiej techniki,

- 20804 z sektora niskiej techniki.

Do dalszych badań zakwalifikowano 235 przedsiębiorstw z sektora wysokiej techniki, reprezentujących następujące działy:

- 21 - produkcja podstawowych substancji farmaceutycznych oraz leków i pozostałych wyrobów farmaceutycznych;

- 26 - produkcja komputerów, wyrobów elektronicznych i optycznych;

- 3030 - produkcja statków powietrznych, statków kosmicznych i podobnych maszyn.

Kolejnym etapem badania było wyeliminowanie firm nieaktywnych (tzw. martwych dusz). Powodem tego działania było założenie, że baza REGON nie odzwierciedla faktycznej aktywności przedsiębiorstw. W tym celu pozyskano dane, które pozwalały na identyfikację czynnych płatników Zakładu Ubezpieczeń Społecznych (ZUS) wśród badanej populacji. Podmioty nieodprowadzające należnych składek zostały zaklasyfikowane jako nieaktywne. Dalsza weryfikacja pozwoliła na identyfikację 168 aktywnych podmiotów. Szczegółowy ich rozkład ze względu na obszar produkcji prezentuje tabela 1 .

W grupie zachodniopomorskich firm high-tech najliczniej reprezentowany jest dział 26 - produkcji komputerów, wyrobów elektronicznych i optycznych. W tym dziale dominują następujące kategorie produkcji: 2620 (produkcja komputerów i urządzeń peryferyjnych); 2630 (produkcja sprzętu telekomunikacyjnego); 2651 (produkcja instrumentów i przyrządów pomiarowych, kontrolnych i nawigacyjnych); 2640 (produkcja elektrycznego sprzętu powszechnego użytku).

Analiza badanych podmiotów dotyczyła również rozkładu terytorialnego. Miejsce prowadzenia firmy bardzo często zależy od dostępu do informacji i wiedzy. Dla przedsiębiorstw działających w sektorach wysokiej techniki szczególnie ważne są działania instytucji naukowych, będących często źródłem innowacji, gdyż stymulują i wzmacniają prace badawczo-rozwojowe w przemyśle (Rosenberg i Nelson, 1994). Współpracując z nimi, firmy mogą 
obniżyć koszty oraz ryzyko związane z tworzeniem i wdrażaniem innowacji (Pittaway i in., 2004). Przedsiębiorstwa mogą tworzyć takie sieci wymiany z innymi firmami, instytucjami badawczo-rozwojowymi, agencjami rządowymi, uniwersytetami oraz jednostkami naukowymi.

Tabela 1. Rozkład liczności w zależności od typu produkcji

\begin{tabular}{|c|c|c|c|}
\hline PKD & Opis & Liczebność & $\begin{array}{l}\text { Udział } \\
(\mathrm{w} \%)\end{array}$ \\
\hline 2620 & Produkcja komputerów i urządzeń peryferyjnych & 41 & 24,4 \\
\hline 2630 & Produkcja sprzętu telekomunikacyjnego & 27 & 16,0 \\
\hline 2651 & $\begin{array}{l}\text { Produkcja instrumentów i przyrządów pomiaro- } \\
\text { wych, kontrolnych i nawigacyjnych }\end{array}$ & 22 & 13,1 \\
\hline 2640 & $\begin{array}{l}\text { Produkcja elektronicznego sprzętu powszechnego } \\
\text { użytku }\end{array}$ & 20 & 11,9 \\
\hline 2670 & $\begin{array}{l}\text { Produkcja instrumentów optycznych i sprzętu foto- } \\
\text { graficznego }\end{array}$ & 18 & 10,7 \\
\hline 2611 & Produkcja elementów elektronicznych & 15 & 8,9 \\
\hline 2120 & $\begin{array}{l}\text { Produkcja leków i pozostałych wyrobów farmaceu- } \\
\text { tycznych }\end{array}$ & 11 & 6,5 \\
\hline 2110 & $\begin{array}{l}\text { Produkcja podstawowych substancji farmaceutycz- } \\
\text { nych }\end{array}$ & 5 & 3,0 \\
\hline 2660 & $\begin{array}{l}\text { Produkcja urządzeń napromieniowujących, sprzętu } \\
\text { elektromedycznego i elektroterapeutycznego }\end{array}$ & 4 & 2,4 \\
\hline 2612 & Produkcja elektronicznych obwodów drukowanych & 3 & 1,9 \\
\hline 2652 & Produkcja zegarków i zegarów & 1 & 0,6 \\
\hline 3030 & $\begin{array}{l}\text { Produkcja statków powietrznych, statków kosmicz- } \\
\text { nych i podobnych maszyn }\end{array}$ & 1 & 0,6 \\
\hline SUMA & & 168 & 100,0 \\
\hline
\end{tabular}

Źródło: opracowanie własne.

Analiza terytorialna została ograniczona do wielkości miejscowości wyrażonej liczbą mieszkańców. Przy założeniu, że to w dużych miastach znajdują się główne ośrodki naukowe, może mieć to wpływ na prowadzenie działalności właśnie w tych miejscach. Wyniki analizy przedstawia tabela 2. 
Tabela 2. Rozkład badanych podmiotów w zależności od lokalizacji

\begin{tabular}{|l|c|c|}
\hline \multicolumn{1}{|c|}{ Liczba mieszkańców } & Liczba firm & Udział (w \%) \\
\hline Powyżej 100000 & 102 & 60,70 \\
\hline Od 50000 do 99999 & 2 & 1,20 \\
\hline Od 10000 do 49999 & 43 & 25,60 \\
\hline Do 10000 & 21 & 12,45 \\
\hline SUMA & 168 & 100,00 \\
\hline
\end{tabular}

Źródło: opracowanie własne.

Ponad $60 \%$ badanych przedsiębiorstw zarejestrowanych jest w dwóch największych miastach województwa zachodniopomorskiego - Szczecinie oraz Koszalinie. Miasta te stanowią główne ośrodki naukowe w regionie (Czarnota, 2013). Dwa przedsiębiorstwa zlokalizowane są w Stargardzie. Jest to jedyne miasto w województwie z przedziału od 50000 do 99999 mieszkańców. Osiągnięte wyniki wskazują, iż warto przeprowadzić badania pogłębione w celu odpowiedzi na pytanie: w jakim stopniu położenie geograficzne wpływa na działalność (w tym innowacyjną) firm sektora high-tech.

Analiza wielkości przedsiębiorstw została przeprowadzona w oparciu o wielkość zatrudnienia. Należy jednak podkreślić, że jest to liczba pracowników zgłoszona przez przedsiębiorcę w momencie rejestracji firmy. W przypadku firm zatrudniających do 9 pracowników może nie być nigdy potem uaktualniona. Wyniki prezentuje tabela 3.

Tabela 3. Rozkład liczebności zatrudnienia

\begin{tabular}{|l|c|c|}
\hline \multicolumn{1}{|c|}{ Liczba zatrudnionych } & Liczebność & Udział (w \%) \\
\hline $0-9$ & 148 & 88,1 \\
\hline $10-49$ & 12 & 7,1 \\
\hline $50-249$ & 6 & 3,6 \\
\hline $250-999$ & 2 & 1,2 \\
\hline SUMA & 168 & 100,0 \\
\hline
\end{tabular}

Źródło: opracowanie własne.

Tylko 1,2\% przedsiębiorstw zatrudnia co najmniej 250 osób. Blisko 99\% należy do MSP, a w tym aż $88,1 \%$ to przedsiębiorstwa mikro zatrudniające do 9 osób. Można stwierdzić, że tak zawężona badana 
populacja jest bliska typowej strukturze zatrudnienia dla wszystkich polskich przedsiębiorstw ${ }^{4}$.

Forma prawna przedsiębiorstwa jest określana przez podstawową oraz szczególną formę prawną. W grupie badanych firm rozkład wartości podstawowej formy prawnej prezentuje tabela 4 .

Tabela 4. Rozkład liczebności podstawowej formy prawnej

\begin{tabular}{|c|l|c|c|}
\hline $\begin{array}{c}\text { Podstawowa } \\
\text { forma prawna }\end{array}$ & \multicolumn{1}{|c|}{ Opis } & Liczebność & Udział (w \%) \\
\hline 9 & $\begin{array}{l}\text { osoba fizyczna prowadząca } \\
\text { działalność gospodarczą }\end{array}$ & 98 & 58,4 \\
\hline 1 & osoba prawna & 55 & 32,7 \\
\hline 2 & $\begin{array}{l}\text { jednostka organizacyjna niemająca } \\
\text { osobowości prawnej }\end{array}$ & 15 & 8,9 \\
\hline SUMA & & 168 & 100,0 \\
\hline
\end{tabular}

Źródło: opracowanie własne.

Uzupełnieniem podstawowej formy prawnej jest analiza szczególnej formy prawnej FP, prezentowana w tabeli 5.

Tabela 5. Rozkład liczebności szczególnej formy prawnej

\begin{tabular}{|c|l|c|c|}
\hline $\begin{array}{c}\text { Szczególna } \\
\text { forma prawna }\end{array}$ & \multicolumn{1}{|c|}{ Opis } & Liczebność & Udział (w \%) \\
\hline 99 & bez szczególnej formy prawnej & 98 & 58,3 \\
\hline 17 & $\begin{array}{l}\text { spółki z ograniczoną odpowiedzial- } \\
\text { nością }\end{array}$ & 54 & 32,1 \\
\hline 19 & spółki cywilne & 9 & 5,4 \\
\hline 20 & spółki komandytowe & 4 & 2,4 \\
\hline 18 & spółki jawne & 2 & 1,2 \\
\hline 21 & spółki komandytowo-akcyjne & 1 & 0,6 \\
\hline SUMA & & 168 & 100,0 \\
\hline
\end{tabular}

Źródło: opracowanie własne.

${ }^{4}$ W 2014 r. struktura aktywnych przedsiębiorstw pod względem zatrudnienia prezentowała się następująco: 0-9 zatrudnionych - 95,8\%, 10-49 zatrudnionych - 3,2\%, 50-249 zatrudnionych - 0,8\%, powyżej 250 zatrudnionych - 0,2\% (zob. GUS, 2015). 
Wśród zachodniopomorskich przedsiębiorstw zaawansowanej technologii dominuje forma osoby prawnej oraz fizycznej. Są to przede wszystkim podmioty bez szczególnej formy prawnej, spółki z ograniczoną odpowiedzialnością oraz spółki cywilne. Grupa firm poddanych badaniu składa się $\mathrm{w}$ większości $\mathrm{z}$ podmiotów stanowiących jednoosobową działalność gospodarczą. Takie firmy są przykładami najmniejszych podmiotów. Firmy posiadające przeważnie większą strukturę to spółki z ograniczoną odpowiedzialnością.

W każdym z sektorów jest określony stopień „posiadania” przez podmiot kapitału. W przypadku własności wyróżnić można własność czystą, czyli posiadanie 100\% kapitału przez jeden podmiot lub podmioty, które reprezentują ten sam rodzaj własności oraz własność mieszaną, czyli podział majątku na dwa lub więcej podmiotów reprezentujące różny poziom własności (Dębski, 2006). Zidentyfikowane formy własności badanych firm prezentuje tabela 6 .

Tabela 6. Rozkład liczebności poszczególnych form własności

\begin{tabular}{|c|c|c|c|}
\hline $\begin{array}{c}\text { Forma } \\
\text { własności }\end{array}$ & Opis & Liczebność & Udział (w \%) \\
\hline 214 & własność krajowych osób fizycznych & 131 & 76,7 \\
\hline 215 & własność prywatna krajowa pozostała & 12 & 7,1 \\
\hline 216 & własność osób zagranicznych & 11 & 6,5 \\
\hline 224 & $\begin{array}{l}\text { własność mieszana w sektorze prywat- } \\
\text { nym z przewagą własności krajowych } \\
\text { osób fizycznych }\end{array}$ & 5 & 2,9 \\
\hline 226 & $\begin{array}{l}\text { własność mieszana w sektorze prywat- } \\
\text { nym z przewagą własności zagranicznej }\end{array}$ & 4 & 2,3 \\
\hline 225 & $\begin{array}{l}\text { własność mieszana w sektorze prywat- } \\
\text { nym z przewagą własności prywatnej } \\
\text { krajowej pozostałej }\end{array}$ & 3 & 1,7 \\
\hline 227 & $\begin{array}{l}\text { własność mieszana w sektorze prywat- } \\
\text { nym z brakiem przewagi któregokolwiek } \\
\text { rodzaju własności prywatnej }\end{array}$ & 2 & 1,2 \\
\hline 133 & $\begin{array}{l}\text { własność mieszana między sektorami } \\
\text { z przewagą sektora }\end{array}$ & 1 & 0,8 \\
\hline 234 & $\begin{array}{l}\text { własność mieszana między sektorami } \\
\text { z przewagą własności sektora prywat- } \\
\text { nego, w tym z przewagą własności kra- } \\
\text { jowych osób fizycznych }\end{array}$ & 1 & 0,8 \\
\hline SUMA & & 168 & 100,0 \\
\hline
\end{tabular}

Źródło: opracowanie własne. 
Z badania wynika, że blisko 77\% przedsiębiorstw jest własnością prywatną osób fizycznych pochodzenia krajowego.

Na tym etapie można stwierdzić, iż statystyczny profil przedsiębiorstwa występującego najczęściej posiada następujące cechy:

- klasyfikowany w dziale PDK 26 - produkcji komputerów, wyrobów elektronicznych i optycznych;

- zlokalizowany w największych miastach województwa zachodniopomorskiego (Szczecin, Koszalin);

- będący mikroprzedsiębiorstwem zatrudniającym do 9 osób;

- o podstawowej formie prawnej lub fizycznej prowadzącej działalność gospodarczą;

- o szczególnej formie podmiotu bez szczególnej formy prawnej, spółki z ograniczoną odpowiedzialnością lub spółki cywilnej;

- będący formą własności krajowej.

\section{Analiza cech wyróżniających przedsiębiorstwa wysokiej technologii w województwie zachodniopomorskim}

W dalszej części badania przyjęto, że nowoczesna firma high-tech powinna dysponować własną stroną www. Odnalezione strony internetowe wybranych firm poddano badaniu jakościowemu, które polegało na przejrzeniu ich zawartości (Jemielniak, 2012). W tym celu zastosowano metodę clippingu. Clipping (press clipping) jest to metoda pomiaru efektywności działań public relations. Polega na analizie wszelkich informacji, komunikatów, jakie pojawiają się w mediach na temat danej firmy ${ }^{5}$. Pierwszym etapem zastosowania tej metody była weryfikacja, które $\mathrm{z}$ badanych przedsiębiorstw posiadają strony internetowe, gdyż to często świadczy o ukierunkowaniu na nowoczesne technologie oraz innowacyjność rozwiązań (Skala, 2014). Rozkład liczności posiadaczy stron internetowych przedstawia tabela 7.

Zweryfikowaną stronę internetową posiada 68 przedsiębiorstw co stanowi blisko $41 \%$ badanych podmiotów. Jednak na tym etapie samo jej posiadanie nie gwarantowało firmie przejścia do dalszej analizy. Początkowe przejrzenie zawartości stron polegało na porównaniu faktycznego rodzaju prowadzonej

5 Pozyskano z: http://www.newsline.pl/naukapublicrelations/slownikpojec/art14.html (01.07.2016). 
działalności z tym wskazanym jako wiodący podczas rejestracji firmy. Efektem tego zabiegu była eliminacja przedsiębiorstw niespełniających kryterium przynależności do sektora high-tech. Postanowiono więc odrzucić firmy, których produkty nie były zgodne z przyjętą klasyfikacją określającą poziom zaawansowania technologicznego. Do dalszej analizy zakwalifikowano jednak firmy, których produkty nie były zgodne z kodem $\mathrm{PKD}^{6}$ wskazanym jako wiodący, a nadal charakteryzowały się najwyższym poziomem technologicznym. Do kolejnego etapu badań przyjęto 62 przedsiębiorstwa.

Tabela 7. Rozkład liczebności stron internetowych

\begin{tabular}{|l|c|c|}
\hline \multicolumn{1}{|c|}{ Czy firma posiada stronę www? } & Liczebność & Udział (w \%) \\
\hline Tak & 68 & 40,5 \\
\hline Nie & 100 & 59,5 \\
\hline SUMA & 168 & 100,0 \\
\hline
\end{tabular}

Źródło: opracowanie własne.

O aktywności internetowej świadczy również posiadanie strony WWW w języku obcym. Jest to dowód o potencjalnej internacjonalizacji działalności. Jak dowodzą badania dla przedsiębiorstw zaawansowanych technologii internacjonalizacja często nie jest kwestią wyboru, lecz koniecznością z racji ograniczonego popytu krajowego. Ponadto to właśnie te firmy stanowią najczęstszy przykład przedsiębiorstw typu born global czy urodzonych globalistów, podmiotów, które od momentu powstania czerpią przewagę konkurencyjną z wykorzystania zasobów i sprzedaży w wielu krajach (Oviatt i McDougall, 1994). Rozkład liczebności posiadania strony internetowej w języku obcym przedstawia tabela 8 .

Tabela 8. Rozkład liczebności posiadania strony internetowej w języku obcym

\begin{tabular}{|l|c|c|}
\hline \multicolumn{1}{|c|}{$\begin{array}{c}\text { Czy firma posiada stronę www } \\
\text { w języku obcym }\end{array}$} & Liczebność & Udział (w \%) \\
\hline Tak & 24 & 38,8 \\
\hline Nie & 38 & 61,2 \\
\hline SUMA & 62 & 100,0 \\
\hline
\end{tabular}

Źródło: opracowanie własne.

${ }^{6}$ Polska Klasyfikacja Działalności. 
Obcojęzyczna strona występuje wśród 39\% posiadaczy strony internetowej, przy czym najczęściej wybieranym językiem tłumaczenia był język angielski.

O ile posiadanie strony internetowej w języku obcym świadczy jedynie o potencjalnej internacjonalizacji, o tyle w niektórych przypadkach można było zauważyć deklarację przedsiębiorstwa o działalności eksportowej. W świetle prowadzonych badań (Mińska-Struzik, 2013) ten właśnie czynnik intensywnie stymuluje rozwój przedsiębiorstw high-tech, poprzez kreowanie potrzeby i możliwości w zakresie technologicznego uczenia się. Liczbę firm informujących o eksporcie przedstawia tabela 9.

Tabela 9. Rozkład liczebności firm deklarujących działalność eksportową

\begin{tabular}{|l|c|c|}
\hline \multicolumn{1}{|c|}{$\begin{array}{c}\text { Czy firma deklaruje aktywność } \\
\text { eksportową? }\end{array}$} & Liczebność & Udzial (w \%) \\
\hline Tak & 49 & 79 \\
\hline Nie & 13 & 21 \\
\hline SUMA & 62 & 100 \\
\hline
\end{tabular}

Źródło: opracowanie własne.

Jak wynika z danych, aż 79\% badanych firm deklaruje działalność eksportową. Kolejnym krokiem analizy było określenie rodzaju aktywności sprzedaży w odniesieniu do sprzedaży typu $\mathrm{B} 2 \mathrm{~B}^{7}$ oraz $\mathrm{B} 2 \mathrm{C}^{8}$. Wyniki w tym zakresie prezentują tabele 10-11.

Tabela 10. Liczebność firm świadczących sprzedaż B2B

\begin{tabular}{|l|c|c|}
\hline \multicolumn{1}{|c|}{ Czy firma świadczy sprzedaż B2B? } & Liczebność & Udział (w \%) \\
\hline Tak & 30 & 48,4 \\
\hline Nie & 32 & 51,6 \\
\hline SUMA & 62 & 100,0 \\
\hline
\end{tabular}

Źródło: opracowanie własne.

7 B2B (business-to-business) - skrót pochodzący z języka angielskiego oznaczający transakcje pomiędzy dwoma lub więcej podmiotami gospodarczymi (zob. Wankel, 2009, s. 200).

${ }^{8}$ B2C (business-to-consumer) - nazwa relacji występujących pomiędzy firmą a klientem końcowym (zob. Słowniczek branżowy na stronie: https://undicom.pl/strony_www_slowniczek_branzowy.html (01.07.2016)). 
Tabela 11. Liczebność firm świadczących sprzedaż B2C

\begin{tabular}{|l|c|c|}
\hline \multicolumn{1}{|c|}{ Czy firma świadczy sprzedaż B2C? } & Liczebność & Udział (w \%) \\
\hline Tak & 45 & 72,6 \\
\hline Nie & 17 & 27,4 \\
\hline SUMA & 62 & 100,0 \\
\hline
\end{tabular}

Źródło: opracowanie własne.

Wśród badanych przedsiębiorstw najpopularniejszą formą sprzedaży jest sprzedaż B2C, którą deklaruje blisko 73\% firm, natomiast sprzedaż B2B występuje u prawie połowy podmiotów.

W analizie stron internetowych na szczególną uwagę zasługuje analiza aktywności naukowej wyrażona informacją o posiadaniu patentu, certyfikatów, a także informacją o współpracy z ośrodkami naukowymi i badawczymi. Jak już zostało wspomniane w rozdziale 2, posiadane patenty oraz certyfikaty mogą wskazywać na działalność innowacyjną, natomiast współpraca pomiędzy przedstawicielami nauki a przedsiębiorstwami high-tech nierzadko przekłada się na wzrost efektywności w obszarze $\mathrm{B}+\mathrm{R}$ (Łukaszek-Rozpendowska, 2009). Wyniki w tym zakresie prezentują tabele 12-14.

Tabela 12. Liczebność podmiotów posiadających patenty

\begin{tabular}{|l|c|c|}
\hline \multicolumn{1}{|c|}{ Czy firma posiada własne patenty? } & Liczebność & Udział (w \%) \\
\hline Tak & 5 & 8 \\
\hline Nie & 57 & 92 \\
\hline SUMA & 62 & 100 \\
\hline
\end{tabular}

Źródło: opracowanie własne.

Tabela 13. Liczebność podmiotów posiadających certyfikaty

\begin{tabular}{|l|c|c|}
\hline \multicolumn{1}{|c|}{ Czy firma posiada certyfikaty? } & Liczebność & Udział (w \%) \\
\hline Tak & 15 & 24,2 \\
\hline Nie & 47 & 75,8 \\
\hline SUMA & 62 & 100,0 \\
\hline
\end{tabular}

Źródło: opracowanie własne. 
Tabela 14. Liczebność podmiotów współpracujących z ośrodkami naukowymi

\begin{tabular}{|l|c|c|}
\hline \multicolumn{1}{|c|}{$\begin{array}{c}\text { Czy firma współpracuje } \mathbf{z} \text { ośrodkami } \\
\text { naukowymi i badawczymi }\end{array}$} & Liczebność & Udział (w \%) \\
\hline Tak & 9 & 14,5 \\
\hline Nie & 53 & 85,5 \\
\hline SUMA & 62 & 100,0 \\
\hline
\end{tabular}

Źródło: opracowanie własne.

Z badań wynika, iż liczba przedsiębiorstw deklarujących posiadanie patentów to zaledwie $8 \%$ całej grupy. Znacznie lepiej wygląda sytuacja z certyfikatami. Posiadanie ich deklaruje blisko co czwarte przedsiębiorstwo. Skłonność do współpracy pomiędzy sferą badawczo-rozwojową a przedsiębiorstwami deklaruje jedynie $14,5 \%$. Tak mały odsetek potwierdza ogólnopolską tendencję. Zdaniem badaczy w głównej mierze decyduje o tym zarówno niska przydatność dorobku naukowego dla praktyki gospodarczej, jak i brak świadomości przedsiębiorstw o możliwościach takiej współpracy (Matusiak i Guliński, 2010; Makowiec i Kusio, 2010).

$\mathrm{Na}$ koniec badania przeanalizowano samoocenę aktywności innowacyjnej przedsiębiorstwa. Taka informacja miała wskazać stopień, w jakim dana firma określa się mianem innowacyjnej. Wyniki przedstawia tabela 15 .

Tabela 15. Liczebność podmiotów oceniających się jako innowacyjne

\begin{tabular}{|l|c|c|}
\hline \multicolumn{1}{|c|}{$\begin{array}{c}\text { Czy firma deklaruje własną aktywność } \\
\text { innowacyjną }\end{array}$} & Liczebność & Udział (w \%) \\
\hline Tak & 11 & 17,7 \\
\hline Nie & 51 & 82,3 \\
\hline SUMA & 62 & 100,0 \\
\hline
\end{tabular}

Źródło: opracowanie własne.

Biorąc pod uwagę analizę cech wyróżniających zachodniopomorskie przedsiębiorstwa high-tech, przeprowadzoną na podstawie informacji dostępnych na ich stronach internetowych, należy zauważyć, że są to podmioty, które:

- posiadają polskojęzyczne strony internetowe,

- tylko w 39\% przypadków zamieszczają wersję obcojęzyczną strony,

- są obecne na rynkach międzynarodowych,

- preferują sprzedaż typu B2C, 
- posiadają certyfikaty, ale rzadko zdarza się, żeby współpracowali z ośrodkami naukowymi lub posiadali własne patenty,

- niedostatecznie dobrze oceniają swoją innowacyjność.

\section{Podsumowanie}

W trakcie badań nad populacją podmiotów gospodarczych zarejestrowanych w województwie zachodniopomorskim podjęto się analizy tych, które można zakwalifikować jako przedsiębiorstwa wysokiej technologii. W tym celu dokonano charakterystyki opisowej, a następnie uszczegóławiającej charakterystyki cech wyróżniających ten sektor. Z uwagi na ewolucję klasyfikacji podmiotów należących do branży high-tech, badania rozpoczęto od wyodrębnienia firm spełniających kryteria odpowiedniego poziomu zaawansowania technologicznego. Analiza została opracowana na podstawie danych GUS, a następnie uzupełniona o analizę danych pozyskanych ze stron internetowych. Statystycznie zachodniopomorskie przedsiębiorstwa high-tech to mikroprzedsiębiorstwa zajmujące się głównie produkcją komputerów, wyrobów elektronicznych lub optycznych. Posiadają osobowość prawną lub fizyczną i prowadzą działalność gospodarczą $\mathrm{w}$ formule: bez szczególnej formy prawnej lub spółki z o.o. Swoją działalność gospodarczą zarejestrowaną mają w dużych miastach liczących powyżej stu tysięcy mieszkańców. Są to przedsiębiorstwa o dominującej formie własności krajowej.

Analiza stron internetowych wskazała na to, iż 91\% badanych przedsiębiorstw faktycznie działa w sektorze wskazanym jako wiodący przy rejestracji działalności gospodarczej. Można jednak stwierdzić, że ich aktywność internetowa plasuje się na umiarkowanym poziomie. Tylko $41 \%$ aktywnych przedsiębiorstw posiada stronę internetową, głównie w języku polskim. Posiadanie obcojęzycznej strony internetowej nie jest skorelowane $\mathrm{z}$ deklarowaną działalnością eksportową, gdyż na 39\% firm posiadających strony, w obcym języku aż 79\% deklaruje sprzedaż produktów poza granicami kraju. Badane przedsiębiorstwa głównie preferują sprzedaż B2C, co wskazywało by jednak na potrzebę rozwoju kanału komunikacyjnego, jakim jest sieć internetowa. Posiadają certyfikaty, lecz rzadko współpracują z ośrodkami naukowymi. W dodatku bardzo mała liczba firm posiada własne patenty. Słaby wynik aktywności naukowej przekłada się na niską samooceną w kategorii innowacyjności.

Pomimo iż w ogólnym zestawieniu zachodniopomorskie przedsiębiorstwa zaawansowanej technologii nie odstępują od ogólnopolskiej charakterystyki, to jednak można wyodrębnić podgrupy, które wyróżniają się ponad 
przeciętną aktywnością na rynkach międzynarodowych, aktywnością naukową oraz szybkim rozwojem. W celu zidentyfikowania pełniejszych prawidłowości i tendencji występujących $\mathrm{w}$ tej grupie warto byłoby przeprowadzić badania pogłębione, szczególnie w obszarze aktywności innowacyjnej oraz eksportowej. W opinii autora niniejszej pracy, właśnie badania prowadzone $\mathrm{w}$ obszarze przedsiębiorstw zaawansowanych technologii, jako wiodących jednostek produkcyjnych, mogą mieć istotne znaczenie dla wskazania najlepszego kierunku rozwoju gospodarki kraju.

\section{Bibliografia}

Czarnota, A. (2013). Kierunki rozwoju edukacji w zakresie przedsiębiorczości w szkołach wyższych województwa zachodniopomorskiego. W: J.E. Wasilczuk (red.), Przedsiębiorczość w ośmiu odsłonach, Gdańsk: Wydawnictwo Politechniki Gdańskiej.

Dębski, D. (2006). Ekonomika i organizacja przedsiębiorstw. Warszawa: WSiP, s. 32.

Dolińska, M. (1998). Technologie informacyjne w logistyce rynkowej. Przegląd Organizacji, $1,35-38$.

Gurbała, M. (2007). Przemysł zaawansowanej technologii w Polsce. Kwartalnik Nauk o Przedsiębiorstwie, 3 .

GUS. (2015). Działalność przedsiębiorstw niefinansowych w 2014 r. Warszawa: GUS.

Jemielniak, D. (2012). Czym są badania jakościowe? W: D. Jemielniak (red.), Badania jakościowe (t. 1: Podejścia i teorie). Warszawa: Wydawnictwo PWN.

Kozioł, K. (2006). Cele i bariery działalności innowacyjnej polskich przedsiębiorstw wysokiej technologii. Przegląd Organizacji, 5.

Kudrycka, I. (2001). Wpływ nowoczesnych technik wytwarzania na zmiany struktury w polskiej gospodarce. W: J. Hołubiec (red.), Współczesne problemy zarządzania. Warszawa: Wyższa Szkoła Informatyki Stosowanej i Zarządzania.

Łukaszek-Rozpendowska, D. (2009). Konkurencyjność sektora wysokiej techniki. Departament Analiz i Prognoz. Warszawa: Ministerstwo Gospodarki, s. 32.

Makowiec, M. i Kusio, T. (2010). Współpraca nauki i biznesu w kontekście komercjalizacji wyników badań naukowych - wymiar krajowy i międzynarodowy. W: J. Teczke, J. Czekaj (red.), Zarządzanie intensyfikujące rozwój gospodarczy (t. 2, s. 59-83). Kraków: Wydawnictwo ESUS Druk.

Malecki, E.J. (2000). Network Models for Technology Based Growth. W: Z. Acs (red.), Regional Innovation, Knowledge and Global. London and New York: Change, Pinter.

Martin, M. (2006), Charakterystyka pojęcia wysokich technologii - ujęcie retrospektywne. Zeszyty Naukowe Politechniki Łódzkiej, seria: Organizacja i Zarządzanie, Nr 42, Łódź, 73-84.

Matusiak, K. i Guliński, J. (red.). (2010). System transferu technologii i komercjalizacji w Polsce - sity motoryczne i bariery. Warszawa: PARP.

Matusiak, K.B. (2011). Wysoka Technika. W: K.B. Matusiak (red.), Innowacje i transfer technologii. Słownik pojęć (wyd. 3) (s. 328-331). Warszawa: Polska Agencja Rozwoju Przedsiębiorczości.

Metz, R. (1967). Market Place: Conglomerates Yield Surprises. New York Times, Section Business \& Finance, 16 czerwca, F62. Pozyskano z: http://select.nytimes.com/gst/. 
Mińska-Struzik, E. (2013). Znaczenie eksportu w działalności innowacyjnej polskich przedsiębiorstw wysokiej techniki. Warszawa: IX Kongres Ekonomistów Polskich.

Niedbalska, G. i in. (1999). Definicje pojęć z zakresu statystyki nauki i techniki. Warszawa: Główny Urząd Statystyczny, s. 98.

OECD. (1980). International trade in high research and development-intensive products. SITC/80.48. Paris: OECD.

OECD. (1984). Specialisation and competitiveness in high, medium and low R\&D-intensity manufacturing industries: general trends. DSTI/SPR/84-49. Paris: OECD.

OECD. (1995). Classification of High-technology Products and Industries. DSTI/EAS/IND/ STP(95)1. Paris: OECD.

Olszewski, L. i Mozrzymas, J. (1997). Struktury przemysłowe w gospodarce. Aspekty ekonomiczne, społeczno-kulturowe i polityczne. Wrocław: Wydawnictwo Uniwersytetu Wrocławskiego, s. 12.

Oviatt, B.M. i McDougall, P.P. (1994). Towards a Theory of International New Ventures. Journal of International Business Studies, 25(1), 49.

Pittaway, L., Robertson, M., Munir, K. i Denyer, D. (2004). Networking and innovation: A systematic review of the evidence. Lancaster University Management School, Working Paper 2004/016.

Ratajczak-Mrozek, M. (2011). Specyfika przedsiębiorstw zaawansowanych technologii (high-tech). Przegląd Organizacji, 2, 26.

Rosenberg, N. i Nelson, R.R. (1994). American universities and technical advance in industry. Research Policy, 23, 323-348.

Rostek, K. i Skala, A. (2014). Warszawskie Przedsiębiorstwa Wysokiej Techniki. Raport analityczny. Społeczne Forum Przedsiębiorczości, Warszawa, 4.

Skala, A, (2014). Nowa metoda identyfikacji przedsiębiorstw wysokiej technologii na przykładzie Warszawy. Modern Management Review, XIX, 21(2), 115.

Trajtenberg, M. (2001). Innovation in Israel 1968-1997: a comparative analysis using patent data. Research Policy, 30(3), 363-389.

https://undicom.pl/strony_www_slowniczek_branzowy.html.

Wankel, Ch. (red.). (2009). Encyclopedia of Business in Today's World (vol. 1.) Thousand Oaks: SAGE, s. 200

Wiśniewska, J. (2002). Rola procesów dyfuzji rynkowej innowacji. W: Modele, kapitał i miary efektywności przedsiębiorstw, Zeszyty Naukowe, Nr 329. Prace Instytutu Ekonomiki i Organizacji Przedsiębiorstw, nr 40 (s. 49). Szczecin: WN Uniwersytetu Szczecińskiego.

Włosinski, K. i Szerenos, A.M. (2006). Klastry wysokotechnologiczne na Mazowszu - wyniki badań. Organizacja i Kierowanie, 3.

Wojnicka, E. (red.). (2006). Perspektywy rozwoju małych i średnich przedsiębiorstw wysokich technologii w Polsce do 2020 roku. Warszawa: PARP, s. 7.

Wysokińska, Z. (2001). Konkurencyjność w międzynarodowym i globalnym handlu technologiami. Warszawa, Łódź: Wydawnictwo Naukowe PWN, s. 173.

Zajaczkowska-Jakimiak, S. (2002). Wiedza i technologia w erze globalizacji. W: B. Liberska (red.). Globalizacja, mechanizmy i wyzwania (s. 95). Warszawa: PWE.

Zakrzewska-Bielawska, A. (red.). (2011). Relacje między strategią a strukturą organizacyjną w przedsiębiorstwach wysokich technologii. Zeszyty naukowe, Nr 1095. Łódź, s. 20. 


\section{Joanna Chlebiej*}

\section{Wizerunek branży farmaceutycznej w polskim Internecie}

Wizerunek jest czymś, co zazwyczaj przesądza o sukcesie marki lub organizacji. Są jednak specyficzne branże, jak np. farmaceutyczna, w których każda pojawiająca się publicznie informacja przekłada się na wizerunek całego sektora. Wynika to z tego, że przeciętny konsument nie zna konkretnych koncernów produkujących leki, kieruje się natomiast pewnymi ogólnymi stereotypami. Docierające do niego informacje medialne dotyczące farmaceutyków tylko wzmacniają pewne przekonania, jednak zazwyczaj są to przekonania dotyczące producentów leków w ogóle, a nie tylko konkretnego wytwórcy. Przeciętnego konsumenta mniej bowiem interesuje kto wymyśli lek na raka, ale ważne będzie, że w ogóle lek taki zostanie wynaleziony. Mniej istotne będzie także kto przekupuje lekarzy i że w ogóle kogoś reprezentującego zawód zaufania publicznego da się przekupić. Zasługi i przewinienia reprezentantów branży są bowiem tak istotne dla społeczeństwa, że mogą przysłaniać wszelkie inne informacje zasłyszane w danym momencie. Dlatego też na potrzeby poniższego artykułu, autorka skupiła się na wizerunku całej branży, a nie pojedynczych podmiotów na nim działających.

Słowa kluczowe: wizerunek, branża farmaceutyczna, prawo farmaceutyczne.

\section{Image of the Pharmaceutical Industry on the Polish Internet}

Image is something that usually determines the success of your brand or organization. However, there are industries such as the pharmaceutical industry described in this article. This is a very specific discipline where all public information translates into the image of the entire industry. This results from the fact an average consumer does not know specific drug-producing concerns, but is guided by certain stereotypes about the industry as a whole. General media information about pharmaceuticals only reinforces certain beliefs, but usually these are the beliefs about drug manufacturers in general and not just a specific manufacturer. An average consumer is less interested in who invents a drug for cancer, but it is important that the drug is invented at all. It will also be less important to the person who bribes doctors that someone of public trust can be bribed

* Joanna Chlebiej, mgr - Uniwersytet Warszawski, Wydział Zarządzania; ul. Szturmowa 1/3, 02-678 Warszawa; e-mail: joannachlebiej@wp.pl. 
at all. The merits and conduct of industry representatives are so important to society that they can obscure any other information heard at a given moment. Therefore, for the purpose of the article below, the author focused on the image of the entire industry, not on the individual entities operating in it.

Keywords: image, Pharmaceutical industry, pharmaceutical law.

JEL: K49, K32, M14, M37, M38

\section{Wprowadzenie}

Zagadnienie wpływu prawa na wizerunek branży farmaceutycznej może być istotnym problemem z punktu widzenia nauki o marketingu. Jest to temat o tyle ważny, że przemysł farmaceutyczny ma istotny wpływ na zdrowie i życie ludzkie oraz na kształtowanie się wydatków z budżetu domowego obywateli. Ponadto, samo zarządzanie tego typu instytucjami od dłuższego już czasu nurtuje naukowców. Jednak do tej pory problemy zarządzania występujące w branży farmaceutycznej stanowią tajemnicę. Dla samych praktyków zagadnienie wizerunku w branży farmaceutycznej jest również trudnym tematem, gdyż branża ta narażona jest na wiele poważnych, różnorodnych rodzajów ryzyka związanych ze swoją działalnością. Korupcja, działania niepożądane mogące mieć wpływ na ludzkie zdrowie i życie, przemyt, wyciek danych osobowych, niezgodna z prawem reklama to najpoważniejsze, ale nieliczne z rodzajów ryzyka, jakie mogą wystąpić w tego typu przedsiębiorstwach. Jest to bowiem branża wymagająca szerokiego zakresu wiedzy merytorycznej z bardzo wielu obszarów - medycyny, farmacji, chemii, biznesu, prawa, logistyki, psychologii i wielu innych. Wszelkie występujące niedopatrzenia i trudności odbijają się wielkim echem w mediach, przez co stanowią bardzo duże zagrożenie dla wizerunku przedsiębiorstwa, a nawet całej branży. Co więcej, zapobiegnięcie temu w branży farmaceutycznej wydaje się szczególnie trudne, ponieważ w grę wchodzą olbrzymie pieniądze, ale przede wszystkim ludzkie życie i zdrowie.

W niniejszym artykule opisano wyniki badania, którego celem było określenie czynników mających wpływ na wizerunek branży farmaceutycznej, a także odpowiedź na pytanie: jaki wpływ ma prawo farmaceutyczne na wizerunek branży. 


\section{Wprowadzenie teoretyczne}

Wizerunkiem określany jest zestaw skojarzeń interesariuszy z danym przedsiębiorstwem, marką czy produktem (de Chernatony, 2003). Nie jest to jednak zestaw obiektywnych przesłanek odpowiadających za takie, a nie inne postrzeganie danej organizacji czy wyrobu, ale „złożona, zmysłowa, intelektualna interpretacja" cech postrzeganego obiektu. Percepcja ta oparta jest na wyobrażonych lub rzeczywistych przesłankach opartych na subiektywnych przekonaniach wrażeniach, uczuciach, ideach (Daszkiewicz i Wrona, 2014). Wizerunek jest czymś niezwykle istotnym, ponieważ jest on nierozerwalnie związany z reputacją oraz tożsamością przedsiębiorstwa czy marki (Kall, 2001). Ze względu na ograniczoną wiedzę interesariuszy jego budowanie polega przede wszystkim na eksponowaniu silnych stron marki (Blythe, 2002).

W literaturze można również napotkać stwierdzenia odnoszące się do celu stawianego działaniom wizerunkowym. Do głównych rezultatów, jakie przedsiębiorstwa mają uzyskać dzięki dążeniu do pozytywnej reputacji marki, zalicza się przede wszystkim zwiększanie wyników finansowych, poprzez zwiększenie sprzedaży i pozyskanie nowych klientów (Sun, Paswan i Tieslau, 2016).

Benoit, w swoich badaniach dowiódł, że zarówno politycy czy celebryci, jak i przedsiębiorstwa mają podobne sposoby radzenia sobie z kryzysowymi sytuacjami, które niszczą ich wizerunek. Zasadnicza różnica polega na zasobach majątkowych poszczególnych osób oraz na tym, że w przypadku przedsiębiorstw działania poprawiające reputację, mogą być ograniczane przez dział prawny (Maiorescu, 2016). Drugi z tych czynników ma szczególne znaczenie w przypadku omawianej w niniejszym artykule branży farmaceutycznej.

Ze względu na szereg przepisów prawnych regulujących działania branży farmaceutycznej można zauważyć wiele elementów wspólnych dla całej branży, a mogących się przekładać na wizerunek poszczególnych przedsiębiorstw. W tej sytuacji można mówić zatem o wizerunku branży, podobnie jak w innych przypadkach o wizerunku marki. W tym przypadku wspólnymi elementami charakterystycznymi dla marki i dla całej branży są m.in. reputacja (pomijając reklamy, zazwyczaj media wspominają o całej branży, rzadko o poszczególnych producentach leków), sposób reklamowania (bardzo ograniczany prawnie, zakaz promocji leków Rx do osób spoza ochrony zdrowia, ścisły nadzór prawno-medyczny nad każdym materiałem reklamowym, komunikat o zapoznaniu się z treścią ulotki lub konsultacją z lekarzem lub farmaceutą) oraz zespół wrażeń nabywców (producenci leków rzadko się reklamują, poza reklamą skierowaną do pracowników ochrony zdrowia, z podkreśleniem własnej nazwy, dlatego przeciętni nabywcy raczej kojarzą branże i poszczególne produkty) (Altkorn, 1999; Urbanek i Kosińska, 2002). 


\section{Ograniczenia prawne związane z reklamą wyrobów farmaceutycznych}

Prawo ściśle reguluje nie tylko sposoby promocji farmaceutyków, lecz także to kto może je reklamować. Nie mogą to być bowiem lekarze, gdyż jest to uważane za czyn nieuczciwej konkurencji i zabieg ten nie jest zgodny z kodeksem etyki lekarskiej. Zawód lekarza należy bowiem do zawodów zaufania publicznego i nie powinien być kojarzony z żadnym podmiotem działającym na rynku farmaceutycznym, ponieważ mógłby być wówczas posądzony o działanie wyłącznie na własną finansową korzyść, a nie dla dobra pacjenta. Podobne ograniczenia prawne dotyczą także jego zawodowej aktywności. Wszelkie informacje o prowadzonej przez lekarza działalności także muszą być pozbawione treści, które mogą być uznane za reklamę. Dozwolone jest jednak publikowanie treści o charakterze informacyjnym lub poradnikowym, jak np. strona internetowa $\mathrm{z}$ blogiem branżowym, publikacja artykułów w czasopismach branżowych, udzielanie wywiadów pozbawionych znamion czy posiadanie szyldu w miejscu prowadzenia działalności. Wyżej wymienione kanały informacji mogą zawierać dane o prowadzonej działalności, kwalifikacjach, tytułach naukowych lub innych, dodatkowych umiejętnościach, jak np. znajomość języków obcych (Whitepress, 2016).

Rygorystyczne ograniczenia prawne dotyczą także pośredników w sprzedaży leków, czyli farmaceutów i aptekarzy. Mają oni bezwzględny zakaz obiecywania korzyści w zamian za zakup leku. Dozwolona jest natomiast reklama suplementów diety i produktów drogeryjnych, o ile dotyczy informacji i ich dostępności $\mathrm{w}$ aptece. Zakaz reklamy dotyczy także samych aptek i punktów aptecznych, a także prowadzonej przez nich działalności. Spod definicji reklamy ustawodawca wyłączył jednak takie dane, jak informacja o lokalizacji oraz godzinach otwarcia apteki czy punktu aptecznego (Ustawa z dn. 06.09.2001 r. - Prawo farmaceutyczne, Dz.U. $2008 \mathrm{Nr}$ 45, poz. 271 ze zm.).

Ustawodawca reguluje także kwestię tego, czym dokładnie jest reklama produktu leczniczego. Zgodnie z definicją przytoczoną przez Główny Inspektorat Farmaceutyczny, za reklamę uważa się wszelką działalność mającą na celu informowanie lub namawianie do używania konkretnego produktu leczniczego, a co za tym idzie wpływania na ilość przepisywanych recept czy wielkość sprzedaży. Stosowanymi środkami reklamy produktów leczniczych są takie zabiegi, jak:

- wizyty przedstawicieli handlowych lub medycznych u osób uprawnionych do wypisywania recept, a także $\mathrm{w}$ podmiotach uprawnionych 
do obrotu produktami leczniczymi, czyli aptekach i hurtowniach farmaceutycznych;

- dystrybucja próbek wyrobów leczniczych do pracowników służby zdrowia;

- finansowanie spotkań promocyjnych dla osób upoważnionych do wypisywania recept i sprzedaży wyrobów farmaceutycznych;

- finansowanie konferencji naukowych dla pracowników ochrony zdrowia;

- reklama środków spożywczych specjalnego przeznaczenia medycznego może się natomiast odbywać poprzez publikację wyników badań w pismach o charakterze naukowym lub popularnonaukowym (GIF, 2016).

Istotną informacją uregulowaną przez Główny Inspektorat Farmaceutyczny, jest też komunikat o tym kto może prowadzić działania reklamowe dla wyrobów leczniczych. Jedynymi osobami uprawnionymi do tego typu aktywności są podmioty odpowiedzialne za dane produkty i wszelkie konsekwencje wynikające $\mathrm{z}$ działania tych wyrobów lub też przez podmioty działające na zlecenie podmiotów odpowiedzialnych. Ponadto każdy z komunikatów, który adresowany jest do szerszego grona odbiorców, powinien być opatrzony następującą informacją: „Przed użyciem zapoznaj się z treścią ulotki dołączonej do opakowania bądź skonsultuj się z lekarzem lub farmaceutą, gdyż każdy lek niewłaściwie stosowany zagraża Twojemu życiu lub zdrowiu” (Rozporządzanie Ministra Zdrowia z dn. 21 listopada 2008 r., Dz.U. 2008 Nr 210, poz. 1327).

Wszystkie wyżej wymienione ograniczenia prawne sprawiają, że podmioty farmaceutyczne, w kontekście ściśle regulowanej działalności marketingowej, będą postrzegane przez finalnego nabywcę i potencjalnego finalnego nabywcę w bardzo podobny sposób. W tym kontekście należy zatem mówić o wizerunku branży, a nie wizerunku poszczególnych graczy na rynku wyrobów farmaceutycznych.

\section{Metody badania}

W niniejszym artykule zastosowano dwie metody badań - analizę najważniejszych przepisów prawa dotyczącego działalności biznesowej w branży farmaceutycznej oraz analizę opartą na wybranych artykułach internetowych dotyczących opinii o branży farmaceutycznej (przeanalizowanych zostało 12 artykułów).

Badanie polegało na przeanalizowaniu wizerunku branży farmaceutycznej na podstawie najwyżej pozycjonowanych w Internecie artykułów 
o tematyce postrzegania tej branży przez polskie społeczeństwo. Znacznym ograniczeniem tego badania jest mała ilość przytoczonych artykułów oraz fakt, że część z nich została przygotowana na zlecenia podmiotów z branży. Tak przygotowane artykuły mogą nieco zafałszowywać rzeczywistość, mimo iż zostały przeprowadzone przez wyspecjalizowane podmioty zajmujące się badaniami rynkowymi.

Celem niniejszego badania było określenie czynników mających wpływ na wizerunek branży farmaceutycznej, a także odpowiedź na pytanie: jaki wpływ ma prawo farmaceutyczne na wizerunek branży. Głównymi problemami badawczymi były natomiast odpowiedzi na następujące pytania:

- jak przepisy prawa związane z działalnością branży farmaceutycznej wpływają na wizerunek tego typu organizacji;

- w jaki sposób etyka działalności tej branży wpływa na jej wizerunek;

- jakie inne czynniki mogą mieć wpływ na wizerunek branży farmaceutycznej w polskim Internecie?

\section{Wyniki badań}

$\mathrm{Z}$ analizy artykułów internetowych wynika, że wobec branży farmaceutycznej stawiane są takie zarzuty, jak agresywny lobbing, brak transparentności i nieetyczne metody reklamy. Z czego można wywnioskować, że przedstawicielom tej branży nie przypisuje się pozytywnych intencji, a podejrzewa, że dla zysku są w stanie zrobić wszystko.

Taki wizerunek branży wiąże się z licznymi problemami, które pojawiły się w latach 80. i 90. XX w., kiedy to panowała w farmacji tendencja do „specjalnego traktowania”, np. lekarzy przepisujących recepty na produkty danej firmy, oraz obowiązywała „powinność wdzięczności”, czyli oferowanie korzyści majątkowych w zamian za zapewnienie sprzedaży danego wyrobu. Wizerunek ten obecnie może jednak zostać uznany za stereotypowy, zbudowany bowiem na doświadczeniach sprzed 20-30 lat.

Obecnie dominują trzy główne skojarzenia. Wiążą się one głównie z przekonaniem o bogactwie koncernów farmaceutycznych zbudowanym na cudzym nieszczęściu. Nieszczęście to zostało wskazane w analizowanych artykułach jako jedno z głównych źródeł dochodu. Do źródła zysków zostały również zaliczone działania korupcyjne, z którymi w dalszym ciągu, jak wynika $\mathrm{z}$ analizy artykułów, kojarzona jest farmacja.

Ponadto branża farmaceutyczna opisywana jest jako bardzo istotny element gospodarki, oddziałujący na tak ważne elementy ludzkiego życia, jak zdrowie i pieniądze. Uznawana jest także przez społeczeństwo za źródło 
wiedzy, ponieważ przedsiębiorstwa działające w tym obszarze ciągle muszą przeprowadzać badania naukowe, aby się rozwijać. Z kolei pozyskiwana wiedza stosowana jest ze względu na wiarę w możliwość poprawy jakości życia, przywrócenie prawidłowego funkcjonowania organizmu, a co za tym idzie - także w możliwość wydłużenia życia.

Poszukiwanie sposobów poprawy jakości życia oraz jego wydłużania, a także chęć maksymalizacji zysków to dwa główne, a w dodatku nieco sprzeczne cele branży farmaceutycznej. Każdy błąd, jaki powstanie w trakcie produkcji leków, a także każdy ze sposobów służących zwiększeniu zysków wywołują konsekwencje się dla podmiotu, który popełnił błąd, ale również w znacznym stopniu skutkują pogorszeniem wizerunku całej branży zarówno w kraju, jak i za granicą (choćby za sprawą importu). Dosyć często zdarza się, że społeczeństwo zaczyna też zastanawiać się czy niektóre, mocno nagłośnione $\mathrm{w}$ mediach, epidemie (np. A/H1N1) lub problemy zdrowotne dotykające bardzo małego odsetka populacji nie są takimi celowymi działaniami mającymi przynieść znaczny wzrost dochodów branży. Mówi się wówczas o tzw. zmowach producentów. Takie przypadki najlepiej obrazują uzasadnienie badania wizerunku w kontekście całej branży, a nie pojedynczych producentów. Ponadto, przedsiębiorstwa farmaceutyczne posądzane są o nadmierne wykorzystywanie środków przeznaczonych przez NFZ na leczenie pacjentów. Wszystko to sprawia, że w mediach niejednokrotnie pojawia się bardzo negatywny wizerunek tego segmentu.

Farmacja postrzegana jest pozytywnie przez pracowników, ze względu na systemy motywacyjne i premiowe, a także stwarzanie możliwości rozwoju przez pracodawców. Jak wskazują informacje zawarte w analizowanych artykułach, producenci leków są pracodawcami oferującymi bardzo dobre wynagrodzenia oraz liczne bonusy, jak np. telefon, samochód służbowy, finansowanie posiłków do określonego budżetu.

Pozytywne skojarzenia, oprócz kwestii wynagrodzeń, są spowodowane działaniami specjalistów od public relations oraz społecznej odpowiedzialności biznesu. Specjaliści ci tworzą wizerunek tzw. przyjaznych koncernów. Zabieg ten polega na angażowaniu się koncernów farmaceutycznych w sprawy społeczne za pomocą np. kampanii edukacyjnych czy badań profilaktycznych (wśród głośnych akcji promujących badania profilaktyczne znalazły się np. „Servier w trosce o żyły”, „Odnaleźć siebie” Adamedu, „MAM HAKA NA RAKA" GSK).

Są jednak tacy, którzy wśród wielu pozytywnych opinii, odnoszących się do wsparcia udzielanego przez branżę farmaceutyczną innym instytucjom i akcjom charytatywnym, a także podejmowania inicjatyw społecznych oraz wspierania stowarzyszeń pacjentów, doszukują się kontrowersyjnych, a nawet nieuczciwych działań marketingowych. Ci krytycy działań 
przedsiębiorstw z branży farmaceutycznej uważają, że wytwórcy leków są w swych dążeniach do maksymalizacji zysku na tyle bezwzględni, że działają według zasady „wszystko jest dozwolone”.

Argumentem nie do podważenia dla przeciwników farmacji są wartości głoszone przez producentów leków. Najważniejsza z nich głosi, że zdrowie jest najwyższą wartością, o którą bezustannie trzeba dbać, chronić oraz reagować na jej potrzeby i problemy. Stąd w branży farmaceutycznej przypisuje się duże znaczenie badaniom i rozwojowi. To właśnie dzięki nim następuje ciągły, dynamiczny postęp w medycynie, przekładający się na poprawę zdrowia i zwiększenie średniej długości życia. Dzięki tym badaniom podjęto też próby leczenia chorób uważanych za nieuleczalne. Przykładem takich chorób mogą być np. nowotwory, które w ujęciu współczesnej medycyny badane są pod kontem możliwości farmakoterapii, podobnej jak w przypadku chorób przewlekłych. Farmacja jest zatem uważana za branżę wnoszącą znaczny wkład do nauki.

\section{Regulacje prawne źródłem lepszego wizerunku}

Analizując powyższą sytuacje, można zauważyć, że wiele negatywnych opinii o branży farmaceutycznej jest sprzecznych z regulacjami prawnymi. Dlatego też przepisy prawne pomagają sprzyjać utrzymywaniu przez branże pozytywnego wizerunku. Tworzą one szereg wewnętrznych regulacji, dotyczących każdego możliwego obszaru, na którym mogą wystąpić nieprawidłowości skutkujące łamaniem prawa lub niszczeniem wizerunku. Do najbardziej regulowanych obszarów należą badania, promocja, refundacja oraz rejestracja leków.

Wszelkie przepisy prawne i wewnętrzne, do jakich dostosowują się przedsiębiorstwa z branży farmaceutycznej służą ostatecznie budowie zaufania społecznego i budowaniu społecznej odpowiedzialności biznesu.

\section{Oczekiwania społeczeństwa względem branży farmaceutycznej}

Społeczeństwo komunikuje swoje oczekiwania wobec producentów leków poprzez szeroko rozumiane media. W związku z sukcesywnym pojawianiem się tego typu komunikatów część $\mathrm{z}$ tych producentów podjęła się już ich spełnienia. Jeśli tendencja ta się utrzyma, to zwiększy się pozytywne 
nastawienie do tej branży. Wśród oczekiwań stawianych przez społeczeństwo znalazły się przede wszystkim:

- dostęp do wiedzy o przeznaczeniu pieniędzy - jest on uzasadniony tym, że część z tych pieniędzy pochodzi z pieniędzy publicznych, a dodatkowo istnieje ryzyko zachowań korupcyjnych; w celu uwiarygodnienia legalności wydawania pieniędzy, niektórzy producenci leków podjęli się publikacji zarobków lekarzy;

- odpowiedzialność - jest ona wynikiem pozycji, jaką branża farmaceutyczna zajmuje na rynku; do branży tej bowiem należy wzięcie odpowiedzialności za ludzkie zdrowie i życie;

- dialog - społeczeństwo oczekuje od branży farmaceutycznej, że będzie ona prowadzić dialog pomiędzy nim a pracownikami ochrony zdrowia;

- dostęp do innowacyjnych leków - społeczeństwo chce być leczone innowacyjnymi lekami, ale niestety rzadko są one zapewniane przez polskich producentów.

\section{Podsumowanie}

Sama branża farmaceutyczna podkreśla znaczny wpływ prawa farmaceutycznego na swój wizerunek. Wizerunek ten jest nieco niejednolity, gdyż to, co z jednej strony świadczy pozytywnie o branży, może jednocześnie świadczyć o niej negatywnie. Jedyną cechą, u której nie zaobserwowano negatywnych opinii na temat tej branży, to wysokie zarobki oraz bogaty pakiet socjalny.

Zestawienie ze sobą wyników wyżej wymienionych badań pozwoliło na wstępne scharakteryzowanie wizerunku branży farmaceutycznej w polskim Internecie oraz określenie czynników wpływających na jej wizerunek. Można powiedzieć, że przemysł farmaceutyczny jest kojarzony przede wszystkim ze stereotypowymi przekonaniami o szerzącej się na olbrzymią skalę korupcji oraz z obrotem dużymi sumami pieniędzy. Jeśli chodzi zaś o pozytywne poglądy dotyczące tego segmentu, to istnieje przekonanie o charakterystycznych dla niego bardzo dobrych warunkach pracy oraz tworzeniu mocno rozbudowanych i efektywnych działów odpowiedzialnych za badania i rozwój. Nie jest to jednak obraz kompletny i obiektywny, gdyż jest bardzo zależny od wyników pozycjonowania w Internecie, na które przedsiębiorstwa $\mathrm{z}$ branży farmaceutycznej mogą wywierać znaczący wpływ. W celu rozwinięcia badań nad tą tematyką należałoby przeprowadzić badania jakościowe (np. wywiady) lub ilościowe (np. ankiety) na niezależnych, a także powiązanych podmiotach (np. pracownikach ochrony zdrowia). 


\section{Bibliografia}

Altkorn, J. (1999). Strategia marki. Warszawa: PWE.

Blythe, J. (2002). Komunikacja marketingowa. Warszawa: PWE.

Daszkiewicz, M. i Wrona, S. (2014). Kreowanie marki korporacyjnej. Warszawa: Difin.

de Chernatony, L. (2003). Marka. Wizja i tworzenie marki. Gdańsk: Gdańskie Wydawnictwo Psychologiczne.

Gazeta Wyborcza/RMF FM/Rynek Zdrowia. (2010). Ogłoszenie pandemii A/H1N1: zmowa WHO i koncernów farmaceutycznych?. Pozyskano z: www.rynekzdrowia.pl (12.04.2017).

GIF. (2016). Reklama produktów leczniczych. Warszawa: Główny Inspektorat Farmaceutyczny. Pozyskano z: https://www.gif.gov.pl/pl/nadzor/reklama-produktow-leczn/476,Reklamaproduktow-leczniczych.html (22.05.2016)

GSK. (2011). Na czym polega odpowiedzialność firmy farmaceutycznej?. Raport Społeczny GlaxoSmithKline Pharmaceuticals 2009-2010. Warszawa: GlaxoSmithKline Pharmaceuticals. Pozyskano z: https://www.gsk.com.pl/Layout/pdf/GSK_CSR.pdf (12.04.2017).

Kall, J. (2001). Silna marka. Istota i kreowanie. Warszawa: PWE.

Koniec spektakularnych wzrostów na rynku leków na receptę, Pozyskano z: www.pmrpublications.com, (12.04.2017)

Lizut, M. (2006). Tajemnice firmy farmaceutycznej Roche: szkolenia z manipulowania lekarzami. Pozyskano z: www.gazeta.pl (12.04.2017).

Maiorescu, R.D. (2016). Deutsche telekom's spying scandal: An international application of the image repair discourse. Public Relations Review, 42(4).

PAP/Rynek Zdrowia. (2008). Korupcja w służbie zdrowia: kolejne zatrzymania. Pozyskano Z: www.rynekzdrowia.pl (12.04.2017).

Ponad dwie trzecie Polaków (69\%) życzyłoby sobie w Nowym Roku (2008) przede wszystkim zdrowia (2008), Pozyskano z: www.egospodarka.pl , (12.04.2017)

Rozporządzenie Ministra Zdrowia z dnia 21 listopada 2008 r. w sprawie reklamy produktów leczniczych (Dz.U. 2008 Nr 210, poz. 1327). Pozyskano z: http://isap.sejm.gov.pl/DetailsServlet?id=WDU20082101327 (14.04.2017).

Sałamacha, I. (2010). Wizerunek firm farmaceutycznych $w$ Polsce. Pozyskano z: http://www. proto.pl/artykuly/wizerunek-firm-farmaceutycznych-w-polsce (12.04.2017).

Sun, Q., Paswan, A. K. i Tieslau, M. (2016). Country resources, country image, and exports: Country branding and international marketing implications. Journal of Global Marketing, 29(4).

Szwajcarski Roche da 300 miejsc pracy, Pozyskano z: www.gazeta.pl, (12.04.2017)

Urbanek, G. i Kosińska E. (red.). (2002). Zarządzanie marka. Warszawa: PWE.

Ustawa z dnia 6 września 2001 r. - Prawo farmaceutyczne (Dz.U. 2008 Nr 45, poz. 271 ze zm.). Pozyskano z: http://isap.sejm.gov.pl/DetailsServlet?id=WDU20011261381 (14.04.2017)

Whitepress. (2014). Ograniczenia prawne w content marketingu i reklamie. Pozyskano z: https:// www.whitepress.pl/baza-wiedzy/47/ograniczenia-prawne-w-content-marketingu-ireklamie (12.04.2017).

Wyniki kontroli CBA i 'taśmy prawdy' pogrą̇ą Piechę? (2008). Pozyskano z: www.rynekzdrowia. pl, (12.04.2017)

Zwalniaja już firmy farmaceutyczne, Pozyskano z: www.tvn24.pl , (12.04.2017) 

